Vinicius Navarro Morende

Plantar alimento ou combustível? Formação territorial no sertão baiano

São Paulo

2013 
Vinicius Navarro Morende

\title{
Plantar alimento ou combustível? Formação territorial no sertão baiano
}

\author{
Versão corrigida da dissertação apresentada à \\ Escola de Artes, Ciências e Humanidades da \\ Universidade de São Paulo para obtenção do \\ título de Mestre em Ciências. \\ Área de Concentração: Mudança Social e \\ Participação Política \\ Orientador: Prof. Dr. Sidnei Raimundo
}

São Paulo

2013 
Autorizo a reprodução e divulgação total ou parcial deste trabalho, por qualquer meio convencional ou eletrônico, para fins de estudo e pesquisa, desde que citada a fonte.

\section{CATALOGAÇÃO-NA-PUBLICAÇÃO}

Biblioteca

Escola de Artes, Ciências e Humanidades da Universidade de São Paulo

Morende, Vinicius Navarro

Plantar alimento ou combustível?: formação territorial no sertão baiano / Vinicius Navarro Morende ; orientador, Sidnei Raimundo. - São Paulo, 2013.

185 f. : il.

Dissertação (Mestrado em Ciências) - Programa de PósGraduação em Mudança Social e Participação Política, Escola de Artes, Ciências e Humanidades da Universidade de São Paulo.

Versão corrigida.

1. Biocombustíveis. 2. Biocombustíveis - Aspectos econômicos - Aspectos sociais - Bahia. 3. Agricultura familiar. 4. Política pública - Brasil. 5. Desenvolvimento econômico regional. I. Raimundo, Sidnei, orient. II. Título.

CDD 22.ed. -662.88 
Nome: MORENDE, Vinicius Navarro

Título: Plantar alimento ou combustível? Formação territorial no sertão baiano

Dissertação apresentada à Escola de Artes, Ciências e Humanidades da Universidade de São Paulo para obtenção do título de Mestre em Ciências.

Aprovado em:

Banca Examinadora

Prof. Dr. Instituição:

Julgamento: Assinatura:

Prof. Dr. Instituição:

Julgamento: Assinatura:

Prof. Dr. Instituição:

Julgamento: Assinatura: 


\section{Resumo}

Esta pesquisa busca analisar as contradições existentes no incentivo do poder público federal brasileiro à produção de alimentos e à produção de biodiesel no espaço do sertão baiano. Para tanto, foram analisados os efeitos do Programa Nacional de Uso e Produção do Biodiesel (PNPB) e do Programa de Aquisição de Alimentos (PAA) para a formação territorial do município de Morro do Chapéu (BA), especialmente, durante o período entre 2007 e 2012. O trabalho utilizou o apoio metodológico da história oral, por meio da sistematização de entrevistas realizadas com agricultores familiares que participaram das atividades dos programas. $\mathrm{O}$ aumento do emprego e da renda familiar dos pequenos produtores rurais e a conseqüente intensificação da base técnica em localidades do município são alguns dos resultados da ação pública federal e da organização produtiva e social local. No entanto, uma série de evidências mostra os desafios do desenvolvimento de programas públicos e da agricultura familiar no Brasil.

Palavras-chave: políticas públicas; agricultura familiar; biocombustíveis 


\section{Abstract}

This research intends to analyze the existing contractions in the incentive of brazilian federal public power to the food production and to the production of biodiesel to the space of Bahia's State dry lands. For that, the effects of the National Program of Production and Use of Biodiesel (PNPB) and the brazilian Program of Food Acquisition (PAA) to the territorial formation of the Morro do Chapéu (BA) city were analyzed, specially, during the period between 2007 and 2012. The work is based on the oral history methodology made through a series of interviews with family farmers that participated of the activities of both programs. The rising of employment and familiar incomes of family farmers and the intensification of technical basis in localities of the municipality are some results of the federal public action and the local productive and social organization. However, a series of evidences present the challenges to the public programs development and to development of family farm in Brazil.

Keywords: public policy; family farming; biofuel 


\section{Lista de figuras}

Figura 1: Mapa de localização do município de Morro do Chapéu (BA) 2

Figura 2: Mapa de situação do município de Morro do Chapéu (BA)

Figura 3: Mapa planimétrico de Morro do Chapéu (BA) e localidades analisadas

Figura 1.2.1: Rua Coronel Souza Benta, em Morro do Chapéu (BA)

Figura 2.1.1: Vista do povoado de Fedegosos, em Morro do Chapéu. (BA) 48

\begin{tabular}{ll}
\hline Figura 2.1.2: Domingo de feira no povoado de Fedegosos & 48 \\
\hline
\end{tabular}

Figura 2.1.3: Praça da igreja matriz do povoado do Icó, em Morro do Chapéu (BA) 49

Figura 2.1.4: Residências alinhadas a partir da igreja matriz, no Icó $\quad 49$

Figura 2.1.5: Ilustração dos limites de Morro do Chapéu e da área da antiga freguesia $\quad 51$

Figura 2.1.6: Relação da ocupação espacial da mamona no Brasil e no Nordeste $\quad 53$

Figura 2.1.7: Agricultor, Rosemiro José da Silva, do povoado do Icó $\quad 57$

\begin{tabular}{ll}
\hline Figura 2.2.1: Propriedade de Rosemiro José da Silva & 62 \\
\hline
\end{tabular}

\begin{tabular}{lll}
\hline Figura 2.3.1: Ocupação de culturas agrícolas tradicionais na Bahia e perdas na produção & 66
\end{tabular}

\begin{tabular}{ll}
\hline Figura 2.3.2: Evolução da ocupação da soja na Bahia & 67
\end{tabular}

\begin{tabular}{lc}
\hline Figura 2.3.3: Evolução da produção de soja na Bahia & 67 \\
\hline
\end{tabular}

\begin{tabular}{ll}
\hline Figura 2.3.4: Evolução da produtividade da soja na Bahia & 68 \\
\hline
\end{tabular}

Figura 2.3.5: Evolução da ocupação da mamona na Bahia 68

Figura 2.3.6: Evolução da produção da mamona na Bahia $\quad 68$

\begin{tabular}{ll}
\hline Figura 2.3.7: Evolução da produtividade da mamona na Bahia & 69
\end{tabular}

\begin{tabular}{ll}
\hline Figura 2.3.8: Malha rodoviária estadual e federal em Morro do Chapéu (BA) & 72 \\
\hline
\end{tabular}

\begin{tabular}{lr}
\hline Figura 3.1: Vila do Ventura, em Morro do Chapéu (BA) & 80 \\
\hline
\end{tabular}

Figura 4.2.1: Agricultor, José Barbosa de Jesus, na propriedade no Icó 127

Figura 4.2.2: Armazéns da associação de moradores da Malhada de Areia, em Morro do 131

Chapéu (BA)

Figura 4.4.1: Forno de barro da agricultora Maria Aparecida Leite Cardoso, em 138

Fedegosos

Figura 4.4.2: Merendeira em Fedegosos, Simone dos Santos Souza 139

Figura 4.4.3: Agricultor, Jaílson Rosa Rodrigues, na Malhada de Areia 140

Figura 4.4.4: Agricultor, Florisvaldo Bispo Souza, na Malhada de Areia 142

Figura 4.5.1: Área do estacionamento da feira livre de Morro do Chapéu (BA) 144

Figura 4.5.2: Barragem do Angelim, em Morro do Chapéu (BA), em 07/2011 e 02/2012 150

Figura 4.6.1: Vista panorâmica de propriedade rural no povoado do Velame, em Morro 152 do Chapéu (BA)

Figura 4.6.2: Remanescente quilombola, Luciano Bernardo de Brito, do Velame 153

Figura 4.7.1: Barbearia do agricultor João Medeiros da Silva, em Fedegosos 159

Figura 4.7.2: Poço artesiano irregular na proximidade do PEMC 163 


\section{Lista de abreviaturas}

\begin{tabular}{|c|c|}
\hline APPC & Associação dos Pequenos Produtores da Chapada Diamantina \\
\hline Bioconfe & Conferência Nacional de Bioenergia \\
\hline Conab & Companhia Nacional de Abastecimento \\
\hline Coopaf & $\begin{array}{l}\text { Cooperativa de Produção e Comercialização da Agricultura Familiar do } \\
\text { Estado da Bahia }\end{array}$ \\
\hline CPRM & Serviço Geológico do Brasil \\
\hline DAP & Declaração de Aptidão ao Pronaf \\
\hline EBDA & Empresa Baiana de Desenvolvimento Agrário \\
\hline Embrapa & Empresa Brasileira de Pesquisa Agropecuária \\
\hline Fetag-BA & $\begin{array}{l}\text { Federação dos Trabalhadores da Agricultora Familiar do Estado da } \\
\text { Bahia }\end{array}$ \\
\hline IBGE & Instituto Brasileiro de Geografia e Estatística \\
\hline INSS & Instituto Nacional de Seguridade Social \\
\hline PAA & Programa de Aquisição de Alimentos \\
\hline PBio & Petrobras Biocombustíveis \\
\hline PCdoB & Partido Comunista do Brasil \\
\hline PEMC & Parque Estadual de Morro do Chapéu \\
\hline PGPAF & $\begin{array}{l}\text { Programa de Garantia do Preço Mínimo para os Produtos da } \\
\text { Agricultura Familiar }\end{array}$ \\
\hline PIB & Produto Interno Bruto \\
\hline PL & Partido Liberal \\
\hline PNAE & Programa Nacional de Alimentação Escolar \\
\hline PNPB & Programa Nacional de Uso e Produção do Biodiesel \\
\hline PP & Partido Progressista \\
\hline Pró-Álcool & Programa Nacional do Álcool \\
\hline PSD & Partido Social Democrático \\
\hline Pronaf & Programa Nacional de Fortalecimento da Agricultura Familiar \\
\hline PT & Partido dos Trabalhadores \\
\hline PTB & Partido Trabalhista Brasileiro \\
\hline Sidra-IBGE & Sistema IBGE de Recuperação Automática \\
\hline Sudene & Superintendência do Desenvolvimento do Nordeste \\
\hline STR-MC & Sindicato dos Trabalhadores Rurais de Morro do Chapéu \\
\hline $\mathrm{UCs}$ & Unidades de Conservação \\
\hline UDN & União Democrática Nacional \\
\hline UJS & União da Juventude Socialista \\
\hline
\end{tabular}




\section{Sumário}

Lista de figuras $\quad$ V

Lista de abreviaturas $\quad$ VI

Introdução

1 Energia e alimentos 9

1.1 - Valorização do espaço e do território . . . . . . . . . . . . . . . . . . . . 12

1.2 - Ocupação sertaneja e geografia política . . . . . . . . . . . . . . . 22

1.3. - Matriz energética global e formação territorial . . . . . . . . . . . . . 30

1.4 - Adoção das escalas e território . . . . . . . . . . . . . . 35

2 Formação territorial em Morro do Chapéu 39

2.1 - Organização dos territórios-rede no município . . . . . . . . . . . . . 46

2.2 - Agricultura familiar no município . . . . . . . . . . . . 58

2.3 - PAA e ampliação da infraestrutura . . . . . . . . . . . . . . . . . 63

3 Alterações na estrutura de poder $\quad 75$

3.1 - Alinhamento local com escalas estadual e federal . . . . . . . . . . . . . 89

3.2 - Política da mamona e o controle sobre fluxos . . . . . . . . . . 96

3.3 - Coopaf e emergência de um novo grupo político . . . . . . . . . . . . . . 100

3.4 - Espaço e uso da informação na escala local . . . . . . . . . . . . . . . . . . . 111 
4.1 - Mudanças para as formas da zona rural . . . . . . . . . . . . . . 118

4.2 - Superação da perda da mamona nos terreiros . . . . . . . . . . . . . 125

4.3 - Interrupção de contrato e declínio de preços . . . . . . . . . . . . . . . . 132

4.4 - PAA e alteração nos preços dos alimentos . . . . . . . . . . . . . . . 136

4.5 - Aumento dos fluxos entre zona rural e sede . . . . . . . . . . . . . . . . . 144

4.6 - Mecanização e intensificação técnica . . . . . . . . . . . . . . . . . . . 150

4.7 - Subsistência e perspectivas em Morro do Chapéu . . . . . . . . . . . . . . . 157 


\section{Introdução}

Numa análise econômica neoliberal, a expansão do consumo global e a necessidade da geração de volumes cada vez maiores de energia desafiam governos a garantir o abastecimento da demanda a fim de não colocarem em risco o crescimento econômico dos países. Na busca por novas fontes viáveis de energia, variados fatores favoreceram a participação daquelas ditas renováveis dentro das matrizes energéticas de algumas nações. No entanto, fontes como os biocombustíveis, produzidos a partir de culturas agrícolas, trouxeram à tona a questão do uso da terra para a produção de alimentos - geração de energia destinada ao consumo humano - ou para a produção de biomassa - a fim de suprir equipamentos e máquinas.

Dentro desta problemática, este estudo procura analisar as contradições existentes no incentivo do poder público federal brasileiro, um ator importante para a configuração territorial interna e regional, à produção de alimentos e à produção de biodiesel. No caso, as contradições foram evidenciadas no espaço de Morro do Chapéu, município baiano localizado entre a Chapada Diamantina e os sertões do rio São Francisco (Figuras 1 e 2). As dinâmicas promovidas por programas públicos de apoio à produção de alimentos e de biodiesel em diversas localidades subsidiaram a análise. 


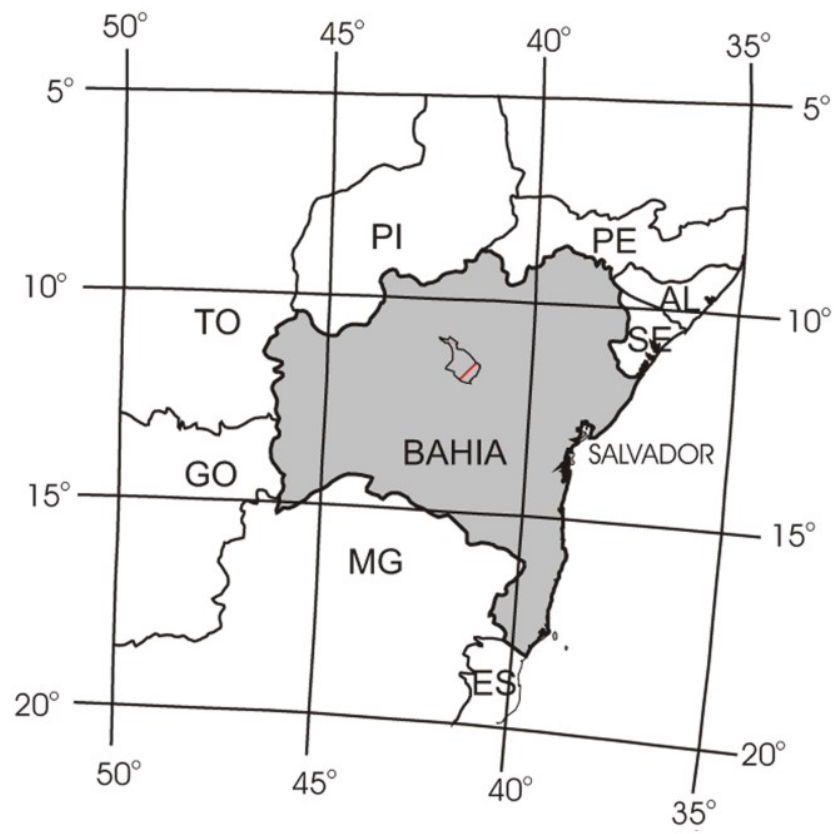

LEGENDA

Limites de Morro do Chapéu

ESCALA $1: 160.000 .000$

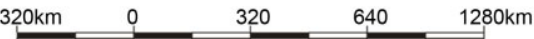

Figura 1 - Mapa de localização do município de Morro do Chapéu (BA). Fonte: ROCHA, COSTA, $1995 \mathrm{a}$.

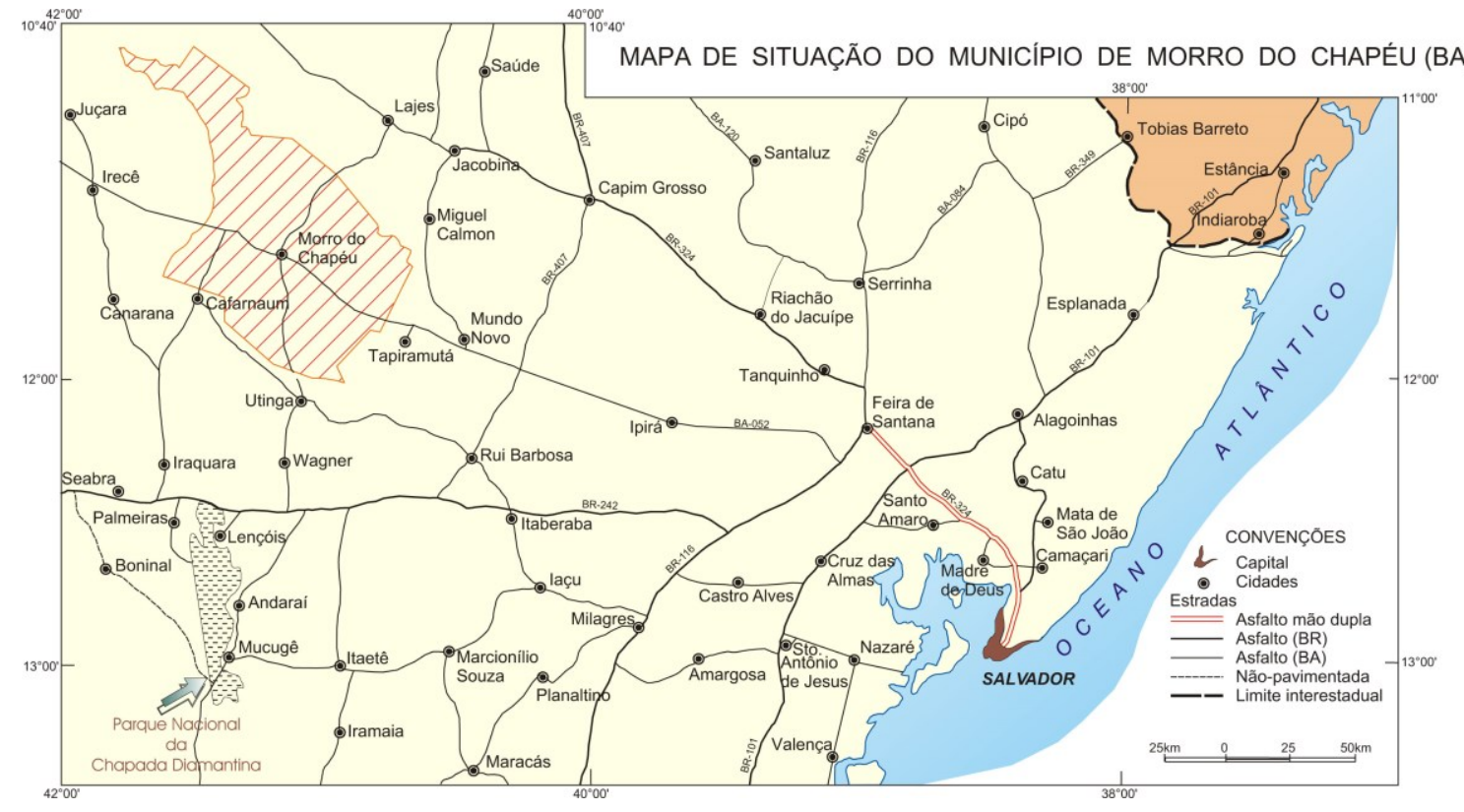

Figura 2 - Mapa de situação do município de Morro do Chapéu (BA). Fonte: ROCHA, COSTA, 1995a.

Entre as localidades analisadas estão a sede do município e os povoados de Malhada de Areia, Velame, Icó e Fedegosos (Figura 3). As mudanças de ordem econômica, política e social foram ressaltadas. Estas dinâmicas foram consideradas, 
principalmente, no período entre os anos de 2007 e 2012, durante um processo no qual a influência das atividades ocorreu com maior intensidade no local.
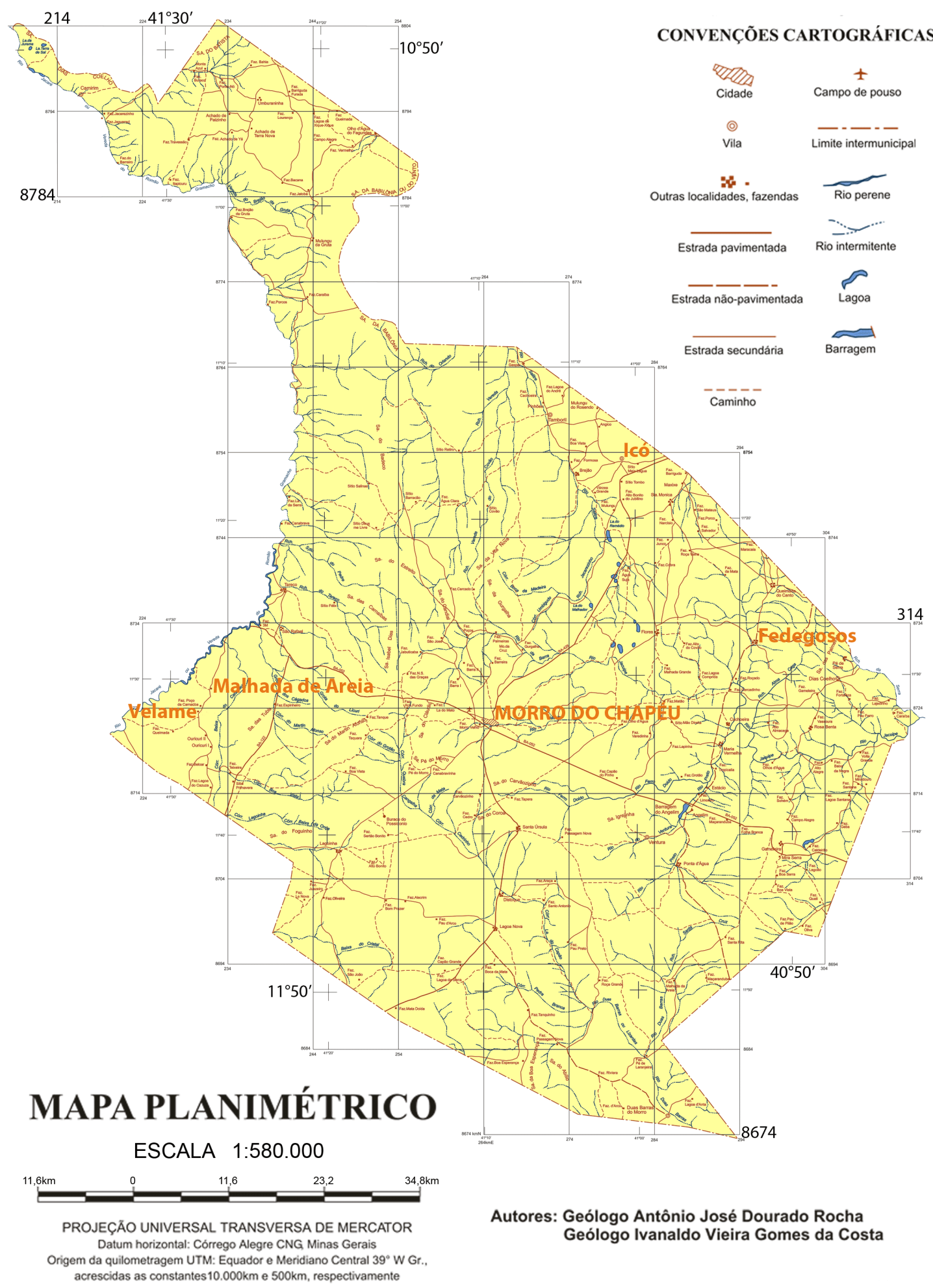

Autores: Geólogo Antônio José Dourado Rocha Geólogo Ivanaldo Vieira Gomes da Costa

Figura 3 - Mapa planimétrico de Morro do Chapéu (BA) com destaque para as localidades analisadas. Fonte: ROCHA, COSTA, 1995b. 
A escolha da área de análise se deu porque Morro do Chapéu integra a principal região produtora de mamona do Brasil. Esta área chegou a ser responsável pela maior parte da produção global da cultura durante algum tempo do século XX. Apesar deste período não ter deixado evidências na cidade na forma de obras ou construções, a mamona se tornou um dos símbolos do favorecimento da agricultura familiar nordestina no lançamento do Programa Nacional de Produção e Uso do Biodiesel (PNPB).

A sede da Cooperativa de Produção e Comercialização da Agricultura Familiar do Estado da Bahia (Coopaf), uma das principais cooperativas voltadas para a comercialização de produtos dos pequenos produtores da região, também está localizada em Morro do Chapéu. A organização foi criada entre 2005 e 2006. Além de atuar na cadeia de biodiesel, por meio da comercialização da mamona no município e em diversas cidades da região, a Coopaf também executou atividades do Programa de Aquisição de Alimentos (PAA).

A atuação da cooperativa a partir de ambos os programas públicos federais permitiu a comparação das contradições do incentivo à produção de biocombustíveis e de alimentos na escala local. Para tanto, parte-se do pressuposto de que as mudanças ocorridas por conta do PNPB e o PAA contribuíram para que ocorressem alterações na estrutura social e política do município e nas funções econômicas e formas geográficas de diversas localidades, promovendo novas dinâmicas para a formação territorial de Morro do Chapéu.

A metodologia da história oral foi utilizada visando organizar as informações necessárias à comprovação da hipótese, disponíveis em sua maioria na experiência de agricultores e profissionais envolvidos com o tema da pesquisa. A expectativa era que a sistematização de uma série de entrevistas realizadas ao longo de um período de dois anos no município com estes atores contribuísse para revelar aspectos da formação territorial do município.

Optou-se pelo apoio da história oral temática, mais próxima das entrevistas tradicionais (MEIHY, 2007, p. 39), para obter informações relativas ao processo ocorrido entre 2007 e 2012, enquanto que para o levantamento de aspectos históricos sobre as localidades utilizou-se a história oral de vida. As entrevistas dependeram da documentação previamente apurada e mantiveram vínculos com esta para o auxílio probatório da hipótese. No caso da história oral de vida, a questão subjetiva se tornou essencial, admitindo-se fantasias, omissões e distorções, já que os relatos dependiam da 
memória. "Em termos sociomorais, a história oral tem vocação a valorizar o indivíduo em detrimento do exclusivismo da estrutura social” (MEIHY, 2007, p. 37).

Consideram-se como elementos constitutivos da memória, seja ela individual ou coletiva, os acontecimentos vividos pessoalmente e os acontecimentos vividos "por tabela" e o fato da memória ser seletiva (POLACK, 1992, p. 203). Assim, também parte-se do princípio de que "se a memória é socialmente construída, é óbvio que toda documentação também o é [e de que] não há diferença fundamental entre a fonte escrita e fonte oral" (POLACK, 1992, p. 207).

Assim, a utilização da história oral foi a forma escolhida para favorecer a produção de documentos que atendam ao imediatismo dos efeitos e a rapidez com que as mudanças afetaram o espaço analisado. O que garantiu unidade e coerência às entrevistas enfeixadas em um mesmo conjunto foi "a repetição de certos fatores que, por fim, caracteriza a memória coletiva" (MEIHY, 2007, p. 28). O cruzamento de informações similares e antagônicas entre os atores entrevistados fomentou a análise. Obviamente, o levantamento e a sistematização dos demais documentos apoiaram tanto a verificação de outros processos históricos ocorridos no município quanto a análise do processo em destaque.

A partir do conhecimento anterior à realização da pesquisa de atores envolvidos com o objeto de estudo por parte do pesquisador, foi realizada uma série de conversas com pessoas e profissionais, em Morro do Chapéu, para a escolha dos entrevistados e das localidades consideradas. Um roteiro de entrevista semi-estruturado com algumas temáticas de interesse a serem abordadas nos diálogos com os agricultores familiares e demais envolvidos com a realização dos programas públicos foi utilizado.

Após a realização das entrevistas foi feito o arquivamento dos materiais, a transcrição, a textualização e a transcriação dos conteúdos. Os entrevistados alfabetizados receberam uma cópia do texto da entrevista para a confirmação da veracidade do relato. No caso daqueles não letrados e mais idosos, a cópia final da entrevista foi entregue, lida, complementada por novos diálogos que foram registrados com recurso eletrônico.

A partir da sistematização das entrevistas, da documentação complementar e de dados estatísticos oficiais as informações foram associadas e consolidadas expondo um panorama das mudanças provocadas pelas ações do PAA e do PNPB na cidade baiana entre 2007 e 2012 e as contradições inerentes às iniciativas. Este conjunto de efeitos espaciais foi procedido da análise de outros processos econômicos, sociais e políticos 
que integram a formação territorial de Morro do Chapéu ao longo dos séculos e que marcam o processo de destaque na pesquisa.

É importante destacar os levantamentos e as análises realizadas a partir dos dados da produção agrícola municipal, do Instituto Brasileiro de Geografia e Estatística (IBGE), para complementar as informações colhidas em campo e dos resultados das urnas eleitorais, disponibilizados pelo Tribunal Superior Eleitoral (TSE), para verificar os efeitos políticos da atuação da Coopaf nas últimas eleições.

Dividido em quatro partes, este trabalho não tem a pretensão de esgotar a temática abordada, mas contribuir para a compreensão de parte do problema. A organização da base teórica na qual o estudo se apoiou e os métodos de pesquisa utilizados são apresentados no primeiro capítulo, no qual também é realizado o resgate histórico dos programas públicos analisados. A análise do processo de desenvolvimento do PNPB e do PAA e a avaliação dos efeitos produzidos em Morro do Chapéu são precedidas da elaboração de um panorama da matriz energética mundial, considerando disputas e conflitos por recursos naturais.

A caracterização de Morro do Chapéu é o foco do capítulo dois. Neste, o objetivo foi dar continuidade ao diálogo entre a base teórica, os métodos e os resultados obtidos na coleta de dados. O espaço considerado para o município foi dividido em duas áreas distintas: a zona rural e a sede, a área mais urbanizada de Morro do Chapéu.

O terceiro capítulo é dedicado à formação política em Morro do Chapéu e, para tanto, destaca alguns processos da evolução da estrutura política do município, entre eles, o coronelismo. O capítulo quatro trata especificamente do processo de formação territorial ocorrido em Morro do Chapéu a partir de 2007, por influência das ações do PAA e, principalmente, do PNPB.

A proposta do trabalho de analisar características da vida dos sertanejos é enriquecida pela visão daqueles que sofrem com as mais diversas necessidades e cuja existência serve, em partes, à perpetuação das desigualdades do sistema capitalista no Brasil. São famílias que vivem nas áreas rurais e que apenas recentemente começaram a ser atendidas por serviços públicos básicos, como a educação e a saúde. As iniciativas analisadas, talvez, façam parte do processo pelo qual muitos agricultores passaram da situação de miséria para a de pobreza. São mudanças que contribuem com aspectos importantes, como a segurança alimentar e o aumento da renda, e que, por outro lado, os inserem cada vez mais na sociedade do consumo. 
A análise das mudanças no território apresenta resultados importantes para verificar os efeitos provocados por programas públicos em geral e pelo mercado para a vida dos moradores da zona rural no Brasil. Assim é possível revelar tanto a coerência entre os discursos adotados pelos atores para justificar suas ações quanto a eficácia das iniciativas em proporcionar a melhoria das condições de vida dessas pessoas.

A formação territorial foi analisada a partir dos conceitos de espaço e território. Este é delimitado por uma série de fatores que, grosso modo, representam a evolução dos limites do município de Morro do Chapéu ao longo dos séculos, no sertão da Bahia. Embora as duas categorias geográficas sejam as balizadoras para apoiar o estudo, este teve apoio de dados históricos, sociológicos e antropológicos.

A vivência do pesquisador durante o ano de 2008 no município de Morro do Chapéu e no povoado de Mirorós, na região da Chapada Velha, as viagens realizadas pelo sertão na época e depois e o fato de ter conhecido uma série de habitantes da zona rural contribuíram diretamente para a escolha do tema da pesquisa e para a realização do trabalho. Os laços prévios estabelecidos com parte dos trabalhadores rurais da Coopaf favoreceram a adoção da postura de tentar analisar os efeitos dos objetos de pesquisa pelo ponto de vista da agricultura familiar, pequenos proprietários de terra e daqueles que trabalham pela conservação dos valores históricos e culturais.

Os anos de trabalho na imprensa sindical, pouco valorizada dentro da comunicação social, mas crucial para o desenvolvimento de análises críticas, contribuíram para a formulação de uma visão de mundo particular apoiada na existência de diferentes relações de poder. Em partes, isso facilitou o envolvimento com os atores ligados à Coopaf e, consequentemente, o acesso a informações privilegiadas e processos que se davam no município no qual se deu a pesquisa e que aconteceram enquanto o pesquisador não estava presente no lugar.

As incursões realizadas em Morro do Chapéu com o objetivo de apurar informações para o estudo se deram com o apoio financeiro da Coordenação de Aperfeiçoamento de Pessoal em Ensino Superior (Capes). A ajuda dos profissionais da cooperativa também se mostrou determinante para a obtenção dos resultados apurados. Até agora os conflitos resultantes do objeto da pesquisa estão, na maioria, ligados ao campo das lutas de classes, mas novas dinâmicas dadas na escala local permitem desdobrar a pesquisa em outros estudos a partir de sua conclusão.

Isso permitirá dar continuidade à análise das "veias abertas" das microrrelações de poder que se dão na escala local, riquíssimas para compreender como se dão os 
mecanismos que perpetuam a condição social, econômica e política do sertão nordestino. Este estudo é uma contribuição às lutas dos que batalham no dia-a-dia pela emergência de uma realidade menos desigual e contra atores poderosos que concentram riquezas e poder explorando a miséria humana pelo país. 


\section{Energia e alimentos: bases teóricas e metodológicas da pesquisa}

Antes de iniciar a análise das dinâmicas relacionadas aos programas públicos de incentivo à produção de alimentos e biocombustíveis no município de Morro do Chapéu, na Bahia, é importante considerar o contexto em que se inserem ambas as iniciativas. O PAA é compreendido como uma das ações de um dos primeiros programas implantados na gestão do ex-presidente Luiz Inácio da Silva, o Fome Zero.

Esta iniciativa teria começado com a criação do Conselho Nacional de Segurança Alimentar e Nutricional (Consea), em janeiro de 2003, referente a um pedido que aguardou dez anos até ser acatado, e do Ministério Extraordinário de Segurança Alimentar e Combate à Fome, no primeiro ato legislativo do governo Lula. Durante um seminário realizado ao final de 2003 o então ministro da pasta, José Graziano, afirmou que entre os objetivos do Fome Zero estava a garantia do "direito a todos os brasileiros de tomar café da manhã, almoçar e jantar”, numa iniciativa que envolvesse a participação social, e a realização de uma ação "emergencial" e "estrutural" (SILVA, 2004, p. 16).

O programa teria vindo para amenizar o fato de que mesmo o Brasil sendo um dos maiores produtores mundiais de alimentos, ainda possuía um grande contingente de miseráveis. No entanto, os responsáveis pela iniciativa reconheciam que

\footnotetext{
alcançar de fato a segurança alimentar no Brasil exige um modelo de desenvolvimento econômico que privilegie o crescimento com distribuição de renda, de modo a ampliar o mercado interno do país com geração de empregos, melhoria dos salários pagos e, mais especificamente, recuperação do poder aquisitivo do salário mínimo (SILVA, TAKAGI, 2004, p. 45).
}

Entre as diversas iniciativas que foram desenvolvidas a partir da criação do programa, esta pesquisa abordou especificamente o PAA. O programa, aliado ao Programa Nacional de Alimentação Escolar (PNAE), favorece a compra de alimentos e produtos da região onde serão consumidos, em geral, por escolas públicas, nas merendas aos alunos, e para entidades filantrópicas. A modalidade de "Compra Direta" do PAA é que foi considerada. Por meio desta, o governo incentiva a compra de produtos da agricultura familiar e a distribuição em localidades próximas, "dinamizando 
a economia local e fortalecendo a geração de renda para os pequenos produtores" (PAGANINI, 2004, p. 137).

A maior contribuição da "Compra Direta" é o apoio ao "agricultor familiar no momento mais crítico da produção, que é o da venda" (PINTO, 2004, p. 143). Ao utilizar o apoio de entidades parceiras, que garantem a "retirada do produto da roça" (PINTO, 2004, p. 144), a iniciativa federal possibilitaria que o pequeno produtor fosse remunerado com o preço de mercado por sua produção, superando a defasagem imposta por intermediários e atravessadores.

$\mathrm{O}$ fato dos pequenos produtores não possuírem "meio de transporte, a não ser uma carroça ou uma charrete, que não são apropriadas para levar a produção para a feira ou mesmo para o mercado mais próximo" (PINTO, 2004, p. 145) seria um dos fatores que os diferenciam do agronegócio patronal. É importante considerar que, ao contrário de outros países, no Brasil, as políticas do setor não apresentam uma estratégia de “integrar as duas formas de produção" (GUANZIROLI, 2006, p. 31) - agricultura familiar e agronegócio patronal ${ }^{1}$. Ao contrário, as políticas são dicotômicas, situação que as permite considerar como concorrentes na escala de decisão federal.

Além disso, há ainda a disputa vista pela "ótica do novo quadro institucional e da globalização do sistema agroalimentar sob a hegemonia das transnacionais, sobretudo das de grande distribuição" (WILKINSON, 2003, p. 81). Esta visão oprime ainda mais as perspectivas de expansão da agricultura familiar num quadro espacial e político global. Apesar das dificuldades enfrentadas em diversas escalas, a participação da agricultura familiar na produção agropecuária nacional permaneceu estável na década entre 1996 e 2006 (GUANZIROLLI, 2003, p. 352).

Os conflitos entre agronegócio e agricultura familiar também marcam as ações e avanços do PNPB. Para compreender a origem desta questão é importante relacioná-los ao desenvolvimento da "crise ambiental" (BECKER, 2011, p. 294) e dos biocombustíveis.

Antes que o cenário atual dos conflitos internacionais por recursos energéticos se expandisse do interesse pelo petróleo para o desenvolvimento de combustíveis renováveis, o governo brasileiro começou a tentar reduzir a dependência ao combustível fóssil, diversificando a oferta de combustíveis com o Pró-Álcool, principalmente, a

\footnotetext{
${ }^{1}$ Este, "entendido como a soma dos setores produtivos com os de processamento do produto final e os de fabricação de insumos" (GUANZIROLI, 2006, p. 2), auto-suficiente nos processos de produção e comercialização.
} 
partir da década de 1980. Em 2003, o governo federal modifica o grupo interministerial responsável pelo Pró-Biodiesel, programa federal, e o encarrega da produção de “estudos sobre a viabilidade de utilização de óleos vegetais para fins energéticos visando definir as bases de um programa de âmbito nacional para a produção e uso de biodiesel" (FREITAS, 2011b, p. 11). O PNPB teria sido fruto da articulação de esforços do grupo interministerial que compunha o Pró-Biodiesel, instituído em 2002, e da Rede Brasileira de Tecnologia do Biodiesel (RBTB), "em prol da inclusão do biodiesel na matriz energética brasileira" (FREITAS, 2011b, p. 11), e da redução das emissões de poluentes do diesel mineral.

Em 2004, o grupo interministerial divulga recomendações para que os pilares social, econômico e ambiental sustentem o programa, considerando a competição

entre a destinação das matérias-primas empregadas (soja, mamona, dendê e outros) [e] o amplo potencial de expansão da fronteira agrícola nacional, incluindo [...] a exploração racional do semiárido e a possibilidade de se elevar a produtividade agrícola" (RODRIGUES, 2003).

O grupo mostrava preocupação com a diversificação das fontes de matéria-prima para biodiesel. No entanto,

além do consenso com relação à sojicultura, como base da inserção do biodiesel na matriz energética nacional, os estudos do GTI (grupo interministerial) não planejaram sequer uma substituição gradual dessa oleaginosa e parecem ignorar o avanço da soja tanto para o cerrado quanto para o semiárido. Infere-se, com isso, que as questões ambientais do PNPB não incorporaram preocupações com poluentes locais nem com o balanço energético da cultura (FREITAS, 2011b, p. 12).

O PNPB se apresentava como uma iniciativa "com objetivos claros de estimular os pequenos produtores e as unidades localizadas nas regiões de economias menos desenvolvidas" (NOGUEIRA, 2007. p. 52). As famílias de agricultores deveriam ser os principais beneficiados pela produção. $\mathrm{O}$ marco regulatório estabelece o biodiesel como de utilidade pública nacional. Isso significa que a produção do biocombustível estimada para os anos posteriores deveria atender ao consumo interno, devido ao aumento do índice de mistura do biocombustível ao diesel convencional, determinado pela lei federal $n^{\circ}$ 11.097/2005 (BRASIL, 2005, p. 8).

A política pública do biodiesel vem no encalço do fortalecimento dos programas voltados para a agricultura familiar durante o governo Lula. De acordo com dados divulgados pelo governo federal no final de 2005, só os recursos com o Programa 
Nacional de Fortalecimento da Agricultura Familiar (Pronaf), que até 2002 teria emprestado no máximo R\$ 2,2 bilhões, foram triplicados na safra 2004/2005 e quadruplicados na safra de 2005/2006 (ARAÚJO, 2006, p. 161). O programa do biodiesel se tornara "uma das principais apostas do governo Lula", pois promoveria "uma revolução na geração de empregos no campo, sobretudo na agricultura familiar" (ARAÚJO, 2006, p. 162).

\subsection{Valorização do espaço e do território}

Com a enunciação do contexto de ambos os programas é possível verificar a existência de contradições inerentes à existência das iniciativas. A partir daí, pretendese realizar, nessa pesquisa, um estudo multi-escalar e formular conjeturas relacionadas às metas do poder público federal para as iniciativas e os resultados apurados pela pesquisa em nível local. Para tanto, é necessário organizar alguns dos conceitos teóricos utilizados.

Com base nos estudos da Geografia Humana, é importante considerar o espaço, conforme o sentido dado ao termo pelo geógrafo Milton Santos. O baiano, nascido nas Brotas de Macaúbas, na Chapada Velha, entre as lutas dos coronéis e governadores pela disputa do poder nas Lavras Diamantinas - espaço influente do sertão nas esferas estadual e federal -, e os primeiros movimentos da Coluna Prestes na região (QUEIROZ, 1985, p. 87), propõe que o "espaço seja definido como um conjunto indissociável de sistemas de objetos e de sistemas de ação" (SANTOS, M., 2009, p. 21). Este autor afirma que a partir desta noção:

podemos reconhecer suas categorias analíticas internas. Entre elas, estão a paisagem, a configuração territorial, a divisão territorial do trabalho, o espaço produzido ou produtivo, as rugosidades e as formas-conteúdo. Da mesma maneira e com o mesmo ponto de partida, levanta-se a questão dos recortes espaciais, propondo debates de problemas como o da região e do lugar, o das redes e das escalas. [...] E do mesmo passo podemos propor a questão da racionalidade do espaço como conceito histórico atual e fruto, ao mesmo tempo, da emergência das redes e do processo de globalização (SANTOS, M., 2009, p. 22).

Diante deste exposto, é necessário considerar as dinâmicas dos programas públicos desta análise no município de Morro do Chapéu como frutos de processos que 
se dão em diversas escalas, que estão entrelaçadas e articuladas entre o local e o global. Por isso, é necessário compreender a importância das redes para a evolução do lugar e do mundo. O sociólogo espanhol Manuel Castells defende um conceito de rede semelhante ao de Milton Santos. Para ele, "a sociedade em rede", que dá nome a uma de suas obras, é:

\begin{abstract}
a sociedade em que a estrutura social é feita de redes alimentadas por informações baseadas nas microeletrônicas e nas tecnologias de comunicação. Por estrutura social, eu entendo a organização dos arranjos das relações humanas de produção, consumo, reprodução, experiência e poder expresso na comunicação significativa codificada pela cultura. A rede é um conjunto de nós interconectados. Um nó é um ponto onde a curva intercepta a si mesma. Uma rede não tem centro, só nós. Os nós podem ter relevância variada dependendo da rede. Os nós se tornam mais importantes para a rede através da absorção de informações mais relevantes e processando-as de modo mais eficiente [...] Os nós só existem e funcionam como componentes das redes. A rede é a unidade, não o nó (CASTELLS, 2004, p. 3, tradução nossa).
\end{abstract}

Em Morro do Chapéu, a existência de redes pode ser evidenciada pela organização das atividades do PNPB, por exemplo. Para isso, foi necessário o estímulo de ordem internacional à produção de fontes de energia renováveis, a articulação regional para a instalação de uma cooperativa na sede do município, que se tornou fonte irradiadora de informação, e a participação da agricultura familiar, esta interligada pelas relações sociais e cujas propriedades estão conectadas por uma série de caminhos e estradas. Da mesma forma, as funções produtivas que contribuíram para a formação territorial de Morro do Chapéu ao longo da história, como a pecuária, a própria agricultura, a mineração e, mais recentemente, a produção de energia eólica tiveram que se basear em redes para se organizarem localmente, redes cuja esfera de decisão era situada em lugares distantes, como países europeus.

Milton Santos ressalta ainda a "realidade ao mesmo tempo global e local das redes", mas descarta a oposição entre "a sociedade local a uma sociedade nacional, um território local ao território nacional” (SANTOS, M., 2009, p. 272). Como solução, define a noção de divisão do trabalho como "uma realidade e uma categoria analítica". Para o autor, o "trabalho local depende das infraestruturas localmente existentes e do processo nacional de divisão do trabalho nacional” (SANTOS, M., 2009, p. 272). Isso significa que os efeitos dos programas públicos analisados por esta pesquisa não se dão da mesma maneira em diferentes lugares, por exemplo. 
A configuração [territorial nacional] pesa diferentemente nos diversos lugares, segundo seu conteúdo material. É a sociedade nacional, através dos mecanismos de poder, que distribui, no país, os conteúdos técnicos e funcionais, deixando os lugares envelhecer ou tornando possível sua modernização. [...] As decisões nacionais interferem sobre os níveis inferiores da sociedade territorial por intermédio da configuração geográfica, vista como um conjunto. Mas somente em cada lugar ganham real significado (SANTOS, M., 2009, p. 272).

Isso ajuda a explicar como o Brasil possui regiões com níveis de condição socioeconômicas tão diferentes. O Nordeste é um exemplo disso. Apesar de ser uma das regiões do país onde a presença dos colonizadores se deu primeiro e na qual as influências econômicas externas aconteceram com intensidade para a transformação da escala local, por conta das atividades produtivas desenvolvidas, marcando permanentemente algumas áreas, o Nordeste não é tão industrializado quanto Sul e Sudeste.

Há ainda a diferenciação entre a faixa litorânea, das zonas da mata, e do interior, ou sertão nordestino, mais carente. A situação de desigualdade econômica e social, construída pela acumulação de "usos" para a diversidade local da região ao longo dos séculos, teria contribuído para que o incentivo à mamona no PNPB tivesse sido idealizado com a expectativa de "revolucionar a vida dos agricultores do semiárido nordestino" (FREITAS, 2011a, p. 41). Neste caso, ao deter a atenção sobre a esfera local torna-se possível evidenciar as relações entre as redes, a escala de influência global e o resultado no local.

De acordo com a geógrafa Iná Elias de Castro é no município que são concretizadas as políticas públicas, "é nele também que resistem e têm visibilidade os redutos da 'política clientelista', do populismo, das oligarquias etc." (CASTRO, 2005, p. 134). No caso da escala nordestina, vale a pena de antemão adotar as posições de que “a questão nordestina é uma falsa questão e deve ser deslocada da região para o espaço ocupado historicamente por suas elites" (CASTRO, 1992, p. 19) e que a permanência “das condições estruturais da Região Nordeste, apesar da modernização de alguns setores econômicos, decorre da preservação da estrutura de poder" (CASTRO, 1992, p. 20). Isso é importante, pois coloca tanto a questão política interna do Nordeste quanto a externa - a influência da política regional para a questão nacional - em evidência.

Para entender de perto como são concretizadas as políticas públicas, e tentar revelar os redutos da política clientelista, do populismo e das oligarquias, a escala municipal, no caso, de Morro do Chapéu, será utilizada. 
A escala municipal é, portanto significativa do fazer político no espaço e oferece um vasto campo para a geografia política contemporânea que vai desde a visibilidade de um espaço político de ação das organizações da sociedade civil até as decisões concretas que resultam em políticas públicas que impactam o território e a vida do cidadão. Paralelamente, este é o recorte que revela, em escala reduzida, comportamentos, valores e preferências que permitem compreender traços característicos e diferenças regionais na sociedade nacional (CASTRO, 2005, p. 134).

A valorização do espaço articula também os fatores físicos e sociais, e ainda associa à dinâmica local os estímulos exteriores, "pelo fato de que os lugares - por intermédio das pessoas - se relacionam" (MORAES, 2000, p. 16).

Desse modo, espacializar é de imediato particularizar, pois as determinações acabam dando às relações próprias de um modo de produção tonalidade locais específicas em cada lugar. Por isso que a formação econômico-social é vista, nesse sentido, sempre como uma realidade localizada temporal e espacialmente (MORAES, 2000, p. 16-17).

Para o autor, "a valorização do espaço pode ser apreendida como processo historicamente identificado de formação de um território" (MORAES, 2000, p. 17). A diferença é que este conceito "desenha-se como um objeto empírico, o ajuste de foco naquela ótica angular de se captar o movimento histórico" (MORAES, 2000, p. 17).

Do ponto de vista epistemológico, transita-se da vaguidade da categoria espaço ao preciso conceito de território. E neste, ou melhor, em sua produção, as determinações mais especificamente econômicas se associam às injunções do universo da política. Na historicidade plena dos processos singulares brota a possibilidade de indicar os agentes do processo, os sujeitos concretos da produção do espaço (MORAES, 2000, p. 17).

Assim, a tentativa de compreensão dos efeitos econômicos e políticos do PNPB e do PAA em Morro do Chapéu neste trabalho está apoiada nas considerações da influência de variados agentes ao longo da formação territorial da área na qual o município está localizado. Isso significa não apenas analisar como o espaço em questão evoluiu ao longo dos séculos, mas também refletir quais interesses eram satisfeitos enquanto isso acontecia. Isso porque, "o território é um produto socialmente produzido, um resultado histórico da relação de um grupo humano com o espaço que o abriga" (MORAES, 2000, p. 18). O geógrafo Claude Raffestin, um dos especialistas que analisaram a importância dos atores para as mudanças espaciais, afirmava que "o espaço é anterior ao território" (RAFFESTIN, 1983, p. 143). 
O território se forma a partir do espaço, é o resultado de uma ação conduzida por um ator sintagmático (ator que realiza um programa) em qualquer nível. Ao se apropriar de um espaço, concreta ou abstratamente (por exemplo, pela representação), o ator 'territorializa' o espaço (RAFFESTIN, 1983, p. 143).

Tendo em vista o objeto de estudo desta pesquisa, é importante considerar o papel do Estado como ator "sintagmático", capaz de influenciar as dinâmicas da formação territorial do local, verificadas nos efeitos apurados a partir do desenvolvimento dos programas públicos analisados. Apesar de figurar como um dos principais agentes da evolução da formação territorial do município em questão, desde antes da criação da vila de Nossa Senhora das Graças do Morro do Chapéu, em 1854, até o território atual do município, é necessário analisar também a influência de outros atores que não se limitam ao Estado-nação. Isso porque, além das disputas internas políticas pelo poder, a influência do mercado pode se mostrar decisiva para a formação territorial, especialmente, ao longo do século XX e durante o período em destaque neste estudo.

O geógrafo político inglês John Agnew pode contribuir para a compreensão deste processo quando analisa as características do sistema do mundo moderno e afirma que este é caracterizado pela economia política global. Para ele nenhuma economia nacional possui um papel dominante e muitos atores, incluindo corporações multinacionais e bancos transnacionais, são globais em perspectiva e organização.

Os estados precisam operar agora em um contexto global no qual eles são efetivamente, mas desigualmente, internacionalizados. Neste contexto, regiões e localidades dentro de estados se tornaram cada vez mais vulneráveis para pressões emanadas de fora para o 'estado nacional' (AGNEW, 2003, p. 9, tradução nossa).

Em outras palavras, "as novas tendências de globalização econômica e dos movimentos sociais rompem as fronteiras dos Estados [e] novas territorialidades [...] surgem acima e abaixo da escala do Estado" (BECKER, 2011, p. 272). O mesmo vale para o movimento ambientalista, que contribuiu de maneira importante para o avanço do "desenvolvimento sustentável”, "uma feição específica da Geopolítica contemporânea" (BECKER, 2011, p. 292) como expressão de uma nova "racionalidade" (BECKER, 2011, p. 296) em escala global. 
De acordo com a geógrafa, “o Estado não é mais a única representação do político nem a única escala de poder, mas certamente é uma delas, mantendo-se ainda, embora com novas formas e funções" (BECKER, 2011, p. 299).

O Estado certamente não é a unidade única representativa do político nem o território nacional a única escala de poder. $\mathrm{O}$ poder tecnoeconômico é efetivo. [...] Atribuindo valor estratégico aos territórios, em qualquer escala geográfica, segundo o seu conteúdo científico-tecnológico e informacional (BECKER, 2011, p. 303).

A participação dos movimentos ambientalistas na definição de acordos internacionais, o desenvolvimento de uma série de organismos políticos internacionais ao longo do século XX e a influência destes atores para a adoção de medidas por parte de governos, como no caso do PNPB, são exemplos. Estas medidas, por sua vez, rebatem de diferentes maneiras nos territórios, promovendo, a expansão das áreas plantadas com mamona e com outras culturas destinadas ao biodiesel, por exemplo.

Ao recuperar as fases da relação histórica entre o Estado e o espaço há de se ressaltar o período em que o capitalismo "passa a se reproduzir não mais apenas nas relações econômicas, mas, sim, também nas relações sociais de produção", "na sociedade inteira e no espaço inteiro" (BECKER, 2011, p. 285). A partir daí, o "valor estratégico do espaço [...] se torna condição de reprodução generalizada e, como tal, o espaço de poder" (BECKER, 2011, p. 285).

\footnotetext{
A inovação tecnológica representada pelas redes transnacionais de circulação e comunicação permite a um só tempo a globalização como a diferenciação espacial [...] resultando na valorização seletiva de territórios. [...] criam-se condições para a internacionalização da economia num mercado unificado, e um espaço de fluxos financeiros, mercantis e informacionais tende a superar os Estados e as fronteiras, delineando uma nova divisão territorial de trabalho e uma nova geopolítica. [...] O valor econômico e estratégico de um território decorre da velocidade em passar à nova forma de produção, para o que o acesso às redes de informação é condição essencial, permitindo ao local se relacionar diretamente ao espaço transnacional, 'by passando' o Estado (BECKER, 2011, p. 287-288).
}

A indústria de energia eólica, cuja atuação não será aprofundada nesta pesquisa, por exemplo, pautada na evolução da tecnologia de produção e na disseminação do discurso da importância das fontes energéticas renováveis de energia, recentemente, qualificou uma série de áreas de Morro do Chapéu como potenciais para a implantação de parques eólicos. A medida provocou novas dinâmicas territoriais na área. É possível que a ação das empresas do setor tenham inclusive influenciado a tentativa de 
revogação do decreto de criação do Parque Estadual de Morro do Chapéu (PEMC), a maior área de conservação do município (BAHIA, 2011), estratégica do ponto de vista ambiental.

Num curto período de tempo, as localidades com potencial de geração de energia eólica do município ganharam o interesse das empresas estrangeiras que possuíam a tecnologia de produção. Rapidamente estas áreas foram inseridas na lógica da globalização e a participação do poder público local e estadual pode ter favorecido a evolução de novas dinâmicas para o território de Morro do Chapéu. No entanto, nesta hipótese, a figura do Estado teve uma ação passiva, apenas facilitando a inserção física e espacial das empresas no território do município.

A tarefa de analisar a influência de distintos atores para a formação territorial de um dado lugar, inclusive aqueles cujos "nós" se concentram além das fronteiras brasileiras tem como meta:

incorporar uma antiga lição da geografia política, que nos recomenda procurar desvendar o sentido geral e as expressões concretas das relações internacionais a partir da identificação das suas particularidades e singularidades ou, em outros termos, mediante um esforço de territorialização ou de regionalização dos eventos políticos e político-estratégicos (COSTA, 2009, p. 3).

O geógrafo Rogério Haesbaert da Costa compara a diferenciação utilizada por Milton Santos entre espaço e território à de Raffestin e revela que a definição de "espaço geográfico" como interação "entre um sistema de objetos e um sistema de ações" (HAESBAERT, 2007, p. 61) explicitaria "a base materialista de fundamentação econômica" no trabalho do brasileiro. Isso inseriria o conceito de território utilizado por Milton Santos dentro de uma concepção de base econômica.

\footnotetext{
O território reúne informações local e externamente definidas, vinculadas a um conteúdo técnico e a um conteúdo político, uma dialética que 'se afirma mediante um controle 'local' da técnica de produção'. O comando 'local' do território depende de sua densidade técnica e/ou funcional-informacional, enquanto o 'controle distante', global, a 'escala da política', ao contrário do que acontecia 'antes do enfraquecimento do Estado territorial', é completamente dissociado, o que acirra os conflitos entre 'um espaço local, espaço vivido por todos os vizinhos e um espaço global' racionalizador e em rede (HAESBAERT, 2007, p. 60).
}

Apesar do destaque dado às influências dos aspectos econômicos e políticos para a compreensão da formação territorial em Morro do Chapéu, é importante ressaltar que ainda outra série de fatores que contribuíram para a análise, mas que se manterão como 
pano de fundo da pesquisa. Estes fatores fazem parte das perspectivas idealistas, que integram aspectos simbólicos como formadores do território, como a noção de identidade cultural. "Isto significa que o território carregaria sempre, de forma indissociável, uma dimensão simbólica, ou cultural em sentido estrito, e uma dimensão material, de natureza predominantemente econômico-política", o que possibilitaria uma “abordagem 'integradora' de território” (HAESBAERT, 2007, p. 74).

Nesta abordagem o geógrafo defende que a implementação das "políticas de ordenamento territorial” torna necessária a consideração de duas características básicas do território: o caráter político, "no jogo dos 'macropoderes', muitas vezes mais simbólicos, produzidos e vividos no cotidiano das populações"; e o caráter integrador, “o Estado em seu papel gestor-redistributivo e os indivíduos e grupos sociais em sua vivência concreta" (HAESBAERT, 2007, p. 76).

Uma das perspectivas que se abrem a partir daí é a de promover "uma leitura com base no território como rede" (HAESBAERT, 2007, p. 77). Nesta perspectiva o geógrafo se apóia nas considerações da parceira de trabalho, a britânica Doreen Massey. Para ela, "os lugares não têm de ter fronteiras no sentido de divisões demarcatórias" (MASSEY, 2000, p. 184).

\footnotetext{
o que dá a um lugar sua especificidade não é uma história longa e internalizada, mas o fato de que ele se constrói a partir de uma constelação particular de relações sociais, que se encontram e se entrelaçam num locus particular. O lugar é um 'ponto particular' único desta intersecção (MASSEY, 2000, p. 184).
}

Deixar de ampliar as considerações sobre a grande diversidade de conceitos e se ater aos limites impostos pela administração pública para o território de Morro do Chapéu, mesmo que não os adotando, representaria desconsiderar uma série de relações que se dão além dos limites do município. Isso imporia sérios limites à pesquisa. É necessário dar destaque para o local, para os acontecimentos que estão em curso no lugar, pois este "sempre dinâmico e em aberto, conectado ao mundo" também está “mergulhado na densa espaço-temporalidade da própria natureza, nunca estática, que se reconstrói permanentemente em sua indissociável vinculação ao igualmente complexo mundo dos homens" (MASSEY, 2009, p. 12).

De acordo com Haesbaert, territorializar-se significa: 
criar mediações espaciais que nos proporcionem efetivo 'poder' sobre nossa reprodução enquanto grupos sociais (para alguns também enquanto indivíduos), poder este que é sempre multiescalar e multidimensional, material e imaterial, de 'dominação' e 'apropriação' ao mesmo tempo (HAESBAERT, 2007, p. 97).

Por isso, o conceito de território adotado por este estudo está mais caracterizado por um híbrido do que fechado numa das denominações já consagradas. Para facilitar a aproximação entre o exercício conceitual e a prática da análise é que algumas categorias analíticas a respeito do espaço foram consideradas. Para Milton Santos, há quatro categorias distintas que podem contribuir para o estudo: formas, funções, estrutura e processos.

\footnotetext{
O espaço deve ser considerado como um conjunto de relações realizadas através de funções e formas que se apresentam como testemunho de uma história escrita por processos do passado e do presente. Isto é, o espaço se define como um conjunto de formas representativas de relações sociais do passado e do presente e por uma estrutura representada por relações sociais que estão acontecendo diante de nossos olhos e que se manifestam através de processos e funções. O espaço é, então, um verdadeiro campo de forças cuja aceleração é desigual. Daí porque a evolução espacial não se faz de forma idêntica em todos os lugares (SANTOS, 2008, p. 153).
}

Considera-se a forma, a função, a estrutura e o processo, tomados em conjunto e relacionados entre si, para discutir os fenômenos espaciais em totalidade. "O fator primário de qualquer situação só pode ser revelado após um exame cuidadoso da totalidade" (SANTOS, 1985, p. 52). A recuperação de aspectos das formas, funções e da estrutura da área compreendida hoje como Morro do Chapéu durante processos históricos representativos ocorridos ao longo dos séculos de ocupação é que deverá contribuir com o desvendamento da totalidade espacial do município. Essa totalidade, por sua vez, embasará as dinâmicas verificadas e ocorridas a partir do PNPB e do PAA.

O geógrafo defende que é possível reduzir cada um daqueles conceitos citados até designar:

uma forma significante, uma estrutura dominante ou uma função prevalecente. [...] Finalmente, transformações históricas e variações locais demandam uma contínua rotação dos temas dominantes [...] forma, função, processo e estrutura devem ser estudados concomitantemente e vistos na maneira como interagem para criar e moldar o espaço através do tempo (SANTOS, 1985, p. 52).

Tentando estabelecer relações entre as categorias analíticas propostas pelo geógrafo e o objetivo deste trabalho, é possível partir da análise das formas - “o aspecto 
visível de uma coisa", o "arranjo ordenado de objetos", "um padrão" (SANTOS, 1985, p. 50) - da área de estudo. Estas formas são compreendidas como "produtos sociais e históricos", "produtos de nossa percepção histórica e social” (GOMES, 1997, 23), “o objeto possível de investigação", não um dado "e sim uma construção" (GOMES, 1997, 26).

As propriedades rurais dos cooperados de uma organização entre as que trabalham para o PNPB e o PAA foram analisadas sobre a perspectiva da forma, ou tendo a forma, como ponto de partida da análise. Para isso, é importante considerar o arranjo no qual estão inseridas estas propriedades. Em Morro do Chapéu, estas áreas estão distribuídas pelo território do município, geralmente, em aglomerados que rodeiam povoados. São propriedades, geralmente, entre cinco e 50 hectares que não são diretamente abastecidas por fluxos de água corrente. Geralmente, fazem limites com propriedades maiores.

A sede do município e os diversos povoados localizados nos diferentes distritos da zona rural também são considerados entre as formas do espaço. Em muitos casos os agricultores familiares residem nos povoados mais próximos das propriedades, onde se dão as principais relações comerciais e sociais. Por vezes estas e outras relações, entre elas as burocráticas e financeiras, também ocorrem na sede de Morro do Chapéu ou das cidades vizinhas.

$\mathrm{O}$ estímulo do poder público em fazer a agricultura familiar atender às necessidades dos programas públicos também produziu mudanças nas formas espaciais no município. Ao mesmo tempo, este estímulo pode representar uma nova função determinada pelo poder público federal para a agricultura familiar e as áreas em propriedade destas famílias. A função aqui é entendida como "tarefa ou atividade esperada de uma forma, pessoa, instituição ou coisa" (SANTOS, 1985, p. 50). Conforme fora visto, ao longo dos séculos a área de Morro do Chapéu foi influenciada por uma série de outras funções que também foram consideradas, entre elas a pecuária e a mineração.

Do mesmo modo foi analisada a função da principal cooperativa de agricultores familiares do município em atender as demandas do PNPB e o PAA, assim como a função do poder público e dos demais atores hegemônicos para o processo de formação territorial de Morro do Chapéu. A função dos programas públicos em promover a emergência política de grupos na escala local também foi analisada. 
O território é a estrutura da análise, "inter-relação de todas as partes de um todo; o modo de organização ou construção" (SANTOS, 1985, p. 50), e está apenas esboçado nos limites da divisão político-administrativa do município. Esta delimitação deve ser flexibilizada dependendo das relações estabelecidas entre os atores, povoados e demais elementos analisados. Isso porque, mesmo as relações comerciais de muitos povoados distantes da sede, por exemplo, se dão além do território do município. As distâncias entre os povoados e os centros administrativos da região são determinantes para a influência econômica, ao contrário das atividades burocráticas que se concentram na sede de Morro do Chapéu.

Cada processo que contribuiu para a formação territorial de Morro do Chapéu foi considerado "uma ação contínua, desenvolvendo-se em direção a um resultado qualquer, implicando conceitos de tempo (continuidade) e mudança" (SANTOS, 2008, p. 69). No entanto, o processo que se deu a partir de 2007, quando os programas públicos passam a exercer influência sobre o município, é que receberá maior destaque.

De antemão vale revelar alguns daqueles processos. Espera-se, com isso, contribuir para a compreensão de como estão refletidos no território e nos setores da produção de alimentos e da produção de biocombustíveis na escala local. A expectativa é que esta pesquisa também contribua para a formulação de conjeturas sobre como funções, formas e estruturas evoluíram ao longo dos séculos até chegarem à realidade local atual.

A proposta aqui é resgatar o passado não para discutir "propriamente a objetividade do fato histórico, mas sim a relação entre esta intenção e o relato que dela resulta" (GOMES, 1997, 31). Espera-se que a revelação de aspectos de formação do arranjo espacial contribua para uma melhor compreensão do processo mais recente da história de Morro do Chapéu. A busca é por esta "ordem espacial das coisas", da "lógica da sua distribuição", da "coerência" (GOMES, 1997, 35) do espaço analisado.

\subsection{Ocupação sertaneja e geografia política}

Obviamente, alguns processos ocorridos em Morro do Chapéu ganharão maior atenção neste trabalho em detrimento de outros, que serão apenas brevemente considerados. A dificuldade de deter-se em todos os processos ocorridos na área é 
evidenciada pelo histórico da ocupação humana na região. Além das pinturas rupestres, a presença de comunidades primitivas e tribos indígenas no Morro do Chapéu pode ser comprovada pelos "indícios permanentes de malocas" nas "serras do Tareco e na Baixa do Baeta" estabelecidas "em épocas muito distantes" (CUNEGUNDES, 1981, p. 13).

A chegada dos colonizadores coincidiu com o período no qual os índios que habitavam a região passaram a ser dizimados. O processo se deu a partir das doações de terras e sesmarias "que penetravam cada vez mais o sertão" (ANDRADE, 1998, p. 167) para senhores que possuíam influência junto à coroa portuguesa. De acordo com o autor, as terras de Morro do Chapéu no início do século XVIII haviam se tornado divisoras de dois dos maiores latifúndios do país (ANDRADE, 1998, p. 167).

Os posseiros trabalhavam para os senhores que tinham influência junto aos Governadores Gerais, no caso de Morro do Chapéu, os latifundiários da "Casa da Ponte" e da "Casa da Torre" (CUNEGUNDES, 1981, p. 105). Ambas as "casas" são destaque na análise da mobilidade "das instalações" e a "perenização de certos fluxos e das relações entre diferentes lugares da colonização", já visível em fins do século XVI na Bahia (MORAES, 2000, p. 402). Para o autor, neste período, a Bahia já poderia ser considerada na escala de região, visto agrupar "uma rede de povoações interrelacionadas, objetivando um espaço de povoamento contínuo" (MORAES, 2000, p. 402).

A pecuária passa a caracterizar a região de Morro do Chapéu seja por conta da criação no local ou da manutenção de pastos para alimentação das boiadas que vinham de outros lugares com destino a Salvador (QUEIROZ, 1985, p. 17). Nesta lógica, a agricultura pode ser considerada posterior ao "desbravamento do interior e da criação de gado" (ANDRADE, 1998, p. 174)

\footnotetext{
Apenas a agricultura não foi a atividade principal; desenvolveu-se à sombra dos 'currais', devido à grande distância que separava aquela zona do litoral e ao elevado preços que os gêneros atingiam após o transporte por dezenas de léguas. Era feita, porém de forma penosa, sendo os pequenos campos cultivados limitados por cercas ou valados que vedavam não só a passagem de bovinos e eqüinos, como também das 'miunças' - bodes e carneiros [...] Essa agricultura restringia-se apenas à mandioca, ao milho, feijão, algodão e, às vezes, à melancia e ao melão (ANDRADE, 1998, p. 174).
}

Ainda de acordo com o autor:

esses pequenos roçados eram feitos, a princípio, pelos próprios vaqueiros com a sua família ou agregados, de vez que os proprietário não tinham preocupação 
direta com o abastecimento de seus pressupostos. Estes é que deviam prover a sua alimentação, dentro das condições que o meio natural lhes oferecia (ANDRADE, 1998, p. 174).

No caso de Morro do Chapéu, a própria proximidade com o rio Salitre devia prover até o sal consumido. Lembre-se a distância e as dificuldades de acesso entre os povoados e a sede e desta em relação à capital Salvador - distante cerca de 400 quilômetros. Estas são algumas das características do início da produção de gêneros alimentícios em Morro do Chapéu após a colonização, fundamentais para compreender em quais condições acontece a produção de alimentos no local e como evolui o arranjo fundiário do município.

Este arranjo tem origem na alta concentração de terra do sertão, ilustrada pela obra do jesuíta André João Antonil:

\footnotetext{
Sendo o sertão da Bahia tão dilatado, como temos referido, quase todo pertence a duas das principais famílias da mesma cidade, que são a da Torre, e a do defunto mestre de campo Antônio Guedes de Brito. Porque a casa da Torres tem duzentas e sessenta léguas pelo rio de São Francisco, acima à mão direita, indo para o sul, e indo do dito rio para o norte chega a oitenta léguas. E os herdeiros do mestre de campo Antônio Guedes possuem desde o morro dos Chapéus até a nascença do rio das Velhas, cento e sessenta léguas. E nestas terras, parte os donos delas têm currais próprios, e parte são dos que arrendam sítios delas, pagando por cada sítio, que ordinariamente é de uma légua, cada ano, dez mil réis de foro (ANTONIL, 1982, p. 96).
}

Em outra obra, há o registro de que foram o próprio $6^{\circ}$ Conde da Ponte e a esposa, Joana Castelo Branco, da "Casa da Torre", donos da sesmaria de "170 léguas" que se estendia até o rio São Francisco, que "iniciaram a venda de grandes áreas" em Morro do Chapéu (CUNEGUNDES, 1981, p. 105). Aproximadamente 25 áreas são vendidas a proprietários que, “em obediência à Lei de 1854, foram obrigados a levá-las a registro, ato a cargo do vigário da Freguesia da situação do imóvel" (CUNEGUNDES, 1981, p. 105).

Em meados do século XIX as formas da área de Morro do Chapéu já haviam sofrido muitas mudanças em relação ao território encontrado antes da colonização. Caminhos utilizados para a circulação e comunicação de indígenas haviam sido ampliados, novas rotas para o transporte de mercadorias, circulação de pessoas e animais haviam sido criadas e núcleos habitacionais se desenvolviam interligados àqueles caminhos. 
A pecuária era a principal função da área. A atividade era incentivada pela colônia e coordenada pelos sesmeiros a fim de apoiar a produção de açúcar do Recôncavo baiano. Conforme fora visto, além do ator colonial, externo, definidor de quem seria a responsabilidade de administrar a sesmaria e com qual finalidade, a Igreja, um ator de atuação transacional, tinha status de autoridade na esfera local, agenciando a evolução fundiária.

Os antigos caminhos que passavam por Morro do Chapéu, nos quais as boiadas eram tangidas, passaram a ganhar novas ramificações com a abertura de estradas que ligavam Jacobina (BA), o rio São Francisco e Minas Gerais, passando pela fazenda Gameleira, onde depois se consolidaria a sede de Morro do Chapéu. A esta época, as terras da propriedade já haviam sido adquiridas do $6^{\circ}$ Conde da Ponte.

A lavra diamantina havia se iniciado no Tijuco, onde hoje fica a cidade de Diamantina (MG), ao redor de 1728. “Com a descoberta das minas, a zona pastoril do Nordeste tornou-se também subsidiária da região mineradora que lhe ficava imediatamente ao sul" (AB'SABER et al., 2011, p. 245). No lado baiano, a exploração de diamantes foi se desenvolver "somente depois de decretada a liberdade de exploração de diamantes em 1832, com a revogação do monopólio" real (MORAES, 1963, p. 8). No Morro do Chapéu o garimpo de diamantes também tem sucesso em diversas localidades entre o final do século XIX e o início do século XX.

O território do município começa a ganhar contornos a partir da lei provincial que criou o distrito de Morro do Chapéu, pertencente ao município de Jacobina, em 1838. Vinte e seis anos depois o distrito foi desmembrado e elevado à condição de vila. Em 1911, o município era constituído pelos distritos de Morro do Chapéu, Canabrava do Miranda, Caraíba, Riachão do Utinga e Ventura. O distrito que dá nome ao município e o do Ventura são os únicos que ainda fazem parte do território de Morro do Chapéu. Canabrava do Miranda se tornou Canarana, Caraíba deu origem às cidades de Irecê e América Dourada e o Riachão do Utinga foi desmembrado entre os municípios de Utinga e Bonito.

É no período do auge do garimpo de diamantes que os coronéis Dias Coelho e Souza Benta ganham notoriedade na sede, em todo o município e na região. Para Cunegundes (1981, p. 39), o coronel Souza Benta, que assumiu a direção e a "chefia" política do município após a morte de Dias Coelho, em 1919, e faleceu em 1946, foi o responsável por abrir as primeiras estradas carroçáveis que ligavam Morro do Chapéu 
aos municípios vizinhos, especialmente a partir de 1928. Com a abertura da BR-52, o parque rodoviário é construído em 1959.

O fim do coronelismo pode ser considerado também o início da história recente de Morro do Chapéu, período que se estende até os dias atuais. É a época na qual as propriedades rurais, as formas mais evidentes na zona rural, começam a ser sucessivamente subdivididas. O município passa por um processo de adensamento demográfico e de intensificação da rede de infra-estrutura, representada pelas estradas, pela distribuição de energia elétrica e, posteriormente, o saneamento básico.

Para Cunegundes, a chegada do progresso em Morro do Chapéu se deu em meados do século XX quando:

\footnotetext{
outros meios para distrair foram surgindo, modificando quase tudo. $\mathrm{O}$ caminhão substituiu o carro de boi lento e chiador. O automóvel substituiu o cavalo passeiro, bem ajaesado, para orgulho do cavaleiro, portando chibata cabo de prata, esporas brilhantes no calcanhar de russianas de cano alto. Os aviões começaram a cruzar nossos céus (CUNEGUNDES, 1961, p. 58).
}

Já Manuel Correia de Andrade afirma que "tem sido o caminhão, nessas duas últimas décadas, o grande conquistador do Sertão, o veículo que vem quebrando estruturas seculares e transformando os gêneros de vida delas decorrentes" (ANDRADE, 1998, p. 186). Antes, uma viagem tangendo entre 100 e 300 cabeças de gado desde Morro do Chapéu até o mercado consumidor no Recôncavo deveria durar uma média de 10 dias, com água disponível durante todo o caminho (ANDRADE, 1998, p. 187).

Este passado ainda se faz presente ora mais, ora menos intensamente em alguns setores do município. Deter-se em alguns dos fatores do acúmulo de acontecimentos históricos pode ajudar a compreender um processo recente da formação territorial do município, considerado desde o ano de 2007 até 2012. Esta fase coincide com a chegada dos dois programas públicos analisados pelo estudo, o PAA e o PNPB, em Morro do Chapéu, executados pela Coopaf.

Dentro das dinâmicas das redes que as envolvem, as atividades destes programas públicos reconfiguraram as estruturas agrária e, consequentemente, social, econômica e política, remanescentes de processos históricos. Sem eliminá-las, mas coexistindo com elas, formas e funções espaciais que remetem aos períodos anteriores passam por novas dinâmicas na esfera local a partir das normas elaboradas pelo governo federal para os programas públicos. 
A influência do Estado passou a ser marcante em Morro do Chapéu desde o período colonial, quando Gabriel Soares, em posse do roteiro traçado por seu irmão, João Coelho de Souza, vai à Europa e obtém de Felipe II o título de capitão-mor e governador da Conquista e descobrimento do São Francisco. É com a autorização da coroa portuguesa que Gabriel Soares chega à Bahia e organiza uma bandeira com 360 homens e parte pelo rio Paraguaçu, atravessa as matas do Orobó, o Jacuípe, o Itapicuru; alcança as terras onde depois se ergueu Jacobina, encontrando ouro; e se dirige ao vale do rio Salitre, "procurando as nascentes do São Francisco" (CUNEGUNDES, 1981. p. 13). Em 1622, com a descoberta do ouro, Jacobina já era habitada e explorada por Belchior Dias, "que faleceu naquele ano" (CUNEGUNDES, 1981. p. 15).

De acordo com documento transcrito na obra de Jubilino Cunegundes, em 1841 o terreno dos arredores do arraial e Freguesia de Nossa Senhora da Graça com a Fazenda do Morro é doado a "Nossa Senhora da Graça", para regalia de:

todos os moradores e às pessoas que aqui quiserem formar moradas com permissão do Administrador da Igreja que estiver servindo o qual juntamente com o Sr. Juiz de Paz que então for concederão as licenças necessárias para o alevantamento de qualquer casa (Figura 1.2.1) que porventura conseguirem edificar, assim como dos terrenos para quintaes (CUNEGUNDES, 1981, p. 19).

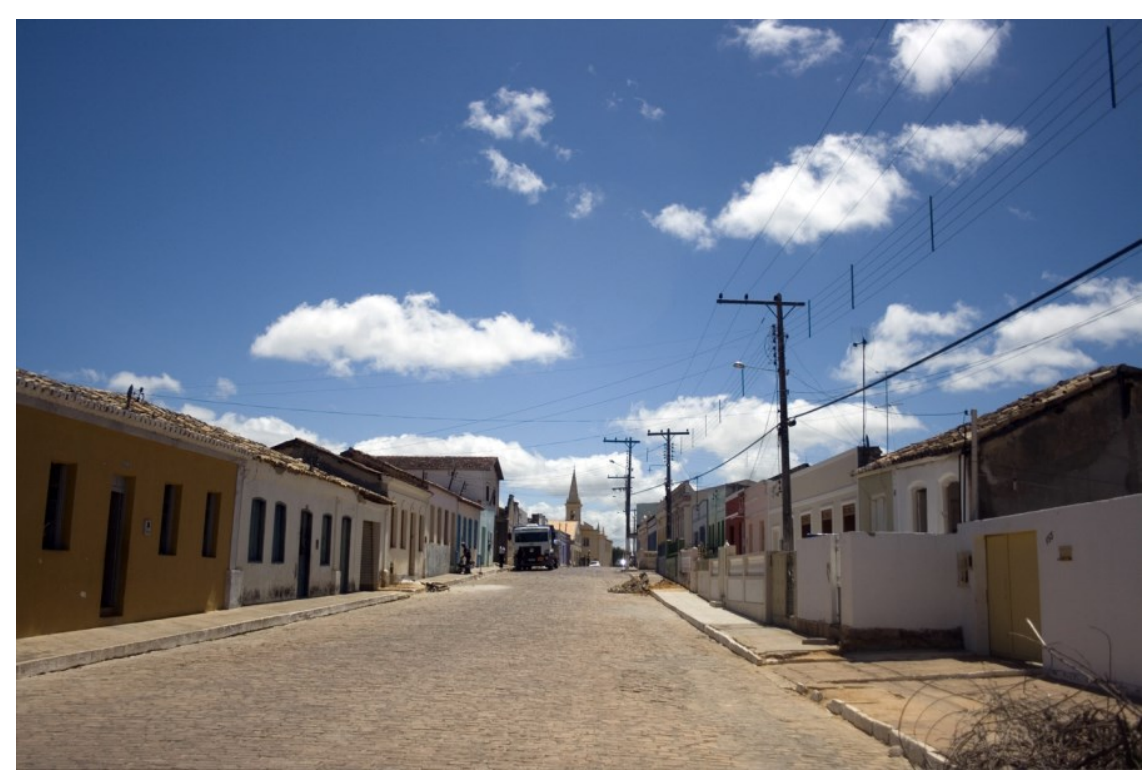

Figura 1.2.1 - Rua Coronel Souza Benta, ou rua do Fogo, via onde residiram alguns dos principais chefes políticos de Morro do Chapéu. Foi a partir da igreja Matriz, ao fundo da fotografia, que as principais ruas se formaram e a cidade se expandiu. Foto: Vinicius Morende, em 03/09/2009. 
O Estado nacional passa a modificar o espaço do município especialmente a partir de 1909, com a elevação de Morro do Chapéu à condição de cidade. A partir de então, uma série de obras de infra-estrutura começa a ser realizada na sede e na zona rural por força de recursos públicos, especialmente, federais. A partir de então, parece ficar ainda mais evidente a importância do poder público e dos subsídios de recursos financeiros públicos para a evolução técnico-produtiva do território do município.

Para entender como está constituído o poder público local é necessário analisar as famílias tradicionais do município, que, na maioria, até hoje ocupam os principais quadros políticos do lugar. Em alguns casos, estes representantes ascenderam politicamente e passaram a atuar no governo estadual e federal por meio de mecanismos políticos conservadores ainda em voga, especialmente, no sertão.

Quando as terras de Morro do Chapéu passam a ser repartidas, o número de integrantes de algumas famílias de proprietários começa a aumentar. Jubilino Cunegundes refere-se a elas como "famílias numerosas" (CUNEGUNDES, 1981, p. 106). Este autor cita 31 famílias "descendentes dos primeiros habitantes", e "tantas outras, também importantes na vida de Município". A partir das experiências obtidas por outra série de atores é que uma economia de força local passa a se desenvolver e promover financeiramente e politicamente alguns grupos familiares seja por meio do comércio, ou de um bom cargo no funcionalismo, nos serviços públicos, financeiros, seja trabalhando nas cadeias produtivas relacionadas às culturas agrícolas.

As disputas internas entre as famílias tradicionais ou entre famílias rivais é que geraram os conflitos políticos históricos que resultaram em mortes e na emancipação de distritos que faziam parte do território "original" de Morro do Chapéu. Obviamente, a influência do mercado e o próprio desenvolvimento alcançado por alguns lugares podem ter se mostrado decisivos na maior parte destes casos que se desenvolveram ao longo do século XX.

Apesar de possuir parte do território em terras semi-áridas, há diversas localidades nas quais vivem milhares de pessoas espalhadas por todo o município. Isso seria fruto de um processo de migração oriundo da falta de perspectivas de trabalho e de influência social durante o Brasil ainda colônia. O fato teria promovido fluxos de pessoas da capital do país, na época, Salvador, e do Recôncavo para as áreas do sertão em busca de trabalho na pecuária e de áreas em que estivessem autorizados a plantar e sobreviver. 
"Apesar das condições pouco favoráveis para a pecuária, o homem foi impelido para a zona das caatingas” (AB'SABER et al., 2011, p. 247). Esta ocupação pastoril começou pela Bahia e depois se desenvolveu pelos demais estados do Nordeste até quase chegar ao litoral do Maranhão. “A região das caatingas era o hinterland da zona mais densamente povoada, mais rica e mais antiga da colônia. A criação de gado no sertão do Nordeste abastecia a zona da cana e dava vazão aos excedentes demográficos da mesma" (AB'SABER et al., 2011, p. 246).

Os escravos parecem ter sido trazidos para Morro do Chapéu a partir da exploração do gado e, possivelmente, para a produção de gêneros agrícolas. É visível a presença dos remanescentes quilombolas em diversas localidades do município, entre eles os do Velame. A agricultura de subsistência e, posteriormente, a comercial de baixa, média e alta intensidade se desenvolveram tanto nas partes mais baixas e mais secas do município, quanto nas veredas e vales que acompanham o curso dos rios. A evolução da atividade foi baseada nas propriedades rurais pelas mãos dos escravos, depois pelos meeiros e finalmente pelos diaristas, ou assalariados.

A fragmentação das propriedades rurais também consolidou um grupo representativo de agricultores familiares que cuidam da própria propriedade e complementam a renda servindo a outros produtores ou executando outras atividades, como o comércio, aposentadorias etc. Historicamente, as principais culturas agrícolas cultivadas em esquema de sequeiro ${ }^{2}$ nas caatingas e no sertão de Morro do Chapéu foram o feijão, o milho, a mandioca, a cana-de-açúcar e a mamona.

Teria sido a fertilidade do solo da região do rio Utinga que favoreceu a fixação de exploradores e o desenvolvimento das primeiras plantações e a edificação de moradias na região. Em relação às produções extensivas agrícolas, de acordo com Jubilino Cunegundes, foi a cultura do café que possibilitou ao distrito sede nas últimas décadas "ficar em pé de igualdade com os distritos de Duas Barras do Morro, Ventura e Dias Coelho, detentores de maior número de propriedades valorizadas. Essas terras, em parte, muitos descendentes dos primeiros donos ainda as possuem" (CUNEGUNDES, 1981, p. 106).

O destino da produção excedente dos pequenos produtores e agricultores familiares de Morro do Chapéu produtores de gêneros alimentícios costuma ser as feiras e os comércios locais. Poucos são os gêneros produzidos em propriedades administradas

\footnotetext{
${ }^{2}$ Termo utilizado para designar o modo de cultivo agrícola camponês dependente da pluviosidade no semi-árido.
} 
por famílias que têm capacidade de serem comercializados em outras regiões. No comércio local, estes produtos enfrentam a concorrência dos alimentos distribuídos por empresas regionais, nacionais e transnacionais. Com a criação do PAA, uma nova lógica passa a influenciar a produção de gêneros alimentícios no município.

O significado do cultivo de oleaginosas no sertão para a produção de biocombustíveis, e a influência de diversos atores neste esquema, exige uma análise ainda mais criteriosa. Para tanto, é necessário fazer uma breve contextualização da situação da matriz energética mundial, diretamente ligada ao avanço da temática ambiental.

\subsection{Matriz energética global e formação territorial}

Até a década de 1970 o mundo ainda estava sobre intensa influência do paradigma do industrialismo, que associado com a revolução industrial é:

\footnotetext{
caracterizado pela organização sistêmica das tecnologias baseadas na capacidade de gerar e distribuir energia por máquinas produzidas por humanos sem depender do meio ambiente natural - embora eles utilizem a contribuição de recursos naturais para a geração de energia (CASTELLS, 2004, p. 8, tradução nossa).
}

A partir do último quarto do século passado, o "informacionalismo" passa a ser o "paradigma que constitui a base material do início do século XXI" (CASTELLS, 2004, p. 9, tradução nossa). Mesmo assim, o industrialismo não desaparece. "O informacionalismo pressupõe o industrialismo, como energia, e suas tecnologias associadas continuam como um componente fundamental de todos os processos" (CASTELLS, 2004, p. 9, tradução nossa).

Mais do que nunca, os países precisam de energia para se inserirem competitivamente dentro da "sociedade em rede" e do fluxo de evolução das tecnologias. As relações internacionais que se desenvolvem a partir desta necessidade podem tanto se dar por meio da cooperação - como no caso sul-americano da integração energética, o que ainda permite disputas pacíficas entre os países -, quanto do conflito como no caso da presença agressiva dos Estados Unidos e Organização do Tratado do Atlântico Norte (Otan) no Oriente Médio. 
Tomando como exemplo o caso do petróleo, os governos não são os únicos atores reguladores da produção, distribuição e uso. As empresas transnacionais do setor também exercem poder político relevante dentro da estrutura de organização mundial do setor. "Mais importante que o número de Estados é o aumento de atores não-estatais. Grandes empresas multinacionais, por exemplo, atravessam fronteiras internacionais e por vezes controlam mais recursos econômicos do que muitos estados-nação", alertou Joseph Nye citando a Shell como exemplo (NYE, 2002, p. 9).

Milton Santos considera que "a existência de redes é inseparável da questão do poder" e ressalta a posição dos geógrafos Michael Haddrick Taylor e Nigel Thrift, para quem os sistemas de poder inerentes à ação das grandes organizações têm um papel importante na construção das estruturas organizacionais. No entanto, Santos pondera que "faltava acrescentar que a própria estrutura do espaço constitui uma condição fundamental ao exercício de poder e à natureza local ou regional desse poder”, tomando o poder como a capacidade de uma organização para controlar os recursos necessários ao funcionamento de uma outra organização (SANTOS, M., 2009, p. 271).

A ordem global leva a interpretações do que é possível esperar para o futuro das relações envolvendo o petróleo e do modelo de desenvolvimento vigente. Para isso, é importante analisar uma das macro-tendências desta ordem, a da globalização econômica, caracterizada pelo "capital flexível", ou o que autores como Castells e Milton Santos convencionaram chamar de capital informacional, cujo pano de fundo do processo de formação é a desmaterialização do capital produtivo; o capital financeiro, ou produtivo, volátil; e o comércio internacional, o livre comércio e a competição.

Com a descentralização produtiva, o fortalecimento do sistema financeiro e a intensificação da globalização, o capital produtivo, cada vez mais volátil, se autonomiza e torna-se global, assim como as empresas. As disputas em torno do acesso ao petróleo se intensificam junto com a variação de preços da matéria-prima. Os constantes colapsos das balanças comerciais por conta da dependência da importação dos combustíveis fazem os governos adotarem medidas alternativas.

No caso brasileiro, o Programa Nacional do Álcool (Pró-Álcool) é criado e responde, em parte, à valorização do capital informacional, uma mistura de informação, ciência e tecnologia, que passa a ganhar cada vez mais importância. Mesmo com o sucesso do programa, até hoje se questiona o fato de que o governo não aumentou sua capacidade de controlar os preços internos do petróleo e do etanol no país. 
É difícil tratar da política por trás do uso do petróleo sem considerar a influência do governo dos Estados Unidos no setor. Durante a Conferência Nacional de Bioenergia (Bioconfe), realizada em 2007, um representante do governo brasileiro informou que as reservas mundiais comprovadas de petróleo estão na casa de 800 bilhões de barris e que enquanto a Arábia Saudita, o maior produtor, detém 250 bilhões, os Estados Unidos, principal consumidor, dispõe de apenas 21 bilhões. "Isso significa o aumento da dependência externa, expondo o país a riscos crescentes e daí a razão de 'investirem' tão veementemente no Iraque, por exemplo"3 (CONFERÊNCIA NACIONAL DE BIOENERGIA, 2008, p. 168).

A reação dos Estados Unidos aos ataques às torres gêmeas em 2001, a ocupação do Afeganistão seguida da invasão do Iraque e a execução de Saddam Hussein são uma sucessão de eventos que tem mais razões do que aqueles que ganharam destaque nas agências de notícias ocidentais.

Na guerra contra o Iraque, a motivação explícita de proteger o território dos cidadãos americanos (e de seus aliados) de armas químicas e a motivação implícita de garantir o fornecimento do petróleo exigem refletir sobre algumas observações que ressaltam do cenário imediato produzido por este acontecimento (CASTRO, 2005, p. 33).

Meses após o início da Primavera Árabe, que ocasionou as ações da Otan na Líbia e desencadeou uma guerra civil na Síria, é possível afirmar que há um grande interesse do mundo, em especial dos países desenvolvidos, na instabilidade política do Oriente Médio e na reserva petrolífera da região. "Afinal, a guerra tem sido uma estratégia dos Estados para aumentar seu controle sobre territórios e sobre a riqueza frente a outros Estados" (CASTRO, 2005, p. 33).

Outro geógrafo político que faz uma análise semelhante é John Agnew (AGNEW, 2004, p. 1), para quem a "imaginação geopolítica" moderna, que fomenta o “jogo" por controle político e influência envolvendo os Estados Unidos e seus adversários, marcou profundamente as políticas mundiais em termos de um contexto global abrangente. Neste contexto, "estados competem por poder fora de seus limites, ganham controle (formalmente e informalmente) sobre regiões menos modernas (e sobre seus recursos) e superam outros estados de maior importância numa busca

\footnotetext{
${ }^{3}$ A afirmação do, então, assessor do departamento de cana-de-açúcar e agroenergia do Ministério da Agricultura, Pecuária e Abastacimento (MAPA), José Nilton de Souza Vieira, possivelmente, faz referência aos gastos militares empenhados pelos norte-americanos nas guerras contra o país do Oriente Médio.
} 
mundial por primazia global" (AGNEW, 2004, p. 1, tradução nossa). Em meados de 2008, os Estados Unidos consumiam 25\% do petróleo mundial.

O sistema global vigente, interligado por diversos tipos de redes, com enorme desenvoltura se adapta às condições necessárias à manutenção das estruturas conservadoras. Entre as décadas de 1960 e 1970 ocorre o fortalecimento das discussões sobre a questão ambiental. Especialistas concordam que a dissociação entre a questão energética e a ambiental é prejudicial e que este debate já superou a fase de polêmica teórica para se transformar num problema do cotidiano social que precisa ser enfrentado.

Considerando o fortalecimento do discurso das grandes organizações ambientais transnacionais e a emergência de mudanças na postura de alguns governos locais em relação às legislações sobre o tema, há expectativas que relacionam o aumento do consumo de energia e os efeitos climáticos estimados para o ano de 2030 e concluem que "a sustentabilidade do planeta não é viável"“4 (CONFERÊNCIA NACIONAL DE BIOENERGIA, 2008, p. 185).

Um dos marcos internacionais do tema foi a publicação, em 2007, do $4^{\circ}$ Relatório de Avaliação pelo Painel Intergovernamental sobre Mudanças Climáticas (IPCC), que apresentou problemas emergentes da equação entre o crescimento econômico e das emissões de gás carbônico (CO2) relacionada à queima de combustíveis fósseis. O professor José Goldemberg discute o problema relacionando-o às "agressões antropogênicas" ao meio ambiente, como a poluição urbana, o efeito estufa, além da degradação costeira e marinha, esta relacionada diretamente ao transporte e extração do petróleo. "O homem se tornou uma força de proporção geológica" (GOLDEMBERG, VILLANUEVA, 2003, p. 72).

No final do século XX, só o transporte era responsável por quase um quarto das emissões globais de gás carbônico. Apesar disso, a crise do petróleo na década de 1970 teria feito os países industrializados terem "êxito" em reduzir a dependência dos combustíveis fósseis "por meio de melhorias na eficiência do uso de energia e de mudanças estruturais que os estão levando a se tornarem economias pós-industriais" (GOLDEMBERG, VILLANUEVA, 2003, p. 206).

Uma das principais medidas adotadas pelo governo brasileiro a respeito do tema é o Pró-Álcool. O programa causou mudanças estruturais, seja na questão fundiária ou

\footnotetext{
${ }^{4}$ Afirmação do professor e coordenador do laboratório de Poluição Atmosférica da Faculdade de Medicina (FM) da USP, Paulo Hilário Nascimento Saldívia, durante a Bioconfe.
} 
no padrão de produção de regiões como o Sudeste, Centro-oeste e até o Nordeste. Ainda hoje, a fonte mais considerada para solucionar os problemas específicos dos poluentes gerados pelo transporte é a biomassa, por meio dos combustíveis alternativos (CONFERÊNCIA NACIONAL DE BIOENERGIA, 2008, p. 90; e GOLDEMBERG, VILLANUEVA, p. 130). Os grandes volumes de investimento no desenvolvimento de biocombustíveis e a nova legislação elevando a meta de consumo de biocombustíveis pelos Estados Unidos são algumas das mostras de que a tecnologia ainda deve se desenvolver muito.

Isso pode representar, no entanto, que esta também seja uma questão com tendência a ser globalizada e envolver questões sociais, políticas, econômicas e ambientais complexas ao redor do mundo. A produção de milho nos Estados Unidos, por exemplo, cultivo pelo qual o país produz o etanol, é incapaz de prover o consumo de biocombustível estimado pelo governo do país para 2017. A busca por parceiros, portanto, deve aumentar, assim como a força do discurso relacionado à exploração do potencial agricultável de terras "ociosas” no Brasil, na África e em outros lugares.

Analisada dentro da perspectiva da geopolítica vinculada ao petróleo e à matriz energética do setor de transportes, a América do Sul conta com uma posição privilegiada em relação a outras regiões do mundo. Os principais países da região dispõem de reservas de hidrocarbonetos em volumes variados, com destaque para o Brasil, que a despeito de só recentemente ter alcançado a auto-suficiência em petróleo, conta com a Petrobrás, "uma das 100 maiores empresas do mundo e com atuação em diversos países" (COSTA, 2009, p. 8).

Obviamente, o Pró-Álcool teve uma série de reflexos para o território nacional e causou mudanças na situação política vigente (FERNANDES, WELCH, GONÇALVES, 2010, p. 815). A área plantada e a produção de cana-de-açúcar aumentaram muito por conta da demanda pelo etanol no país, cujo volume equivale ao da oferta de gasolina.

O governo oferece apoio e financiamentos irrestritos aos empresários do setor, que dificilmente amargam prejuízos. Mesmo assim, usinas utilizam mão-de-obra precária. Já houve casos de trabalhadores em situação análoga à da escravidão em atividades da cadeia de produção do setor sucroalcooleiro (HASHIZUME, 2009), que representa 3,65\% do Produto Interno Bruto (PIB) brasileiro. No Estado de São Paulo, pesquisadores se dedicam às pesquisas relacionadas à produção do etanol de segunda geração em escala industrial. 
Outro combustível cuja produção está sendo incentivada pelo poder público nos países sul-americanos é o biodiesel. Colômbia, Argentina, Brasil e Peru possuem políticas públicas, realizam estudos de viabilidade e produzem o biodiesel derivado de diferentes culturas agrícolas.

Motivado por demandas que possuem origens fragmentadas por uma infinidade de fatores que ocorreram em momentos diversos em variados pontos do mundo, o Brasil tornou-se um dos maiores produtores de biodiesel do mundo. O país utiliza óleo extraído da soja como fonte de quase todo o volume do biocombustível produzido. $\mathrm{O}$ temor de que o programa repetisse o efeito da concentração de terras, como ocorreu com o incentivo à produção de etanol era uma das maiores preocupações do governo antes do lançamento do PNPB. O avanço da sojicultura no oeste baiano na forma da expansão de latifúndios pode ser um sinal de que o agronegócio seja o principal favorecido do programa de incentivo ao biodiesel.

\subsection{Adoção das escalas e território}

O panorama traçado tem o objetivo de contribuir para a reflexão sobre o emaranhado de acontecimentos relacionados aos temas abordados e a complexidade de se realizar uma análise que não tente considerá-los dentro da totalidade buscada. Isso porque, para "que determinadas ações se produzam, é necessário que um certo arranjo físico-espacial seja concomitantemente produzido. [...] É claro que há sempre enormes possibilidades de transformar estas práticas e de rearrumar este espaço" (GOMES, 1997, p. 37).

Esta avaliação da situação anterior ao período de análise é importante para ajudar a compreender o processo que se desenrolou em Morro do Chapéu a partir de 2007 e como este alterou o espaço existente, influenciado pelos programas públicos analisados. Para auxiliar nesta tarefa é que a escala local será analisada, esta considerada como "a medida que confere visibilidade ao fenômeno" (CASTRO, 2011, p. 123), “o artifício analítico que dá visibilidade ao real” (CASTRO, 2011, p. 133).

A atenção às dinâmicas promovidas pelos programas públicos em questão para a realidade do município e de algumas localidades específicas é que permite relacioná-las e compará-las. A partir daí é possível também conjeturar sobre as contradições que 
emergem entre as iniciativas na escala local e destas em relação aos efeitos que eram esperados, definidos dentro da burocracia da escala federal. Considerar a escala global, a influência desta para as decisões geradas pelo Estado na esfera federal e para as mudanças produzidas na realidade local também permite refletir sobre as contradições inerentes aos estímulos à produção de energia "limpa" e os efeitos sobre a formação territorial de Morro do Chapéu.

As diversas escalas supõem, portanto, campos de representação a partir dos quais é estabelecida a pertinência do objeto, mas cada escala apenas indica o espaço de referência no qual se pensa a pertinência, mais geralmente a pertinência do sentido atribuído ao objeto definido pelo campo de representação (CASTRO, 2011, p. 134).

As escalas seriam assim a escolha de "uma forma de dividir o espaço, definindo uma realidade percebida/concebida, é uma forma de dar-lhe figuração, uma representação, um ponto de vista que modifica a percepção mesma da natureza deste espaço" e definiriam modelos espaciais de "totalidades sucessivas" (CASTRO, 2011, p. 136). Por outro lado, a partir desta perspectiva, a escala introduziria o problema da "polimorfia do espaço, sendo o jogo de escalas um jogo de relações entre fenômenos de amplitude e natureza diversas" (CASTRO, 2011, p. 138).

\footnotetext{
A flexibilidade espacial institui, portanto, uma dupla questão: a da pertinência das relações como sendo também definida pela pertinência da medida da sua relação com o seu espaço de referência. Este é um problema fundamental na busca de compreensão da articulação de fenômenos em diferentes escalas (CASTRO, 2011, p. 138).
}

Por isso, tentar-se-á considerar as relações estabelecidas entre a escala de elaboração do PNPB e do PAA, a do poder público federal, e da execução dos programas, no caso, a escala local, e "diferenciar os condicionantes" (MORAES, 2000, p. 26) de ambas as iniciativas. Há de serem "consideradas conjunturas distintas, cada uma com seus determinantes e resultados próprios, que se unificam na continuidade cumulativa da apropriação/transformação/construção do espaço” (MORAES, 2000, p. 26).

No caso desta pesquisa, é importante considerar as relações entre os programas públicos citados e as mudanças ocorridas no período entre 2007 e os dias atuais como um dos processos de formação territorial de Morro do Chapéu. Assim, a partir da definição do "espaço como dimensão da realidade" (MORAES, 2000, p. 21), torna-se 
importante apreender a história do "território" (MORAES, 2000, p. 21) em questão e equacioná-la "como um processo" (MORAES, 2000, p. 21), na busca pela gênese de "conjuntos espaciais contemporâneos".

O processo de formação territorial em questão permite verificar que o território de Morro do Chapéu também "não se mantém apenas pelo recurso à força e à violência, envolvendo também instâncias de legitimação do domínio e do poder praticados" (MORAES, 2000, p. 21). Neste sentido

o território é também uma construção política, que deve ser reiterada por meio de pactos e disputas sociais. Até por isso, a formação territorial apresenta ainda uma faceta de estrita elaboração ideológica, resultando em constructos discursivos que comandam tanto a consciência dos lugares quanto sua produção material (MORAES, 2000, p. 22).

Será possível avaliar estes constructos vinculados aos programas públicos analisados e as contradições inerentes àqueles mais à frente. Por enquanto, é recomendável libertar o conceito de território adotado "da confusão com a violência e da restrição à dominação" (SOUZA, 2011, p. 80). Isso porque, mesmo que o território seja:

entendido à escala nacional e em associação com o Estado como grande gestor [...] ele não precisa e nem deve ser reduzido a essa escala ou à associação com a figura do Estado. Territórios existem e são construídos (e desconstruídos) nas mais diversas escalas [...], dentro de escalas temporais as mais diferentes (SOUZA, 2011, p. 80).

Aborda-se, assim, a temática da territorialidade, "uma flexibilização da visão do que seja o território. Aqui o território será um campo de forças, uma teia ou rede de relações sociais que, a par de sua complexidade interna, define, ao mesmo tempo, um limite, uma alteridade" (SOUZA, 2011, p. 86). Torna-se necessário diferenciar o substrato espacial do território, que pode ser verificado na "perpetuação de representações espaciais territorializantes mesmo após a organização espacial original ter se modificado sensivelmente ou entrado em decadência" (SOUZA, 2011, p. 98), como é o caso de alguns processos citados para a área considerada durante a formação territorial do sertão.

Vale ainda considerar que a adoção do sentido de território, aqui, tem como pressuposto que: 
o uso e o controle do território, da mesma maneira que a repartição real de poder, devem ser elevados a um plano de grande relevância também quando da formulação de estratégias de desenvolvimento sócio-espacial em sentido amplo, não meramente econômico-capitalista, isto é, que contribuam para uma maior justiça social e não se limitem a clamar por crescimento econômico e modernização tecnológica (SOUZA, 2011, p. 100).

Paralelamente, é necessário, ainda, avaliar se os programas verificados modificaram de alguma forma a possibilidade dos agricultores entrevistados se deterem "sobre um controle significativo sobre o seu espaço vivido", já que isso é, "para uma coletividade, decisivo" (SOUZA, 2011, p. 111). Isso se torna ainda mais relevante para um estudo que se propõe a avaliar se tais programas trouxeram, de fato, mudanças sociais e políticas para Morro do Chapéu. 


\section{Formação territorial em Morro do Chapéu dos séculos XVI ao XXI}

Após organizar os conceitos adotados é importante dar continuidade ao trabalho de associação das categorias de análise com os processos de formação territorial de Morro do Chapéu para, posteriormente, analisar a evolução das categorias função, forma e estrutura destacadas no processo de destaque da pesquisa.

É possível afirmar que a exploração de minerais preciosos foi a primeira função que os primeiros bandeirantes, homens de confiança da coroa portuguesa, desejaram para os espaços que desbravavam no início da colonização do país. No caso do sertão da Bahia e de Morro do Chapéu não foi diferente. Apesar de haver relatos que dedicam aos jesuítas o pioneirismo na exploração da região onde se localiza atualmente Utinga, a partir de 1551, a maior parte das citações a respeito do início da colonização na região do município é dedicada ao bandeirante João Coelho de Souza.

\footnotetext{
Morro do Chapéu [...] teve início lá pelos idos de 1570 e 1600, quando o bandeirante João Coelho de Souza, estimulado pela pesquisa de outros audazes bandeirantes, abriu uma estrada pelo Paraguaçu em demanda do São Francisco, persuadido, certamente, que o Paraguaçu, pelo seu volume, fosse um afluente desse rio. Baseando-se nos dados conhecidos supõe-se que João Coelho de Souza, subindo o rio Paraguaçu, atingiu as matas do Orobó e dali alcançou as cabeceiras do rio Utinga, subiu a serra da Boa Esperança, atravessou Morro do Chapéu, ainda mata virgem, de onde divisou as serras de Jacobina e para lá se dirigiu em busca de ouro [...] após sofrimentos, fadigas, e inúmeros combates com os indígenas, João Coelho encontrou metais preciosos e organizou um roteiro que antes de morrer mandou entregar a seu irmão Gabriel Soares (CUNEGUNDES, 1981, p. 13).
}

Já Walfrido Moraes registra a passagem de bandeirantes e sertanistas como Fernão Dias Pais, Belchior Dias Moreira, Gabriel Soares, entre outros pela Chapada Diamantina durante o século XVII (MORAES, 1963, p. 8). Há ainda relatos de que já em fins do XVI, "os criadores [de gado] baianos e pernambucanos se encontravam já nos sertões do rio São Francisco" (RIBEIRO, 2006, p. 307), rio do qual alguns afluentes fluem pelo território de Morro do Chapéu, inserindo o município no chamado Vale do rio São Francisco.

A pecuária foi a segunda função pretendida pelo gentio colonial para o sertão e, consequentemente, para Morro do Chapéu. Como fora visto, a coroa portuguesa 
concede as terras nas quais a atividade se desenvolve, fomentando os engenhos de canade-açúcar do Recôncavo baiano, principal função econômica da colônia, responsável pelo desenvolvimento de diversos núcleos habitacionais e o avanço da escravidão no Brasil.

A "expansão da pecuária nas terras mais secas do interior nordestino" teria se dado como um "processo, complementar à zona canavieira" (MORAES, 2000, p. 311). Assim, a atividade "progrediu de uma forma extensiva ocupando [...] o 'sertão de fora' (distinguindo do 'sertão de dentro', de colonização baiana)" (MORAES, 2000, p. 311). Morro do Chapéu, inserido na área do "sertão de dentro", tinha participação ativa na estrutura da pecuária, principal atividade econômica do sertão. Isso mostra a importância da função a qual os grandes latifundiários da capital da colônia destinavam à região que integraria o município. O objetivo era subsidiar o modelo econômico colonial voltado para a exportação de açúcar. A produção de couro também abastecia o mercado externo.

\footnotetext{
Morro do Chapéu, por exemplo, como coisa do passado, com um território vasto, extensas áreas abertas, cobertas a maior parte por pastagens naturais, era um convite ao desenvolvimento da pecuária por preço barato. Bastava uma casa coberta de telhas para o fazendeiro, uma casa de taipa coberta de sapé destinada ao vaqueiro, um curral de madeira no oitão da casa, uma área cercada para prender os cavalos do campo, quando não estão soltos para pastarem na malhada; à tarde o encurralamento das vacas para no dia seguinte tirar o leite e coalhar em grandes potes de barro, fazer o requeijão, vender nas feiras dos povoados mais próximos para a compra dos gêneros necessários à manutenção da semana. Vida boa e folgada [sic] (CUNEGUNDES, 1981, p. 103).
}

Relacionando o relato de Jubilino Cunegundes, político influente do município, às informações obtidas junto aos agricultores familiares de Morro do Chapéu e suas famílias, que participaram do Programa de Aquisição de Alimentos (PAA) ou do Programa Nacional de Produção e Uso de Biodiesel (PNPB), cujas narrativas foram incorporadas nesta pesquisa, especialmente as pessoas mais antigas, é possível conjeturar a respeito das formas espaciais daquela região antes do século XX.

Até então, as cercas de madeira serviam apenas para o descanso dos animais e a proteção dos roçados dos "sitiantes" (WOORTMANN, E.; WOORTMANN, K.; 1997, p. 17). Estes espaços cercados se limitavam às áreas anexas às residências e os animais eram criados soltos durante o dia em amplas áreas de propriedades cujos limites eram dados por formas naturais, como córregos, rios, montanhas, ou uma simples árvore. $\mathrm{Na}$ 
segunda metade do século XIX a estrutura fundiária transforma-se em um novo processo, alterando permanentemente as formas do espaço no local.

A partir de 1850, com a promulgação da Lei das Terras, que instituiu a propriedade privada mercantil, intensificaram-se as disputas. Os sitiantes eram posseiros e não proprietários [...]. Para os sitiantes, os direitos sobre a terra não passavam pelo cartório, mas derivavam do trabalho. Era a terra de trabalho, expressão que encerra um conjunto de significados (WOORTMANN, E.; WOORTMANN, K.; 1997, p. 19).

No entanto, "não era no campo que os agentes do Estado buscavam vestígios e sim nos cartórios" (WOORTMANN, E.; WOORTMANN, K.; 1997, p. 21). As 25 primeiras propriedades de Morro do Chapéu teriam sido registradas apenas com a menção de "seus limites, sem especificar a quantidade de hectares de cada uma" (CUNEGUNDES, 1981, p. 105). É a partir da virada do século XIX que diversos núcleos populacionais passam a se desenvolver na região do atual município, entre eles a fazenda Gameleira, de propriedade do Conde da Ponte, que se consolidaria como sede de Morro do Chapéu.

\footnotetext{
Através de sucessivas transmissões, por inventários e vendas, os sucessores foram contemplados nessas propriedades, recebendo uma parte de terra em comum com outros possuidores, sem dimensionar a área herdada ou comprada, ficando, por isso, cada um com uma parte ideal, podendo, desse modo, dispor de qualquer quantidade, sem que os demais donos pudessem reclamar, a não ser que lançassem mãos do recurso indicado na lei - a demarcação e divisão processo caríssimo. Aproveitando-se dessa situação, vendiam o direito que possuíam na fazenda $\mathrm{X}$, enquanto que o comprador inteligentemente, na posse de seus direitos, fazia várias vendagens, lucrando bastante (CUNEGUNDES, 1981, p. 105).
}

Após 1841, com o desenvolvimento da freguesia, novos compradores, "inclusive alguns estrangeiros", fixam residência e passam a comprar "grandes áreas de terras a partir das margens dos rios" (CUNEGUNDES, 1981, p. 20). As cercas das propriedades já são mais visíveis nas formas da Vila de Morro do Chapéu, criada em 1864, emancipada e desmembrada de Jacobina - um dos municípios mais antigos da Bahia. A partir daí as formas do município serão permanentemente marcadas pela subdivisão das propriedades privadas.

Além das famílias proprietárias, um grande volume de pessoas passou a se aglomerar a partir das sedes de fazendas e nas proximidades, criando outras tantas vilas e novos povoados. Estes habitantes tinham origens diversas, entre elas, descendentes de indígenas, de colonizadores, escravos e trabalhadores assalariados. Em relação ao 
processo de expansão da pecuária, que se dá por meio de formas e funções que também marcam permanentemente as estruturas do sertão e de Morro do Chapéu, é importante ressaltar que:

a força do trabalho envolvida na montagem de todo esse sistema foi o escravo indígena, e por isso as sociedades autóctones conheceram aí rápido decréscimo populacional, o que levou essa região a experimentar as pioneiras entradas maciças de africanos, exatamente no período enfocado (MORAES, 2000, p. 311).

Assim, o sertão baiano também foi palco da fuga de negros e da "formação de bandos" (MORAES, 2000, p. 376) que datam desde meados do século XVI até o final do século. A existência de comunidades de remanescentes quilombolas na atualidade é prova da existência de uma grande diversidade "de comunidades africanas no vale do São Francisco" (MORAES, 2000, p. 377), incluindo o Morro do Chapéu.

Portanto, é a pecuária a responsável pela quase total dizimação dos indígenas, pela absorção de um grande volume de escravos e pela origem da agricultura nos sertões baianos e nordestinos. Manuel Correia de Andrade também dedica o avanço do "movimento povoador" do interior nordestino aos "vaqueiros, muitas vezes escravos", e aos "posseiros" que não dispunham de prestígio em Salvador, nem das "habilidades necessárias para obterem" sesmarias. "Reconhecendo o domínio da terra aos mesmos e tornando-se seus foreiros, estabeleciam-se com o curral e as reses" (ANDRADE, 1998, p.168).

Ao final do século XIX Morro do Chapéu exercia uma função estratégica dentro do processo de desenvolvimento da pecuária, tanto na escala regional quanto na ligação com a expansão da atividade no Centro-Oeste. A cidade é citada no relato memorial de Claudionor de Oliveira Queiroz, advogado nascido no fim do século XIX, cuja família mudara para Morro do Chapéu fugindo dos conflitos armados na Chapada Velha, e que combateu jagunços inimigos, forças policiais do governo estadual e até a Coluna Prestes ao lado do primo, o coronel Horácio de Matos.

Era o tempo das boiadas. De Goiás e de Minas Gerais, os boiadeiros faziam o comércio de gado com a Bahia. Atravessavam o São Francisco em Canoas (atual Igarité) e despejavam todo o gado nos tabuleiros de Morro do Chapéu para depois da invernada serem levados à Feira de Santana (QUEIROZ, 1985, 17). 
$\mathrm{Na}$ época, a mão-de-obra empregada, pelo menos para o transporte do gado, já era assalariada. Citando o caso do filho do "Capitãozinho" Paula Ribeiro, Heliodoro de Paula Ribeiro, o autor afirma que:

Heliodoro fez atravessar o gado [para a Bahia], comprou-o todo fiado, e abusando do crédito do pai, concedeu em seu nome ordens de pagamento em favor dos boiadeiros, a serem pagas em Salvador pelos comerciantes que negociavam com o velho Capitãozinho. (QUEIROZ, 1985, 17)

Paralelamente, como fora visto, a agricultura se desenvolve junto aos currais, representando mais uma função estabelecida pelos moradores para o espaço, que, no caso, necessitavam cultivar gêneros alimentícios para a subsistência, dadas as grandes distâncias dos centros comerciais e a dificuldade de acesso, do que uma função econômica originada em outras esferas de decisão a ser aplicada no local.

No caso de Morro do Chapéu, a oferta de água ofereceu condições vantajosas àqueles que se instalaram nas margens dos rios para trabalhar com o gado, favorecendo também a produção agrícola. A restrição de acesso à água teria sido um dos motivos para o descontentamento de indígenas, o que motivou numerosos conflitos ao longo nos primeiros séculos de colonização. Sendo um dos municípios de maiores altitudes do interior da Bahia, Morro do Chapéu possui nascentes e rios de quatro bacias hidrográficas diferentes, a do rio Utinga, a do Salitre, Jacuípe e Jacaré (ROCHA, COSTA, 1995a). Tal arranjo fez o município ficar conhecido como a "a caixa d'água da Bahia".

Baseando-se nas definições de Manuel Correia de Andrade, é possível inserir Morro do Chapéu na definição de "Sertão" adotada pelo autor, apesar da grande variação de altitude dentro do território do município. Morro do Chapéu pode ser assim compreendido por possuir alguns dos "amplos pediplanos existentes" em estados do Nordeste. O pediplano possui as características de ser

cortado por vales de rios intermitentes, que correm apenas alguns dias por ano, após a queda dos grandes aguaceiros de verão e que têm, em geral, leitos muito largos e pouco profundos, separados por suaves interflúvios. Os solos são muito rasos, às vezes até inexistentes, uma vez que aparecem grandes afloramentos rochosos, chamados localmente de lajedos. Nos lugares mais baixos, para onde o material de menor textura, desagregado das rochas é carregado pelas enxurradas, formam-se deposições arenosas (ANDRADE, 1998, p. 41). 
Sob a influência das duas atividades econômicas anteriormente citadas, Morro do Chapéu era um dos principais núcleos populacionais "ponderáveis [instalados e que se desenvolveram na] área do sertão de $\operatorname{cima}^{5 "}$ (MORAES, 1963, p. 15) durante o século XVIII.

Aquela que foi considerada a primeira função destinada à região no período do desbravamento foi se desenvolver em Morro do Chapéu apenas a partir do século XIX, alterando permanentemente as formas de algumas áreas e a estrutura do município. $\mathrm{O}$ garimpo de diamantes teria começado em 1841 e durado até 1932 no Morro do Chapéu. De acordo com estudo do CPRM (Serviço Geológico do Brasil), a prática se deu principalmente na sede municipal, na serra do Martim Afonso e, "destacadamente, na vila do Ventura" (ROCHA; PEDREIRA, 2009).

Relatos orais que guardam a memória da população da cidade até hoje enumeram aos milhares os habitantes da vila do "Ventura" no auge do garimpo de diamantes. Após o período, o lugar, cujo solo foi sucessivamente revirado ao longo das décadas e que teve alterado o curso do principal rio que cortava a vila, entrou em vertiginoso declínio até o quase completo abandono. As marcas deixadas pelo garimpo para as formas da vila do Ventura, da sede e de outras localidades também se tornaram permanentemente visíveis.

O crescimento econômico do distrito do Ventura é tamanho que, no auge da atividade mineradora, o distrito chega a disputar a posição de sede do município com o local onde até hoje está instalado o centro econômico e administrativo de Morro do Chapéu. Em função da extração de "carbonatos e diamantes" (CUNEGUNDES, 1981, p. 37) o comércio de pedras passa a ter uma representatividade ainda maior que a da pecuária para a economia da Vila, que é elevada à condição de cidade de Morro do Chapéu em 1909, gerando, como efeito para a estrutura política local, disputas entre diferentes grupos.

A região da Chapada Diamantina vai experimentar com mais intensidade durante o início do século XX o processo pelo qual passara o interior de Minas Gerais a partir do século XVIII ${ }^{6}$. A atividade mineradora daria sobrevida ao sertão, após o

\footnotetext{
${ }^{5}$ Termo utilizado, possivelmente, para diferenciar a área do piemonte da Chapada Diamantina do restante da região. Vale lembrar que além da região do piemonte, há ainda a área conhecida como Chapada Velha, a oeste, no limite com o rio São Francisco.

${ }^{6}$ Antes do início da mineração na Bahia, a área de Morro do Chapéu já estava ligada à região das Minas Gerais por conta do fornecimento de animais e mantimentos. Os fluxos de mercadorias e pessoas nos trechos baianos do caminho, que atravessava a Serra do Sincorá e passava pela vila de Ventura, e que seria depois conhecido como a parte baiana da estrada real, se intensificaram após 1839, quando se
} 
"deslocamento do polo dinâmico da economia colonial do nordeste para o centro-sul, a partir da decadência relativa da atividade açucareira nordestina" e do "deslocamento da sede do poder central de Salvador para o Rio de Janeiro", medidas que provocam modificações que "alteram o curso da formação territorial” brasileira (COSTA, 1991, p. $31)$.

Em Morro do Chapéu, as serras que possuíam garimpos se tornam mais valorizadas do que antigos distritos como o de Riachão de Utinga e Brejinho, que "possuíam as maiores reservas de água e os campos de altitude mais propícios para a pecuária" (SAMPAIO, 2009, p. 94). De acordo com o autor, com a alteração da principal atividade econômica da Chapada Diamantina, da pecuária para o garimpo:

\begin{abstract}
as terras perderam muito do seu valor e muitas grandes propriedades foram desintegradas por más administrações ou por distribuição de heranças. Estas terras fragmentadas e na sua maioria com pastagens degradadas, foram compradas pelos emergentes enriquecidos pelo garimpo [...]. Com a ascensão de uma nova elite econômica e política do município houve também um reordenamento fundiário. Os antigos pecuaristas, que também representavam o grupo político decadente, foram paulatinamente afastados para as áreas do Município de Morro do Chapéu com vocação exclusiva de agricultura. Ou seja, à medida que a pecuária extensiva deixava de ser a principal atividade econômica da região, muitos proprietários se afastaram das fazendas abandonadas, as pastagens e as construções se degradavam. Essa mudança se deu mais intensamente com a seca que atingiu a região de 1898 a 1900 (SAMPAIO, 2009, p. 94-95).
\end{abstract}

A evolução da estrutura de vias terrestres no território de Morro do Chapéu ao longo dos séculos também marca as formas do município, funções de diferentes localidades e a estrutura produtiva. As estradas de terra vicinais se ramificam conforme as fazendas são divididas e surgem novas moradias e estas dão lugar a rodovias. Por outro lado, a redução gradual do fluxo de mercadorias, principalmente do gado e das pedras preciosas, e de pessoas dedicadas às atividades relacionadas a estes produtos faz praticamente desaparecer os trechos da estrada boiadeira e da estrada real que atravessavam o município.

Em meados do século XX a estrutura produtiva do Nordeste ainda era marcada pela herança colonial e baixo nível de industrialização. Na zona rural predominavam “os latifúndios improdutivos (basicamente no sertão) [e] milhares de minifúndios, pequenas unidades de subsistência, em geral, incapazes de prover as necessidades

descobriu diamantes num lugar próximo à cidade de Gentio do Ouro (BA), na Chapada Velha. As primeiras descobertas foram superadas pelos achados em outros rios da região, especialmente onde localizam-se as cidades de Lençóis e Mucugê (BA) e no Ventura. 
mínimas de uma família" (COSTA, 1991, p. 56). Neste contexto surge a Superintendência do Desenvolvimento do Nordeste (Sudene) $)^{7}$. O órgão teria papel importante como parte das políticas públicas territoriais a partir da década de 1950, como subsidiário da "política econômica" capitalista. E representou mudanças, mesmo que, aparentemente, num nível superficial (COSTA, 1991, p. 59), para a região.

A Sudene pode ser compreendida como uma "rede institucionalizada geografizada" objetiva (COSTA, 1991, p. 75), que também exerce influência sobre "redes hierarquizadas sob a forma de infra-estrutura" (COSTA, 1991, p. 75), como a rede representada pelo sistema viário nacional. O modelo de desenvolvimento proposto pelo órgão federal, criado em 1959, previa a reformulação da política de aproveitamento dos solos, medidas preventivas aos efeitos das secas, a intensificação de investimentos industriais, migração da população para outras áreas, entre outros (BRASIL, 1967, p. 714). O primeiro Plano Diretor de Desenvolvimento Econômico e Social do Nordeste, elaborado pela Sudene já dava destaque à necessidade de fortalecer a rede de transporte rodoviário, executar "trabalhos de conservação [...] para evitar a demora e o encarecimento da operação de transporte" (BRASIL, 1966, p. 40) e o favorecimento aos "serviços de pavimentação" (BRASIL, 1966, p. 41). A partir daí a atenção ao incentivo às rodovias no Nordeste não sairia mais da pauta do órgão (BRASIL, 2011, p. 28).

Nos últimos anos, a Bahia, assim como todo o Nordeste, atravessa um novo processo de modernização impulsionado pelo crescimento do país e pela própria situação de exclusão econômica e social regional. No caso baiano, a indústria petroleira ganhou força no Recôncavo e a soja preenche cada vez mais espaços no oeste do Estado. A indústria automotiva, atraída por incentivos fiscais, instalou um polo industrial em Camaçari (BA), como alternativa ao Sul e Sudeste, cujos encargos trabalhistas encareceram o custo da mão-de-obra e reduzem as altas margens de lucro do setor no país, as maiores da indústria em todo o mundo.

\footnotetext{
${ }^{7}$ O surgimento da Sudene é resultado de uma sucessão de órgãos e tentativas do governo em lidar com a repercussão das sucessivas calamidades sociais provocadas pela seca no sertão e promover "o desenvolvimento do Vale do São Francisco" (COSTA, 1991, p.50). Alguns destes órgãos, no entanto, eram controlados pelas oligarquias da região, que se apoderavam dos recursos remetidos pelo Estado para o combate da seca, ou seja, é "gente que ganha com a seca, porque ela significa muito dinheiro do governo chegando para o comércio, para financiar as frentes de trabalho etc" (FURTADO, 1998, p. 25). Isso transformaria as secas em um negócio para estes grupos.
} 


\subsection{Organização dos territórios-rede no município}

São numerosos os núcleos populacionais que passam a se desenvolver, especialmente, a partir do século XX em Morro do Chapéu. É possível citar ao noroeste o de Umburaninhas, ao norte, Tamboril, Brejões, Icó e Mônica, a nordeste, Queimada do Canto e Flores, a leste, Dias Coelho, Fedegosos e Rosa Benta, a sudeste, Gameleira, Ponta D’água e Ventura, ao sul, Duas Barras, Lagoa Nova, Distoque, Santa Úrsula, a sudoeste, Lagoinha, e a oeste, Velame, São Rafael e Tareco. Juntos estes povoados e as áreas rurais no entorno reúnem na atualidade cerca de 17,5 mil habitantes que vivem na zona rural de Morro do Chapéu. O mesmo volume de moradores, aproximadamente, habita a sede do município ${ }^{8}$.

Em relação às formas atuais do território fica evidente a diferenciação entre os espaços da sede do município, dos povoados e das "roças", interligados pelos caminhos terrestres. A análise realizada propõe considerar, principalmente, os territórios de três povoados de Morro do Chapéu, além da sede do município. Tratam-se das comunidades do Icó, Velame e Fedegosos.

Por possuir algumas das terras mais valorizadas do município, Fedegosos (Figuras 2.1.1 e 2.1.2) pode ser considerado um dos povoados mais desenvolvidos de Morro do Chapéu. Possui escolas, casa de farinha, fábrica de blocos e uma feira dominical regular que acontece no dia seguinte ao último dia de feira da sede - as sextas e sábados. A localidade está numa área que apresenta clima tropical subúmido (ROCHA, COSTA, 1995d), abastecida pela bacia do rio Jacuípe e é considerada favorecida entre as demais pelo volume favorável de chuvas. Isso promove a diversidade de culturas agrícolas produzidas, além da criação de gado, e melhora sua produtividade.

\footnotetext{
${ }^{8}$ A estimativa de população do município, publicada no Diário Oficial da União, em 31 de agosto de 2011, com data de referência em 01/07/2011, era de 35.208 pessoas, de acordo com o Instituto Brasileiro de Geografia e Estatística (IBGE).
} 


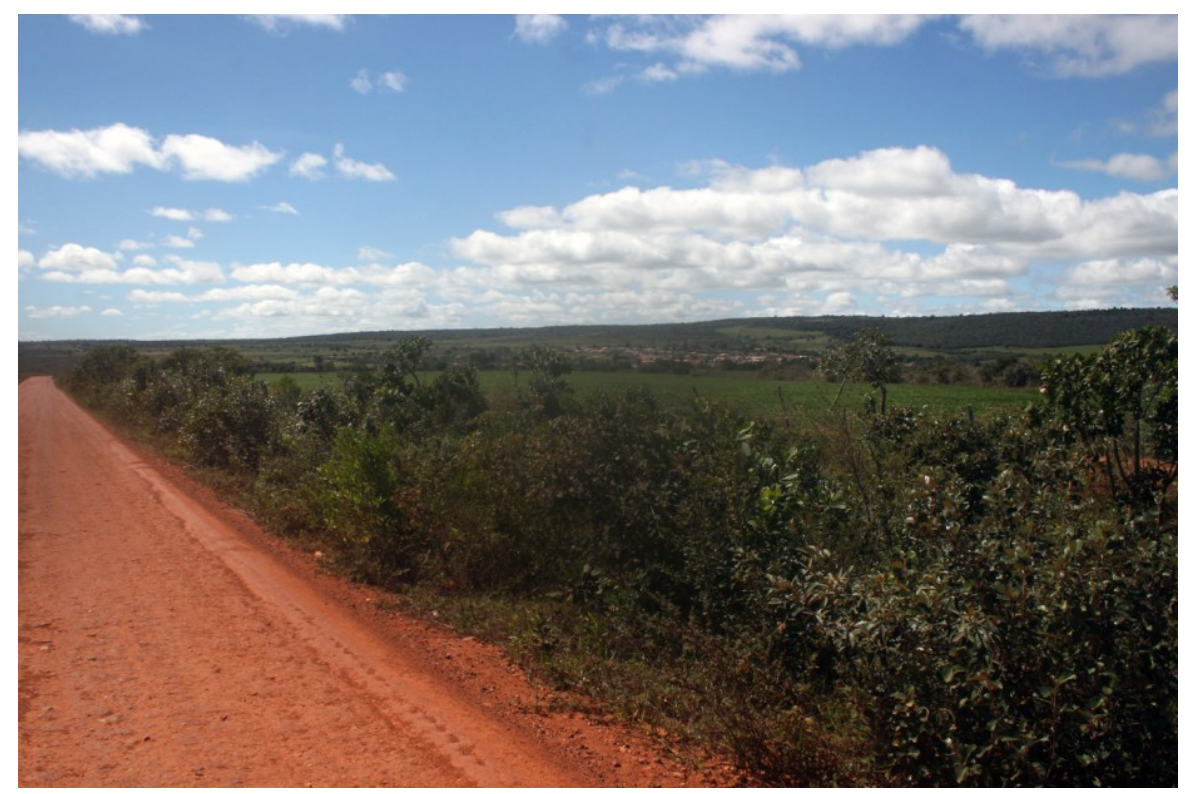

Figura 2.1.1 - Vista do povoado de Fedegosos (ao fundo), em Morro do Chapéu. Localidade difere das demais analisadas por conta da maior incidência de chuvas. Foto: Vinicius Morende, em 03/07/2011

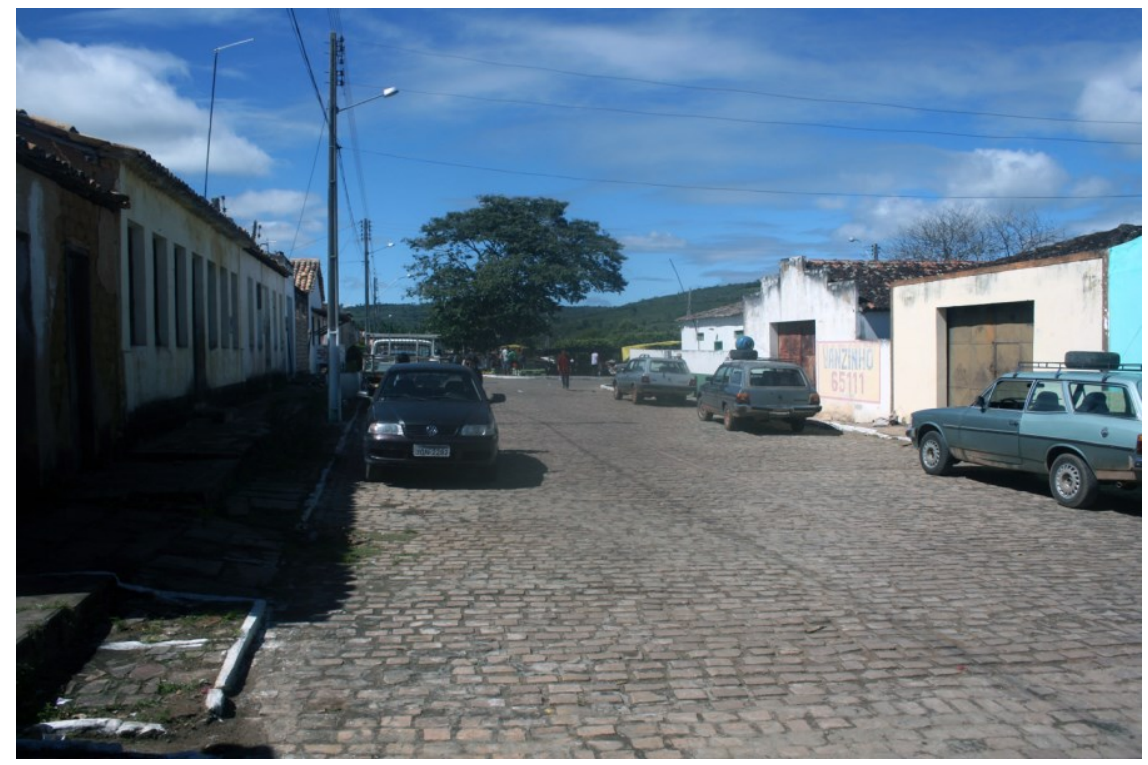

Figura 2.1.2 - Dia de domingo no povoado de Fedegosos, em Morro do Chapéu. Ao fundo a praça principal, onde ocorre a feira semanal. Foto: Vinicius Morende, em 03/07/2011

Assim como Fedegosos, o Icó (Figuras 2.1.3 e 2.1.4) é um colégio eleitoral importante de Morro do Chapéu e um dos distritos mais populosos do município. Talvez, por isso, tenha conseguido investimentos públicos com alguma regularidade ao longo das últimas décadas. A localidade possui escolas, igrejas, poço artesiano comunitário, além de comércio para prover o consumo básico dos habitantes. Ao 
contrário de Fedegosos, no entanto, apresenta clima tropical de altitude quente, numa área sob influencia do clima semi-árido quente (ROCHA, COSTA, 1995d), já inserido na região a qual os moradores costumam se referir como de caatinga, sem a proximidade de água que flui na superfície.
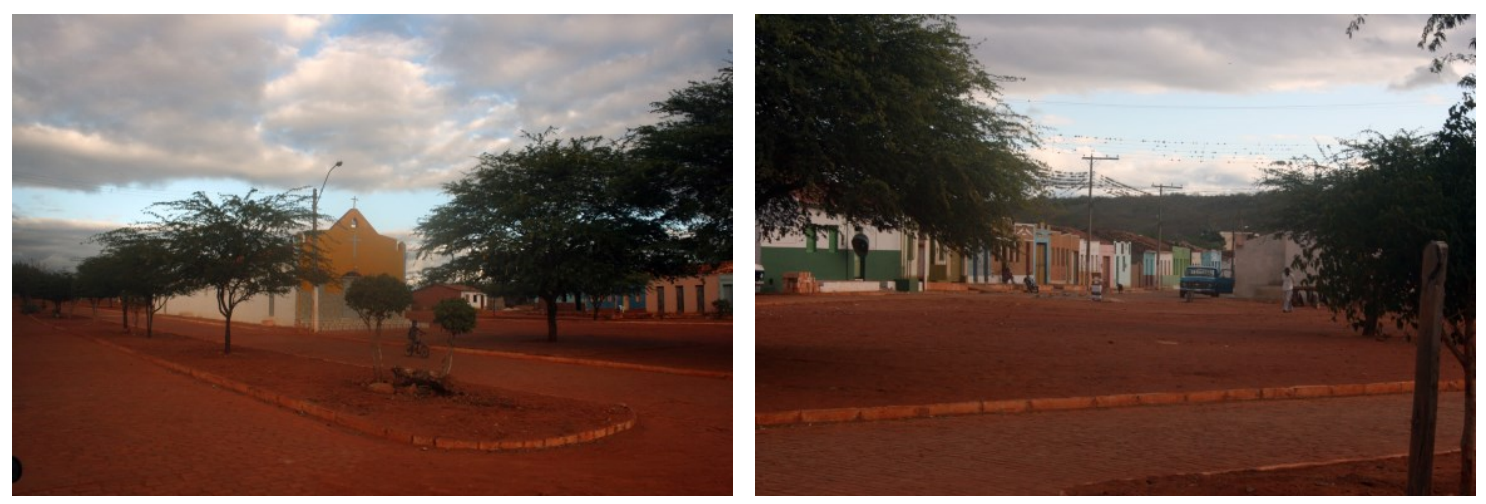

Figuras 2.1.3 (esq.) e 2.1.4 - Praça da igreja matriz do povoado do Icó (esq.) e residências alinhadas a partir da construção, em direção à principal via de acesso ao lugar. A expansão do povoado seguiu o mesmo padrão que a sede do município: a partir da igreja. Foto: Vinicius Morende, em 02/07/2011.

A localidade chamada Velame será considerada junto ao lugarejo vizinho, de nome Malhada de Areia e, indiretamente, como conjunto que forma associado aos povoados vizinhos do limite a oeste de Morro do Chapéu. Ambos estão situados na região da vereda do Romão Gramacho, limite ocidental de Morro do Chapéu. Os vilarejos e parte da vereda foram os últimos a resistir à emancipação de vastas áreas da freguesia, que formou novas cidades que integram o "território de identidade" O rio Jacaré que também dá nome à vereda é provedor da agricultura irrigada desenvolvida na área nos últimos anos como alternativa ao processo de desertificação que se dá na parte ocidental daquele território.

O Velame é o povoado com menor estrutura econômica entre os três estudados. A vila se desenvolveu, de acordo com relatos, a partir de um grupo de escravos da fazenda São Rafael, uma das mais antigas do município. Atualmente um povoado, o lugar dista alguns quilômetros.

\footnotetext{
${ }^{9}$ É importante ressaltar que este conceito, no caso da Bahia, agrupa municípios de acordo com os aspectos histórico, cultural, geoambiental, político-institucional, econômico e de mobilidade (ESTADO DA BAHIA, 2011, p. 3) e insere Morro do Chapéu como o mais setentrional do território da Chapada Diamantina. Além do território de Irecê, o município faz limite com outros três territórios de identidade do Estado: o do Piemonte do Paraguaçu, do Piemonte da Diamantina e do Sertão do São Francisco (BAHIA, 2007).
} 
As estradas são os caminhos que permitem o acesso aos três povoados analisados e à sede de Morro do Chapéu, assim como à maior parte dos núcleos habitacionais do município. Atualmente, as cercas de arame farpado limitam a totalidade dos principais trajetos e chegam a cruzar os caminhos em alguns ramos, interceptando paisagens que se tornaram privadas. Nas partes onde elas deixam de, praticamente, se sobrepor, denunciando a fragmentação de antigas propriedades, exibem áreas de conservação, vastos pastos, terras em "pousio"10 e culturas agrícolas.

De acordo com os aspectos socioeconômicos suscitados por um levantamento geológico de Morro do Chapéu apresentado em 1997 (ROCHA, 1997, p. 5), a agricultura e a pecuária constituem as principais atividades econômicas da área.

\begin{abstract}
A obtenção de carvão vegetal tem sido praticada em larga escala na região, embora não existam cuidados com atividades de reflorestamentos. A extração mineral é limitada a garimpos de barita na borda oriental da Bacia de Irecê, e de diamantes na região de Morro do Chapéu, onde também há produção de material para construção civil (paralelepípedo e pedra britada). A atividade industrial está limitada a uma cerâmica em Morro do Chapéu, e a uma unidade para produção de corretivo de solo nas proximidades da cidade de América Dourada (ROCHA, 1997, p. 6).
\end{abstract}

Mesmo após perder parte do território da antiga freguesia, Morro do Chapéu consegue preservar diversas localidades onde se concentram os fluxos comerciais e informacionais de microrregiões dentro do território do município, e até hoje se constitui como uma das cidades mais extensas do estado da Bahia. A estrutura econômica, que também é reflexo das dinâmicas daqueles fluxos, consolida a sede como o principal centro econômico do município, que passa a concentrar a administração pública, a representação do poder judiciário, o sistema financeiro entre outros serviços públicos e privados. Os povoados consolidam-se como "nós" (CASTELLS, 2004, p. 3) da estrutura econômica - e política -, centralizando diversos tipos de relações com numerosas propriedades que os rodeiam, enquanto estabelecem relações com a sede do município e as sedes das cidades vizinhas.

No caso de quem vive no povoado do Icó, por exemplo, a feira semanal, evento que reúne produtores rurais das imediações e promove o comércio de diversas mercadorias entre os habitantes da região, é realizada na sede da cidade mais próxima, Várzea Nova - emancipada do município de Jacobina em 1985 (INSTITUTO BRASILEIRO DE GEOGRAFIA E ESTATÍSTICA, 2012). Da mesma forma a feira

\footnotetext{
${ }^{10}$ Termo que designa as áreas em repouso.
} 
mais próxima ao Velame é a da vizinha Cafarnaum - desmembrada de Morro do Chapéu em 1956 (INSTITUTO BRASILEIRO DE GEOGRAFIA E ESTATÍSTICA, 2012). Apesar de Fedegosos possuir feira semanal, como já foi visto, os habitantes do povoado realizam diversas relações econômicas com o município vizinho de Miguel Calmon.

Como algumas das relações econômicas dos habitantes da zona rural, representadas aqui pela feira semanal, se dão em relação ao centro urbano mais próximo, por conta da extensão do território de Morro do Chapéu, não há habitantes de cidades vizinhas que realizem, habitualmente, a "feira", ou as compras, na sede do município. Por outro lado, como Morro do Chapéu ainda representa um centro econômico e político da microrregião na qual está inserido - que pode ser considerada pelo conjunto de municípios que se emanciparam a partir do território da antiga freguesia (Figura 2.1.5) - há agricultores e artesãos de outras cidades que vão vender a produção na feira do município.

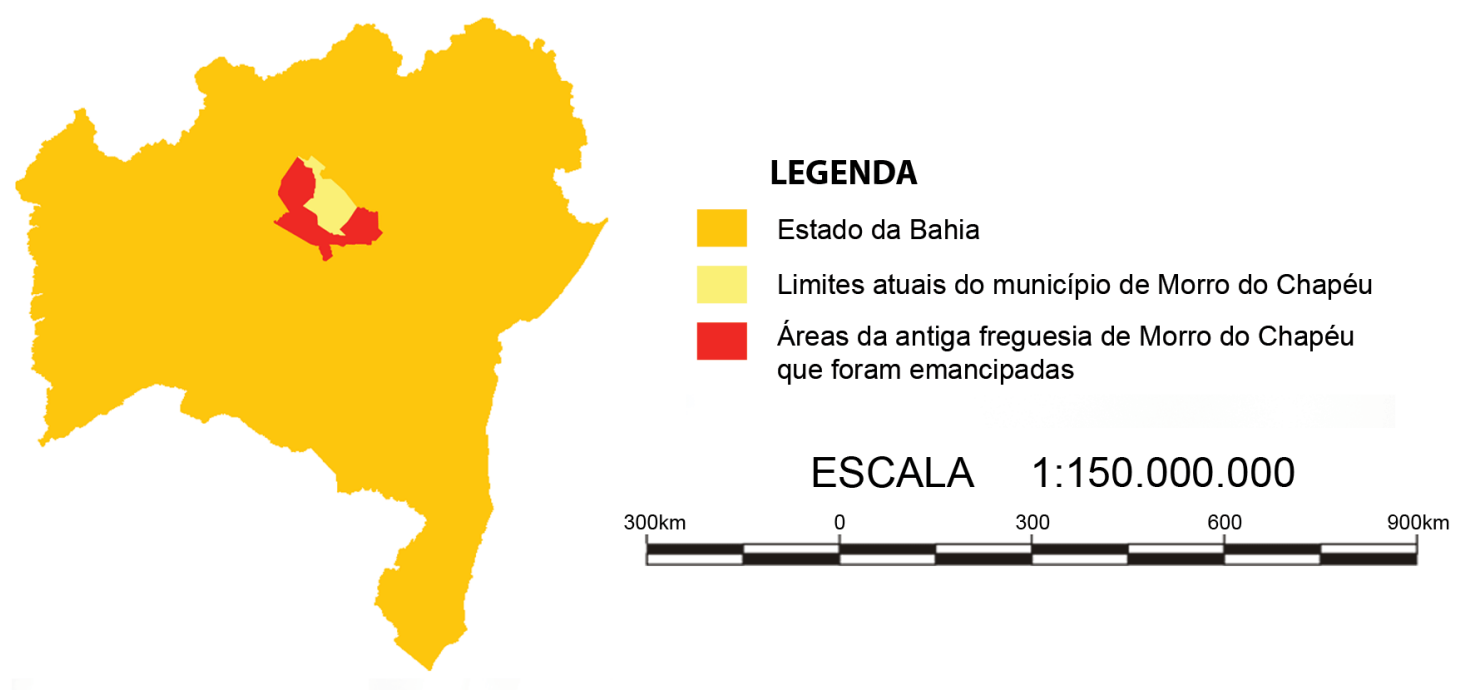

Figura 2.1.5 - Mapa ilustrativo dos limites do município Morro do Chapéu e da área da antiga freguesia, com as regiões que obtiveram a emancipação política. Elaboração: Vinicius Morende.

A descrição destes aspectos espaciais de Morro do Chapéu e dos povoados visitados torna-se importante na tentativa de estabelecer uma "ponte conceitual entre o território" e a "rede", ou o "território-rede" analisado (SOUZA, 2011, p. 93). 
Trata-se, essa ponte conceitual, ao mesmo tempo de uma ponte entre escalas ou níveis de análise: o território descontínuo associa-se a um nível de tratamento onde, aparecendo os nós como pontos adimensionais, não se coloca evidentemente a questão de investigar a estrutura interna desses nós, ao passo que, à escala do território contínuo, que é uma superfície e não um ponto, a estrutura espacial interna precisa ser considerada (SOUZA, 2011, p. 93).

Velame, Icó, Fedegosos e a sede da cidade podem ser analisados como territórios descontínuos que fazem parte de um "território contínuo" (SOUZA, 2011, p. 93), que é conectado em um território-rede, de Morro do Chapéu. A adoção do conceito contribui para superar as limitações de considerar a "exclusividade de um poder em relação a um dado território" e do discurso "de que os territórios são entidades que se justapõe contiguamente, mas não se superpõem” (SOUZA, 2011, p. 94).

Não apenas o que existe, quase sempre, é uma superposição de diversos territórios, com formas variadas e limites não-coincidentes, como, ainda por cima, podem existir contradições entre as diversas territorialidades, por conta dos atritos e contradições existentes entre os respectivos poderes (SOUZA, 2011, p. 94).

Dentro da estrutura econômica da região em que Morro do Chapéu está inserido, por exemplo, é possível verificar a representatividade histórica da cultura da mamona, uma das culturas agrícolas mais presentes ao longo das últimas décadas (Figura 2.1.6). Numa perspectiva dimensional é possível estabelecer até mesmo um território-rede desta cultura, formado pelos espaços rurais que produzem a oleaginosa, os atores envolvidos com a cadeia, os fluxos de circulação dos grãos, atores e recursos, entre outros elementos. Isso possibilitaria falar até mesmo do poder da influência da cultura da mamona na região de Morro do Chapéu, ou do território de identidade de Irecê, pelo menos nas últimas três décadas. 


\section{Mamona}

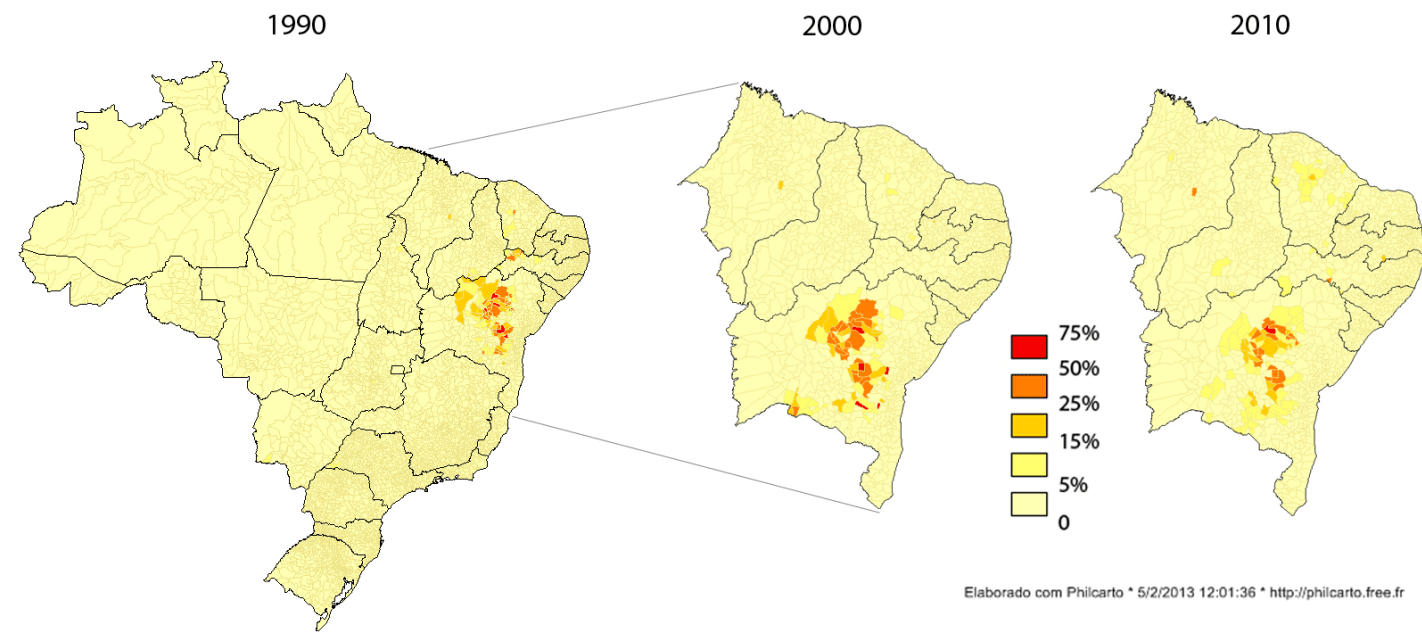

Figura 2.1.6 - Evolução histórica da relação entre a área plantada com mamona e o total de lavouras temporárias nos municípios do Brasil e do Nordeste. O tom mais escuro na legenda representa os municípios que possuíam mais de $50 \%$ das áreas cultivadas com culturas temporárias dedicadas à mamona; o tom mais claro representa os municípios que possuem $5 \%$ ou menos de áreas ocupadas com a cultura. A região de Morro do Chapéu e Irecê aparece como a mais dedicada ao cultivo da cultura no país. Fonte: Sidra/IBGE. Elaboração: Vinicius Morende.

As quatro localidades analisadas de Morro do Chapéu podem ser consideradas as mais influenciadas por esta territorialidade, especialmente a partir de 2007. A região da qual o Velame faz parte é historicamente a principal região produtora de mamona do município e integra a principal região produtora da oleaginosa do país. A cultura, originária da Índia, teria sido introduzida no Brasil a partir da colonização portuguesa (SANTOS, J., 2009, p. 33).

Em 1990, a produção [de mamona] da Bahia foi de 98.766 toneladas (67,8\% da produção nacional). No período de 1990 a 2006, a sua produção aumentou $2,9 \%$ a.a., aumentando a concentração neste estado. A maior produção da Bahia ocorreu em 2005, com 130.240 t. No entanto, em 2006, houve queda de $31,62 \%$ em relação a 1990, com 67.534 t. Mesmo assim, a sua participação foi de $72,2 \%$ da produção brasileira. (SANTOS, J., 2009, p. 36-37)

O engenheiro agrônomo Fabrício Amorim, natural de Vitória da Conquista (BA), diretor operacional da Coopaf, a principal cooperativa de trabalhadores da agricultura familiar do município, afirma que a mamona historicamente foi a segunda cultura mais cultivada na região de Irecê da qual é possível incluir esta área oeste de Morro do Chapéu, por conta da similaridade de aspectos físicos e humanos. O feijão era a principal cultura. "A Bahia sempre foi a grande produtora de mamona no Brasil, destinada à ricinoquímica e esta região de Irecê era uma região que tinha $80 \%$ da 
produção da Bahia, praticamente" (Fabrício Amorim, 2011, residência do entrevistado). Ainda de acordo com o agrônomo, "até 1994 o Brasil foi o maior produtor de mamona do mundo, a partir daí foi superado. De lá pra cá o preço só despencou com a oferta de mais óleo no mercado" (Fabrício Amorim, 2011, residência do entrevistado).

\begin{abstract}
Morro do Chapéu tem duas partes, uma semi-árida e outra mais alta onde está situada a sede da cidade. A região que mais produz mamona é a parte de caatinga, onde o clima é mais propício para o desenvolvimento da cultura. É o lado que está a oeste, em direção a Irecê, Malhada de Areia, Espinheiro, Velame 1 e 2, uma área que já está próxima de Cafarnaum. Esta é uma das melhores regiões para a produção de mamona. Tem um solo bastante apropriado e com uma grande riqueza mineral. E tem outra região, que está aqui próximo de Jacobina, que é a região de Icó e Brejões. Lá já tem uma produção menos expressiva, que está iniciando, não é como esta parte a oeste, mas tem produção significativa, que mostra um bom potencial (Fabrício Amorim, 2011, residência do entrevistado).
\end{abstract}

A partir deste ponto, torna-se importante recorrer à memória dos habitantes do município e ao uso de relatos orais sistematizados por meio da história oral de vida (MEIHY, 2007, p. 37).

Luciano Bernardo de Brito, o Lula, nasceu no povoado do Velame, em Morro do Chapéu, em 13/12/1975 e ainda vive no lugar. Além de atuar como coordenador da Regional de Trânsito (Retran) de Morro do Chapéu ajuda a família a produzir na propriedade de cerca de 30 hectares que o pai possui no povoado. Lula narra qual era o valor que a mamona tinha quando era criança, quando o cultivo da cultura era comum nos sítios e fazendas próximas.

\footnotetext{
Na minha infância, todavia a gente cultivou a mamona. Era uma prática do diaa-dia. Era tipo uma forma única de subsistência mesmo, pelas dificuldades. Não era valorizada. Eu costumava catar mamona com minhas irmãs. Vendia no final do dia, no final da semana, ajudava meu pai a fazer a feira, mas era pouco valorizada. Um quilo de mamona você trocava por três balinhas. Eita que era um sofrimento. Um litro né, meio litro, a medida antiga daqui. Não tinha balança, colocava dois litros, era equivalente a um quilo. (Luciano Bernardo de Brito, 2011, propriedade do entrevistado no Velame)
}

Com a criação do PNPB e a escolha da mamona como uma das culturas que teria a produção incentivada, a localidade do Velame se tornaria a primeira de Morro do Chapéu a experimentar as dinâmicas desenvolvidas localmente a partir do programa federal. Consequentemente, as propriedades rurais locais da agricultura familiar que trabalhavam com a cultura se consolidam na função de produzirem a mamona, agora não mais para a indústria ricinoquímica, mas para a cadeia dos biocombustíveis. 
O mesmo acontece com diversas propriedades rurais da região do Icó, com a diferença de que nesta localidade a cultura da mamona passa a se desenvolver principalmente após o PNPB, como alternativa ao processo de declínio de culturas agrícolas como a do sisal. As vantagens oferecidas pelo programa federal fizeram o cultivo da oleaginosa se espalhar até mesmo por regiões mais úmidas de Morro do Chapéu, como Fedegosos. Além de ser conhecida pela diversidade da produção agrícola, a localidade possui parte considerável do rebanho bovino do município.

Descrever o território-rede dos gêneros alimentícios, representado pelas relações de produção e comercialização, entre outras, das diversas culturas agrícolas existentes em Morro do Chapéu seria uma tarefa muito mais complexa. Mesmo a tentativa de estabelecer o território do PAA no município seria um desafio grandioso. Isso porque, mesmo limitando a rede do programa a algumas culturas agrícolas, haveria de lidar com a extensa espacialização do programa, espalhado em diversas localidades, e com a pouca influência dos fluxos desenvolvidos pela iniciativa pública organizada pela Coopaf.

Além dos três territórios da mamona em Morro do Chapéu citados, a sede do município também pode ser considerada um dos principais "nós" da rede estabelecida pela mamona no município e na região. Isso porque é lá que foi instalada a sede da Coopaf, a principal cooperativa responsável pela execução do PNPB na esfera regional e do PAA na escala local. Além de deter a estrutura operacional para o plantio, acompanhamento técnico, logística de retirada da mamona das roças e distribuição para as usinas esmagadoras, a cooperativa também administrava os recursos financeiros destinados às ações do PNPB na região e concentrava o núcleo local de decisões relacionadas ao programa federal. O mesmo acontecia no caso do PAA.

A Coopaf é fundada em Morro do Chapéu no final de 2005. Com recursos do governo federal, a cooperativa passa a oferecer sementes para o plantio da mamona, dar assistência técnica e organizar os produtores rurais da região no período de comercialização para o fornecimento ao programa do biodiesel. No ano seguinte uma usina de produção de óleo da BrasilEcodiesel, empresa privada parceira do programa, se instala nas proximidades, no município de Iraquara (BA).

As mudanças sócio-espaciais em Morro do Chapéu passam a se dar de maneira mais intensiva após o período de estruturação das atividades da Coopaf. Em 2007, a cooperativa passa a realizar com mais intensidade a organização e a capacitação dos agricultores, o serviço de assistência técnica e a intermediação da compra e distribuição 
da produção. A Coopaf elabora ainda o projeto do PAA para a compra de produtos da agricultura familiar e distribuição às comunidades carentes de Morro do Chapéu.

Um dos principais efeitos da intensificação do uso da mamona para a produção de biodiesel foi o rápido aumento do preço da saca do produto no mercado nacional. Isso ocorreu porque a indústria ricinoquímica que, anteriormente, era o único destino para o óleo de mamona passou a ter como concorrente direto a indústria dos biocombustíveis. Em Morro do Chapéu e em toda a região, o fato da cooperativa ter entrado no mercado representou uma significativa alta no preço do produto. $\mathrm{O}$ valor da saca de 60 quilos de mamona, entre $\mathrm{R} \$ 18$ e $\mathrm{R} \$ 20$ antes do programa do biodiesel, já havia dobrado nos primeiros meses após o lançamento da iniciativa.

Com o incentivo do programa federal, os agricultores passaram a receber da Coopaf gratuitamente as sementes de espécies de mamona adaptadas ao clima semiárido produzidas pela Empresa Brasileira de Pesquisa Agropecuária (Embrapa). Além disso, os agricultores tiveram acesso a novas técnicas de plantio e cultivo da mamona que melhoraram diretamente a produtividade. Técnicos agrícolas da cooperativa passaram a realizar visitas frequentes repassando instruções relacionadas ao preparo do solo para a semeadura, ao espaçamento sugerido entre as "ruas" semeadas, à limpeza do solo e à retirada das espécies concorrentes e das mudas que crescem fora dos pontos de plantio, aos períodos para a realização das "quebras" dos cachos de mamona e técnicas de secagem e armazenagem das sementes.

A assistência técnica fornecida pela cooperativa gratuitamente passa a surtir efeitos positivos em relação à produtividade do cultivo da mamona, um dos principais problemas para o desenvolvimento da cultura no semi-árido.

A gente tenta procurar mais este caminho, porque hoje é melhor trabalhar numa área menor e com mais cuidado do que tentar trabalhar numa área maior e não ter condição total de levar os tratos necessários até o final. Como a gente vê em alguns casos, o produtor faz algum investimento, mas o planejamento não é bem executado e chega na hora " $H$ " falta um recurso para ser aplicado, por exemplo, no controle de plantas invasoras, que é a capina. Faltou o recurso, passou uma semana, passou duas, não fez aquele trato e isso prejudica a produção. Isso pode prejudicar $10 \%, 20 \%$ a produção final. Esse tipo de coisa acontece e causa a baixa produtividade, de 600 quilos, onde a gente poderia chegar talvez a 1.000, 1.200 quilos por hectare. Então, nosso foco é trabalhar mais no aumento de produtividade, que é um processo um pouco complicado, demanda tempo. São etapas que têm que ser concluídas, uma após a outra, sem ultrapassar. Então, temos esse desafio para alcançar. Esta é a tendência. Temos observado que em alguns casos tem se conseguido. Muitos agricultores têm relatos de terem conseguido 1.000 quilos, 1.200 quilos por hectare, apenas aplicando tecnologias simples. Qualquer coisa que seja diferente e que está ali, que resolva aquele problema, com uma simples curva de nível, por exemplo, 
pode resolver, ter um aumento de $20 \%$ de produtividade. (Fabrício Amorim, 2011, residência do entrevistado).

Como a produção de mamona ainda é dependente de certa regularidade na incidência das chuvas na maior parte do município, especialmente nas localidades que não possuem oferta de água no subsolo a um custo razoável para a realização de perfurações, as safras que receberam um volume razoável de precipitação proporcionaram colheitas recordes na região nos últimos anos, favorecidas pelas novas técnicas. Em compensação aquelas lavouras que não recebem o mínimo exigido de chuvas, mesmo com a adaptabilidade das sementes fornecidas ao clima do semi-árido, têm a produtividade radicalmente afetada.

Rosemiro José da Silva (Figura 2.1.7), produtor rural do Icó, lembra da produção obtida na última safra de 2010. "No ano passado a mamona de outubro, foi surpreendente. [...] Se eu estivesse daqui a uma distância de 200 metros, a mamona encobria a pessoa. A gente pra quebrar ${ }^{11}$ mamona precisava ficar puxando galho, quebrando galho" (Rosemiro José da Silva, 2011, propriedade do entrevistado no Icó).

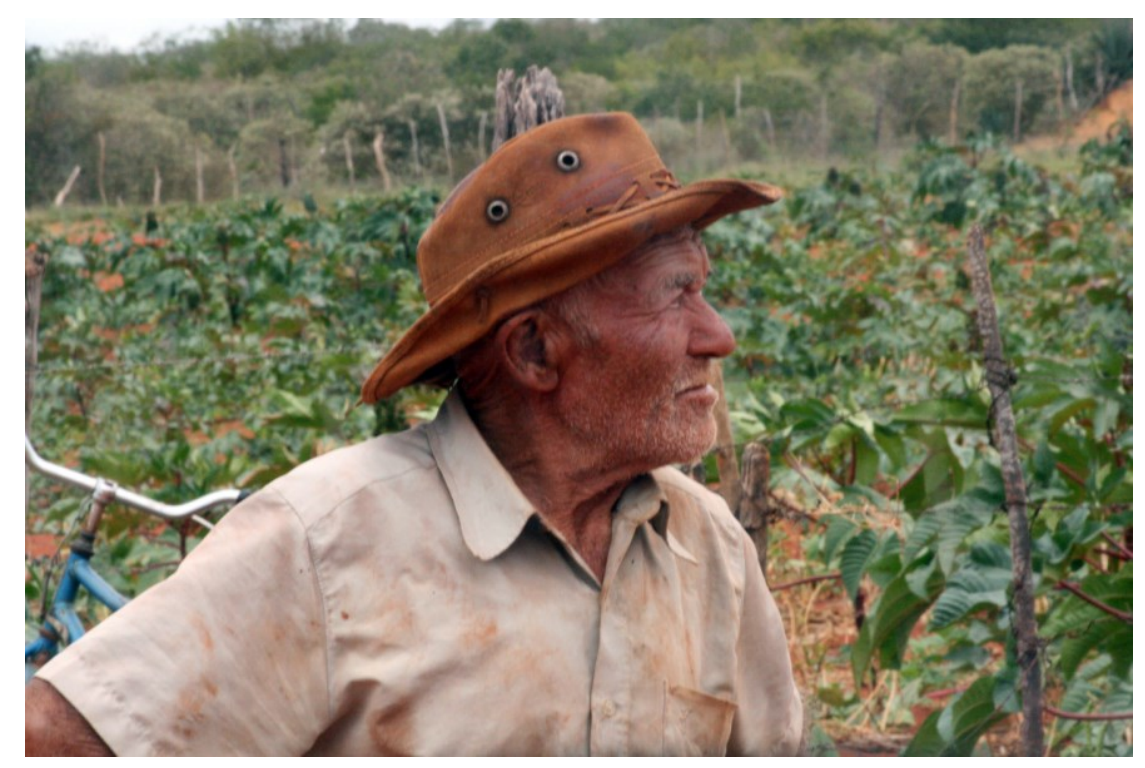

Figura 2.1.7 - Rosemiro José da Silva, do povoado do Icó, em Morro do Chapéu. Ao fundo a plantação de mamona na propriedade do agricultor. Foto: Joana Horta, em 21/02/2012.

Com o programa, o preço da saca da mamona se valoriza, até que em 2009 a Petrobras cria a PBio, investe em usinas próprias e em parceria com outras empresas, instala sua maior usina nordestina na cidade de Candeias (BA) e passa a atuar na cadeia

\footnotetext{
${ }^{11}$ Termo utilizado para designar a colheita da cultura.
} 
do biodiesel. A Coopaf se torna parceira da PBio recebendo recursos financeiros da empresa para prestar serviços de assistência técnica para a cadeia da mamona e realizar a compra e repasse da produção.

Como será visto, o PNPB influenciou a formação territorial de Morro do Chapéu e da microrregião numa medida maior que a considerada tanto por publicações do setor do biocombustível, como é o caso da revista BiodieselBR, quanto por uma publicação ligada aos movimentos sociais. Esta, com base em depoimentos colhidos de agricultores no semi-árido baiano em 2009, sugere que a "entrada da Petrobras no mercado de mamona do Estado [...] resultou, até agora, apenas numa oscilação favorável de preços, pouco alterando a cadeia produtiva da cultura em termos de área plantada ou mesmo quanto às formas de comercialização" (GOMES, 2009, p. 52).

\subsection{Agricultura familiar no município}

Para promover uma análise das dinâmicas sociais produzidas pelo PNPB é importante considerar a situação da agricultura familiar, uma vez que o programa se propõe prioritariamente a beneficiá-la. Para isso, parte-se da seguinte definição para o termo:

\footnotetext{
O ponto de partida é o conceito de agricultura familiar, entendida como aquela em que a família, ao mesmo tempo em que é proprietária dos meios de produção, assume o trabalho no estabelecimento produtivo. É importante insistir que este caráter familiar não é um mero detalhe superficial e descritivo: o fato de uma estrutura produtiva associar família-produção-trabalho tem consequências fundamentais para a forma como ela age econômica e socialmente. No entanto, assim definida, esta categoria é necessariamente genérica, pois a combinação entre propriedade e trabalho assume, no tempo e no espaço, uma grande diversidade de formas sociais. (WANDERLEY, 1996, p. 2)
}

No caso desta pesquisa, é importante considerar que o termo também "é uma construção política, muito mais que um conceito, e que é idealizado pelas políticas públicas como formas de representação, distante da realidade social desses sujeitos que também possuem outras denominações [...] como pequeno agricultor, camponês etc." (FERNANDES, MARQUES, SUZUKI, 2007, p. 11). Por outro lado, compreendida “como forma de organização da produção, seu estatuto é conceitual e, por princípio, universalizável, todavia, desde que capaz de dispensar os conteúdos situacionais e as 
condições de inserções em variadas formações socioeconômicas" (NEVES, 2007, p. 266).

Evidentemente, é preciso considerar, antes de tudo, que o "modelo original" do campesinato brasileiro reflete as particularidades dos processos sociais mais gerais, da própria história da agricultura brasileira, especialmente: o seu quadro colonial, que se perpetuou, como uma herança, após a independência nacional; a dominação econômica, social e política da grande propriedade; a marca da escravidão, e a existência de uma enorme fronteira de terras livres ou passíveis de serem ocupadas pela simples ocupação e posse (WANDERLEY, 1996, p. 8).

É importante ressaltar que estes aspectos fazem parte da formação territorial de Morro do Chapéu e que a divisão do país em sesmarias, "as quais deram origem aos latifúndios atuais", também fizeram surgir um dos "grandes obstáculos ao nosso pleno desenvolvimento econômico, social, político e cultural" (FACÓ, 1983, p. 16) o que impõem sérios limites ao desenvolvimento dos pequenos agricultores.

O monopólio da terra, abrigando em seu seio uma economia monocultora voltada essencialmente para a exportação de alguns produtos, entravou brutalmente o crescimento das forças produtivas. Por mais de três séculos baseou-se no regime do trabalho escravo, que se levantou como uma barreira do trabalho livre. Do trabalho escravo ainda hoje restam marcas evidentes em nossas relações de produção no campo. É o trabalho semi-servil em vastas áreas do interior, particularmente no Nordeste. O monopólio da terra e o trabalho escravo impediram, por sua vez, ou dificultaram muitíssimo o advento da tecnologia moderna (FACÓ, 1983, p. 16).

Pode-se citar como exemplo, a ser explorado mais à frente, que os primeiros tratores de alguns dos territórios estudados e a prática da irrigação só passaram a se dar mais intensamente nos últimos anos em Morro do Chapéu.

Além do debate das diferenças entre o campesinato e a agricultura familiar para definir as condições de existência dos atores-chave do estudo no município é importante se ater às semelhanças com alguns conceitos consagrados "para a compreensão do ator social a que estamos nos referindo" (WANDERLEY, 2003, p. 58) quando se trata da agricultura familiar.

Mesmo sendo uma identidade "atribuída", na maioria dos casos, ela é incorporada pelos próprios agricultores e à diferença de outras denominações impostas de fora [...], ela aponta para qualidades positivamente valorizadas e para o lugar desse tipo de agricultura no próprio processo de desenvolvimento. [...] o agricultor familiar não é um personagem passivo sem resistência diante de forças avassaladoras vindas de fora e de cima do seu universo. Pelo contrário, ele constrói sua própria história nesse emaranhado campo de forças 
que vem a ser a agricultura e o meio rural inseridos em uma sociedade moderna. E o faz recorrendo à sua própria experiência (camponesa) e procurando adaptar-se [...] às novas "provocações" e desafios do desenvolvimento rural. [...] O fio condutor dessa formulação deve ser [...] a já referida capacidade de resistência e de adaptação às transformações mais gerais da sociedade. (WANDERLEY, 2003, p. 58-59)

É interessante ressaltar que, apesar dos entrevistados para esta pesquisa estarem identificados com os aspectos acima citados, alguns demonstravam suas próprias referências construídas do que vem a ser o termo agricultura familiar, que não necessariamente fugiam do contexto abordado. Numa destas construções houve a comparação do termo como se a agricultura familiar fosse um programa público que vinha beneficiando a categoria nos últimos anos.

Obviamente, o agricultor familiar não esgota a variedade de atores que habitam as áreas analisadas. É apenas a categoria que mais interessa a este trabalho. Além disso, mesmo a condição de vida do agricultor familiar pode constituir grande mobilidade, sendo drasticamente alterada de acordo com a situação social. Isso acontece, por exemplo, quando ele deixa de possuir a propriedade ou o controle dos meios de produção.

Numa tentativa de buscar aproximações da categoria do sertanejo à do caipira (DIEGUES, ARRUDA, 2001, p. 50) e do camponês, por exemplo, é possível estabelecer semelhanças da realidade nos povoados em Morro do Chapéu e aquela citada na conclusão de uma das obras de Antonio Candido. A comparação serve mais para determinar a situação de vulnerabilidade a qual o agricultor familiar está exposto, tanto na Bahia quanto em outros Estados.

Para Candido, do "ponto de vista do ajuste ao meio, e correspondente organização da sociabilidade, a vida tradicional", no caso dos caipiras, "apresentava as suas soluções mais características no plano do bairro agrícola, onde sitiantes proprietários ou posseiros - mantinham relativa estabilidade" (CANDIDO, 2010, p. 247).

No entanto, as condições de instabilidade sempre atuavam de modo sensível, por motivos já expostos, criando grande número de miseráveis moradores isolados, ou de agregados vivendo à sombra dos sitiantes prósperos, quando não inteiramente na sua dependência, sem despender esforço produtivo, definindo o tipo clássico do mumbava (CANDIDO, 2010, p. 247, grifo nosso).

Essa situação também se deu na zona rural de Morro do Chapéu. Apesar das diferentes realidades que marcam a vida de cada habitante e dos mais diversos povoados 
do município baiano é possível considerar uma série de semelhanças entre a condição de vida dos trabalhadores da agricultura familiar. Como estratégia para a definição do grupo social em estudo essas semelhanças serão apresentadas a partir da história de vida dos agricultores.

É o caso de José Barbosa de Jesus, ou Zé Capoeira, um dos agricultores mais antigos do grupo do Icó, em Morro do Chapéu, que forneceu mamona para a Coopaf. Ele nasceu no município de Mundo Novo (BA), em 1938, e passou a viver e trabalhar com os avós e a família em Morro do Chapéu quando tinha, aproximadamente, dez anos de idade, após o falecimento da mãe, a convite de um proprietário de terras. A família mudou-se para o Icó quando a área ainda era uma grande fazenda que ainda levava o nome de Joana Castelo Branco, dona da sesmaria que compreendia Morro do Chapéu.

Nos anos que se seguiram à chegada de Zé Capoeira ao Icó, o agricultor trabalhou sucessivamente nas "roças dos outros" (José Barbosa de Jesus, 2011, propriedade do entrevistado) na região. Apenas em 2009, por conta da divisão por herança de uma propriedade de 400 tarefas $^{12}$, na ocasião da morte do sogro, o agricultor pôde trabalhar numa terra própria, registrada no nome da esposa, na qual, atualmente, cultiva a mamona, entre outros gêneros, com a ajuda dos filhos. A disputa judicial encabeçada por José Barbosa contra um dos irmãos da esposa que reivindicava mais terras o fez revelar a situação a qual viviam os familiares que habitavam as terras e que estavam sendo ameaçados. "Como é que eu vou deixar estas mulheres sem nada aqui" (José Barbosa de Jesus, 2011, propriedade do entrevistado), indagou-se.

Amigo de Zé Capoeira, o agricultor Rosemiro José da Silva possui uma propriedade de 22 hectares próximo do Icó e mora no povoado desde 1962. Rosemiro se lembra da propriedade do pai, localizada próxima da sede de Morro do Chapéu e da falta de espaço para que todos os filhos pudessem produzir. Assim Rosemiro, nascido no ano de 1936, logo cedo passou a trabalhar na propriedade de outras pessoas - entre elas Tolentino Oliver Guimarães, que em 1962 se candidataria à prefeitura do município e sairia derrotado (CUNEGUNDES, 1981, p. 22). Apenas em 1959 o agricultor conseguiu comprar o próprio sítio, então, de propriedade de Jubilino Cunegundes (Rosemiro José da Silva, 2011, propriedade do entrevistado no Icó). O agricultor narra o que representou a conquista da propriedade da terra:

\footnotetext{
${ }^{12}$ Aproximadamente 200 hectares.
} 
Quando eu fui trabalhar para os outros era porque não tinha condições de jeito nenhum. Era obrigado. Meu pai tinha um propriedadezinha, ainda hoje tem, os filhos têm, encostadinho o Morro do Chapéu. Não dava para todos os filhos sobreviverem com a propriedadezinha dele porque era pequeninha. Quando eu comprei essa, eu comprei para futurar vir, fazer minha vida aqui, criar minha família aqui e tudo aconteceu como eu pensei. Não arrumei nada de futuro, condição financeira, mas consegui criar meus filhos trabalhando em cima do meu. Se eu morrer, não tenho mais preocupação, pois como eu fui criado, posso deixar para eles se criarem também. Eles ainda têm uma condição melhor do que eu, porque a maior parte da minha infância eu vivi na condição de empregado dos outros. Eles sempre trabalharam na terra deles, trabalham aqui comigo. As filhas mulheres não. Seis casaram graças a Deus. Nenhum dos maridos é agricultor. Trabalham em comércio, emprego público (Rosemiro José da Silva, 2011, propriedade do entrevistado no Icó).

O filho do agricultor trabalha na propriedade junto com o pai, um dos cunhados de Rosemiro e um neto. Em 2011, durante o inverno, a escassez de chuvas se mostrava relevante para a pequena produção das 30 tarefas de mamona que haviam plantado (Figura 2.2.1).

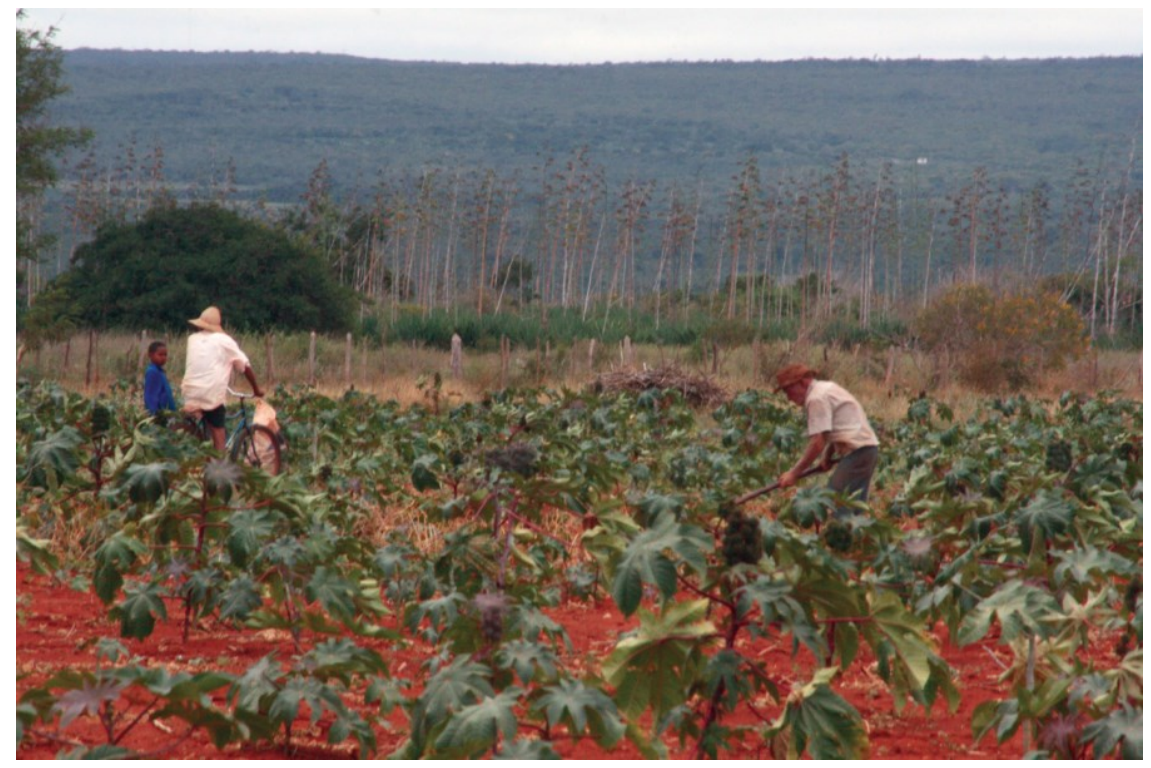

Figura 2.2.1 - Agricultor Rosemiro realiza a "limpeza" da roça de mamona na sua propriedade no Icó, em Morro do Chapéu, com a enxada, enquanto o filho passa ao fundo montado na bicicleta, na manhã de 21/02/2012. A situação da safra observada em 02/07/2011 era pouco menos favorável por conta da maior escassez de chuvas. Ao fundo da imagem, em outra propriedade, uma plantação de sisal, que já foi uma cultura tradicional do povoado, mas que perde cada vez mais espaço para a mamona. Foto: Joana Horta

Como o plantio da mamona é uma das alternativas históricas de trabalho e de renda em Morro do Chapéu e em toda a região de Irecê, especialmente por conta da adaptação da cultura ao clima semi-árido, no momento em que o governo federal, passou a influenciar diretamente a cadeia produtiva, a situação do agricultor também 
sofreu mudanças. Agricultores como Rosemiro e Zé Capoeira passaram a comercializar sucessivas safras com valores mínimos garantidos, ao contrário de quando os preços eram definidos apenas pelo maior comprador da região, um atravessador da cidade de Várzea Nova.

\footnotetext{
Você sabe quanto saía um saco de mamona aqui? R $\$ 10$. O agricultor batia e o atravessador chegava com o depósito: 'Eu pago é tanto'. E você tinha que vender, não tinha opção. Depois que a cooperativa (Coopaf) entrou [na cadeia produtiva da mamona], mudou. Hoje um saco de mamona é R\$ 80, R \$ 90, R\$ 100 que deu aí (José Barbosa de Jesus, 2011, propriedade do entrevistado).
}

Isso mostra que a presença de mais um ator atuando no mercado da mamona representou uma maior disputa pelo produto e influenciou a alta do preço da cultura. Do mesmo modo, a variação no valor da mamona pago ao agricultor estava defasada. Isto é, a maior parte dos ganhos financeiros oriundos da cultura não ficava com o ator da cadeia produtiva que mais dedicava trabalho e que arcava com todos os custos relacionados aos fatores de instabilidade da produção, no caso o trabalhador rural. A ação do ator público serviu, no mínimo, para amenizar a desigualdade de ganhos financeiros da agricultura familiar dentro da cadeia produtiva da mamona.

\subsection{PAA e ampliação da infraestrutura}

Morro do Chapéu obteve por um ano a oportunidade de realizar um projeto vinculado ao PAA. A Coopaf foi a responsável pela execução da atividade em 2008. A cooperativa era remunerada para realizar a compra de diversos produtos da agricultura familiar do município e, utilizando estrutura própria, distribuía sacolas de alimentos, com o apoio de associações comunitárias e entidades filantrópicas, para a população mais carente.

Fedegosos foi um dos povoados que forneceu produtos para o PAA. No caso, o beiju, produzido a partir da farinha de tapioca extraída da mandioca cultivada no local e preparada na casa de farinha do povoado. A experiência do grupo de mulheres que forneceu o produto por dez meses para o programa público foi considerada a mais exitosa do município, tanto por conta dos efeitos promovidos pela iniciativa para as participantes, quanto pela regularidade da quantidade fornecida para a cooperativa. 
O beiju compunha as cestas de alimentos que visavam a complementação alimentar de famílias de comunidades carentes, especialmente, da sede de Morro do Chapéu. Entre os produtos de outras localidades do município doados estavam a farinha de mandioca, milho, o mel, o avoador - petisco de polvilho -, doce de marmelo e carne de bode. Por conta das variações naturais da oferta de alguns produtos ou da própria incapacidade de alguns grupos em oferecer um volume regular à Coopaf, algumas localidades forneceram itens por curtos períodos de tempo, ou em pequenas quantidades, dificultando a análise dos efeitos do programa público na pesquisa. Por isso, o caso do beiju de Fedegosos ganhou destaque.

A garantia do preço mínimo estabelecido pela Companhia Nacional de Abastecimento (Conab) por meio do Programa de Garantia do Preço Mínimo para os Produtos da Agricultura Familiar (PGPAF) possibilitava ao pequeno produtor fornecer o alimento utilizado na cesta doada sem defasagem de preço em relação àquele praticado no restante do país.

A engenheira agrônoma Zene Vieira foi a responsável pelo projeto do PAA da Coopaf em 2008. Zene foi a principal articuladora dos grupos que forneceram para o programa e a principal responsável por mobilizar as pessoas a fim de produzir com freqüência para atender as demandas do programa no município. Após este trabalho a agrônoma se tornou diretora de projetos da cooperativa, deixando a Coopaf alguns meses depois para trabalhar em cooperativas de outras cidades da região.

Zene explica os efeitos da implementação do programa, citando o grupo de mulheres do povoado de Fedegosos que forneceram beiju para o PAA. De acordo com ela, o grupo é um dos que apresentaram a maior evolução entre aqueles que participaram do programa em Morro do Chapéu.

Elas produziam o beiju e ganharam dinheiro com isso. Antes elas produziam muito pouco, em pequena escala, para vender na feira. Levavam oito quilos para a feira e vendiam quatro. $\mathrm{Na}$ outra semana faziam cinco quilos e vendiam cinco. Se tivesse oito, tinham vendido. Não tinham uma garantia de produção. A partir do PAA elas conseguiram se organizar. Todo mês a produção era garantida, 100 e poucos, 90 e poucos quilos cada uma. Através da renda que recebiam conseguiram complementar a renda da família e ampliar os fornos. E elas investiam com o dinheiro da cooperativa. A partir do terceiro, quarto mês, conforme viram que o negócio estava dando resultados em termos financeiros, autoestima, o convívio social, elas começaram a ser exemplo para os filhos, que começaram a trabalhar juntos com as mães, pois viram que era viável. $\mathrm{O}$ marido, o filho mais velho iam cuidar da roça de mandioca e elas beneficiavam. O próprio marido e filho, a filha, que às vezes só estudava e ficava dentro de casa, não ajudava na produção, começaram a ir para o forno, para a casa de farinha também. A gente tem registro de chegar lá e estar todo mundo na casa de farinha ralando a mandioca, dentro das casas delas, nos 
quintais. Cada uma tinha um forno extra, que além da casa de farinha onde elas faziam, elas tinham em casa também. (Zene Vieira, 2011, residência da entrevistada)

O presidente do Sindicato dos Trabalhadores Rurais de Morro do Chapéu (STR$\mathrm{MC}$ ), entidade representativa que possui forte vínculo com a agricultura familiar e que se forjou como um importante aliado da Coopaf no município, o agricultor Fábio Pinto, que sucedeu Roberval Barberino - primeiro vereador eleito pelo PCdoB no município, em 2008 - vive numa fazenda na proximidade dos povoados de Malhada de Areia e do Velame e participou das mudanças ocorridas a partir dos programas após 2007. O agricultor cita um dos exemplos de como os produtores rurais se beneficiaram com a simples "garantia de preço" para o fornecimento de grãos para os programas, no caso dos produtos do PAA.

O preço médio do milho aqui, na época de safra, era de R\$ 10 a R\$12. Hoje, nós estamos numa época de safra, de colheita, e na praça o preço médio do milho está na faixa dos R\$28. E isso porque o programa (PAA) também está adquirindo milho e isso vai competir com as granjas, com os outros compradores. (Fábio Pinto, 2011, STR-MC).

O caso do milho é o mais representativo da situação de mercado a que está exposto o agricultor familiar que aposta nas culturas tradicionais produzidas no sertão (Figura 2.3.1). Este possui menos subsídios públicos do que aquele que passou a ser atendido pelo PNPB, por exemplo. Mesmo dentro do programa do biodiesel há disparidade de apoio público dependendo da cultura produzida. Prova disso é o avanço do plantio de soja no Brasil, uma das commodities mais bem-sucedidas no fornecimento de matéria-prima para a produção do biodiesel brasileiro. Neste sentido, a mamona tem desenvolvido um papel marginal mesmo dentro do Estado baiano. 


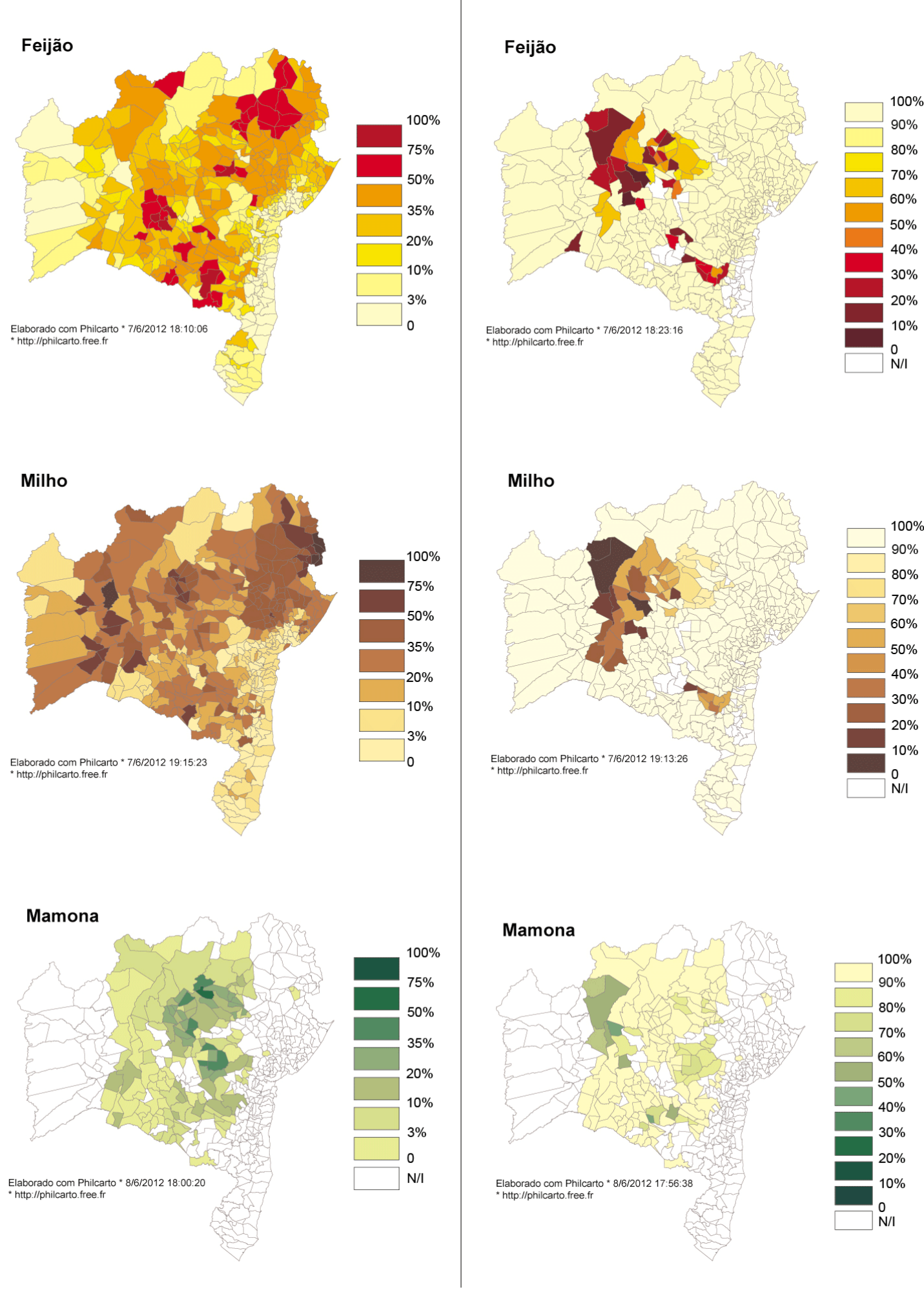

Figura 2.3.1 - Comparação entre a relação entre as áreas plantadas com culturas nos municípios da Bahia e o total de lavouras temporárias em 2010 (coluna da esquerda) e do percentual de áreas colhidas em relação às áreas plantadas com culturas temporárias nos municípios da Bahia em 2010. No caso das legendas da coluna da esquerda, o índice de $100 \%$ refere-se ao total de áreas com culturas temporárias do município ocupadas com a cultura em destaque. Na coluna da direita, o índice de 100\% equivale à colheita total da cultura plantada, enquanto "zero" equivale à perda total da produção. A comparação permite refletir que as perdas com a mamona são menores do que as com outras culturas tradicionais. Fonte: Sidra/IBGE. Elaboração: Vinicius Morende. 
O processo atual de expansão da soja no oeste da Bahia (Figuras 2.3.2, 2.3 .3 e 2.3.4) nos ajuda a entender como um programa público federal afeta "territorialidades pela expansão do plantio de espécies em terras de plantio de gêneros alimentícios [provocando] conseqüências políticas, sociais, econômicas e para o meio ambiente" (FERNANDES, WELCH, GONÇALVES, 2010, p. 807). Mesmo no caso da cadeia da mamona, por meio do PNPB, que não obteve evolução tão expressiva quanto à da soja (Figuras 2.3.5, 2.3.6 e 2.3.7), ou de culturas favorecidas pelo PAA, é possível reconhecer uma série de mudanças promovidas, especialmente, nas esferas econômica e política local.

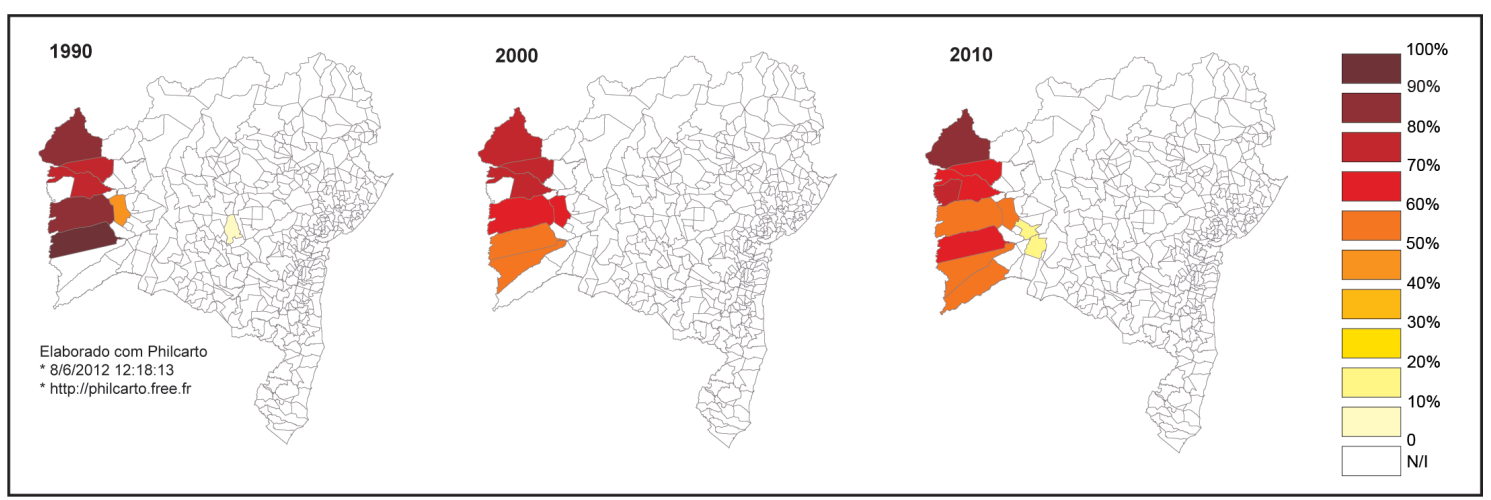

Figura 2.3.2 - Evolução do plantio de soja na Bahia e percentual de áreas plantadas com a cultura em relação ao total de culturas temporárias nos municípios. Na legenda, o índice de $100 \%$ equivale à totalidade de áreas com culturas temporárias plantadas com soja e o "zero" à inexistência de áreas ocupadas com a cultura nos municípios. Fonte: Sidra/IBGE. Elaboração: Vinicius Morende.

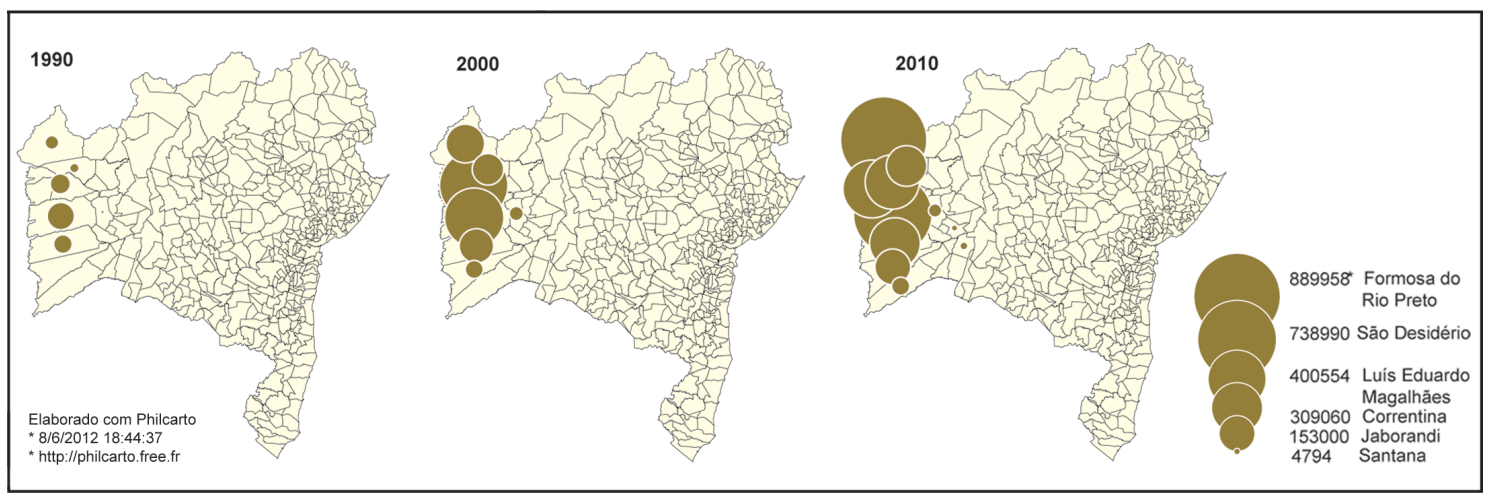

Figura 2.3.3 - Evolução da produção de soja em toneladas por município na Bahia. Fonte: Sidra/IBGE. Elaboração: Vinicius Morende. 


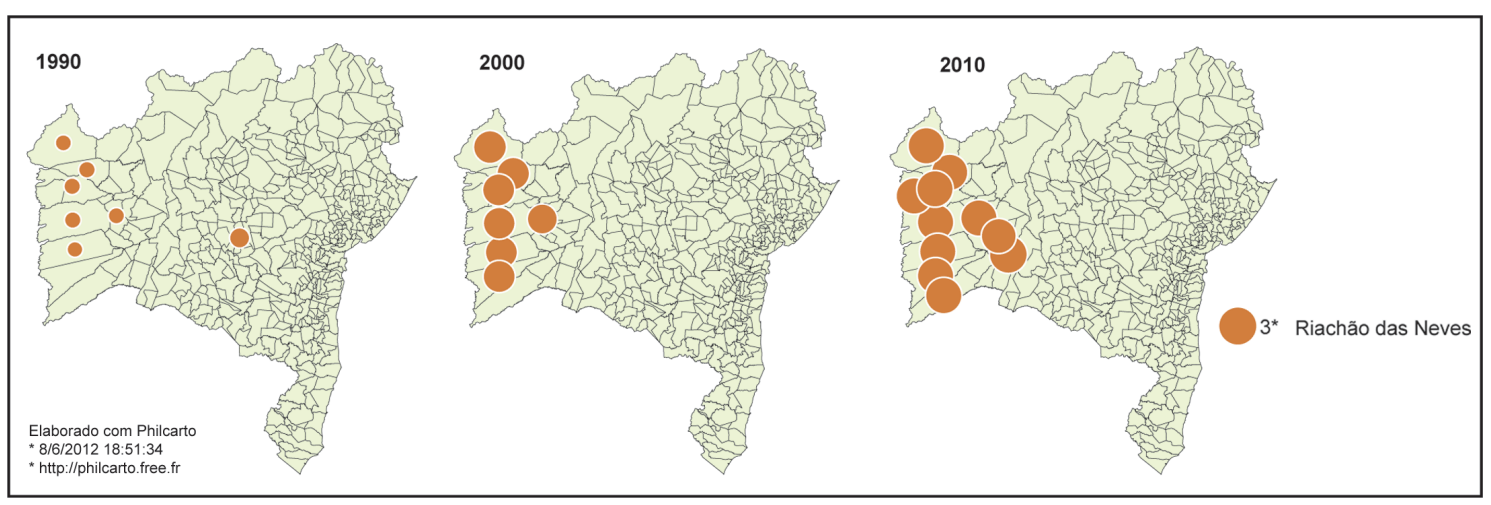

Figura 2.3.4 - Evolução da produtividade da soja nos municípios da Bahia em toneladas por hectare colhido. A produtividade da cultura evoluiu de forma uniforme para todos os municípios produtores, de uma ton./hectare, em 1990, para duas tons./hectare, em 2000, e três tons./hectare, em 2010. Fonte: Sidra/IBGE. Elaboração: Vinicius Morende.

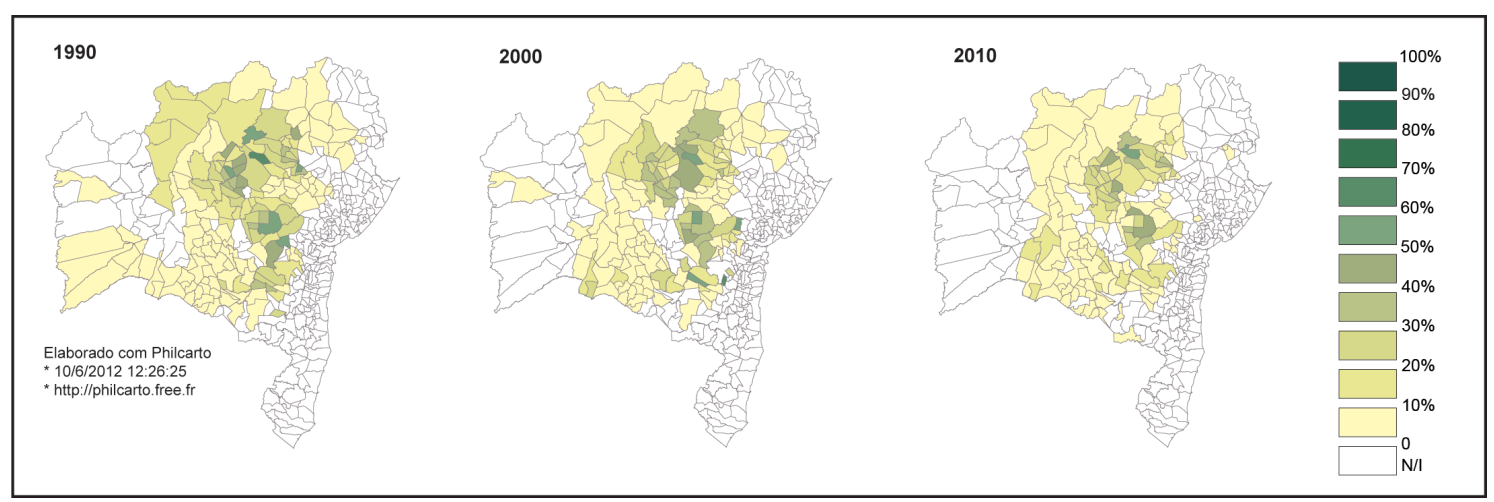

Figura 2.3.5 - Evolução do plantio de mamona na Bahia e percentual de áreas plantadas com a cultura em relação ao total de culturas temporárias nos municípios. Na legenda, o índice de $100 \%$ equivale à totalidade de áreas com culturas temporárias plantadas com mamona e o "zero" à inexistência de áreas ocupadas com a cultura nos municípios. Notar a concentração do plantio nos municípios da Chapada Diamantina, em 2010. Fonte: Sidra/IBGE. Elaboração: Vinicius Morende.

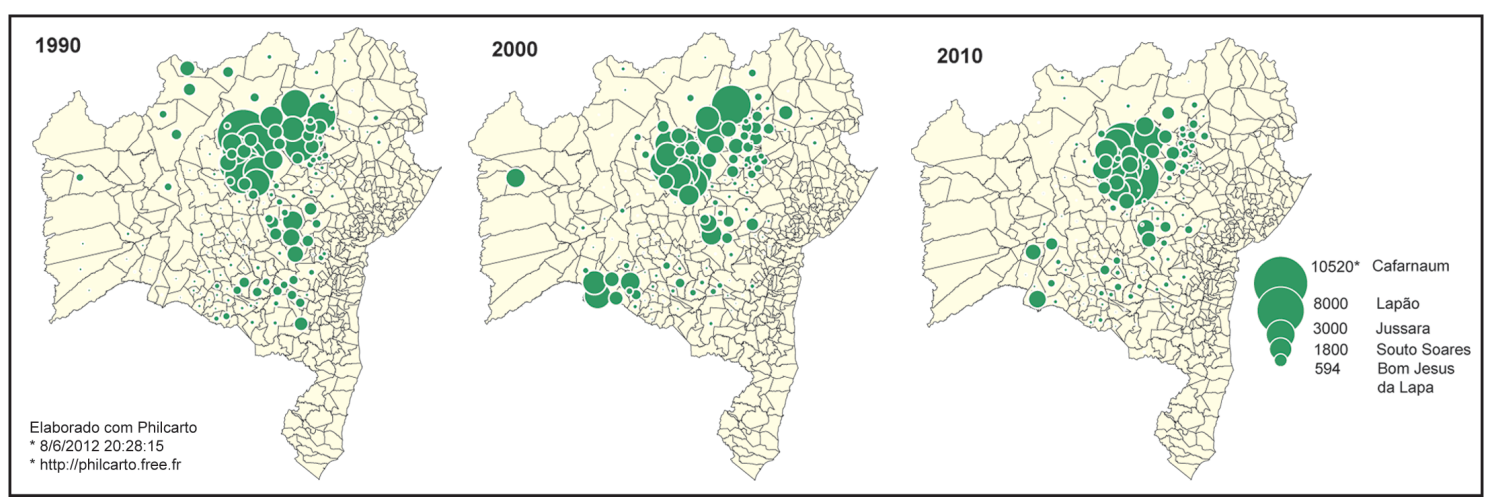

Figura 2.3.6 - Evolução da produção de mamona na Bahia em toneladas por município. Fonte: Sidra/IBGE. Elaboração: Vinicius Morende. 


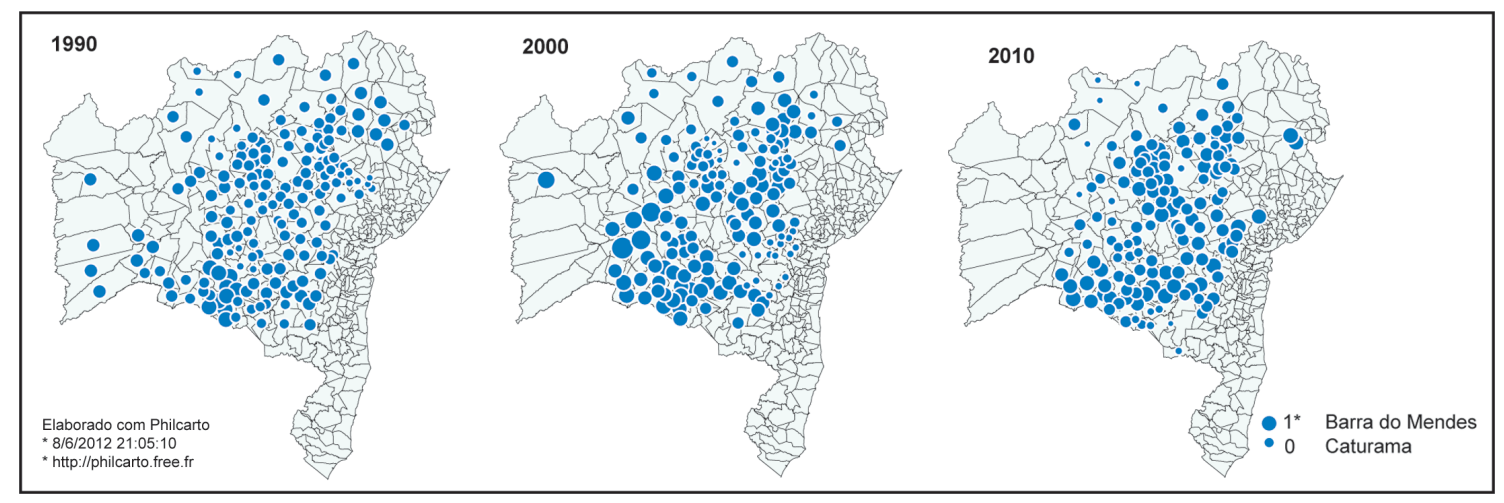

Figura 2.3.7 - Evolução da produtividade da mamona nos municípios da Bahia em toneladas por hectare colhido. A produtividade da cultura evoluiu irregularmente entre os municípios produtores entre 1990 e 2010. Notar que a mamona perdeu espaço para a soja nos municípios do oeste baiano. Fonte: Sidra/IBGE. Elaboração: Vinicius Morende.

Para tanto, é importante reconhecer ambos os programas públicos como frutos da ação de um dos atores responsáveis pela evolução econômica do nordeste, o Estado, e se ater a algumas etapas deste processo. Celso Furtado é um dos especialistas que afirmam que o "atraso político" é a principal razão para o subdesenvolvimento nordestino. "Esse atraso se manifesta basicamente no Nordeste [...] A política representa muito menos para uma região rica do que para uma região como o Nordeste, que depende do governo" (FURTADO, 1998, p. 52).

De acordo com o autor, as principais características da economia nordestina até meados do século XX eram a produção extensiva de gêneros agrícolas voltados para a exportação, a pecuária no sertão e a concentração das elites proprietárias de terras nos centros urbanos da região.

Novas iniciativas que influenciam a formação territorial do país passam a se dar ao longo do século XX e afetar a dinâmica econômica nordestina, a favor da "expansão capitalista do país" (COSTA, 1991, p. 54), concentrados na figura do Estado. Da característica dos capitais investidos "que necessitavam geografizar-se para reproduzirse, resulta como lógica a reestruturação e adequação do território que lhes servirá de suporte, palco e objeto de reprodução" (COSTA, 1991, p. 54-55). O beneficiamento de uma região do país em detrimento de outra permite a adoção da ideia de que as políticas territoriais serão "cada vez mais subestratégias da política econômica maior" e "ocuparão capítulos periféricos dos grandes planos nacionais de desenvolvimento" (COSTA, 1991, p. 55).

O fortalecimento de programas federais de infraestrutura a partir de 2003 pode ser considerado outro marco na análise da história econômica recente da região. Foi 
intenso o volume de investimentos públicos federais que chegaram ao Nordeste no período por meio de programas como Água Para Todos, Luz Para Todos, o Programa de Aceleração do Crescimento, Fome Zero, Bolsa-Família, Territórios da Cidadania, PNPB, entre outros.

Entre as grandes obras de infraestrutura, que demandam grande volume de recursos federais está a transposição do rio São Francisco e a renovação das estradas da região, especialmente na Bahia. Obviamente, os recursos públicos federais são aportados de muitas outras formas, como, por exemplo, financiamentos de bancos públicos de fomento, criação de novas universidades públicas, verba para a área de saúde, educação etc. Relacionando a dependência das economias locais às aposentadorias e aos salários dos servidores municipais fica evidente a importância do poder público, especialmente o federal, para a região.

Ações para o saneamento básico, distribuição de água, da rede de energia elétrica, além dos programas de transferência de renda já existiam antes do período analisado. No entanto, as iniciativas se intensificaram deixando de beneficiar apenas as localidades que interessavam aos grupos políticos tradicionais e conservadores. É neste contexto que surgem o PAA e o PNPB.

Obviamente, as alterações nos padrões de vida identificadas no período mais recente analisado não é mérito apenas do PNPB, ou do PAA, mas da intensificação daquilo que o geógrafo Milton Santos chamou de meio técnico-científicoinformacioanal (SANTOS, M., 2009, p. 238). O Nordeste atravessa um período de desenvolvimento crescente na última década. Basta verificar os elevados índices de elevação do PIB para se certificar que houve um processo relevante de crescimento econômico que, possivelmente, tornou a região ainda mais dependente da lógica do mercado global.

Quanto mais 'tecnicamente' contemporâneos são os objetos, mais eles se subordinam às lógicas globais. Agora, torna-se mais nítida a associação entre objetos modernos e atores hegemônicos. Na realidade, ambos são os responsáveis principais no atual processo de globalização. Ao mesmo tempo em que aumenta a importância dos capitais fixos (estradas, pontes, silos, terra arada etc.) e dos capitais constantes (maquinário, veículos, sementes especializadas, fertilizantes, pesticidas etc.) aumenta também a necessidade de movimento, crescendo o número e a importância dos fluxos, também financeiros, e dando um relevo especial à vida de relações. (SANTOS, M., 2009, p. 240) 
No caso de Morro do Chapéu alguns dos objetos técnicos que provocaram mudanças na formação territorial nestes últimos anos são as estradas estaduais e vicinais recém-reformadas e a expansão da rede de energia elétrica, da rede de saneamento básico e de distribuição de água para mais povoados e comunidades da zona rural. Todas estas atividades vieram ligadas diretamente a projetos vinculados aos governos estadual e federal.

A reforma da BA-052, a "rodovia do Feijão", encurtou drasticamente o tempo de viagem entre Salvador e Morro do Chapéu e do município até o limite da rodovia, à beira do rio São Francisco, em Xique Xique (BA). Antes, as camadas de asfalto que eram utilizadas não resistiam ao peso de caminhões e rapidamente formavam buracos que faziam o viajante reduzir muito a velocidade desde as imediações de Morro do Chapéu até Xique Xique.

A pavimentação do trecho da BA-142 que liga a sede do município à BR-242 (Salvador-Brasília), passando pelas cidades de Wagner, Utinga e Bonito também reduziu a viagem à metade do tempo e tornou o trajeto mais seguro. A ligação com a cidade de Jacobina e ao norte do Estado, por meio da BA-426, também foi renovada, facilitando o acesso ao povoado do Icó. O trecho de transição da BR-122 que liga o município de América Dourada (BA) à BR-242 - que também recebe a nomenclatura de BA-122 -, passando por Cafarnaum (BA), próximo à região da Malhada de Areia também foi recém-restaurado (Figura 2.3.8). No caso do atual programa estadual de reformas de rodovias há o diferencial de que junto à contratação do serviço para a pavimentação das rodovias há contratos de manutenção das rodovias por alguns anos. 

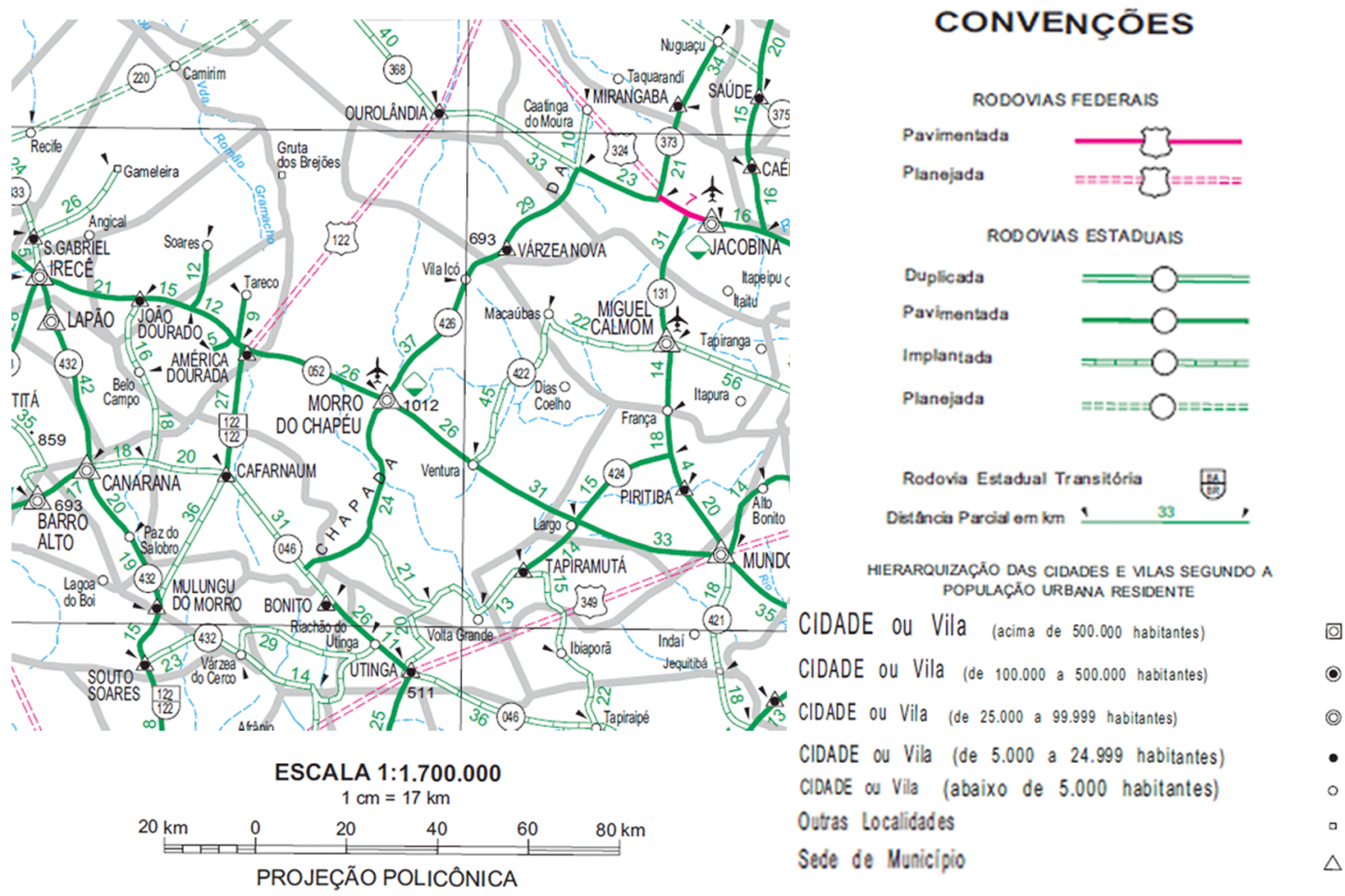

Figura 2.3.8 - Rodovias que atravessam o território de Morro do Chapéu. Fonte: Departamento Nacional de Infra-Estrutura de Transportes (DNIT)

Estas mudanças atenderam ao aumento da circulação de veículos que se deu no Nordeste e em Morro do Chapéu nos últimos anos. Houve o incremento do número de pessoas que possuem o veículo próprio, seja um carro novo ou usado, seja uma moto. A circulação de veículos que funcionam como taxis conduzidos por trabalhadores autônomos também aumentou nos últimos anos. Às sextas-feiras, dia de feira em Morro do Chapéu, cada vez mais carros saem dos povoados logo pela manhã trazendo um número cada vez maior de pessoas e voltam no começo da tarde.

Pode-se dizer que o automóvel faz cada vez mais parte do cotidiano da população da zona rural, ao contrário do período em que era símbolo de status e poder. Um dos mais conhecidos coronéis da história do município, Souza Benta, voltou a Morro do Chapéu após uma viagem, em 1928, a bordo de seu automóvel Ford recémadquirido "com pneus cobertos de couro cru enfrentando tacos, bicos de pedras e buracos" (CUNEGUNDES, 1981, p. 39). Fazia menos de 10 anos que a montadora importara o primeiro modelo da marca para o país e foi a primeira vez que muitas pessoas no caminho e habitantes do município viam um carro.

O agricultor Rosemiro, do Icó, lembra como era difícil conseguir transporte até a sede do município, especialmente, nos momentos de emergência. A viagem a pé pelo 
caminho de pouco mais de 30 quilômetros levava o dia todo. Só no dia seguinte à viagem era possível realizar as tarefas que levavam a pessoa até a cidade. Depois era mais um dia para voltar. Certa vez, com uma das filhas doente, teve que esperar por mais de dois dias até que um caminhão vindo de Várzea Nova lhe desse uma carona para levar a filha ao hospital em Morro do Chapéu. Mesmo assim, a viagem era dura, com areais e atoleiros durante boa parte do trajeto (Rosemiro José da Silva, 2012, residência do entrevistado no Icó).

O processo de intensificação dos objetos técnicos e da complexidade da rede de infra-estrutura durante a formação territorial de Morro do Chapéu permite a verificação de como se deu o "condicionamento dos usos das técnicas, de seus produtos (os objetos técnicos) e, por extensão, das relações sociais” (ANTAS JR, 2005, p. 39), ou daquilo que pode ser compreendido por território como norma. "A cada criação e implementação de objetos técnicos no território, configuram-se demandas por normas de uso e demandas sociais por regulação, e da soma desta resulta a densidade normativa que, de fato, é imensurável” (ANTAS JR, 2005, p. 39).

\begin{abstract}
Este tipo de interação entre espaço geográfico e normas é reproduzido em várias modalidades e escalas distintas. Se tomarmos as infra-estruturas nacionais, como o sistema viário ou o sistema energético, temos que a construção de tais sistemas técnicos parte das leis e, ao mesmo tempo, promove novas demandas por normatização, uma vez que, com a integração territorial, há uma conseqüente aceleração das trocas, exigindo a regulação e padronização, realizadas sobretudo pelo direito comercial e fiscal (ANTAS JR, 2005, p. 69).
\end{abstract}

De acordo com o autor, o mesmo processo acontece numa escala mais detalhada, "embora com um grau de complexidade muito maior, dado serem muitas as variáveis incidentes; apenas uma seleção apropriada e um profundo conhecimento histórico permitem de fato uma análise proficiente" (ANTAS JR, 2005, p. 69).

Considerando que as formas, em essência, funcionalizam processos (SANTOS, 1985, p. 2) é possível verificar “a íntima relação entre formas geográficas e normas: geram, por meio de alguns mecanismos de controle peculiares a cada uma delas, o que se denomina usualmente regulação. A regulação pode ser econômica, social ou política" (ANTAS JR, 2005, p. 55).

Tomando como exemplo o período em que o Brasil se apresentava como um arquipélago de economias, isto é, com divisões sociais e territoriais do trabalho específicas e articuladas com o capitalismo internacional tínhamos nitidamente a formação de regiões delimitadas por atividades definidas, que coincidiam 
com uma regionalização produzida pelas normas morais (ANTAS JR, 2005, p. 67).

Da mesma forma, o avanço da formação territorial se deu quando as normas e ação dos programas públicos federais analisados passaram a se desenvolver a partir das próprias dinâmicas. Essas dinâmicas, possivelmente, também fizeram novas normas morais em escala local, que não serão aqui aprofundadas. Nos próximos capítulos procurou-se verificar como as normas instituídas pelo Estado provocaram efeitos no município, especialmente, no que diz respeito às esferas econômica e a política na escala local e centradas na análise dos dois programas. E tais questões são de suma importância para revelar a participação da figura do Estado na formação territorial de Morro do Chapéu.

A formação do poder político-administrativo formal na escala local de Morro do Chapéu, suas origens, influências e conseqüências, assim como quais os efeitos da ação do PNPB e do PAA para a constituição das relações de poder no local, serão abordados no próximo capítulo. A partir daí será possível desvincular a influência do Estado das dinâmicas que ocorreram a partir de 2007 no município e aprofundar os efeitos sociais e econômicos dos programas analisados para os locais considerados. 


\section{Alterações na estrutura de poder}

Há contradições evidentes nas mudanças provocadas após o início da ação dos programas públicos analisados na esfera política em Morro do Chapéu. Entre elas a de que recursos financeiros da esfera federal chegam a distintos grupos políticos, com atuações local ou regional, em intensidade diferente dependendo do grau de envolvimento, tanto ideológico quanto efetivo, com a administração pública.

Uma análise sobre como o processo de formação da administração pública brasileira rebateu em Morro do Chapéu e no sertão baiano ajuda a entender as dinâmicas ocorridas recentemente dentro da esfera política do município. Do mesmo modo, a análise da formação da estrutura política local e regional auxilia na compreensão de como esta influenciou a construção do poder formal político federal.

Algumas etapas deste processo são representativas para tentar compreender como o poder formal se organizou na escala local e qual a sua importância para a formação territorial de Morro do Chapéu. Uma destas etapas é o coronelismo, incluindo sua decadência a partir da revolução de 1930 no Brasil. Isso porque as reminiscências desta forma política ainda marcam a estrutura do sertão nordestino. Atualmente, o coronelismo pode ser observado em mecanismos de poder como o clientelismo, o paternalismo e outros, especialmente perceptíveis durante os processos eleitorais.

No Brasil como um todo, mas no Nordeste com mais ênfase:

\footnotetext{
Os poderes central e local do Estado historicamente foram apropriados pelas elites e constituem estruturas profundamente antidemocráticas e injustas. $\mathrm{O}$ Estado foi visto como uma extensão do patrimônio privado dos coronéis e seus apadrinhados, e mais recentemente, como refém de interesses do empresariado e do grande capital financeiro. Essa lógica surge de um processo histórico que remonta às capitanias hereditárias e às terras de sesmaria, em que o beneficiário respondia também pelo governo, pelas leis etc. (CHRISTOFOLLI, 2010, p. 234).
}

A relação entre o poder econômico, a ascensão social do coronel e de sua influência política parece ser evidente não só em Morro do Chapéu, mas em toda a Chapada Diamantina. Até o final do século XIX era a pecuária a principal atividade econômica e, consequentemente, a função que promovia os coronéis na região, como já apresentado no capítulo anterior. 
Para exemplificar, vale retomar o caso da boiada negociada no fim do século XIX, por Heliodoro de Paula Ribeiro, do povoado de Cochó do Malheiro, principal "nó" de todas as estradas que se dirigiam às Lavras Diamantinas. O povoado, hoje pertencente ao município de Seabra, às margens da BR-242, naquela época possuía "feiras livres e o movimento de tropas e boiadas era tão grande que poder-se-ia comparar ao de Feira de Santana" (QUEIROZ, 1985, p. 16).

Sucede que o lucro da negociação elaborada pelo filho do proprietário do "futuroso" povoado com o apoio não-consentido do crédito do "Capitãozinho", que "caiu de cama" ao saber das dívidas então contraídas pelo filho para o pagamento dos vaqueiros (QUEIROZ, 1985, p. 16), serviu para que Heliodoro se elegesse como “deputado para a Constituinte”, em 1892 (QUEIROZ, 1985, p. 18). Com a alta no valor do gado, o rapaz fizera fortuna "de improviso" e de sua eleição teria nascido a "desgraça das Lavras Diamantinas" (QUEIROZ, 1985, p. 17).

Heliodoro entrara na política após a queda do Império, fora nomeado intendente na Vila do Campestre (atual município de Seabra) e elegeu-se deputado em oposição ao coronel Felisberto de Andrade Sá - "mineiro rico" e chefe da cidade de Lençóis, "a mais importante e mais rica da região", onde na época "viajava-se mais para a Europa que para Salvador ou Rio de Janeiro" (QUEIROZ, 1985, p. 17). Heliodoro torna-se sócio do Conselheiro Luiz Viana, que se encontrava na governança do Estado.

Das primeiras brigas com Felisberto Sá resultam sete assassinatos em diversas localidades da região num curto período (QUEIROZ, 1985, p. 23) e outros tantos se seguem nos meses seguintes até que Heliodoro e o coronel Clementino de Matos, seu aliado, são julgados e absolvidos. Mesmo durante o período de "relativa tranqüilidade" que se seguem nas Lavras Diamantinas, entre 1895 e 1912 (QUEIROZ, 1985, p. 27), diversos crimes continuaram acontecendo sem que quaisquer inquéritos fossem realizados.

A vida do povo era cheia de sobressaltos. Apenas em Morro do Chapéu reinava a paz e havia ordem. Mas em Ventura, por exemplo, por causa do elemento adventício, ávido de riqueza fácil, composto de toda classe de indivíduos, o morticínio durante três anos foi horrível. Quase todo dia matava-se uma pessoa (QUEIROZ, 1985, p. 27).

De acordo com o autor, desta realidade do Ventura "surgiu" Vitor de Matos, integrante de uma das principais famílias da região, assassinado por afrontar a honra de um subchefe do grupo que comandava o município de Lençóis. Após o crime, o irmão 
de Vitor, Horácio de Matos, que se tornaria o coronel da região que exerceu influência na maior escala, exige a "punição judicial", "ao menos aos criminosos" (QUEIROZ, 1985, p. 34). Horácio de Matos havia iniciado a "carreira na Guarda Nacional e na política em Morro do Chapéu" e era "amigo e correligionário" (SAMPAIO, 2005, p. 93) de um dos principais coronéis deste município, Francisco Dias Coelho.

“Ante tamanho menosprezo" (QUEIROZ, 1985, p. 34) das autoridades, Horácio de Matos inicia uma batalha contra coronéis inimigos que tinham apoio do Governo do Estado. Um deles, Manoel Fabrício, “de cócoras, em cima de uma cadeira ou mesmo da mesa de jantar, ditava as leis que haviam de ser executadas em todo o município de Campestre" (QUEIROZ, 1985, p. 35).

\footnotetext{
Ao nosso ver, o poder no sertão estava literalmente dividido entre as oligarquias locais, quase sempre representadas por um coronel, ou uma facção política dominante, na maioria das vezes ditando normas e impondo de forma austera seu domínio, não rara vezes, arbitrariamente (BANDEIRA, 1997, p. $55)$.
}

Horácio de Matos e o coronel Militão Rodrigues Coelho, de Barra do Mendes, dão início a uma guerra na região denominada Chapada Velha que duraria alguns meses. O início do conflito favoreceu Horácio, já que o apoio do governo do Estado ao coronel Militão não foi atendido. Isso porque era grande a oposição política ao governo do "Doutor Seabra", que "desde 1912 dirigia a política acobertando todas as mazelas político-administrativas" (QUEIROZ, 1985, p. 45).

O eco da revolução repercutia em todos os ângulos do sertão, mas nas Lavras Diamantinas a ressonância foi maior que em todos os outros lugares [...]. Isso porque o povo estava farto de sofrer. $\mathrm{O}$ jogo que o dominava provinha ainda dos tempos da monarquia. (QUEIROZ, 1985, p. 45)

O principal conflito desta guerra foi aquele que ficou conhecido como o cerco a Barra do Mendes, no qual a cidade permaneceu sitiada por mais de seis meses até a rendição do coronel Militão. No quinto mês de combate Horácio de Matos recebera o apoio formal do Governo Seabra, que passa a financiar a "Reação Sertaneja" (QUEIROZ, 1985, p. 53), já que o "governo já não tinha forças para abafar os conflitos que surgiam" (QUEIROZ, 1985, p. 51). Nesta época, o poder de Horácio se estendia por uma grande região do sertão baiano, se limitando, ao norte, com Morro do Chapéu.

A intervenção do presidente da República, Artur Bernardes, na guerra sertaneja e o estabelecimento do armistício acontece após Horácio de Matos tomar Lençóis, até 
então em poder da família Sá. Horácio recebe a representação oficial de onze municípios da região, com a "denominação de zona Centro-Oeste, com direito a eleger por essa zona dois Deputados Estaduais e um Senador" (QUEIROZ, 1985, p. 56). Em 1921, Horácio elege-se senador.

Os coronéis de Morro do Chapéu até o início do século XX também eram, em sua maioria, grandes pecuaristas. As dinâmicas da formação da estrutura política de Morro do Chapéu são intensas, principalmente, durante o auge do coronelismo. Para dar início à análise deste processo no local é importante considerar o trabalho de Jubilino Cunegundes, considerado "proprietário e fazendeiro", "sertanejo baiano" (CUNEGUNDES, 1981, p. 41) pelo jornal centenário do Morro do Chapéu, Correio do Sertão, em edição de janeiro de 1947 - na ocasião da indicação de Cunegundes para integrar a "chapa estadual para Deputado" pelo Partido Social Democrático (PSD). De acordo com o autor "a vida político-administrativa" de Morro do Chapéu teve "vinte e seis administradores-Intendentes e Prefeitos" entre 1889 e 1974 (CUNEGUNDES, 1981, p. 22).

Cunegundes também apresenta o "quadro demonstrativo de juízes de direito que exerceram a magistratura" (1981, p. 22-23) na comarca de Morro do Chapéu a partir de 1915. É importante ressaltar a proximidade da sequência com a qual o autor relaciona as autoridades de poderes aparentemente distintos em sua obra. Vale ressaltar que a comarca "é a região que referencia a organização da divisão do trabalho jurídico para o exercício cotidiano da hegemonia soberana na formação socioespacial brasileira" (ANTAS JR, 2005, p. 26). Isto é, "quanto maior o número de comarcas, mais o território do Estado é normado para o exercício da hegemonia soberana" (ANTAS JR, 2005, p. 27). A análise do contexto da criação da comarca da região de Morro do Chapéu, mais a frente, vai facilitar a compreensão da relação entre os poderes formais no sertão baiano.

Em relação aos intendentes do município, aqueles que ficaram conhecidos como os mais influentes são os coronéis Francisco Dias Coelho e Antônio de Souza Benta, que atuaram juntos no poder efetivo e na política de Morro do Chapéu. De acordo com Cunegundes (1981, p. 22), ambos se sucederam no comando da intendência, respectivamente, de 1914 a 1919 e de 1919 a 1920. No entanto, a influência de ambos faz compreender que o período no qual controlaram a vida social e ditaram as regras no município se estendeu além daqueles anos. Para Claudionor de Oliveira Queiroz - neto de um chefe político do Morro do Chapéu e primo de Horácio de Matos -, por exemplo, 
Antonio da Benta, denominação herdada da mãe - a "Velha Benta" (QUEIROZ, 1985, p. 30) -, era um "chefe político dos melhores que dirigiu Morro do Chapéu até 1945" (QUEIROZ, 1985, p. 30), pouco antes da morte do coronel.

Francisco Dias Coelho, "politicamente auxiliava seu padrinho e pai adotivo, o Major Pedro Celestino Barbosa, antigo chefe político local e boticário" (CUNEGUNDES, 1981, p. 25). José Barbosa de Jesus, um dos agricultores entrevistados na região do Icó, reconhecido pelos amigos como conhecedor da história do lugar, afirmou que a família a qual pertencia Dias Coelho era a mesma dos descendentes dos donos da sesmaria que abrangia o município (José Barbosa de Jesus, 2011, propriedade do entrevistado). A influência social de "Seu Chico", como era conhecido, se dá, principalmente, por conta das ocupações que desempenhava:

\footnotetext{
Abrindo-se vaga do Cartório de Tabelião de Notas, foi Seu Chico nomeado tabelião interino. E como esse cargo, naqueles bons tempos, era o pivô da política, porque era nesses cartórios onde se faziam as eleições a bicório, isto é, a bico de pena, os conhecimentos de Seu Chico foram aumentando, como também aumentava seu prestígio pessoal (QUEIROZ, 1985, p. 9).
}

Dias Coelho assume o poder efetivo de Morro do Chapéu após as eleições de 1903, quando seus aliados são eleitos para a Intendência e o Conselho Municipal, e só deixa o controle da cidade após a morte. Ainda durante o Império fora nomeado alferes da Guarda Nacional "quando também acumulava o cargo de oficial do Cartório de Registro de Hipotecas" (LOPES, 2006, p. 39-40). Foi um dos primeiros negros da Bahia a receber a patente de coronel comandante, após organizar a Brigada 73 da Guarda Nacional. A instituição de ordem militar agrupava no local os tenentes-coronéis, capitães "e muitos outros patenteados para comprar a patente e a farda" (CUNEGUNDES, 1981, p. 96). Mesmo após a extinção da guarda:

as patentes continuaram dadas e distribuídas pelo povo, obedecendo, porém o critério de merecimento e a posição social do patenteado. A patente, no interior, é uma forma de homenagear o cidadão sem festas e músicas e mais das vezes um pretexto para obter favores... (CUNEGUNDES, 1981, p. 96).

Por outro lado a incorporação do elemento repressivo nas figuras do coronel e de seus comandados, materializada nas suas ações, reforçavam o papel de autoridades desempenhado. "Todos nós sabemos o que representava uma patente naqueles tempos. A figura do coronel num povoado, numa vila ou até mesmo numa cidade, era a própria lei incorporada numa só pessoa" (BANDEIRA, 1997, p. 55). 
"Capitalista, grande fazendeiro, alto comprador de carbonatos e diamantes para a firma Levy, de Paris" (CUNEGUNDES, 1981, p. 25), Dias Coelho passa a integrar o grupo de emergentes "que dominavam o comércio de diamantes e carbonatos" (SAMPAIO, 2009, p. 95) e que supera o grupo político dos pecuaristas no poder de Morro do Chapéu. Entre outros fatores, a decadência desta atividade era influenciada pela questão climática e pelas secas que assolaram a região, em especial, entre 1898 e 1900.

A intensificação da exploração de minerais nas serras próximas à sede de Morro do Chapéu e, em especial, no distrito do Ventura (Figura 3.1) alteraram drasticamente a estrutura política local, além das formas geográficas permanentemente afetadas pelas técnicas de exploração. "Lá pelos anos de 1905 a 1911, foi o Ventura o local mais próspero do interior do Estado, dado às riquezas do seu símbolo, de onde se extraiu a maior quantidade de excelentes carbonados [sic], nos garimpos" (QUEIROZ, 1985, p. $10)$.

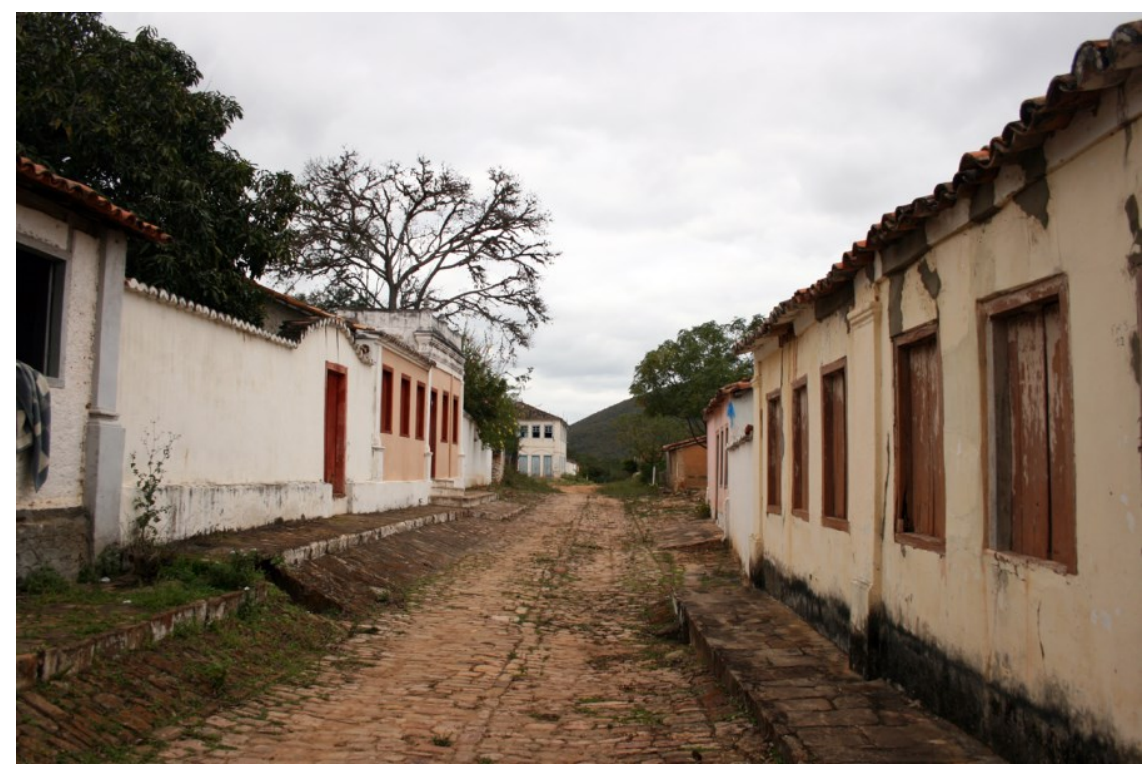

Figura 3.1 - Uma das ruas principais da vila do Ventura, que possuía centenas de casas e milhares de habitantes e visitantes. A vila entrou em declínio com o aumento dos custos de exploração e a queda nos preços das pedras preciosas. Isso fez a vila entrar em forte decadência econômica até ser, praticamente, extinta. Foto: Sthel Braga, em 07/07/2008.

O grupo de Dias Coelho detinha a propriedade dos garimpos, o apoio dos capangueiros - ou pedristas que compravam "o diamante ou carbonato por preços irrisórios, fazendo lucros fabulosos na revenda aos compradores" (CUNEGUNDES, 1981, p. 89) -, consequentemente, o apoio dos garimpeiros e o controle sobre a 
principal função econômica da Chapada Diamantina. As pedras eram vendidas "aos donos das casas comerciais de compra e venda de carbonatos e diamantes, e por fim, estes comercializavam com as empresas européias que exportavam para a Europa" (SAMPAIO, 2009, p. 93). Em Morro do Chapéu, estas casas comerciais pertenciam ao grupo de Dias Coelho, que era o maior "comerciante de pedras da Bahia" (SAMPAIO, 2009, p. 93). A casa comercial mais expressiva do município que fazia o comércio das pedras era a "Coelho \& Nery" (SAMPAIO, 2009, p. 93), cujo nome faz menção aos sobrenomes do coronel e de seu cunhado, que também foi intendente do município.

Aqui se faz relevante considerar aquilo que Milton Santos revelou como um dos elementos do espaço, as firmas ${ }^{13}$ (SANTOS, 1985, p. 6), para a lógica com a qual estavam constituídas as estruturas econômica e política de Morro do Chapéu. De acordo com o arranjo destes elementos, "delineia-se uma demanda pela produção de normas que regulem as relações entre eles" (ANTAS JR, 2005, p. 68). É possível afirmar que a atividade mineradora no município era diretamente controlada, principalmente, pela firma do coronel e que era este quem estabelecia as normas com as quais a sociedade local em geral era regida. Isto era estabelecido de acordo com os interesses de outra firma, no caso, a francesa, para onde a maior parte do minério era destinada e a qual interessava o desenvolvimento da atividade em Morro do Chapéu.

Prova disso era a relação de dependência que o coronel estabelecia com os trabalhadores, que derramavam "suor e às vezes sangue, com o esmagamento de algum membro na remoção da pedreira" (CUNEGUNDES, 1981, p. 89) no garimpo. Dias Coelho teria se forjado na posição econômica referida fornecendo alimentação e utensílios necessários aos garimpeiros em troca da "exclusividade na compra das pedras" (SAMPAIO, 2009, p. 93), o que lhe garantia a negociação direta com os trabalhadores. Ao garimpeiro, "sempre um ignorante do preço do produto", "era indiferente o valor da mercadoria" (CUNEGUNDES, 1981, p. 89).

Vale ressaltar que mesmo tendo o arraial do Ventura e o distrito do Brejinho "uma pujança econômica maior que a própria sede" (SAMPAIO, 2009, p. 92), era no distrito sede que se localizava "o centro das decisões do município" (SAMPAIO, 2009, p. 92). "Todos os líderes municipais mantinham residência e casas comerciais na cidade" (SAMPAIO, 2009, p. 92).

\footnotetext{
${ }^{13}$ Além das firmas, são elementos do espaço: os homens, as instituições, o chamado meio ecológico e as infra-estruturas (SANTOS, 1985, p. 6).
} 
Além de assumir posições políticas de maior destaque, alterando, principalmente, a estrutura política local, a ascensão do grupo emergente também produziu efeitos nas escalas de decisão estadual e federal, além de mudanças na estrutura fundiária e na propriedade das terras em Morro do Chapéu. A sucessão de secas teria contribuído com o declínio quase definitivo da pecuária. Somada aos endividamentos e à fragmentação das propriedades por heranças, a situação fez elevar a oferta de terras disponíveis.

As terras no "entorno de Morro do Chapéu e nos distritos mais propícios à pecuária" (SAMPAIO, 2009, p. 95), foram adquiridas pelos comerciantes de pedras. As propriedades mais distantes da sede tinham pouca viabilidade econômica, por conta da dificuldade de acesso para o escoamento da produção. Estas áreas "continuaram pertencendo às antigas lideranças, estes, portanto, ficaram isolados política, econômica e quiçá geograficamente do centro de decisões" (SAMPAIO, 2009, p. 96).

Para os coronéis emergentes a compra de terras era mais uma mostra de poder do que uma vantagem econômica. Isso porque, mesmo sem o lucro anterior obtido com a pecuária, "eram reconhecidos como ricos, aqueles homens que possuíam uma grande quantidade de animais, evidentemente, que os rebanhos exigiam maiores quantidades de terras e de agregados" (SAMPAIO, 2009, p. 94).

Após a morte de Dias Coelho, Souza Benta assume a chefia política do município, "posto reservado ao coronéis" (CUNEGUNDES, 1981, p. 40), enquanto outros representantes se alternavam na "direção política". De acordo com Jubilino Cunegundes, Benta também era capitalista, comprador de carbonatos e diamantes:

\begin{abstract}
dispondo de crédito largo, tinha possibilidade, como grande proprietário e criador, de ajudar a muita gente, em benefício da terra, mantendo grande número de garimpeiros nas serras do Martim Afonso e outros garimpos, não somente no intuito de comprar o metal por eles pegado nas catas; mas também para que tivesse o material humano agrupado, para, no caso de necessidade, a defesa estar assegurada com rapidez. O Município pregava a paz, vivia em paz, mas sempre preparado para a luta e por isto era respeitado à distância. Não se verificou neles as cenas de saque e cebaça praticados em outros Municípios baianos, pela jagunçada acobertada e orientada por vários chefetes. Antonio Benta não era chefe de jagunços ${ }^{14}$. Jamais invadiu ou mandou invadir localidade vizinha. Mantinha homens em armas para sua defesa, garantia de vida e de bens de seus amigos e manter a paz $^{15}$ e a ordem e o respeito no Município (CUNEGUNDES, 1981, p. 37, grifo nosso)
\end{abstract}

\footnotetext{
${ }^{14}$ A afirmação de Jubilino Cunegundes é expressa a fim de contradizer o historiador Américo Chagas que classificou Souza Benta como "poderoso chefe de jagunços" (CHAGAS, 1996, p. 10).

${ }^{15}$ Obviamente "a paz" a que Cunegundes refere-se é a paz armada e os principais beneficiados pela ordem estabelecida em relação aos coronéis das áreas vizinhas eram os próprios coronéis e seus
} 
Obviamente, Souza Benta, que, ao lado do antecessor Dias Coelho, esteve no controle de Morro do Chapéu no período de maior agitação política da região, detinha o poder de decisão e sobrepunha sua vontade às decisões de esferas políticas superiores. Para Cunegundes, Souza Benta "dispensava absoluto respeito às autoridades e acatava suas decisões, embora, por trás da porta, quando havia interesse armasse o esquema para neutralizar seus efeitos" (CUNEGUNDES, 1981, p. 37). Como no caso em que organizou um grupo que resgatou José Ribeiro, compadre do coronel que "quando moço, serviu de Secretário de José Volta Grande, cangaceiro” da vizinha Mundo Novo (CUNEGUNDES, 1981, p. 37). José Volta Grande fora processado e caçado pela "polícia", e José Ribeiro fugiu se mantendo sob guarda do coronel Souza Benta.

quando apareceu uma escolta ainda de Mundo Novo e o levou preso. Benta na sua calma habitual, aparentemente, não tomou conhecimento, mas, por detrás da porta preparou os meninos bem armados e municiados, mandou arranjar umas caretas e distante desta Cidade alguns quilômetros, no Lagedo da Farinha os caretas assaltaram a escolta $[. .$.$] arrebataram o preso e o trouxeram à noite$ para a Cidade, onde ele permaneceu e morreu de velho (CUNEGUNDES, 1981, p. 38).

Os conflitos entre os coronéis por influência política se acentuaram na década de 1920 na região e novas disputas por representação territorial passam a se intensificar em Morro do Chapéu. Aparentemente, a primeira perda de área do território da freguesia parece ter ocorrido em 1890, ano em que uma grande seca "flagelou quase todo o nordeste do Brasil e para as matas de Mundo Novo, grande quantidade de emigrantes afluiu" (QUEIROZ, 1985, p. 12). Neste mesmo ano é que o "território" de Mundo Novo é desmembrado de Morro do Chapéu e anexado à "Freguesia de Monte Alegre - hoje Mairí” (CUNEGUNDES, 1981, p. 23).

Na ocasião, em contrapartida, Francisco Dias Coelho teria "requisitado a quantia de dois contos, setecentos e oitenta e oito mil e setenta reis, metade dos trabalhos da linha divisória entre este e o Município de Mundo Novo" (CUNEGUNDES, 1981, p. 24) ao Conselho e à Intendência do vizinho. O objetivo da modificação teria sido para "facilitar a administração", mas Cunegundes refere-se ao fato como o início do processo de mutilação do território de Morro do Chapéu (CUNEGUNDES, 1981, p. 23).

Acende-se o pavio de um conflito entre o grupo político do coronel Souza Benta e da família Dourado, grupo de antigos correligionários que já havia se insinuado como 
oposição ao coronel desde o movimento emancipatório do distrito do Ventura - surgido em meados da década de 1910 -, que despontou após a demissão do Coletor Federal, oposicionista ao coronel Dias Coelho, mas que fora contido (CUNEGUNDES, 1981, p. 27-28). Ficou o Ventura, até hoje distrito do município e, na época, o distrito mais recente de Morro do Chapéu, mas a disputa resulta na emancipação daquele que era o distrito mais antigo e um dos mais afastados da sede da cidade, o de Wagner.

A mesma lei que desmembra o distrito de Wagner ${ }^{16}$, em contrapartida, eleva a cidade de Morro do Chapéu ao status de comarca, cuja área de influência da instituição do poder judiciário instalada ia muito além das fronteiras do município, até a Chapada Velha. É importante considerar a influência que a elite econômica e política do município passou a exercer na esfera jurídica formal após a criação da comarca.

\begin{abstract}
Desse modo, temos que todos os agentes participantes da produção do espaço geográfico, justamente nessa condição, alimentam o sistema jurídico, cuja função é regular os usos do território. Segundo essa linha de raciocínio, constata-se que aqueles com maior capacidade de produzir território, segundo interesses gerais ou específicos (agentes hegemônicos), produzem regras com vistas a facilitar suas ações (ANTAS JR, 2005, p. 75).
\end{abstract}

A disputa entre Souza Benta e a família Dourado se acentua até que, talvez, o maior conflito armado da história de Morro do Chapéu começa a ser ensaiado. A disputa era o anúncio da criação do município de Irecê. De acordo com Jubilino Cunegundes, a família Dourada era muito numerosa e proprietária da quase totalidade das terras e dos votos dos distritos de Caraíbas e América Dourada. A luta tem o ápice após as eleições para prefeito em 1923, quando o candidato de Souza Benta vence.

Mas acontece que naqueles tempos de eleição a bico de pena seria vitorioso o
candidato que tivesse o apoio do Governo. E assim aconteceu. O Senado,
obedecendo ordens do Governador, reconheceu válida a simulada eleição do
candidato dos Dourados: o Professor Faustiniano Lopes Ribeiro, desprezando o
voto contrário e contundente do Senador Wenceslau Guimarães
(CUNEGUNDES, 1981, p. 30).

As hostilidades entre correligionários de ambos os grupos políticos se acentuam em Morro do Chapéu e um dos coronéis da família Dourado "no propósito de prestigiar os parentes e lhes garantir posições políticas, aproveitou-se da posição de Comandante da Polícia Militar do Estado, prestigiado pelo então Governador Góes Calmon” e “enviou um contingente policial para este Município" (CUNEGUNDES, 1981, p. 30). O

\footnotetext{
${ }^{16}$ Lei no 1.119 de 21 de agosto de 1915 (CUNEGUNDES, 1981, p. 26-27).
} 
coronel das Lavras Diamantinas, Horácio de Matos, toma conhecimento do acontecido na presença do governador e o persuade violentamente a declinar da iniciativa (QUEIROZ, 1985, p. 64).

O dever de defender os correligionários de Morro do Chapéu expõe o tratamento dos coronéis com as autoridades das demais escalas de poder. No caso específico da Chapada Diamantina os coronéis pareciam desejar "distância e paralelismo do poder com o Estado" (LOPES, 2006, p. 30). O próprio Dias Coelho é citado entre aqueles que "tratavam qualquer governador de Estado como um cidadão igual a eles, não como seu chefe" (LOPES, 2006, p. 31).

Após se silenciar ante os telegramas de ajuda enviados pelo grupo de Souza Benta, o governo do Estado retrocede na decisão, muda o comando do contingente policial enviado a Morro do Chapéu - que já havia cometido "diversas arbitrariedades" (CUNEGUNDES, 1981, p. 30) - e cria o município de Irecê, desmembrando-o de Morro do Chapéu, "entregando aos Dourados as posições políticas, onde realmente predominava o prestígio político daquela família" (CUNEGUNDES, 1981, p. 31). A decisão é tomada a tempo de evitar o eminente choque armado entre as forças armadas a serviço do coronel Souza Benta, dispostas nas áreas de garimpos, nas serras do município, e as forças policiais.

No entanto, a hostilidade de Horácio de Matos com o governador no caso provocaria uma verdadeira guerra na cidade de Lençóis. O governador Goés Calmon demite todas as autoridades oriundas da cidade das Lavras Diamantinas e envia um contingente policial para garantir a posse dos "inimigos mais rancorosos" (QUEIROZ, 1985, p. 68) do coronel. Os jagunços vencem a batalha contra o Estado e Horácio de Matos retoma as posições políticas anteriormente citadas.

Em meio a estas lutas em Lençóis, Horácio de Matos cria uma espécie de guarda “com o fim de policiar a cidade" (QUEIROZ, 1985, p. 85) e um relato ligado a este caso ajuda a avaliar o valor que a mamona e derivados do produto possuíam na região desde aquela época.

Dessa guarda fazia parte um parente de Horácio, o José de Queiroz. Este moço, abusando do parentesco e da confiança que lhe fora depositada, arrombou a casa do árabe Neije Abdon Said, inimigo de Horácio, e dele roubou dezoito latas de azeite de mamona, no valor de quarenta a cinqüenta réis cada. Levado o fato ao conhecimento do Horácio, este mandou executar sumariamente o ladrão (QUEIROZ, 1985, p. 85). 
Um sobrinho do coronel consegue reverter a sentença. O caso acaba com o próprio Horácio de Matos dando "72 bolos de palmatória no prisioneiro" que acabou expulso da cidade. "Esse rapaz foi a São Paulo e nunca mais voltou à Bahia" (QUEIROZ, 1985, p. 85).

A desistência do governo estadual em depor Horácio de Matos do poder no sertão teria sido influenciada por nova intervenção da presidência da República, que teria realizado "um acordo nessas lutas aqui na Bahia" (QUEIROZ, 1985, p. 84), “capitulado" pelo governo estadual, frente ao avanço da Coluna Prestes no Estado. Em 1926, logo após a Coluna cruzar as caatingas do território de Morro de Chapéu o próprio presidente Artur Bernardes envia telegramas autorizando que Horácio de Matos crie "Batalhões de Voluntários a fim de defenderem a Legalidade, combatendo os Rebeldes" (QUEIROZ, 1985, p. 86). As perseguições dos jagunços à Coluna terminam apenas na fronteira com a Bolívia.

O poder praticamente irrestrito dos coronéis somente será abalado em 1930, com a revolta que coloca Getúlio Vargas na presidência da República. Para se ter ideia de qual era a escala de influência dos coronéis foi a "revolução de 1930" que colocou fim ao sonho do prolongamento de "40 léguas" da via férrea, do França, em Queimadas, até a cidade.

Sob o pretexto de incentivar a indústria do salitre no município - o transporte do produto, na época, era feito "em costas de burro até Jacobina, para o embarque" (CUNEGUNDES, 1981, p. 38) -, o coronel Souza Benta e o então prefeito de Morro do Chapéu, Vicente Grassi, comerciante - cujos familiares eram os "pioneiros da indústria salitreira na Bahia", "proprietários, arrendatários e exploradores" da maior parte das minas do município, que "exportaram durante a Grande Guerra muitas toneladas desse minério" (CUNEGUNDES, 1981, p. 61) - definem o apoio da candidatura do Dr. Autran Dourado à Câmara Federal, em contraposição ao candidato do governador do Estado, sendo que este dependia do apoio em Morro do Chapéu.

Negociações no Rio de Janeiro teriam provocado o afastamento da candidatura do representante da família Dourado, "mediante compromisso firmado, e condição imposta, à ligação França-Morro do Chapéu, por via férrea, serviço que seria realizado no Governo Júlio Prestes” (CUNEGUNDES, 1981, p. 38). Com a revolução de 1930, “o protocolo [de entendimento] desapareceu, e Morro do Chapéu foi posto fora das cogitações" (CUNEGUNDES, 1981, p. 38). 
A "política frouxa e muito democrata"17 (QUEIROZ, 1985, p. 9) que caracterizou a cordialidade histórica dos coronéis de Morro do Chapéu com as demais autoridades foi reconhecida até por Virgulino "Ferreire", o Lampião, durante sua passagem pacífica pela cidade, em 1929 (CUNEGUNDES, 1981, p. 32). A postura possivelmente favoreceu a emancipação de diversos municípios a partir da área da freguesia de Morro do Chapéu.

Assim, a partir de 1930, ocorrem mudanças nas demais escalas de poder político e a estrutura política local passa a funcionar numa dinâmica diferente, apesar da força que as famílias tradicionais e os coronéis ainda exerciam. "Conheci muita gente boa que no dia 23 de outubro [de 1930] batia palmas às forças legais e no dia 24 já estava de gravata vermelha no pescoço, símbolo dos revolucionários de 1930" (QUEIROZ, 1985, p. 107). Para Cunegundes, "uma nova ordem foi imposta" (CUNEGUNDES, 1981, p. 39). Tanto Horácio de Matos quanto Souza Benta são presos e o sertão passa por um processo de desarmamento. Horácio de Matos é assassinado em Salvador, enquanto Souza Benta retorna ao Morro do Chapéu desmoralizado publicamente por um artigo do jornal Diário da Bahia (LOPES, 2006, p. 49). Mesmo assim, atua na política até a morte.

Como fora visto, assim como dominavam as esferas de decisão no local, os coronéis exerciam influência em outras escalas. Esta influência, por sua vez, também rebatia na escala local, fortalecendo ainda mais o poder destas autoridades.

Também as frações existentes dentro das classes dominantes transformaram o
Estado, em muitas ocasiões, em palco de intrincados e frequentemente
sanguinários conflitos no interior dos 'blocos de poder', que acabavam por se
refletir em toda a sociedade. São muitos os exemplos históricos de episódios
desse tipo, como o choque de interesses entre comerciantes, industriais e
senhores de terra, particularmente com estes últimos, já que em muitos casos
ainda fazia valer a sua força econômica e política, além das lutas específicas
pelas frações do poder (COSTA, 2008, p. 263).

Obviamente a hegemonia das classes dominantes não se deu sem que houvesse conflitos. A organização das classes menos favorecidas fez eclodir uma série de revoltas ao longo dos séculos na Bahia e no Nordeste. A formação de Palmares e dos quilombos nos sertões, as revoltas de Canudos, da Sabinada e os "acontecimentos políticos contra a ordem política instaurada pelo governo central" (COSTA, 1991, p. 35) ajudam a

\footnotetext{
${ }^{17}$ A observação está relacionada ao tratamento dado aos coronéis de Morro do Chapéu em relação aos coronéis das localidades vizinhas e, em algumas circunstâncias, às figuras do poder central estadual. Em relação à população local os coronéis exerciam uma relação autoritária de poder.
} 
explicar como se dava o equilíbrio de forças na sociedade e compreender como a resistência à opressão social era latente.

Vale destacar que "até poucos anos atrás governadores e prefeitos das capitais e de áreas de segurança nacional eram nomeados pelo governo central” (COSTA, 1991, p. 44) e que "o presidente nomeava os interventores em cada estado, segundo critérios de lealdade pessoal e política e também de conveniências em termos de arranjos da política regional e local que beneficiasse o governo central" (COSTA, 1991, p. 46).

\begin{abstract}
a prática política das classes dominantes, a oligarquia nordestina, pouco mudara desde há alguns séculos. O coronelismo, gênero de dominação na política regional, que se firmara no Império e na República Velha, ainda era exercido plenamente, controlando o poder político em suas várias escalas (local, estadual e regional). Em oposição a esse quadro de dominação, as classes populares agitavam-se em fins da década de 1950, pelas Ligas Camponesas e Sindicatos Rurais (COSTA, 1991, p. 57).
\end{abstract}

Os acordos e conflitos ocorridos ao longo da formação territorial de Morro do Chapéu podem ser considerados como disputas que "constituem uma expressão concreta da territorialidade dos conflitos" (CASTRO, 2005, p. 140) que se deram na sociedade de Morro do Chapéu, inserida no sistema de sociedades "complexas e desiguais" (CASTRO, 2005, p. 140), ao longo dos séculos. Isso significa que, "em toda disputa política há interesses que estão vinculados aos territórios em que os atores sociais habitam, trabalham, produzem riqueza e lutam para se apropriar de parte dela" (CASTRO, 2005, p. 140).

O espaço geográfico é intrinsecamente político, ou seja, ele é arena de conflitos e, consequentemente, de normas para a regulação que permite o seu controle. [...] Todo o processo de elaboração intelectual e das funções práticas das instituições políticas teve como objetivo o controle dos conflitos para que os projetos sociais, individuais e coletivos pudessem ser alcançados. Neste sentido, nas sociedades modernas, a organização institucional das democracias representativas foi uma resposta às demandas e às lutas de categorias organizadas da sociedade civil, como os sindicatos (CASTRO, 2005, p. 139).

É a evolução das lutas dos movimentos sociais e dos sindicatos, federações e confederações de trabalhadores rurais que permitirá a institucionalização e organização dos programas públicos analisados em Morro do Chapéu. Antes, porém, é importante ressaltar como a ação política e a articulação entre as oligarquias locais e as demais escalas de poder provocaram mudanças para a formação territorial do município. 


\subsection{Alinhamento local com escalas estadual e federal}

De um modo geral, a maior parte dos recursos públicos chega ao município de Morro do Chapéu por meio da influência dos políticos locais e do poder público local junto às esferas estadual e federal do governo. O serviço telegráfico, por exemplo, teria chegado ao município em 1929, por obra de Edgard Autran Dourado, oficial de gabinete do ministro da Viação, Victor Konder. O serviço teria sido uma mostra de gratidão pelo apoio do diretório municipal do PSD, do qual Jubilino Cunegundes fazia parte, à candidatura de Dourado à Câmara Federal (CUNEGUNDES, 1981, p. 41). Posteriormente, Dourado intercederia junto aos representantes do partido em favor da inclusão do nome de Cunegundes na chapa estadual para deputado para as eleições de 1947, indicação aprovada pela convenção do partido em Salvador.

Mesmo "com uma eleição tranqüila, vitória assegurada", o juiz decide "anular doze seções eleitorais nesta zona" e o resultado favorece o opositor, "Dr. Augusto Públio Pereira, amigo do então Governador Otávio Mangabeira. A substituição não prejudicou politicamente o Município, porque, por seu intermédio, conseguimos vários favores dos Governos Mangabeira e Régis Pacheco" (CUNEGUNDES, 1981, p. 42).

Na mesma época, partidários da União Democrática Nacional (UDN) nos distritos de Utinga e Riachão, em Morro do Chapéu, iniciam uma campanha visando a emancipação política. O movimento perde apoio frente às eleições municipais de $1947 \mathrm{e}$ o representante do PSD é eleito. Durante a gestão, que segue até 1951, inicia-se a construção do prédio da Usina Força e Luz e garante-se que o traçado da estrada do feijão atravesse a sede de Morro do Chapéu, "o serviço mais importante prestado ao Município" (CUNEGUNDES, 1981, p. 43). No final do mandato, o prefeito eleito filiase à UDN, o que, possivelmente, favorece a emancipação dos distritos de Riachão e Utinga e a criação do município de Utinga (BA), em 1953, com o apoio do governador. A esta se seguem outras emancipações.

No intuito de fortalecer o PSD e facilitar a administração, conseguiu-se pela Lei $\mathrm{n}^{\circ}$ 628, de 30 de junho de 1953, criar os distritos de Paz de Cafarnaum, Barro Alto, Lagoa do Boi e Mulungu do Morro, desmembrados do antigo distrito de Canarana, Várzea do Cerco e Camiri, desmembrados do distrito sede. Com essa demonstração de prestígio junto ao Governo Regis Pacheco, obteve-se outros favores para o Município (CUNEGUNDES, 1981, p. 44). 
Na gestão seguinte, de Manoel Dantas Brito, também do PSD, é inaugurado o Parque Rodoviário, o prédio da Biblioteca municipal e o Mercado Municipal. Com o apoio de verbas obtidas "pela Deputada Necy Novaes e pelo Deputado Manoel Novaes" (CUNEGUNDES, 1981, p. 44) também são construídos o lactário e o prédio do Hospital.

Durante o mandato do militar Juracy Magalhães no governo do Estado, uma série de obras é realizada no município. A construção da ponte de cimento armado sobre o rio Montevidéu possibilita o acesso da sede ao povoado de Duas Barras, por meio de uma estrada carroçável que passa por Lagoa Nova. "Foram abertos grandes Tanques em Lagoa Nova, Passagem, Duas Barras e Fedegosos, realizando um serviço importante para o abastecimento de água no povoado do Icó” (CUNEGUNDES, 1981, p. 47).

É importante considerar que conforme os "lavristas" deixaram os garimpos e voltavam para suas regiões de origem após o declínio da mineração e a agricultura e a pecuária retomaram a posição de principais atividades econômicas do município, apesar das obras empreendidas, principalmente, pelo governo estadual, a situação de penúria social na maior parte da zona rural de Morro do Chapéu continuava praticamente a mesma de três séculos antes. As obras e serviços tinham mais a finalidade de manter as áreas de interesse sob o controle das elites locais que promover o desenvolvimento econômico das localidades.

A movimentação dos adversários para acabar com a hegemonia do PSD, que utilizava como "palco das lutas políticas para o lançamento das candidaturas" (CUNEGUNDES, 1981, p. 44) o teatro da cidade, resulta na criação de diretórios municipais de outros partidos, entre eles os do Partido Comunista Brasileiro, da ação Integralista Brasileira e do Partido Republicano. A obediência das chefias deste partido ao deputado Manoel Novaes, nos distritos nos quais tinham representatividade, favoreceu a emancipação dos municípios de "Cafarnaum, com o distrito de Mulungu do Morro $^{18}$; e Canarana, com os distritos de Barro Alto e Lagoa do Boi ${ }^{19,}$ (CUNEGUNDES, 1981, p. 41). O PSD de Morro do Chapéu apoiou estas chefias, que saíram vitoriosas nas primeiras eleições realizadas nos novos municípios.

A instalação do serviço de água na cidade também teria contado com a ajuda do deputado Manoel Novaes "a quem o sertão, em grande parte, deve o seu desenvolvimento" (CUNEGUNDES, 1981, p. 49), durante um período no qual o poder

\footnotetext{
${ }^{18}$ Pelo decreto estadual $\mathrm{n}^{\mathrm{o}} 1719$, de junho de 1962 (CUNEGUNDES, 1981, p.47)

${ }^{19}$ Pelo decreto estadual no 1725 , de junho de 1962 (CUNEGUNDES, 1981, p.47)
} 
público do município sofria "as consequências das restrições e determinações da nova política implantada com a Revolução de março de 1964" (CUNEGUNDES, 1981, p. 48, grifo nosso). Nas eleições seguintes, a UDN, sob a denominação de Arena 1, após 20 anos de tentativas, elege o representante à prefeitura do município. No período é instalado o serviço telefônico em Morro do Chapéu.

Lourival Cunegundes, da Arena 2, elege-se prefeito para o mandato seguinte, que segue até 1973. Neste período, "mais de setenta escolas em várias localidades do Município" (CUNEGUNDES, 1981, p. 49) eram mantidas em funcionamento. Para efeito de comparação, "em 1898, havia apenas uma escola estadual com 28 alunos matriculados" (SAMPAIO, 2009, p. 88) em Morro do Chapéu. Especialmente durante o período em que o grupo político chefiado pelo coronel Dias Coelho se mantém no poder há um salto no número de escolas e de alunos matriculados. "Mesmo não sendo diretamente intencional, havia uma relação da alfabetização no município, com os propósitos eleitorais" (SAMPAIO, 2009, p. 91) e o grupo do coronel foi o principal beneficiado.

Em 1971 uma agência do Instituto Nacional de Previdência Social (INPS) é inaugurada no município para atender os cidadãos de um amplo território que se estendia até a Chapada Velha e a região das Lavras Diamantinas. O serviço de energia é instalado no município em 1974. Outra prova importante de como as obras empreendidas pelo Estado e o governo federal atendiam às necessidades dos próprios governos é a reforma do aeroporto municipal, autorizada pelo governo estadual e realizada em 1971 por conta da visita do governador Antonio Carlos Magalhães. Em 1974, o Serviço de energia de Paulo Afonso é instalado e o primeiro serviço de asfaltamento da estrada do feijão é entregue.

A partir de então ocorre a intensificação da instalação de aguadas, pontes, barragens, escolas nos povoados e demais objetos técnicos no território do município. Em 1995, na localidade do Icó, por exemplo, já havia escolas municipais e estaduais de $1^{\mathrm{o}}$ grau, posto de saúde, energia elétrica e serviço telefônico. Em Fedegosos, a mesma estrutura com a diferença da existência do serviço público de abastecimento de água. No Velame e nas localidades próximas foram implantadas apenas escolas municipais de $1^{\circ}$ grau. O posto de saúde mais próximo, única estrutura diferenciada, fica a alguns quilômetros de distância do povoado (ROCHA, COSTA, 1995a).

No caso do Icó, obras e benfeitorias foram trazidas por um vereador que vem sendo eleito sucessivamente por sete mandatos. Para o agricultor, Rosemiro José da 
Silva, desde que chegou à localidade, no final da década de 1950, "os representantes da cidade, chefes, prefeitos, vereadores, todos foram se interessando" (Rosemiro José da Silva, 2011, propriedade do entrevistado) pelo povoado, o que rendeu algumas melhorias, como o poço artesiano comunitário. É importante ressaltar que as disputas pelo poder dentro da Câmara de Vereadores do município também representam benefícios para algumas localidades em detrimento de outras.

Alguns chefes políticos não precisaram necessariamente ocupar o cargo de prefeito para serem reconhecidos como líderes políticos. $\mathrm{O}$ próprio Jubilino Cunegundes, por exemplo, nascido em 1899, mesmo tendo sido candidato a deputado, na escala política formal local ocupou apenas o cargo de vereador. No entanto, o fez por nove mandatos. Cunegundes saíra da região de Utinga com quase 16 anos com uma carta de referência para trabalhar em Morro do Chapéu, na firma comercial Grassi \& Cia, e posteriormente passou a exercer a ocupação de advogado nas comarcas da região (CUNEGUNDES, 1981, p. 5).

Depois de trabalhar para Tolentino Oliver Guimarães, vereador do município entre 1948 e 1954, o agricultor Rosemiro José da Silva adquiriu a propriedade que possui no Icó de Cunegundes, em 1959. Neste mesmo ano, Lourival Guimarães Cunegundes, filho de Jubilino, é eleito pela primeira vez prefeito de Morro do Chapéu.

\footnotetext{
O Icó era uma grande fazenda que quase fazia divisa com o Morro do Chapéu. Quando esse dono morreu os herdeiros deram o inventário para esse chefe Jubilino fazer, ele era o chefe da cidade, era advogado, e deram a metade das terras para ele. Foi esta parte dele que ele vendeu. Eu comprei e paguei logo, mas muitos não tinham condição, ele vendia fiado, para a pessoa ir pagando com as condições que a pessoa fosse dando. Outros ele levou para o banco para a pessoa trabalhar pelo banco e ir pagando (Rosemiro José da Silva, 2011, propriedade do entrevistado).
}

É importante destacar no relato de Rosemiro a associação, pelo menos desde meados do século XX, entre os atores hegemônicos da política local e os atores do sistema financeiro, representado pela figura das instituições bancárias. Esta relação evolui de várias formas ao longo das décadas seguintes, como será visto mais à frente, expondo a dependência dos trabalhadores rurais ao sistema financeiro, um ator cujas relações globalizadas se destacam.

Vale ainda destacar que na esfera política a predominância dos coronéis, intendentes, prefeitos, juízes, integrantes de grupos políticos, pessoas que ocupavam cargos de decisão na esfera local e regional, comerciantes, das "famílias numerosas" e 
de pequenos trabalhadores proprietários, coexistia com uma massa de agricultores e famílias que exerciam principalmente a função de eleitorado. Ao passo em que eram vítimas de ameaças e da intimidação de partidários dos diferentes grupos, especialmente, durante os processos eleitorais - "mecanismo que funcionava desde a véspera [da eleição], com a chegada dos eleitores que vinham a cavalo dos arraiais e fazendas para os currais eleitorais dos Coronéis da época" (CUNEGUNDES, 1981, p. 91) -, sofriam as conseqüências sociais da exclusão, principalmente durante os sucessivos períodos de estiagem.

Numa das secas já citadas, entre 1898 e 1900, enquanto a elite dos comerciantes de diamantes sucedia os antigos pecuaristas, "que se afastaram das fazendas abandonadas" (SAMPAIO, 2009, p. 95) promovendo a degradação de pastagens e construções, um fluxo migratório de pessoas foi promovido pelo governo do Estado com destino a Salvador. "Sem a ajuda do governo para se sustentar, os flagelados se transformaram em sem tetos e mendigos na capital" (SAMPAIO, 2009, p. 95).

A migração temporária de trabalhadores rurais da Bahia para as capitais do Nordeste e de outras regiões foi identificada como um dos tipos mais significativos de migração (MARTINS, 1988, p. 53). A questão é que as grandes secas que assolaram sucessivamente áreas como Morro do Chapéu ao longo dos séculos promoveram outro tipo de migração ainda mais prejudicial, a definitiva.

Calamidades pequenas e grandes - como as doenças e as secas - têm um efeito social desastroso em sua vida (do camponês), levando até ao endividamento e à migração definitiva. Esse camponês vive no limite entre o ficar e o partir definitivamente (MARTINS, 1988, p. 53).

O desenvolvimento de formas que promovessem a manutenção do homem no campo e a adoção dos discursos cooperativista e associativista foram estratégias utilizadas pela Coopaf para atrair os agricultores familiares a produzirem para o Programa Nacional de Uso e Produção do Biodiesel (PNPB) e o Programa de Aquisição de Alimentos (PAA). Para tanto, a organização da cooperativa e o trabalho do grupo ligado à entidade requereram o apoio de organizações de trabalhadores rurais alinhadas ao projeto político representado pela gestão do governo federal que implementou ambos programas. Além disso, há líderes políticos deste grupo que favoreceram a cooperativa beneficiando tanto a emergência política, em escala estadual e federal, do grupo que 
representavam, quanto à daqueles responsáveis pela implementação dos programas em escala local.

Considerando que ambos os programas analisados compõem políticas públicas de cunho econômico e social e que, como fora visto, vêm no encalço de uma série de políticas territoriais "implícitas" (COSTA, 1991, p. 73) citadas anteriormente, que se desenvolveram, principalmente, no século XXI, e de "políticas econômico-territoriais", "subestratégias das macropolíticas econômicas" (COSTA, 1991, p. 74) - no caso do PNPB, da política de substituição de combustíveis fósseis por biocombustíveis; e do PAA, da política de garantia da segurança alimentar e da inclusão social na sociedade do consumo ${ }^{20}-$, é importante ressaltar que:

\begin{abstract}
Não há dúvida de que não podemos atribuir às políticas territoriais, a exclusividade como força motriz nas mudanças ao nível da formação e da estrutura do território nacional. Muito do que observamos hoje na realidade brasileira, quanto a esse aspecto, é resultado da combinação de variadas determinações ao longo da história, nas quais a participação do Estado, se não for nula, não chegou a credenciá-lo como principal protagonista dessa evolução. Entretanto [...] alguns dos principais processos de construção do espaço nacional tiveram e ainda têm a sua inspiração e mesmo algum tipo de concretização a partir das iniciativas estatais para o setor (COSTA, 1991, p. 73).
\end{abstract}

É possível verificar que as principais redes produtivas estabelecidas na escala local, em Morro do Chapéu, ao longo dos séculos, tiveram origem nas esferas de decisão internacional. À escala de decisão nacional coube apenas a adequação territorial necessária às atividades e à escala local a organização destas iniciativas. No caso da exploração dos diamantes e carbonatos no município, as firmas européias incentivavam a produção, mantendo estreitos laços com os coronéis locais ${ }^{21}$. Os fluxos das mercadorias saíam dos garimpos para as casas comerciais na sede e de lá para Salvador e a Europa.

A pecuária, como fora visto, inicialmente tinha o objetivo de fomentar a produção açucareira destinada ao exterior, uma das atividades mais importantes da economia colonial. O fluxo de animais que saíam do município tinha como destino

\footnotetext{
${ }^{20} \mathrm{O}$ termo está relacionado às ações políticas "pelas quais os consumidores ascendem à condição de cidadãos [que implicaria numa] concepção de mercado não como simples lugar de troca de mercadorias, mas como parte de interações socioculturais mais complexas" (CANCLINI, 1991, p. 90). Neste sentido, o "valor mercantil" também "não é uma coisa contida naturalisticamente nos objetos, mas é resultante das interações socioculturais em que os homens os usam" (CANCLINI, 1991, p. 90).

${ }^{21}$ A imagem de Nossa Senhora da Soledade, de tamanho e carga expressivos, até hoje exposta na capela da casa onde morou Francisco Dias Coelho, na sede de Morro do Chapéu, fora um presente dado pela firma Levy, de Paris, ao coronel.
} 
Feira de Santana, o Recôncavo baiano e, mais tarde, outras regiões como o Sudeste, especialmente, Minas Gerais.

A agricultura em Morro do Chapéu é a única atividade dentre as analisadas que tem como principal finalidade a subsistência da população local, incluindo as atividades do PAA, seja pelo consumo dos gêneros produzidos ou pela venda do excedente para o consumo de gêneros domésticos. Os fluxos de produtos agrícolas vêm da zona rural em direção à sede.

Já a produção de biodiesel foi motivada pelo governo federal a partir de pressões externas, como a dos movimentos ambientalistas, conforme foi visto anteriormente. No entanto, por enquanto, a função é atender ao mercado de consumo interno, apesar da produção de soja no oeste baiano e na região Centro-Oeste ter perspectivas de ser exportada. Os fluxos da mamona também são oriundos da zona rural com destino à sede de Morro do Chapéu e de lá para as usinas produtoras do óleo, primeiro na própria Chapada Diamantina, em Iraquara, e depois em Candeias (BA).

No caso da mamona, além das fontes de macro-poder citadas anteriormente, há outra série de "micro-poderes", uma espécie de "rede de aparelhos dispersos, sem aparelho único, sem foco nem centro, e uma coordenação transversal de instituições e de tecnologias" (FOUCAULT, 1979, p. 159) que influenciam os territórios da cultura, especialmente, ao se analisar o caso específico de Morro do Chapéu.

\footnotetext{
De modo que, se quisermos apreender os mecanismos de poder em sua complexidade e detalhe, não poderemos nos ater unicamente à análise dos aparelhos do Estado. [...] De fato, o poder em seu exercício vai muito mais longe, passa por canais muito mais sutis, é muito mais ambíguo, porque cada um de nós é, no fundo, titular de um certo poder e, por isso, veicula o poder. O poder não tem por função única reproduzir as relações de produção. As redes da dominação e os circuitos da exploração se recobrem, se apóiam e interferem uns nos outros, mas não coincidem (FOUCAULT, 1979, p. 159).
}

A possibilidade de analisar alguns desses "mecanismos e efeitos de poder" (FOUCAULT, 1979, p. 161) não representa a redução da importância nem da "eficácia do poder de Estado" (FOUCAULT, 1979, p. 161). A iniciativa visa dar visibilidade às demais forças que influenciam o objeto da pesquisa, principalmente, na escala local e cuja representatividade para a formação do território e no processo considerado a partir de 2007 exige que sejam considerados. 


\subsection{Política da mamona e o controle sobre fluxos}

A intensificação da influência de entidades estaduais e federais do movimento sindical de trabalhadores rurais no STR-MC é um dos principais fatores de articulação da Coopaf. A cooperativa surge em 2005, em meio aos debates de consolidação do PNPB e do lançamento do marco regulatório do programa. O grupo responsável pela administração da Coopaf foi formado por integrantes dos movimentos sindicais, sociais e político-partidários de Morro do Chapéu e contou com a orientação de entidades de classe, além do principal articulador do PNPB, o próprio governo federal.

O aumento da circulação de recursos financeiros e mercadorias promovido pela Coopaf em Morro do Chapéu e na região a partir de 2007 por conta do PNPB e do PAA intensificou os fluxos nas redes de produção de mamona e de alimentos numa escala que ultrapassou os limites do município e adentrou, principalmente, o território de identidade de Irecê e da Chapada Diamantina. A atuação da cooperativa alterou o equilíbrio de poder histórico nos territórios da mamona nesta região, especialmente no que diz respeito à intermediação da compra da produção da agricultura familiar e revenda. $\mathrm{O}$ destino das safras deixou de ser exclusivamente a indústria ricinoquímica e passou a ser também a indústria dos biocombustíveis.

Se os capangueiros eram os intermediários da atividade mineradora em Morro do Chapéu, os atravessadores são os atores históricos nesta função na agricultura e da mesma forma atuam dentro da cadeia da mamona. São centenas de pequenos negociantes de diversas localidades que financiam e compram a produção dos agricultores a fim de lucrar revendendo-a, no caso das áreas analisadas, para um grande negociante que concentra o estoque, controla os preços e fornece para as indústrias. Geralmente, esta relação prejudica o agricultor, que fornece produtos com preço defasado e que, sem força para se organizar, não consegue melhorar as condições de comercialização.

Rosemiro, do Icó, refere-se ao principal atravessador da região como o "chefe" dos compradores de diversas localidades que levam o produto ao depósito mantido na cidade de Várzea Nova. O agricultor expõe a contradição do incentivo ao cultivo da mamona, uma cultura cujos preços são definidos pelas leis de mercado e um gênero não alimentício, e os riscos da variação do valor da cultura - especialmente nos períodos em 
que os atravessadores são os principais definidores do preço - para a soberania alimentar dos trabalhadores rurais.

Então, quer dizer, ele [atravessador] apodera. Se não fosse a firma (Coopaf), ele estava comprando pelo preço que queria. Porque quando é uma mercadoria, um milho, um feijão, se no caso eu dissesse: "eu não vou me sujeitar a vender baratinho. Eu vou comer, vou botar na feira, no comércio". Vende um quilo pro senhor, um quilo pra outro acolá, outro acolá. Dou a um vizinho meu, bato, divido com a minha família, nós se alimenta. Mas e a mamona que não tem como? (Rosemiro José da Silva, 2012, casa do entrevistado).

A falta de disponibilidade de crédito para a agricultura familiar é um dos principais motivos que justificam a existência dos atravessadores, que atuam nas localidades ao longo de muitos anos, o que faz o agricultor adquirir "confiança" (Fábio Pinto, 2011, no STR-MC) nestas figuras. Para Lula, do Velame, a prática dos atravessadores "escraviza os agricultores" (Luciano Bernardes de Brito, 2012, propriedade do entrevistado).

O agricultor tem a necessidade de limpar ou fazer a roça e ele já habitua naquilo: "eu vou no depósito e pego o dinheiro de tantas sacas". É o que se chama aqui de casamento no civil. Já está amarrado. Além desta questão de ir diretamente no depósito vender uma produção antecipada. Vende a mamona quando ela está começando a florar. Vende a flor da mamona (Luciano Bernardes de Brito, 2012, propriedade do entrevistado).

A influência da Coopaf sobre os fluxos da cadeia produtiva da mamona a partir do PNPB fez a cooperativa exercer um papel decisivo na estrutura da cadeia da cultura, especialmente no que diz respeito à melhoria das condições de cultivo e comercialização dos agricultores. Esse papel é fundamentado na organização social, na organização dos agricultores e na influência dos movimentos sindicais e políticos.

Nascido em Salvador, Érico Sampaio de Souza, foi o diretor presidente da Coopaf que permaneceu mais tempo no cargo. Durante sua gestão é que os programas analisados passaram a ser executados pela cooperativa. Formado técnico agrícola, pelo menos desde 2001 manteve envolvimento com a Federação dos Trabalhadores da Agricultura Familiar do Estado da Bahia ${ }^{22}$ (Fetag-BA) e pouco depois se tornou diretor do STR-MC. De acordo com Érico, o envolvimento com o cooperativismo começou em 2003 por conta de um projeto liderado pela Confederação Nacional dos Trabalhadores

\footnotetext{
${ }^{22}$ Em reportagem do jornal A Tarde, de setembro de 2001, é possível ver Érico Sampaio posando ao lado do então presidente da Fetag-BA, Edson Sampaio Pimenta (FARIAS, 2001, p.3). O mesmo sobrenome atesta o grau de parentesco de ambos.
} 
na Agricultura (Contag) e pela Fetag-BA. "Passamos dois anos com bastante atividade na área do cooperativismo e em dezembro de dois mil e cinco nasceu a Coopaf" (Érico Sampaio de Souza, 2011, laticínio da Coopaf), coincidentemente, no período de criação do PNPB.

Por conta do envolvimento junto à Fetag-BA, Érico participa de uma apresentação organizada em Salvador pela BrasilEcodiesel, empresa que instalara uma usina de beneficiamento de biodiesel em Iraquara, na Chapada Diamantina, para solicitar o apoio do movimento sindical, dada a exigência do PNPB da participação da agricultura familiar no fornecimento de sementes e erradicação da pobreza.

\begin{abstract}
Naquela época o desenho do programa de biodiesel era de contratos individuais dos produtores com a empresa. Quando começaram os trabalhos a gente viu a dificuldade. Por que era uma indústria cumprindo o papel de organizar o agricultor familiar. Então caiu a nossa ficha de que se a agricultura familiar no Nordeste quisesse de fato se consolidar no biodiesel, teria que cumprir um papel mínimo de organização de bases. Aí no final do ano, nós criamos a Coopaf (Érico Sampaio de Souza, 2011, laticínio da Coopaf).
\end{abstract}

A localização da cooperativa próxima à principal região produtora de mamona é um dos motivos que justificam a fixação na sede em Morro do Chapéu. A necessidade de formação de "um instrumento legal" (Érico Sampaio de Souza, 2011, laticínio da Coopaf) de subsídio à comercialização da mamona produzida pela agricultura familiar da região e destinada ao PNPB é que justificaria o surgimento da Coopaf ${ }^{23}$. Desde a origem da cooperativa, há estreitos laços entre a instituição e o STR-MC. O presidente do sindicato, Fábio Pinto, explica a relação entre as organizações.

O sindicato é uma entidade representativa, tem sua autonomia, sua independência, assim como a cooperativa. A Coopaf nasceu dentro do movimento sindical. Foi um projeto articulado, principalmente, dentro da Fetag-BA. Não tem como não ter uma parceria muito forte, um elo muito grande entre estas duas entidades. $\mathrm{O}$ sindicato trabalha de uma forma mais ampla, representando o trabalhador. A cooperativa seria o instrumento de comercialização e produção que o movimento sindical tem para representar estes trabalhadores (Fábio Pinto, 2011, no STR-MC).

O fortalecimento da Coopaf, no entanto, ocorre em parceria com organizações da sociedades civil previamente existentes em Morro do Chapéu. Vale lembrar que as atividades ligadas ao PAA dependiam do auxílio de associações, especialmente as

\footnotetext{
23 "Em junho de 2005, quando eu era diretor do STR-MC, nós chegamos a vender 500 toneladas de mamona à Brasil Ecodiesel, via sindicato. Mas o sindicato não é uma instituição constituída pra fazer comercialização" (Érico Sampaio de Souza, 2011, laticínio da Coopaf).
} 
comunitárias, localizadas na sede do município. Os povoados do Velame, da Malhada de Areia, do Icó e de Fedegosos, por exemplo, já possuíam associações comunitárias ativas, que participaram em maior ou em menor medida das atividades do PNPB e do PAA.

Outro grupo de pessoas ligadas à Coopaf e ao STR-MC estava previamente organizado na Associação dos Pequenos Produtores da Chapada Diamantina (APPC), pela qual acessaram verbas do Programa Nacional da Agricultura Familiar (Pronaf), na modalidade Jovem, destinada ao assentamento de filhos de produtores rurais. $\mathrm{O}$ grupo da associação chegou a plantar girassol em uma área coletiva da propriedade financiada e forneceu, em regime experimental, sementes para o programa do biodiesel.

É importante considerar que há outra série de cooperativas e associações comunitárias, de produtores de gêneros rurais, de artesanato, entre outros ramos de atividade no município. Do mesmo modo há diversos assentamentos de trabalhadores rurais que foram instalados nos últimos anos dentro do território de Morro do Chapéu, muitos deles reconhecidos localmente como fruto das lutas dos movimentos sociais de luta pela terra, como o Movimento dos Trabalhadores Rurais Sem Terra (MST), ou da atuação do STR-MC. Há ainda a existência daquelas comunidades já reconhecidas como de remanescentes quilombolas, como é o caso do Velame.

Isso mostra que já havia certo nível de organização social no município, tanto na área urbana quanto na rural, antes do início das atividades da Coopaf. No entanto, as atividades da cooperativa podem ter resultado numa maior mobilização da própria sociedade civil organizada que passou a exercer outras formas de "pressão popular" (Fábio Pinto, 2011, STR-MC).

\footnotetext{
A questão social, a questão política, faz com que as comunidades comecem a identificar os problemas existentes ali e comecem a buscar soluções para aquilo. Influenciam o poder público. E na questão da educação também, porque o próprio programa (PNPB) exige diferentes programas de assistência técnica, dias de campo. Isso abre a mente do agricultor e do trabalhador rural (Fábio Pinto, 2011, STR-MC).
}

As próprias atividades relacionadas à cooperativa contribuíram para a formação de um grupo de indivíduos na escala local que, de alguma forma, se identificavam com as atividades relacionadas à cooperativa. $\mathrm{O}$ grupo de profissionais diretamente ligado às atividades da Coopaf, por sua vez, também possuía atuação político-partidária no município. Por meio desta conseguiu organizar a realização de um curso técnico regular 
de formação agrícola para uma escola estadual de ensino médio que leva o nome do exchefe político Jubilino Cunegundes, localizada na sede do município.

\subsection{Coopaf e emergência de um novo grupo político}

A esfera administrativo-política do município também passou por mudanças relacionadas ao surgimento e a atuação da Coopaf. Alguns dos representantes do movimento sindical que contribuem para a criação da cooperativa elegem-se deputados estaduais. $\mathrm{Na}$ esfera local esta relação pode estar associada ao surgimento do diretório municipal da União da Juventude Socialista (UJS), entidade ligada ao PCdoB. São os integrantes da UJS no município, junto com as lideranças formadas no STR-MC, que posteriormente fortalecem o diretório municipal do partido.

A ascensão do grupo em Morro do Chapéu também representa a territorialização dos interesses dos deputados ligados ao movimento sindical na escala local, em especial de Edson Pimenta, na época no PCdoB. A intensificação da influência destes atores tem como finalidade a garantia do apoio do eleitorado, no caso, da base dos trabalhadores rurais. A articulação dos agricultores e a defesa dos direitos da categoria promovidos pelo STR-MC, a atuação produtiva da Coopaf e a ação política do PCdoB na escala local provoca o apoio dos personagens envolvidos com os atores do partido no Estado nas campanhas eleitorais municipais e estaduais.

Esta lógica afeta as dinâmicas do equilíbrio de poder em Morro do Chapéu, cujo colégio eleitoral é dividido entre eleitores de determinados representantes das escalas estadual, federal e local, o que passa a gerar conflitos entre os correligionários dos diferentes grupos. Na escala local, o grupo político vinculado à UJS, ao STR-MC, ao PCdoB e, posteriormente, à Coopaf, ensaia uma participação mais ativa na administração pública nas eleições municipais de 2004, integrando formalmente a coligação $^{24}$ que elege o candidato Aliomar da Rocha Soares, do Partido Liberal (PL). O ex-prefeito eleito já havia dirigido a cidade entre 1997 e 2001.

Com a vitória, o grupo assume a pasta municipal ligada à Agricultura, mas logo rompe com a equipe que controla a prefeitura e a Câmara de Vereadores. A partir daí o

\footnotetext{
${ }^{24}$ A coligação era formada por quatro partidos: PL, PCdoB, PSC e PPS. Disputa ainda o pleito uma coligação encabeçada pelo PT com o PV e outra com o PP na cabeça de chapa junto com o PFL e PSC. PMDB, PSDB, PTN e PDT lançam candidatos a vereador sem participar formalmente de coligações. Isso não impede que vereadores eleitores destes partidos apóiem o grupo que assume o poder no município.
} 
grupo se consolida como oposição, alinhado ao governo federal, aos deputados do PCdoB com atuação na questão agrária e ao governo estadual a partir de $2006^{25}$. É possível considerar o trabalho com os programas públicos, como o PNPB e o PAA, como uma das principais forças motrizes para a emergência política local do grupo.

O apoio dos programas federais analisados à agricultura familiar não fortalece apenas os representantes políticos do grupo originado no movimento sindical, mas também as bases do grupo. Os pequenos produtores deixam de depender apenas da solidariedade do poder público local formal para sanar as necessidades, relação contaminada pelo senso da troca de favores que perpetua o poder local nas mãos dos atores para quem se deve obediência pela ajuda prestada.

Na prática, a mediação de uma cooperativa, que tem personagens mais próximos dos produtores rurais, como os técnicos agrícolas, às vezes contratados nas próprias comunidades para prestarem serviços, reduz a distância entre o camponês e as iniciativas do governo federal e altera o equilíbrio de forças instituído na região. $\mathrm{O}$ PNPB e o PAA não exigem o envolvimento da administração pública formal local para se constituírem.

O processo de valorização do preço da saca da mamona iniciado no começo do programa do biodiesel se intensifica com a criação da Petrobras Biocombustíveis (PBio). O volume maior de recursos financeiros controlados pela Coopaf, provocado, principalmente, pelo aumento dos fluxos relacionados à produção e comercialização da mamona, beneficia tanto a agricultura familiar da região, que passa a ser melhor remunerada com a valorização do produto, quanto o grupo político ligado à cooperativa, que com mais recursos exerce maior influência sobre diversas localidades, principalmente naquelas analisadas, como será visto no próximo capítulo.

Para o presidente do STR-MC, Fábio Pinto, a consolidação da cooperativa representou muito para a realidade política de Morro do Chapéu. Em 2011, antes do pleito municipal do ano seguinte, o sindicalista dividia o jogo político local em dois grupos principais: aquele representado pelo prefeito eleito em 2008 e o grupo ligado à Coopaf. De acordo com o sindicalista, a ascensão deste grupo fez os dois se movimentarem para angariar apoio da população. "Ter uma nova opção fez todos os

\footnotetext{
${ }^{25}$ Jornais impressos publicados com incentivos da Coopaf durante os anos de 2007 e 2008 dão destaque para imagens do diretor presidente Érico Sampaio ao lado do então deputado estadual Edson Pimenta, do ex-presidente da Petrobras, Sérgio Gabrielli (CORREARD, 2008a, p.1), do governador da Bahia, Jaques Wagner (CORREARD, 2008b, p.1), além de dedicar uma manchete para o ex-presidente Luiz Inácio Lula da Silva, na ocasião da inauguração da fábrica da BrasilEcodiesel, em Iraquara (RICARDO, 2007, p.1).
} 
políticos atentarem para uma disputa que, de fato, nunca aconteceu aqui no município" (Fábio Pinto, 2011, STR-MC).

Prova da polarização da influência dos dois grupos na política local é o tratamento dedicado aos representantes do poder público local ao grupo ligado à Coopaf. O diretor operacional da cooperativa, Fabrício Amorim, ressalta que, apesar da organização prestar um serviço significativo aos cooperados e à sociedade de Morro do Chapéu e pagar um volume representativo de impostos à prefeitura, não recebe nenhum tipo de apoio do poder público local. De acordo com ele, o poder público municipal chega a atrapalhar o desenvolvimento das atividades da entidade. "A cooperativa sofre uma perseguição política por questões de visão partidária diferente entre um lado e outro, de algumas pessoas de um lado e algumas pessoas de outro" (Fabrício Amorim, 2011, residência do entrevistado).

\begin{abstract}
A gente tem um prejuízo realmente grande, nesta região nossa aqui, a questão política nos municípios do porte de Morro do Chapéu é uma coisa quase que pessoal. As famílias envolvidas no processo são muito próximas, de um lado e do outro, existem até brigas dentro da própria família, uns estão de um lado e outros do outro politicamente. Em Morro do Chapéu não deixa de ser diferente e a cooperativa também sente este impacto. Esta visão diferente de algumas pessoas de ambos os lados, politicamente divergentes, acaba prejudicando até o programa [do biodiesel] em Morro do Chapéu. [...] Ao contrário de outros municípios onde a prefeitura tem parceria com a cooperativa e o resultado é bom para todo mundo (Fabrício Amorim, 2011, residência do entrevistado).
\end{abstract}

Nas eleições municipais de 2008 já era evidente a disputa entre os dois grupos. $\mathrm{O}$ prefeito lança a candidatura à reeleição com o apoio da maioria dos diretórios de partidos políticos da cidade ${ }^{26}$. O grupo político ligado à Coopaf e ao PCdoB local se une ao diretório municipal do Partido dos Trabalhadores (PT) em coligação e oficializa a candidatura de Érico Sampaio à prefeitura. Outros dois candidatos participam da $\operatorname{disputa}^{27}$. Nos dias que antecedem o pleito, no entanto, o prefeito renuncia ${ }^{28}$ à condição

\footnotetext{
${ }^{26}$ A coligação que apóia a reeleição de Aliomar da Rocha Soares, na época filiado ao PMDB, na campanha eleitoral de 2008 era formada pelos seguintes partidos: PSL, PMDB, DEM, PV, PSC, PR, PSDB, PP e PRTB.

${ }^{27}$ Virgílio Ferraz Ribeiro, do PRB, que teve o apoio do PDT, e Wilson Dourado Lima, do PTC. Ambos já haviam sido prefeitos do município: o primeiro entre 1989 e 1992 e o segundo, em duas oportunidades, entre 1977 e 1983 e de 1993 a 1996.

${ }_{28}$ Os processos judiciais relacionados a irregularidades identificadas pelo TCU (Tribunal de Contas da União) - disponíveis através do Cadastro de Responsáveis com Contas Julgadas Irregulares - nas prestações de contas de convênios com fundos nacionais das áreas de educação e saúde, sob responsabilidade do ex-prefeito, poderiam colocar em risco a possível reeleição. Aliomar da Rocha Soares já foi condenado em um destes processos (BRASIL, 2010, p. 116), referente à primeira gestão do ex-prefeito.
} 
de candidato em benefício do presidente da Câmara de Vereadores do município, Cleová Oliveira Barreto, que é eleito com 54,3\% dos votos válidos ${ }^{29}$.

Tentar-se-á analisar a partir daqui não o funcionamento do sistema eleitoral em vigor, mas sim o resultado das eleições que se seguem à articulação do grupo ligado à Coopaf e como isso rebate nos arranjos socioeconômicos e territoriais do município. Os processos eleitorais podem ser analisados por meio daquilo que é conhecido como "razões espaciais, ou seja, as muitas condições que no território cercam a existência humana, como a localização, a vizinhança, a densidade demográfica, as instituições, os equipamentos à disposição dos cidadãos etc.” (CASTRO, 2005, p. 159). Neste caso, o interesse principal são as relações entre as articulações promovidas a partir da cooperativa e os resultados eleitorais obtidos por conta da influência política. Neste sentido, a organização de dados que representam as informações de um "mapa dos votos ou das opções eleitorais" contribui como um "instrumento de exame" (FOUCAULT, 1979, p.161-162).

O resultado da disputa eleitoral de 2008 mostra o equilíbrio entre o eleitorado de ambos os grupos, especialmente, na sede de Morro do Chapéu. Enquanto a diferença dos votos válidos na sede foi de $51,1 \%$ para o grupo do prefeito, contra $45,5 \%$ para o grupo da Coopaf, na zona rural o resultado foi ligeiramente mais acentuado - $55 \%$ contra $39 \%$, respectivamente. A votação representativa obtida pelo grupo vinculado à cooperativa na sede pode ser dedicada à localização do escritório da Coopaf na localidade e o fluxo de recursos financeiros que circulavam a partir deste objeto técnico.

O poder de influência da cooperativa na sede, que concentrava os fluxos comunicacionais e comerciais estabelecidos por trabalhadores e cooperados, assim como o fluxo de mercadorias e veículos relacionados ao grupo, pode ajudar a explicar a votação expressiva do grupo no território urbano do município.

Para o sindicalista Fábio Pinto, o aumento da renda - com a valorização do preço da mamona e de gêneros alimentícios - e do emprego, tanto nas áreas rurais com a contratação de trabalhadores diaristas e locação de serviços de máquinas - quanto na sede - com a contratação de técnicos agrícolas e de funcionários da Coopaf e a

\footnotetext{
${ }^{29}$ A renúncia do candidato a prefeito Aliomar da Rocha aconteceu nas vésperas das eleições o que impediu que tanto o nome, quanto a fotografia e o número do partido político ao qual pertencia fossem substituídos nas urnas eleitorais. Na prática, os eleitores votaram no número do candidato que havia renunciado, observando sua fotografia e seu nome e elegeram Cleová Barreto, candidato que pertencia a outro partido político (MORENDE, 2008).
} 
locação de serviços de transportes - foram os principais efeitos do PAA e, especialmente, do PNPB no município.

Isso pôde ser visível principalmente na área urbana de Morro do Chapéu quando a valorização "excessiva" do preço da mamona interrompeu a aquisição da produção da oleaginosa no local por parte da PBio. "Se a Petrobras deixa de comprar e operar esse contrato, o próprio comércio hoje já sente e os comerciantes falam que o grande problema para eles no momento é que a Coopaf deu uma parada no ritmo de produção que vinha tendo" (Fábio Pinto, 2011, STR-MC).

No entanto, a votação expressiva do candidato do grupo da cooperativa contribuiu para a eleição de dois vereadores da coligação encabeçada pelo então diretor presidente da cooperativa. Antonio Bento de Oliveira (PT), funcionário da agência local do Instituto Nacional de Seguridade Social (INSS), e Roberval Barberino Gonçalves (PCdoB), ex-presidente do STR-MC, foram os únicos vereadores eleitos no município com a proposta de fazer oposição ao grupo dominante. A análise de como se deu a espacialização da votação de ambos no município ${ }^{30}$, também expõe a diferença de atuação dos candidatos e, consequentemente, dos grupos ligados aos dois partidos políticos.

Enquanto $70,1 \%$ dos votos nominais a Antonio de Oliveira, que trabalhava na agência do INSS localizada na sede de Morro do Chapéu, foram realizados na área urbana do município, Roberval Gonçalves, obteve $51,1 \%$ dos votos nominais na sede e 48,9\% em seções eleitorais localizadas na zona rural. O equilíbrio da espacialização da votação de Roberval se dá, possivelmente, tanto pela atuação do sindicalista na sede do STR-MC, localizada na área urbana do município, quanto na zona rural.

A seção eleitoral na qual o vereador foi mais votado, a do povoado de Barras II (Tabela 3.3.1) - responsável por 13,3\% dos votos nominais a Roberval - está situada na localidade desenvolvida a partir de remanescentes quilombolas, que contribuíram para o PAA com o fornecimento de doces de marmelo (Zene Vieira, 2011, residência da entrevistada) e que mantinham relações com a Coopaf. O ex-presidente do STR-MC foi o vereador que obteve o maior volume de votos nominais na seção, com $30 \%$ dos votos válidos. Do mesmo modo, a seção de Barra II foi aquela em que Érico Sampaio recebeu a maior porcentagem dos votos nominais para prefeito no município: $75,4 \%$.

\footnotetext{
${ }^{30} \mathrm{~A}$ análise foi feita através da sistematização dos dados de votação por localização das seções eleitorais através dos espelhos dos boletins de urnas disponíveis no website do TSE (Tribunal Superior Eleitoral): $<$ http://www.tse.jus.br/eleicoes/eleicoes-anteriores/eleicoes-2008/consulta-ao-espelho-do-boletim-deurna-2008>. Acesso em: $10 \mathrm{dez} .2012$.
} 
Seçäo eleitoral 118 - Escola Municipal de Barra, Povoado de Barra 2, Morro do Chapéu (BA)

\begin{tabular}{|c|c|c|c|c|c|c|c|c|c|c|}
\hline \multicolumn{11}{|c|}{ Votaçäo para prefeito } \\
\hline $\begin{array}{l}\text { Virgílio } \\
\text { Ferraz }\end{array}$ & $\begin{array}{l}\text { Cleová } \\
\text { Barreto }\end{array}$ & $\begin{array}{l}\text { Wilson } \\
\text { Dourado }\end{array}$ & $\begin{array}{c}\text { Érico } \\
\text { Sampaio }\end{array}$ & Total & $\begin{array}{c}\text { Votos da } \\
\text { seçấo em } \\
\text { Érico }\end{array}$ & $\begin{array}{c}\text { Votos da } \\
\text { seçẫo em } \\
\text { Cleová }\end{array}$ & & & & \\
\hline 2 & 25 & 18 & 138 & 183 & $75,41 \%$ & $13,66 \%$ & & & & \\
\hline \multicolumn{11}{|c|}{ Votação para vereador } \\
\hline \multicolumn{3}{|c|}{ Total de votos nominais } & 164 & \multirow{3}{*}{\multicolumn{3}{|c|}{ Mais votados }} & \multirow{3}{*}{ Votos } & \multirow{3}{*}{$\begin{array}{c}\text { Votos } \\
\text { nominais na } \\
\text { seçẫo }\end{array}$} & \multirow{3}{*}{\begin{tabular}{|c|} 
Votos da \\
seção para o \\
total do \\
candidato
\end{tabular}} & \multirow{3}{*}{$\begin{array}{l}\text { Total de } \\
\text { votos do } \\
\text { candidato }\end{array}$} \\
\hline \multicolumn{3}{|c|}{ Total de votos de legenda } & 29 & & & & & & & \\
\hline \multicolumn{3}{|l|}{ Brancos } & 6 & & & & & & & \\
\hline \multirow{2}{*}{\multicolumn{3}{|c|}{$\begin{array}{l}\text { Nulos } \\
\text { Total apurado }\end{array}$}} & 18 & \multicolumn{3}{|c|}{ Roberval do Sindicato (PCdoB) } & 50 & $30,49 \%$ & $13,23 \%$ & 378 \\
\hline & & & 217 & \multicolumn{3}{|c|}{ Lucinha (PTC) } & 25 & $15,24 \%$ & $11,16 \%$ & 224 \\
\hline & & & & \multicolumn{3}{|c|}{ Toinho do PT (PT) } & 13 & $7,93 \%$ & $1,72 \%$ & 757 \\
\hline
\end{tabular}

Tabela 3.3.1 - Dados eleitorais do pleito de 2008 na seção localizada no povoado de Barra 2, em Morro do Chapéu. Fonte: TSE. Elaboração: Vinicius Morende.

O candidato do grupo ligado à Coopaf recebeu a maior porcentagem de votos nominais em outras duas seções eleitorais de outra localidade que forneceu farinha de mandioca para o PAA, a de Lagoa Nova (Tabelas 3.3.2 e 3.3.3). Nas mesmas seções, um dos candidatos a vereador pelo PCdoB, que atua no STR-MC e que não foi eleito no pleito de 2008, Ademar do Distoque ${ }^{31}$, também recebeu votações expressivas. O desempenho do candidato só não foi melhor do que o obtido na seção do povoado do Distoque (Tabela 3.3.4), no qual Ademar recebeu $62 \%$ dos votos nominais para vereador.

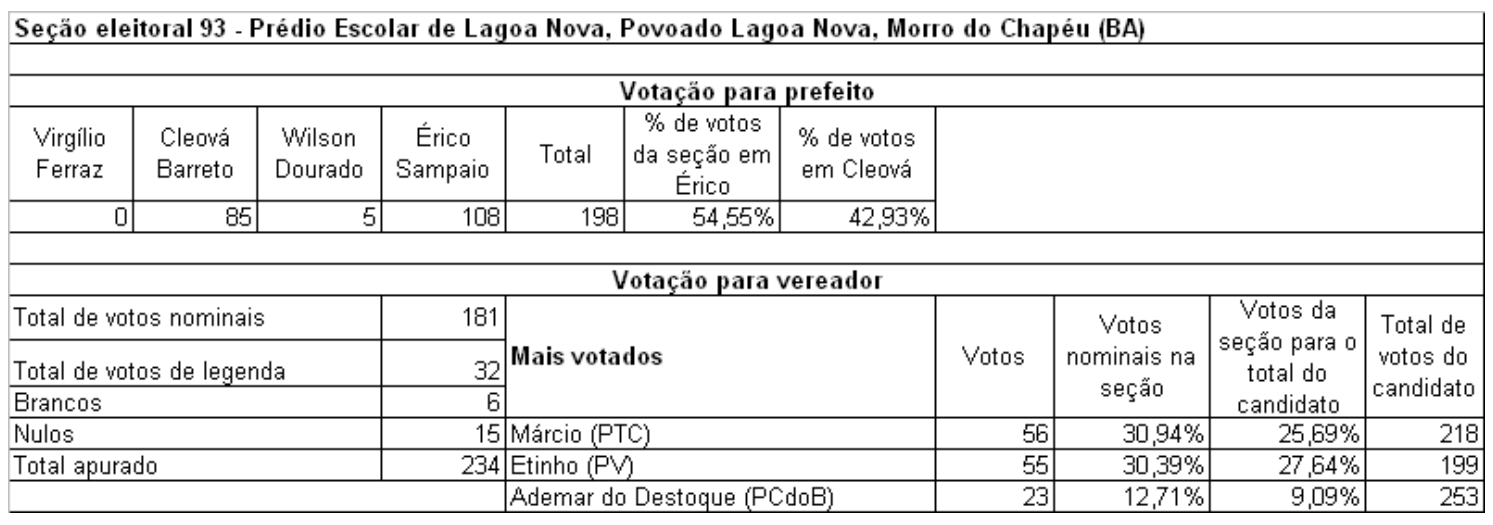

Tabela 3.3.2 - Dados eleitorais do pleito de 2008 na seção localizada no povoado de Lagoa Nova, em Morro do Chapéu. Fonte: TSE. Elaboração: Vinicius Morende.

\footnotetext{
${ }^{31}$ Nome do povoado localizado próximo ao de Lagoa Nova.
} 
Seçäo eleitoral 42 - Escola 15 de Novembro, Povoado Lagoa Nova, Morro do Chapéu (BA)

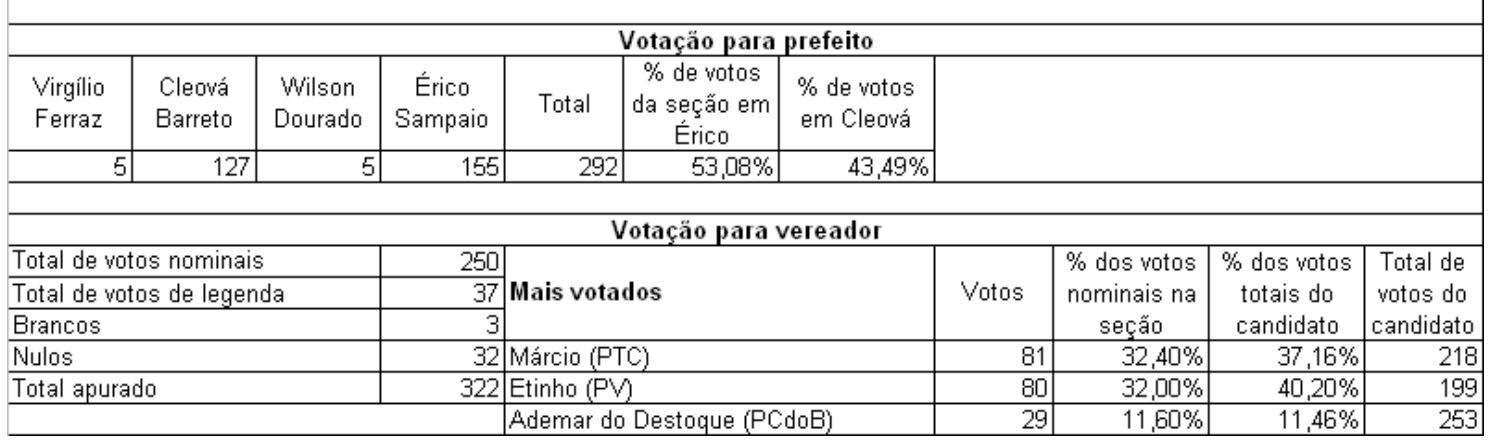

Tabela 3.3.3 - Dados eleitorais do pleito de 2008 na seção localizada no povoado de Lagoa Nova, em Morro do Chapéu. Fonte: TSE. Elaboração: Vinicius Morende.

Seçäo eleitoral 159 - Prédio Escolar Edmundo Reis Santos, Povoado do Destoque, Morro do Chapéu (BA)

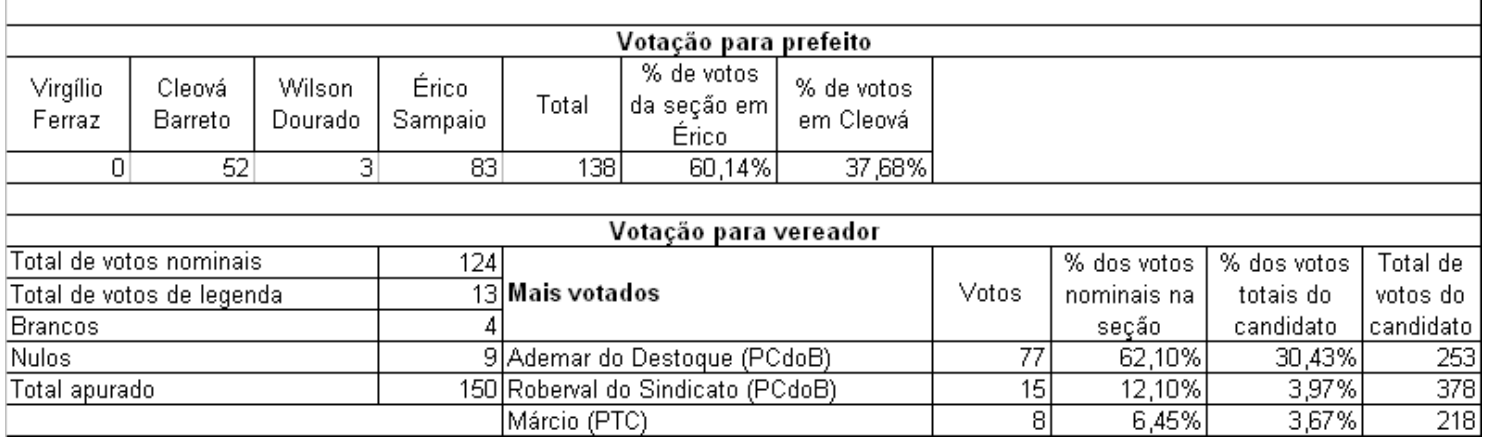

Tabela 3.3.4 - Dados eleitorais do pleito de 2008 na seção localizada no povoado do Destoque, em Morro do Chapéu. Fonte: TSE. Elaboração: Vinicius Morende.

É importante ressaltar também que as cinco seções nas quais o prefeito eleito Cleová Oliveira Barreto obteve os maiores índices percentuais de votação ${ }^{32}$ são aquelas localizadas nos limites territoriais do município, ou na localidade na qual o candidato possui propriedade (Tabela 3.3.5). Isso mostra a limitação da atuação operacional e, consequentemente, política do grupo ligado à cooperativa. Outra mostra da limitação da influência política deste grupo, é que em todas as seções eleitorais localizadas nos povoados de interesse deste trabalho, ou nas seções mais próximas a estes, o prefeito eleito teve a maioria dos votos válidos (Tabela 3.3.6). Em sete das onze seções consideradas o índice de votos válidos foi maior que o percentual de votação geral do prefeito eleito no município.

\footnotetext{
${ }^{32}$ As duas seções nas quais o prefeito eleito teve o maior percentual de votação se localizam num raio maior que 60 quilômetros da sede do município.
} 
Seçäo eleitoral 64 - Escola Municipal Elisa Maia de Oliveira, Povoado de Mulungu, Morro do Chapéu (BA)

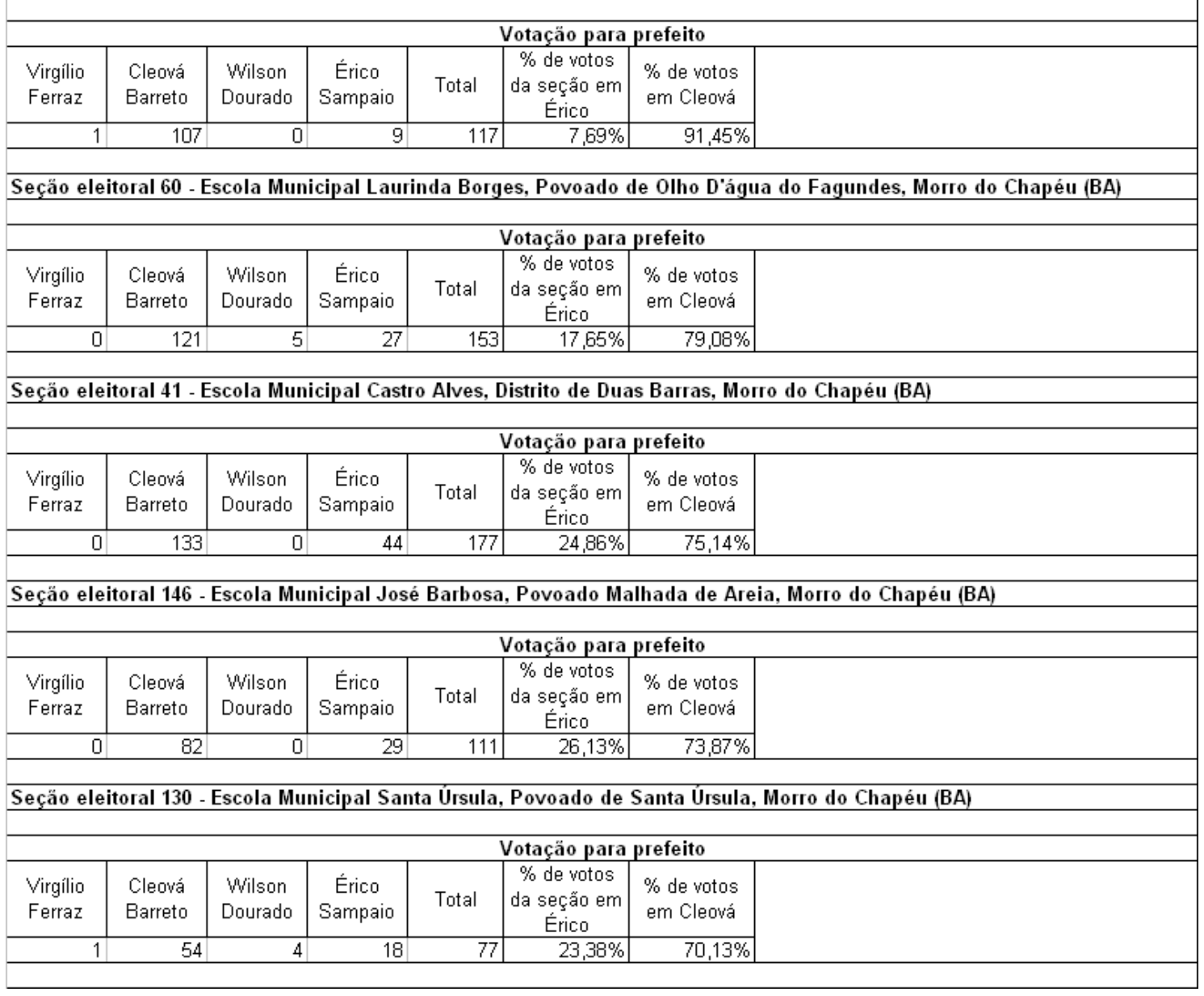

Tabela 3.3.5 - Dados eleitorais do pleito de 2008 nas seções em que o prefeito eleito de Morro do Chapéu obteve os maiores índices de votação. Fonte: TSE. Elaboração: Vinicius Morende.

Seçőes localizadas nos povoados de interesse da pesquisa ou nas proximidades

\begin{tabular}{|c|c|c|c|c|c|c|c|c|}
\hline \multicolumn{9}{|c|}{ Votaçäo para prefeito } \\
\hline $\begin{array}{l}\text { Seçẫo } \\
\text { eleitoral }\end{array}$ & Localidade & $\begin{array}{l}\text { Virgílio } \\
\text { Ferraz }\end{array}$ & $\begin{array}{l}\text { Cleová } \\
\text { Barreto }\end{array}$ & $\begin{array}{l}\text { Wilson } \\
\text { Dourado }\end{array}$ & $\begin{array}{c}\text { Érico } \\
\text { Sampaio }\end{array}$ & Total & $\begin{array}{c}\% \text { de votos } \\
\text { da seçẫo em } \\
\text { Érico }\end{array}$ & $\begin{array}{l}\text { \% de votos } \\
\text { em Cleová }\end{array}$ \\
\hline 146 & Malhada de Areia I & 0 & 82 & 0 & 29 & 111 & $26,13 \%$ & $73,87 \%$ \\
\hline 56 & Ouricuri I & 3 & 246 & 2 & 115 & 366 & $31,42 \%$ & $67,21 \%$ \\
\hline 48 & Fedegosos & 7 & 124 & 1 & 74 & 206 & $35,92 \%$ & $60,19 \%$ \\
\hline 51 & ICó & 5 & 119 & 1 & 74 & 199 & $37,19 \%$ & $59,80 \%$ \\
\hline 50 & Icó & 2 & 116 & 0 & 77 & 195 & $39,49 \%$ & $59,49 \%$ \\
\hline 132 & Fedegosos & 8 & 120 & 0 & 78 & 206 & $37,86 \%$ & $58,25 \%$ \\
\hline 157 & Fedegosos & 1 & 109 & 1 & 82 & 193 & $42,49 \%$ & $56,48 \%$ \\
\hline 47 & Fedegosos & 3 & 110 & 6 & 81 & 200 & $40,50 \%$ & $55,00 \%$ \\
\hline 127 & Brejônes & 3 & 98 & 0 & 84 & 185 & $45,41 \%$ & $52,97 \%$ \\
\hline 67 & Icó & 2 & 97 & 1 & 85 & 185 & $45,95 \%$ & $52,43 \%$ \\
\hline 76 & Icó & 3 & 102 & 0 & 90 & 195 & $46,15 \%$ & $52,31 \%$ \\
\hline 46 & Fedegosos & 4 & 116 & 5 & 104 & 229 & $45,41 \%$ & $50,66 \%$ \\
\hline
\end{tabular}

Tabela 3.3.6 - Dados eleitorais do pleito de 2008 nas seções de interesse da pesquisa em Morro do Chapéu. Fonte: TSE. Elaboração: Vinicius Morende. 
Alguns dos efeitos relacionados à "possibilidade de o espaço afetar o comportamento eleitoral, isto é, a decisão do eleitor diante da urna" (CASTRO, 2005, p. 161) podem ser considerados para fundamentar as conjeturas realizadas a respeito do processo eleitoral de 2008 em Morro do Chapéu. Entre eles está o efeito dos amigos e vizinhos "importante nos sistemas majoritários com distritos muito pequenos" (CASTRO, 2005, p. 161) e o efeito da vizinhança:

que explica por que os partidos obtém melhores resultados nas zonas em que são mais fortes em seus bastiões. Este efeito explica a concentração de determinado tipo de voto em áreas mais homogêneas, que são mais discerníveis em escalas menores - como bairros, comunidades rurais, municípios pequenos, nos quais há um segmento social dominante: classe trabalhadora, elite, etnia, religião etc. (CASTRO, 2005, p. 161).

Este efeito pode contribuir para explicar a expressiva votação nos vereadores e nas legendas da coligação formada pelos representantes do grupo ligado à Coopaf nas seções eleitorais das localidades de interesse deste trabalho, apesar da derrota do candidato do grupo à prefeitura nas mesmas seções. Em sete das onze seções consideradas neste caso, a soma dos votos nos candidatos e nas legendas deste grupo representou mais de $20 \%$ dos votos válidos (Tabela 3.3.7). O volume pode parecer tímido, mas significa uma representatividade inédita para os representantes do grupo. Vale ressaltar que o próprio Érico Sampaio, que não conseguiu se eleger vereador no pleito de 2004, obteve quase 7.000 votos em todo o município em 2008.

\begin{tabular}{|c|c|c|c|c|c|c|}
\hline \multicolumn{7}{|c|}{ Seçöes localizadas nos povoados de interesse da pesquisa ou nas proximidades } \\
\hline \multicolumn{7}{|c|}{ Votação para vereador } \\
\hline $\begin{array}{l}\text { Seção } \\
\text { eleitoral }\end{array}$ & Localidade & $\begin{array}{l}\text { Votos em } \\
\text { candidatos } \\
\text { do PCdoB }\end{array}$ & $\begin{array}{c}\text { Votos em } \\
\text { candidatos } \\
\text { do PT }\end{array}$ & $\begin{array}{l}\text { Total de } \\
\text { votos no } \\
\text { grupo }\end{array}$ & $\begin{array}{c}\text { Votos válidos } \\
\text { da seção }\end{array}$ & $\begin{array}{c}\text { Relaçã̃o de } \\
\text { votos no } \\
\text { grupo pelos } \\
\text { votos válidos }\end{array}$ \\
\hline 46 & Fedegosos & 49 & 12 & 61 & 251 & $24,30 \%$ \\
\hline 47 & Fedegosos & 26 & 7 & 33 & 214 & $15,42 \%$ \\
\hline 48 & Fedegosos & 38 & 7 & 45 & 218 & $20,64 \%$ \\
\hline 50 & Icó & 4 & 31 & 35 & 202 & $17,33 \%$ \\
\hline 51 & Icó & 14 & 28 & 42 & 204 & $20,59 \%$ \\
\hline 56 & \begin{tabular}{|l} 
Ouricuri \\
\end{tabular} & 18 & 11 & 29 & 376 & $7,71 \%$ \\
\hline 67 & Icó & 8 & 31 & 39 & 194 & $20,10 \%$ \\
\hline 76 & Icó & 2 & 30 & 32 & 205 & $15,61 \%$ \\
\hline 132 & Fedegosos & 39 & 6 & 45 & 219 & $20,55 \%$ \\
\hline 143 & $\begin{array}{l}\text { Malhada de } \\
\text { Areia }\end{array}$ & 19 & 24 & 43 & 143 & $30,07 \%$ \\
\hline 157 & Fedegosos & 46 & 1 & 47 & 204 & $23,04 \%$ \\
\hline
\end{tabular}

Tabela 3.3.7 - Dados eleitorais do pleito de 2008 para a Câmara de Vereadores de Morro do Chapéu nas seções de interesse da pesquisa. Fonte: TSE. Elaboração: Vinicius Morende. 
A polarização política definida na eleição municipal atinge o ápice no pleito de 2010. Na ocasião, a disputa na esfera local se dá entre políticos que disputam vagas na Assembléia estadual e na Câmara dos Deputados. Edson Pimenta, na época ainda no PCdoB, representante do grupo do Coopaf, é o deputado federal mais votado do pleito no município, com quase $38 \%$ dos votos válidos. José Carlos Leão de Araújo, na época no PDT, que tem a região como um dos principais colégios eleitorais, foi o segundo mais votado, com $35,3 \%$ dos votos válidos.

É possível que a intensificação dos fluxos regionais relacionados à cultura da mamona, com a entrada da PBio no mercado, assim como a intensificação dos fluxos financeiros concentrados na Coopaf tenham beneficiado o representante a deputado federal vinculado ao grupo político da cooperativa na escala local. O município foi o terceiro da Bahia no qual o deputado eleito conseguiu o maior percentual de votos válidos (Tabela 3.3.8). Edson Pimenta não obteve resultados tão significativos nos demais municípios da região nos quais a Coopaf operava.

\begin{tabular}{|c|c|c|c|}
\hline \multicolumn{4}{|c|}{ Municipios da Bahia nos quais Edson Pimenta recebeu os maiores índices de votação } \\
\hline \multicolumn{4}{|c|}{ Votação para deputado federal } \\
\hline Município & Votaçẫo Nominal & $\begin{array}{c}\text { Quantidade de votos } \\
\text { válidos }\end{array}$ & $\begin{array}{l}\text { Relaçẫo dos votos } \\
\text { válidos do candidato } \\
\text { pelo total no município }\end{array}$ \\
\hline RETIROLANNDIA & 3.416 & 7.564 & $45,16 \%$ \\
\hline IBICOARA & 3.000 & 7.857 & $38,18 \%$ \\
\hline MORRO DO CHAPÉU & 6.111 & 16.089 & $37,98 \%$ \\
\hline MIRANTE & 1.328 & 4.723 & $28,11 \%$ \\
\hline ITAGIBÁ & 2.178 & 7.866 & $27,68 \%$ \\
\hline
\end{tabular}

Tabela 3.3.8 - Dados eleitorais do pleito de 2010 para a Câmara de Deputados Federal nos municípios da Bahia nos quais o deputado eleito Edson Pimenta obteve a maior representatividade de votos. Fonte: TSE. Elaboração: Vinicius Morende.

Por outro lado, Morro do Chapéu foi o oitavo município no qual o deputado federal eleito pelo PDT José Carlos Araújo obteve o maior índice de votos válidos. A cidade de Bonito, emancipada de Morro do Chapéu, foi o terceiro local no qual o deputado obteve os maiores índices de votação - 45,2\% dos votos válidos locais.

Os deputados estaduais mais votados em Morro do Chapéu também pertenciam ao PCdoB e PDT, respectivamente. Jean Fabrício Falcão, que obteve quase 20\% dos votos válidos para o cargo no município, possuía alinhamento político tanto com Edson Pimenta quanto com o grupo ligado à Coopaf (Tabela 3.3.9). Três das quatro cidades 
onde Jean Fabrício foi mais votado no Estado coincidem com aquelas que Edson Pimenta obteve as maiores votações, entre elas, Morro do Chapéu.

\begin{tabular}{|c|c|c|c|}
\hline \multicolumn{4}{|c|}{ Municípios da Bahia nos quais Jean Fabrício recebeu os maiores índices de votação } \\
\hline \multicolumn{4}{|c|}{ Votação para deputado estadual } \\
\hline Município & Votação Nominal & $\begin{array}{c}\text { Quantidade de votos } \\
\text { válidos }\end{array}$ & $\begin{array}{l}\text { Relaçẫo dos votos } \\
\text { válidos do candidato } \\
\text { pelo total no município }\end{array}$ \\
\hline MIRANTE & 1.203 & 4.784 & $25,14 \%$ \\
\hline IBICOARA & 1.765 & 7.931 & $22,25 \%$ \\
\hline MORRO DO CHAPÉU & 3.047 & 16.080 & $18,94 \%$ \\
\hline TREMEDAL & 1.725 & 9.322 & $18,50 \%$ \\
\hline CARAÍBAS & 683 & 5.193 & $13,15 \%$ \\
\hline
\end{tabular}

Tabela 3.3.9 - Dados eleitorais do pleito de 2010 para a Assembléia Legislativa do Bahia nos municípios da Bahia nos quais o deputado eleito Jean Fabrício Falcão obteve a maior representatividade de votos. Fonte: TSE. Elaboração: Vinicius Morende.

As disputas que antecedem o pleito municipal de 2012 promovem uma fragmentação de ambos os grupos políticos locais que se destacaram nas duas eleições anteriores, o que dificulta ainda mais a análise relacionada aos efeitos do PNPB e do PAA $^{33}$ para a formação do poder local no período de maior interesse da pesquisa. Entre os antecedentes que ajudam a explicar a fragmentação está a desfiliação do deputado federal Edson Pimenta do quadro do PCdoB (SECRETARIADO ESTADUAL DO PCDOB, 2011), o afastamento da diretoria da Coopaf e de Erico Sampaio da presidência da cooperativa (OLIVEIRA, 2011) e a desfiliação deste do PCdoB.

Além disso, o vice-prefeito da gestão de Cleová Barreto, Pedro Nilson Maia Montenegro, do Partido Trabalhista Brasileiro (PTB), lança-se candidato à prefeitura no pleito de 2012. Mesmo filiado ao PT, Érico Sampaio é preterido para a disputa da eleição majoritária e o partido indica Antônio Dantas para a vaga de vice-prefeito da chapa de Pedro Nilson. O PCdoB lança candidatura própria do comerciante Ivan Rios, que não possui participação representativa na Coopaf e no STR-MC. Érico Sampaio apóia a candidatura de Leonardo Dourado, do Partido Progressista (PP), cujo sobrenome revela o parentesco com uma das famílias tradicionais da microrregião. O prefeito Cleová Barreto deixa o PR e filia-se ao recém-criado Partido Social Democrático (PSD), partido pelo qual é reeleito com uma vantagem de 20 votos sobre o candidato do $\mathrm{PP}^{34}$.

\footnotetext{
33 As atividades do PAA se encerraram em 2008, no entanto, é possível verificar em alguma medida os efeitos do programa nos anos seguintes, o que será abordado no próximo capítulo.

${ }^{34}$ As coligações de partidos políticos que disputam o pleito de 2012 são formadas da seguinte maneira: PTB e PT (Unidos Pela Mudança); PCdoB, PTC e PSB (Por Uma Morro do Chapéu Mais Justa); PSD,
} 
Além da pequena margem de votos favorável ao prefeito eleito - 0,1 ponto percentual de vantagem - o grupo político dominante teve o apoio formal relativamente reduzido na Câmara de Vereadores de Morro do Chapéu após a disputa. Em 2008, 78\% dos vereadores eleitos eram filiados aos partidos que representavam o grupo. Em 2012, o índice caiu para 69\%, considerando que o número de cadeiras na Câmara saltou de nove para 13 no período.

O único representante político eleito em 2012 que pode ser ligado aos efeitos dos programas públicos analisados nesta pesquisa, por conta do envolvimento profissional com o STR-MC, foi Ademar Ferreira Andrade, o Ademar do Distoque, vereador que substituiu Roberval Barberino na cadeira do $\mathrm{PCdoB}$ na Câmara. Roberval não se reelegeu. Assim como em 2008, as seções eleitorais nas quais o vereador eleito conseguiu os melhores resultados em 2012 foram aquelas próximas ao povoado do Distoque.

Assim, a análise da apuração de votos nos processos eleitorais avaliados torna evidente a influência, em menor ou maior medida, da atuação de organizações como a Coopaf ou o STR-MC e a valorização dos representantes deste grupo político pelo eleitorado local.

\subsection{Espaço e uso da informação na escala local}

É possível considerar que o cultivo da mamona em Morro do Chapéu a partir do PNPB envolveu a cultura em uma nova "forma de utilização e funcionamento do espaço" (SANTOS, 2008, p. 148), uma forma que tem como base "a ciência, a tecnologia e a informação" (SANTOS, 2008, p. 148). Tanto no campo quanto na cidade, as ações hegemônicas do meio técnico, científico e informacional se realizariam por meio "de objetos hegemônicos" (SANTOS, 2008, p. 148). No caso do PNPB, em Morro do Chapéu, a Coopaf pode ser considerada como um destes objetos, pelo menos no que diz respeito à agricultura familiar.

Ainda utilizando como exemplo o município baiano, o parâmetro "ciência" pode ser visualizado no desenvolvimento de novas espécies de sementes de mamona mais adaptadas ao clima semi-árido produzidas pela Embrapa para apoiar as atividades do

PRB, PDT, PMDB, PSL, PSC, PR, PV, PRP e PSDB (União, Trabalho e Desenvolvimento); e PP e DEM (Mudar para Renovar). 
PNPB. As novas técnicas de plantio fariam parte da substância tecnológica da nova fase da cultura a partir de 2007. O aspecto "informacional" poderia ser tanto compreendido como estando presente nas influências globais que levaram o Estado a criar o PNPB, quanto na organização da produção da cultura no local.

\footnotetext{
a informação tanto está presente nas coisas como é necessária à ação realizada sobre essas coisas. Os espaços assim requalificados atendem sobretudo a interesses dos atores hegemônicos da economia e da sociedade, e assim são incorporados plenamente às correntes de globalização (SANTOS, 2008, p. 148).
}

A partir daí é possível compreender que os atores envolvidos com o PNPB e o PAA em Morro do Chapéu também passaram a exercer certa hegemonia em algumas localidades a partir do início dos programas, em certa medida, por terem o Estado como principal parceiro. Além disso, as informações em nível global, especialmente aquelas relacionadas aos incentivos aos biocombustíveis, também passaram a influenciar diretamente o local, por meio do PNPB.

Por outro lado, a influência da informação sobre a escala local a partir de outros objetos-técnicos também apresenta questões importantes para a análise da formação política, do equilíbrio do poder em Morro do Chapéu a partir de 2007 e da evolução do meio técnico-científico-informacional. Entre estes objetos estão os veículos de comunicação do município, entre eles o jornal Correio do Sertão, publicação que "sempre teve um estreito relacionamento com as classes dominantes de Morro do Chapéu - em particular com o coronel Dias Coelho" (LOPES, 2006, p. 38-39).

Dados os custo de produção e as dificuldades de manutenção de um periódico do tipo, não é do perfil do Correio do Sertão realizar críticas às administrações públicas do município e das cidades vizinhas. Atualmente, o jornal funciona mais como um espaço de divulgação de eventos realizados pelas prefeituras e de informações sobre a vida social de Morro do Chapéu e da microrregião. A importância social do periódico, portanto, é limitada tendo em vista a restrição da periodicidade e tiragem atual e durante o período de maior interesse desta pesquisa. Além disso, desde a época de criação da publicação, “a imprensa pressupunha pessoas alfabetizadas” (CHAUÍ, 2006, p. 35), e, como fora visto, eram poucas as escolas existentes no município.

No período mais recente analisado, as rádios instaladas em Morro do Chapéu podem ser consideradas os meios de comunicação mais influentes. Compreendidos como formas de comunicação de massa, do ponto de vista de quem produz o conteúdo, 
ou seleciona as informações transmitidas, os aparelhos de rádio podem ser considerados "centros de poder econômico" e "centros de poder político ou de controle social e cultural" (CHAUÍ, 2006, p.44).

No caso da sede de Morro do Chapéu, há duas rádios em funcionamento, uma comunitária e outra, instalada no ano de 2008, pertencente a familiares do deputado federal José Carlos Leão de Araújo (RODRIGUES, 2011). Este veículo de comunicação foi alvo do conflito de maior repercussão entre os grupos políticos ligados à prefeitura da cidade e à Coopaf durante o período analisado. Para compreender o confronto é necessário entender a influência política no conteúdo transmitido pela emissora, comum no caso dos meios de comunicação no Brasil, que, geralmente, estão ligados direta ou indiretamente a representantes políticos. Em geral, na televisão e no rádio, “o conteúdo, a forma e o horário do programa já exprimem em seu próprio interior a imposição do patrocinador" (CHAUÍ, 2006, 45).

Findadas as eleições de 2010, militantes do grupo ligado à cooperativa se aglomeraram em frente à emissora para protestar contra supostos insultos direcionados aos eleitores do deputado concorrente Edson Pimenta. O acontecimento acabou na invasão da rádio por pessoas ligadas ao grupo do PCdoB e em violência contra os radialistas. De modo geral, tanto no rádio, quanto na televisão, "as notícias são apresentadas de maneira a impedir que o ouvinte e o espectador possam localizá-las no espaço e no tempo" (CHAUÍ, 2006, 45). Assim, "as diferenças geográficas e territoriais são ignoradas" (CHAUÍ, 2006, 45), o que provoca a desinformação e dificulta a contextualização dos eventos. É possível compreender que os invasores da rádio promoveram exatamente um protesto contra esta prática.

Ironicamente, alguns meses depois, os correligionários no município dos dois deputados federais citados se consternaram ao saber que ambos haviam deixado suas legendas e migrado para o mesmo partido político, o PSD. Isso possivelmente dificultou a identificação do eleitorado com aquele grupo ao qual oferecia apoio, o que pode justificar o resultado da eleição majoritária de Morro do Chapéu em 2012, uma das mais disputadas do país.

Da mesma forma, nem a alta qualidade do óleo da mamona, as perspectivas de desenvolvimento social a partir do fortalecimento da cadeia produtiva, ou as oportunidades econômicas para o sertão, nem o pressuposto social do programa do biodiesel, parecem convencer os veículos de comunicação dedicados ao setor de biocombustíveis a respeito dos benefícios do cultivo da mamona. Pelo contrário, uma 
intensa batalha se assemelha para desqualificar o uso da oleaginosa como combustível (FREITAS, 2011a, p. 38).

É possível compreender que os proprietários de veículos de comunicação do setor, interessados em atrair maiores volumes de recursos financeiros, não oferecem apoio às atividades desenvolvidas por entidades como a Coopaf. Atores como os sojicultores, que, em geral, antes da criação do PNPB, já possuíam um nível de organização da produção mais avançado que a agricultura familiar, movimentam muitos recursos financeiros e são clientes mais interessantes para o setor privado da comunicação. Além dos sojicultores terem interesse na destinação da cultura para a produção de biodiesel, pela lógica de mercado, atuam contra os concorrentes, no caso, os produtores de mamona e outras oleaginosas.

No caso do PNPB em Morro do Chapéu, parece que tanto o poder da sojicultura em escala estadual e nacional, quanto a indústria ricinoquímica, unidas à força do poder "conservador" local, influenciam a tendência de enfraquecimento do grupo político que chegou a se destacar.

É importante considerar que o grupo que ainda controla a prefeitura viu com preocupação a ascensão de outro grupo político financiado com recursos federais. No entanto, principalmente depois da interrupção do contrato que a Coopaf possuía com a PBio e da suspensão da comercialização de grandes volumes de mamona pelo grupo ligado à cooperativa, o grupo político dominante deixou de se preocupar tanto com o "risco mamona" e passou a investir na atração de novas funções para o território do município.

Mais à frente, verificar-se-á com mais detalhes quais foram os efeitos econômicos do PNPB e do PAA para a escala local. A análise traz implícitas referências aos micropoderes que agem durante o processo analisado sobre o território do município promovendo novas dinâmicas e contradições. 


\section{Formação territorial a partir de 2007}

Para apresentar as mudanças provocadas pelo Programa Nacional de Uso e Produção do Biodiesel (PNPB) e o Programa de Aquisição de Alimentos (PAA) para o espaço em Morro do Chapéu e que influenciaram a formação territorial do município, especialmente, a partir de 2007, é necessário considerar uma série de aspectos. Entre estes estão os de ordem econômica, que impuseram novas dinâmicas às formas de diversas áreas, à função destinada às terras de agricultores e à própria organização do território.

Em relação às formas espaciais, é possível verificar que as mudanças mais evidentes são aquelas relacionadas ao PNPB ocorridas na zona rural. Isso porque as áreas cultivadas com a mamona se expandiram no município a partir do início das discussões na esfera federal para a consolidação do programa. De acordo com os dados do Sistema IBGE de Recuperação Automática (Sidra-IBGE) enquanto a média de hectares plantados com mamona em Morro do Chapéu no período entre 1994 e 2002 antes da consolidação dos debates sobre a política nacional para o biodiesel - era de 2.780, entre 2003 e 2011 o mesmo índice saltou para 5.916 hectares.

A expansão das áreas cultivadas com a mamona representa também a regionalização da cultura em mais espaços dentro do "território contínuo" (SOUZA, 2011, p.93) que é Morro do Chapéu. Considerando que o município está inserido na principal área produtora de mamona do país é possível verificar que ao longo das décadas as áreas ocupadas pela cultura passaram por sucessivos movimentos de expansão e retração.

Mesmo a análise da produção da mamona no município entre 2007 e 2011, com base nos dados do Sidra-IBGE, expõe estes movimentos em Morro do Chapéu. A área plantada com mamona no município em 2007, por exemplo, foi o dobro da de 2008. No entanto, enquanto em 2007 a mamona representava $24,8 \%$ das áreas cultivadas com culturas temporárias no município, em 2008, o índice era de $43 \%$. O total de áreas cultivadas com culturas temporárias em 2008 foi menos de um terço da área de 2007 24.225 ante 6.990 hectares. Além disso, entre 2007 e 2011, áreas que não eram tradicionalmente cultivadas com a mamona passaram por movimentos de expansão da cultura. 
O período marcou também a transformação do camponês que cultivava a mamona de maneira autônoma em cooperado da Coopaf, o que trouxe melhores condições de negociação para os agricultores familiares, além de maior autonomia destes em relação aos atravessadores, que financiavam o plantio da cultura e se "apoderavam" das áreas cultivadas por agricultores. A partir da disputa de influência entre a cooperativa e os atravessadores é possível verificar movimentos de TDR, ou de “territorialização - desterritorialização - reterritorialização" (FERNANDES, 2005, p. 29) em Morro do Chapéu entre 2007 e 2012.

Estes movimentos "da agricultura camponesa", ou da agricultura familiar, também representaram alterações nas "paisagens", na “estrutura fundiária" e nas "relações sociais" (FERNANDES, 2005, p. 29) na esfera local. É possível compreender o período de fortalecimento da atuação da cooperativa como um processo de territorialização da influência dos cooperados e desterritorialização dos atravessadores, enquanto os movimentos de enfraquecimento da Coopaf representavam a reterritorialização dos intermediários nas localidades, mesmo que a influência exercida por estes, muitas vezes não tornava o agricultor tão dependente deste ator como ocorria antes da cooperativa, quando até o acesso às sementes de mamona era financiado pelo atravessador.

Obviamente, uma série de fatores ajuda a explicar os movimentos de expansão e retração da área ocupada pela mamona no município, entre eles os climáticos, a estrutura fundiária, os próprios aspectos espaciais - tanto físicos quanto sociais - de cada local, além dos fatores econômicos.

O aumento e a estabilização do preço da mamona após o início do PNPB pode ser considerado o principal aspecto econômico relacionado às dinâmicas territoriais promovidas pelo programa em Morro do Chapéu. De acordo com dados do Sidra-IBGE, a partir de 2003, o valor da saca de 60 quilos da mamona no município passa a se valorizar, tendência que se consolida a partir de 2007. Neste período, o valor da saca não atinge patamar inferior a $\mathrm{R} \$ 48$, mesmo quando a oferta do produto é alta por conta da produção elevada, como em 2007, quando mais de 70 mil sacas de mamona são produzidas em Morro do Chapéu. A média de preços da saca no município entre 1994 e 2002 foi de $\mathrm{R} \$ 21,8$.

Para o presidente do STR-MC, o aumento do valor da saca da mamona trouxe mais garantias ao agricultor, que passou a ampliar as áreas cultivadas com a mamona e apostar mais na cultura. “A saca de mamona saiu de um preço médio de R $\$ 28$, e hoje o 
preço mínimo estabelecido é de $\mathrm{R} \$ 60$, sessenta e poucos reais. Isso faz qualquer agricultor voltar a investir na mamona" (Fábio Pinto, 2011, STR-MC).

O preço da saca da mamona para o agricultor de Morro do Chapéu ultrapassa os valores médios da região e aqueles aferidos pelo Sidra-IBGE. Possivelmente, porque o valor adotado para a saca no contrato firmado pela Coopaf com a PBio era o preço de mercado, "adotado pela praça de Irecê" (Fábio Pinto, 2012, STR-MC), definido pela Empresa Baiana de Desenvolvimento Agrário (EBDA) e que variava dependendo de alguns aspectos ao longo do ano, como os de oferta e procura.

O diretor operacional da Coopaf, Fabrício Amorim, narra o histórico do preço da saca de mamona na região antes e depois do PNPB e o salto do valor do produto após a PBio entrar no mercado.

\begin{abstract}
A saca antes do programa do biodiesel custava $\mathrm{R} \$ 18$ a $\mathrm{R} \$ 20$ na região, uma saca de 60 quilos. Ou seja, o agricultor que produzisse uma média histórica, que a gente pode considerar, de 600 quilos por hectare, esta a média nacional, naquela época ele teria $\mathrm{R} \$ 200$ por hectare, o que não pagaria nem o custo de produção, a mão-de-obra. Então, não teria nem como aplicar algum instrumento a mais, uma tecnologia a mais pra poder aumentar a produtividade, a exemplo da adubação, correção de solo, alguma coisa. Depois do programa de biodiesel, a mamona já alcançou preço até além do que a gente considera ideal para manter o mercado equilibrado, tanto do lado de quem produz, quanto de quem está investindo, que é a Petrobras. Chegou a R\$ 120 agora em abril, maio de 2011 (Fabrício Amorim, 2011, residência do entrevistado).
\end{abstract}

O presidente do STR-MC também ressalta a importância da chegada da PBio, a representatividade da atuação de mais um ator disputando o mercado da mamona, anteriormente dominado por atravessadores que forneciam o produto para a indústria ricinoquímica, e o impacto para o valor da saca de sementes. "A partir do momento que você tem mais competitividade na compra, a tendência é que o produtor comece a ganhar mais" (Fábio Pinto, 2011, STR-MC).

Faça um comparativo. A saca de mamona saiu de um preço médio de $\mathrm{R} \$ 28$, e hoje o preço mínimo estabelecido é de $\mathrm{R} \$ 60$, sessenta e poucos reais. Isso faz qualquer agricultor voltar a investir na mamona. Mas ainda é preciso muito, a gente sabe disso. (Fábio Pinto, 2011, STR-MC)

O agricultor Rosemiro José da Silva, do Icó, confirma a variação nos preços da saca da mamona ao longo do ano de 2011 e relaciona a perda de valor às interrupções da comercialização por parte da PBio e das atividades da Coopaf. "O ano passado, a saca de mamona foi até $\mathrm{R} \$ 130$. R\$ 80, R\$ 90, R\$ 100 até R\$130. Esse ano, porque a 
firma (Coopaf) não comprou, ela voltou pra R\$ 70" (Rosemiro José da Silva, 2012, residência do entrevistado).

Com a variação no preço da saca da mamona é possível verificar uma maior disputa no poder sobre os territórios de cultivo pelos cooperados, a partir do apoio da Coopaf, e pelos atravessadores. Apesar do PNPB não exigir o compromisso de venda da produção à Coopaf por aqueles agricultores que receberam os incentivos do programa, a maior parte dos agricultores se sentia compromissada a repassar a produção para a Coopaf, o que fortalecia a atuação dos cooperados frente os intermediários. A única forma que estes negociantes encontraram de manter alguma influência sobre os territórios nos quais atuavam foi pressionando o valor da mamona para cima, o que também beneficiou os agricultores em geral, mesmo aqueles que não eram cooperados.

Esta estratégia permitiu que os atravessadores mantivessem suas atividades mesmo no período de domínio da influência dos cooperados sobre o controle das áreas de cultivo nas localidades analisadas. Quando as atividades da Coopaf entraram em decadência a partir da interrupção do contrato com a PBio, a principal parceira da cooperativa, os atravessadores passaram a retomar o controle sobre o financiamento e a comercialização da cultura da mamona e, sucessivamente, sobre os territórios de cultivo.

\subsection{Mudanças nas formas da zona rural}

Após o PNPB e a valorização da cultura, mais agricultores familiares passaram a apostar na mamona para tentar aumentar a renda originada no "jogo" 35 da roça. Nas áreas tradicionalmente produtoras de mamona de Morro do Chapéu, como a região do Velame e da Malhada de Areia esse processo se deu intensamente. Em alguns casos, a influência financeira, porém, provocou a mudança no uso da terra. Em localidades como o Icó isso se deu com a substituição de outras culturas tradicionais, como o sisal.

O Icó é uma das localidades de Morro do Chapéu nas quais a produção histórica de mamona não era representativa e que passou por movimentos de incremento da cultura. Rosemiro José da Silva abandonou a cultura do sisal e dedica o aumento da área

\footnotetext{
${ }^{35}$ De acordo com o agricultor João Medeiros da Silva, o trabalho na roça se assemelharia a um jogo: "A gente planta. Às vezes dá certo, outras não" (João Medeiros da Silva, 2012, propriedade rural do entrevistado).
} 
destinada à mamona na sua propriedade ao programa do biodiesel e à atuação da Coopaf. "Plantei mais mamona de cinco anos pra cá. E mais, eu passei a roçar mais com a mamona depois dessa firma (Coopaf). Foi quando nós tivemos um retorno de preço. Tivemos um preço melhor, recuperou e nos animou a plantar mamona" (Rosemiro José da Silva, 2012, residência do entrevistado). O abandono do sisal, cultura cuja produção era destinada aos atravessadores, e a dedicação à mamona na função de cooperado é um exemplo do processo de enfraquecimento que os intermediários experimentaram no Icó no período de fortalecimento das atividades da Coopaf.

A repercussão do aumento nos preços da saca da mamona também levou agricultores e produtores de áreas com histórico produtivo de atividades mais valorizadas, como a pecuária e o cultivo do feijão, ou mais elaboradas, como a farinha de mandioca, a ampliarem as áreas plantadas com a mamona. Foi o caso de Fedegosos $^{36}$.

Um dos principais incentivadores da cultura no povoado, o agricultor João Medeiros da Silva, a cada ano aumenta a área destinada à mamona e diminui o espaço de culturas como o feijão e a mandioca na propriedade de nove hectares que possui em Fedegosos. O pequeno produtor, que passou a cultivar a terra com o apoio de diaristas em 2010, depois de se aposentar, opina que a produtividade da cultura no povoado é favorecida pelo volume maior de chuvas em relação às outras áreas de cultivo em Morro do Chapéu.

\begin{abstract}
Olha, antes de a cooperativa incentivar o plantio de mamona por aqui, ninguém plantava aqui em Fedegosos. Eram contadas as pessoas que plantavam um bocadinho. Cresceu dali pra cá. [...] Era um bando [de gente que chegou a plantar]. Só que uns deixaram de plantar, mas ainda tem um monte que planta. [...] [Eu] plantava uns pouquinhos. [...] [Desde que a cooperativa começou a atuar] Daí pra cá eu aumentei" (João Medeiros da Silva, 2011, barbearia do entrevistado).
\end{abstract}

\footnotetext{
${ }^{36}$ Comparando as dinâmicas de expansão e retração da ocupação da mamona com aspectos físicos, em Morro do Chapéu, é possível considerar que a área tradicional de cultivo da mamona, a oeste, onde está localizado o povoado do Velame, e a área do Icó, possuem subclasses de capacidade de uso do solo semelhantes. Ambas são aptas "com restrições para culturas de ciclos curto e longo e pastagem plantada climaticamente adaptadas" e apresentam "fortes limitações climáticas com prolongados períodos de seca, e ligeiras por ocasional profundidade efetiva escassa" (ROCHA, COSTA, 1995b). Diferentemente de Fedegosos, que possui influência de uma subclasse de solo apta às mesmas atividades da área anterior, além de reflorestamento, com limitações distintas, sendo elas o "baixo nível de fertilidade natural", "irregularidade nas precipitações pluviométricas" e ligeiro "risco de erosão devido à declividade" (ROCHA, COSTA, 1995b). As áreas citadas estão sob influencia da classe de solo que representa 34,3\% da área de Morro do Chapéu. Outros 34,3\% do solo do município são áreas aptas para algumas culturas e atividades com restrições distintas. Por outro lado, $31,4 \%$ da área total do município apresentam severas limitações para a agricultura e pecuária, ou são de preservação permanente (ROCHA, COSTA, 1995b). Formam, principalmente, paisagens acidentadas ou rochosas, razão que pode justificar a ainda representativa extensão territorial de Morro do Chapéu em comparação à média dos municípios baianos.
} 
O sindicalista Fábio Pinto dedica ao PNPB a motivação que levou agricultores de Fedegosos a investirem mais na mamona. De acordo com ele, a pecuária e a produção de café ainda são as atividades mais expressivas da localidade, enquanto o feijão entrou em decadência nos últimos dez anos, o que provocou o afastamento de trabalhadores para outras áreas que passavam a produzir mais mamona. "Na época do feijão, há 10 anos, todo mundo saía destas regiões [mais áridas] para plantar feijão [em Fedegosos]. Agora, as pessoas estão saindo de Fedegosos para buscar uma área diferente de lá, para ajudar a plantar mamona, para trabalhar" (Fábio Pinto, 2011, STR$\mathrm{MC})$.

No povoado, outros afirmaram que as áreas plantadas com mamona e o número de pessoas trabalhando com a cultura aumentou com a atuação da Coopaf no município. Em algumas das roças pertencentes às famílias do grupo de mulheres de Fedegosos que forneceu o beiju para o PAA durante o ano de 2008 o cultivo da mamona já era realizado antes do PNPB, mas a área cultivada aumentou com a valorização da cultura.

A matriarca de uma destas famílias, a agricultora Maria Aparecida Leite Cardoso, a Nena, nascida em Mauriti, no Ceará, vive em Fedegosos há cerca de 40 anos. Ela se tornou a responsável pela propriedade de 20 tarefas da família no povoado após o falecimento do marido e cultiva diversas culturas, em especial a mandioca, com a ajuda dos três filhos ${ }^{37}$. A existência de uma casa de farinha comunitária no povoado e de pelo menos outras quatro casas do tipo próximas ou na localidade mostra a importância da mandioca para a região de Fedegosos.

Nena explicou que cultiva a mamona há muito tempo por ser uma cultura fácil de colher e que costuma vender a produção para o atravessador da cidade de Várzea Nova, o principal da região. Este município pode ser acessado por meio de uma estrada vicinal que liga Fedegosos ao povoado da Santa Mônica, localizado a poucos quilômetros da sede da cidade vizinha, ou pelo percurso rodoviário que liga a sede de Morro do Chapéu até Jacobina.

A agricultora confirma que o número de pessoas que plantam mamona próximo ao povoado aumentou nos últimos anos. "O povo se interessou mais a plantar roça. Tem muita gente plantando mamona, porque é um trabalho que não é obrigado a estar todo o

\footnotetext{
37 Dois dos filhos de Nena são casados e, além de ajudarem a mãe na propriedade da família, possuem outras "roças" próprias. Um deles havia sido assentado recentemente. O filho mais novo da agricultora é o que mais contribui para o cultivo na propriedade familiar.
} 
dia na roça. Ali capinou, no dia de quebrar, quebra e pronto. Deixa no terreiro e você só vai lá no dia de bater ${ }^{38}$ de novo" (Maria Aparecida Leite Cardoso, 2011, residência da entrevistada).

O pai de Simone dos Santos Souza - a interlocutora do grupo de mulheres fornecedoras de beiju para o PAA junto à Coopaf e, atualmente, merendeira de uma escola pública no povoado - também costumava cultivar pequenas áreas com mamona na propriedade de cinco tarefas que a família possui. Assim como outros produtores, o agricultor ampliou o espaço dedicado à cultura, "Meu pai mesmo plantou uma roça grande de mamona, mas está começando a produzir ainda. Ele já teve uma roça pequena. Agora ele tem uma maior" (Simone dos Santos Souza, 2011, residência da entrevistada).

No Velame e na Malhada de Areia, em Morro do Chapéu, os movimentos de plantação de mamona se intensificaram a partir da atuação da Coopaf e passaram a exercer pressão sobre a oferta de terras disponíveis para o cultivo. Os próprios cooperados expandiram suas áreas de cultivo sobre as áreas vizinhas, daqueles que eram autônomos e não podiam se enquadrar como fornecedores do PNPB, ou daqueles que simplesmente não se interessavam em cultivar a mamona ou outras culturas, mantendo as propriedades sem atividades. Isso se deu com mais intensidade a partir da entrada da PBio no mercado. O agricultor Jaílson Rosa Rodrigues, da Malhada de Areia, é um dos cooperados mais requisitados pela Coopaf quando há a necessidade de atender veículos de comunicação ou quando a visita de algum representante de organismos públicos surpreende os administradores do grupo.

O agricultor produz na propriedade de 30 tarefas do pai, que sofreu um acidente vascular cerebral e não possui mais condições de trabalhar, na Malhada de Areia, junto com irmãos e cunhados e se orgulha de dizer que mudou de vida por conta do PNPB, deixando a situação de miséria. Além da propriedade da família ter ficado quase completamente tomada com diversas variedades de mamona, entre elas as tradicionalmente cultivadas na localidade e outras fornecidas pela Coopaf, Jaílson também arrendou propriedades vizinhas para expandir as áreas com a cultura.

Estimulou tanto que o pequeno produtor que plantava duas, três tarefas (cerca de 1,5 hectares) hoje planta $30,40,50$. Você vê que toda esta área é plantada com mamona. E não é fácil fazer 50 tarefas de roça aqui, mas faz. Eu mesmo tenho 50 tarefas de mamona. [...] E eu só plantava às vezes cinco. Tinha ano que eu plantava 10 na sociedade e hoje por causa do projeto [do biodiesel] eu

\footnotetext{
${ }^{38}$ Termo relacionado ao beneficiamento manual de separação da casca, ou palha, do grão da mamona.
} 
faço 50 tarefas de mamona. E tenho minha independência (Jaílson Rosa Rodrigues, 2011, propriedade do entrevistado).

Com a elevação dos ganhos financeiros provenientes do cultivo da mamona o volume de áreas disponíveis para arrendamento na localidade também escasseou. Jaílson cita o caso de um proprietário de terras nas proximidades que se mostrou disposto a colocar certa área à disposição de arrendatários e aguçou o interesse de produtores. De acordo com o agricultor, houve propostas de interessados em arrendar lotes de 20, 50 tarefas e até a área toda. "Já está disputada no palitinho" (Jaílson Rosa Rodrigues, 2011, propriedade do entrevistado). O próprio Jaílson, além de outros agricultores da vizinhança, tinha interesse em arrendar parte desta área.

Não se acha mais área aqui, o cara tenta arrendar, não se arrenda mais. Já está tudo ocupado. [...] Não tem mais espaço pra nada nesta região nossa. Se você chegar e disser: "- Moço eu quero 20 tarefas de terra", você não acha. Esta daqui [vizinha] é de um amigo meu, vizinho, ela está toda arrendada. (Jaílson Rosa Rodrigues, 2011, propriedade do entrevistado).

Após a consolidação do PNPB e a intensificação da atuação da Coopaf outras mudanças nas formas de uso da terra na zona rural de Morro do Chapéu pareceram ser evidenciadas para quem costuma circular pelas estradas vicinais e caminhos que levam às propriedades rurais e aos núcleos populacionais do município. O presidente do STRMC, Fábio Pinto, reside na fazenda Boa Sorte, no povoado de Queimada Nova, próximo ao Velame, e afirma que foi possível verificar a recuperação de estabelecimentos rurais da localidade e de diversas outras no município e na região nos últimos anos. "Deixouse de vender tanta terra quanto estava se vendendo" (Fábio Pinto, 2011, STR-MC). De acordo com o sindicalista, muitas pessoas que não se dedicavam mais à agricultura passaram a recuperar as roças e cultivar a mamona por conta da valorização da cultura.

Muitas propriedades estavam abandonadas e hoje as atividades nestas
propriedades estão sendo retomadas. [...] Você passa numa estrada onde tinha
cerca caída de um lado, mato comendo do outro, casa abandonada do outro e
de repente você vê ali uma cerca arrumadinha, uma cerca nova, uma casa
recuperada, uma pastagem mais limpa. Onde era uma área praticamente
degradada, já em processo de desertificação, hoje você já vê uma cultura
implantada. Isso é visível. Quem passa hoje não vai perceber, mas para quem
passava há um tempo e passa hoje, aí é perceptível (Fábio Pinto, 2011, STR-
MC).

As mudanças nas formas espaciais citadas representam efeitos de ordem econômica promovidos, principalmente, pelo PNPB. No entanto, a questão climática no 
sertão baiano impôs restrições à produção da mamona no período de atuação do programa e também pode ter contribuído para a variação do valor de mercado da cultura. Mesmo considerando as grandes diferenças de precipitação entre as diversas localidades do município ${ }^{39}$ (ROCHA, COSTA, 1995c), no caso da mamona, a escassez de chuvas também pode ser a principal explicação para a redução da área plantada com a cultura entre 2008 e 2009 - de 3.000 para 1.000 hectares -, a perda da produção em 600 hectares neste ano, além do fato de 2010 ter sido o ano no qual se plantou a menor área com mamona no município na série histórica do Sidra-IBGE ${ }^{40}-250$ hectares.

A escassez do produto devido à estiagem influencia a dinâmica de oferta e procura e pode ter contribuído para os recordes nos valores da saca da mamona alcançados naquele ano e em $2011^{41}$, quando a mamona ocupou quase $70 \%$ das áreas cultivadas com culturas temporárias no município. O valor da saca da mamona em Morro do Chapéu no ano de 2010, de acordo com os dados do Sibra-IBGE, só não foi maior do que em 2003 e $2004^{42}$, período no qual os debates sobre o uso de variadas oleaginosas, entre elas a mamona, para o programa do biodiesel pode ter pressionado o preço da cultura ${ }^{43}$.

De acordo com Jaílson Rosa Rodrigues, da Malhada de Areia, em algumas épocas dos recentes períodos de comercialização da mamona, a disputa pelo produto e as formas de persuasão dos compradores se tornaram intensas. Houve agricultores que conseguiram comercializar sacas de mamona por valores entre R\$120 e R\$130 durante certa época de 2011. De acordo com Jaílson a mamona é plantada há mais de 100 anos na localidade da Malhada de Areia. "Meus avós já plantavam mamona” (Jaílson Rosa Rodrigues, 2011, propriedade do entrevistado). O agricultor afirma ainda que a única época em que o preço da mamona aumentou do mesmo modo como após o PNPB foi na década de 1980. "Não sei por quê. As áreas também eram poucas. Eram as nossas e as

\footnotetext{
${ }^{39}$ Disponível através da média histórica aferida por informações de postos pluviométricos e estações metereológicas situados em diversas localidades do município e instalados por diferentes órgãos públicos, entre eles o DNMET (Departamento Nacional de Metereologia), o DNOCS (Departamento Nacional de Obras Contra a Seca) e a Sudene.

${ }^{40}$ O levantamento de dados de Produção Agrícola Municipal do Sidra-IBGE está disponível a partir do ano de 1990 até 2011.

${ }^{41}$ Em 2011, a área plantada com mamona no município retomou o nível de 2008. De acordo com dados do Sidra-IBGE, naquele mesmo ano colheu-se a totalidade da área cultivada em Morro do Chapéu.

${ }^{42}$ O preço da saca em 2004 em Morro do Chapéu, de acordo com dados da Produção Agrícola Municipal do Sidra-IBGE, foi de R\$65,87, valor que reajustado pelo INPC (Índice Nacional de Preços ao Consumidor), do IBGE, equivaleria a R\$99,59 em novembro de 2012.

${ }^{43} \mathrm{O}$ período entre 2003 e 2006 marcou também os anos em que as maiores áreas com mamona foram cultivadas em Morro do Chapéu na série histórica do Sidra-IBGE. Dez mil hectares foram plantados com a cultura em cada um destes anos. A média de ocupação da mamona em relação ao total de culturas temporárias no município neste período foi de 37,5\%.
} 
do pessoal de Joaquim ali" (Jaílson Rosa Rodrigues, 2011, propriedade do entrevistado).

O preço da mamona é acima do que a gente esperava. Bem acima. Graças a Deus o preço da mamona deu de $\mathrm{R} \$ 130$ a saca no ano passado. Pena que a produção foi pouquíssima, porque nós só tivemos aqui 260 milímetros de chuva. E a mamona, para colher, nós precisamos de 500 a 600 milímetros/ano. E no ano passado pra esse ano a produção foi muito abaixo do esperado. Mas a gente já convive com isso. Um ano é acima da média, no outro ano é abaixo da média (Jaílson Rosa Rodrigues, 2011, propriedade do entrevistado).

Os valores pagos pela mamona, no entanto, também encareceram o óleo da cultura, utilizado para a produção do biodiesel. O custo financeiro representado pela utilização do óleo da mamona no composto adicionado ao combustível mineral, cuja variação possivelmente representou aumento de gastos para a PBio, que fornecia assistência técnica e financiava a compra da produção, é tido como um dos fatores que colocou em risco a utilização da mamona para o PNPB em detrimento de outras culturas menos nobres, portanto, menos valorizadas, como a soja. A expectativa do diretor operacional da Coopaf, Fabrício Amorim, era que os preços da saca da mamona se normalizassem num padrão que mantivessem a viabilidade da transformação da cultura em biocombustível.

Em alguns casos a gente viu [sacas] até de R\$ 125. Então é um preço que a gente vê que é totalmente fora da realidade do que a gente considera sustentável. Agora, hoje, 30 de junho a mamona está cerca de R\$90, ainda é um preço totalmente viável para o agricultor. E a gente acredita que deva se estabilizar entre R\$ 70 e $\mathrm{R} \$ 80$, que acho que é o preço mais razoável para ambos os lados, de quem está produzindo e comercializando, adquirindo esta produção, pra coisa se manter sustentável (Fabrício Amorim, 2011, residência do entrevistado).

O principal motivo da elevação no preço de mercado da mamona foi o PNPB e, principalmente, a atuação da PBio no setor. Mas isso não foi o suficiente para desarticular os atravessadores que seguiram comprando mamona pelo valor de mercado e atuando na região. "Ele (atravessador) acompanha o preço do biodiesel, em alguns momentos, até ultrapassa este preço" (Fábio Pinto, 2011, no STR-MC).

O sindicalista lembra que a fidelidade do fornecimento da mamona pelos agricultores não foi cobrada pela Coopaf, nem pela PBio. "Tem muita gente que recebe os incentivos do programa, como apoio técnico, a semente, alguma tecnologia, e repassa a produção, ou parte da produção, para o atravessador" (Fábio Pinto, 2011, no STR- 
$\mathrm{MC)}$. Isso ocorreu, principalmente, quando o preço pago por este superava aquele garantido pelo PNPB e pago pela cooperativa.

Quando a PBio interrompeu o contrato de comercialização que possuía com a Coopaf, entre 2010 e 2011, o gradual recuo nos preços da saca da mamona fez os agricultores refletirem sobre a situação de mercado à qual estava exposta a cultura.

Eu acredito que a mamona nunca foi desvalorizada. Mas sabe o que ocorre? Aqui na nossa região, no nosso sertão, quem compra é o atravessador, pra levar pro centro lá onde ela é destruída e tem bom preço. Então ele aqui aproveita porque sabe que não tem outro que compre, então o atravessador aqui compra pelo preço que ver. Olhe aqui, nós viemos ter esse preço de mamona aqui depois dessa firma (Coopaf) (Rosemiro José da Silva, 2012, residência do entrevistado).

O presidente do STR-MC explicou as dinâmicas comerciais da mamona na região. "Quando a Petrobras começa a comprar, o preço vai lá pra cima. Quando a Petrobras recua, eles têm um cartel e começam a jogar o preço da Petrobras pra baixo" (Fábio Pinto, 2011, no STR-MC). Em meados de 2011, com pouca produção, o estoque ainda não era tão elevado quanto viria a ser até o início de 2012. “O preço está baixo porque não tem outro comprador significativo, só têm eles (atravessadores) mesmos, então eles começam a jogar o preço pra baixo" (Fábio Pinto, 2011, no STR-MC). A influência dos atravessadores se manteve determinante para a variação no preço da cultura em Morro do Chapéu.

\subsection{Superação da perda da mamona nos terreiros}

É possível estabelecer uma série de considerações a respeito das variações no valor da saca da mamona relacionadas a fatores como a área plantada da cultura em Morro do Chapéu, a perda de áreas colhidas, a produtividade e fatores climáticos. Questões como a capacidade de absorção da produção agrícola pela indústria ricinoquímica, os valores de mercado pelos quais a PBio aceitaria adquirir o óleo e a capacidade de organização e de influência dos atravessadores, por outro lado, tornam mais complexa a análise. 
É possível fazer conjeturas sobre a problemática a partir dos relatos de alguns agricultores. Jaílson se lembra da época na qual a chuva e a boa safra não eram sinais de ganhos para o trabalhador.

\begin{abstract}
Nós perdíamos mamona no terreiro, no saco, porque não achava quem comprasse. E isso foi recente, em 1997. A gente plantava mamona, foi um ano chuvoso, a safra de mamona foi um absurdo e nós não achamos quem comprasse $^{44}$. Ficaram sacos naqueles meios de roça lá, do outro lado e passava 30, 40 dias os volumes de mamona na roça e ninguém nem queria roubar. Porque vai roubar pra vender a quem? Depois surgiu este incentivo da Petrobras, do biodiesel, daí veio o pessoal da BrasilEcodiesel comprando. Começou por aí. (Jaílson Rosa Rodrigues, 2011, propriedade do entrevistado).
\end{abstract}

$\mathrm{Na}$ época, os atravessadores eram os principais atores reguladores do preço da saca da mamona no local e a indústria ricinoquímica o único destino da produção. $\mathrm{O}$ ano de 1996 não havia sido produtivo para a cultura no município, quando foram colhidos 450 hectares dos 1500 plantados $-21,8 \%$ do total de culturas temporárias de Morro do Chapéu naquele ano. Em 1997, a área plantada e colhida expandiu-se para 6.000 hectares, o que fez aumentar a oferta do produto e derrubar o preço da mamona. Isso ocasionou a nova forma citada por Jaílson, temporária, em meio às propriedades rurais, representada pelo depósito de pilhas de sacas de mamona, inutilizadas pela falta de compradores.

O preço do produto subiu levemente em 1998, um acréscimo de $8,73 \%$, para $\mathrm{R} \$$ 50,45 em valores corrigidos pelo INPC. No entanto, a perda da produção em mais de $90 \%$ da área plantada ${ }^{45}$ neste ano fez o preço da saca da mamona voltar a disparar em 1999, para R\$ 96,33, em valores corrigidos pelo INPC, ano no qual, novamente, a área colhida foi menor que a metade da plantada ${ }^{46}$. O valor da cultura volta a cair entre 2000 e 2001 diante do baixo percentual de perdas em 3.500 hectares semeados com mamona em cada um destes anos.

De acordo com o presidente do STR-MC as incertezas em relação ao cultivo e aos ganhos com a mamona, ou seja, à função da cultura em satisfazer as necessidades

\footnotetext{
${ }^{44}$ No período entre 1990 e 2002 , o ano de 1997 foi aquele no qual se produziu mais mamona no município - 5.100 toneladas. Neste ano, a saca de mamona em Morro do Chapéu alcançou um dos menores valores da série histórica do Sidra-IBGE: R\$ 13,23. Reajustado para valores atuais pelo INPC o preço da saca equivaleria a $R \$ 46,40$. Naquele ano, a área plantada com mamona no município havia sido a maior desde 1990 - volume que só foi superado a partir de 2003 -, e a ocupação da cultura equivalia a $35,3 \%$ da área plantada com culturas temporárias no município.

${ }^{45}$ De 3.000 hectares plantados com mamona em 1998 no município, equivalente a 65\% da área total de culturas temporárias, apenas 200 hectares foram colhidos, de acordo com os dados do Sidra-IBGE.

${ }^{46}$ Apenas 600 hectares com mamona foram colhidos em Morro do Chapéu em 1999, de uma área plantada de 1.500 hectares ( $24 \%$ da área total destinada às culturas temporárias). Os dados são do SidraIBGE.
} 
do núcleo familiar, tornou a cultura menos atrativa para o agricultor familiar, até o início do PNPB.

Com o preço baixo, a falta de mercado e a baixa produtividade, $50 \%$ da mamona não estava mais sendo plantada no nosso município. Aí têm outros fatores intermediários como pragas. Mas, os principais eram estes. A falta de comercialização existia porque havia apenas uma empresa comprando a mamona de toda a microrregião e havia ainda a baixa produtividade. Isso fazia os preços ficarem lá embaixo. Produzindo pouco, não compensava cultivar a mamona. Com o programa do biodiesel, voltou-se a plantar mamona. Isso é o fator principal (Fábio Pinto, 2011, Sindicato dos Trabalhadores Rurais de Morro do Chapéu).

O agricultor José Barbosa de Jesus, o Zé Capoeira (Figura 4.2.1), foi um dos que investiu na cultura após o PNPB e a valorização da saca da mamona. José Barbosa ainda se lembra da caatinga encontrada na chegada ao povoado, na década de 1950, de Umburana, Quebra Facão, “de toda madeira boa” (José Barbosa de Jesus, 2011, propriedade do entrevistado). Naquela época, os trabalhadores eram responsáveis por queimar lotes de 20, 30, 40 tarefas e semear feijão, milho, mamona e mandioca. "Tudo o que queria podia plantar" (José Barbosa de Jesus, 2011, propriedade do entrevistado no Icó), dedicando ao dono da terra parte da renda obtida com a produção.

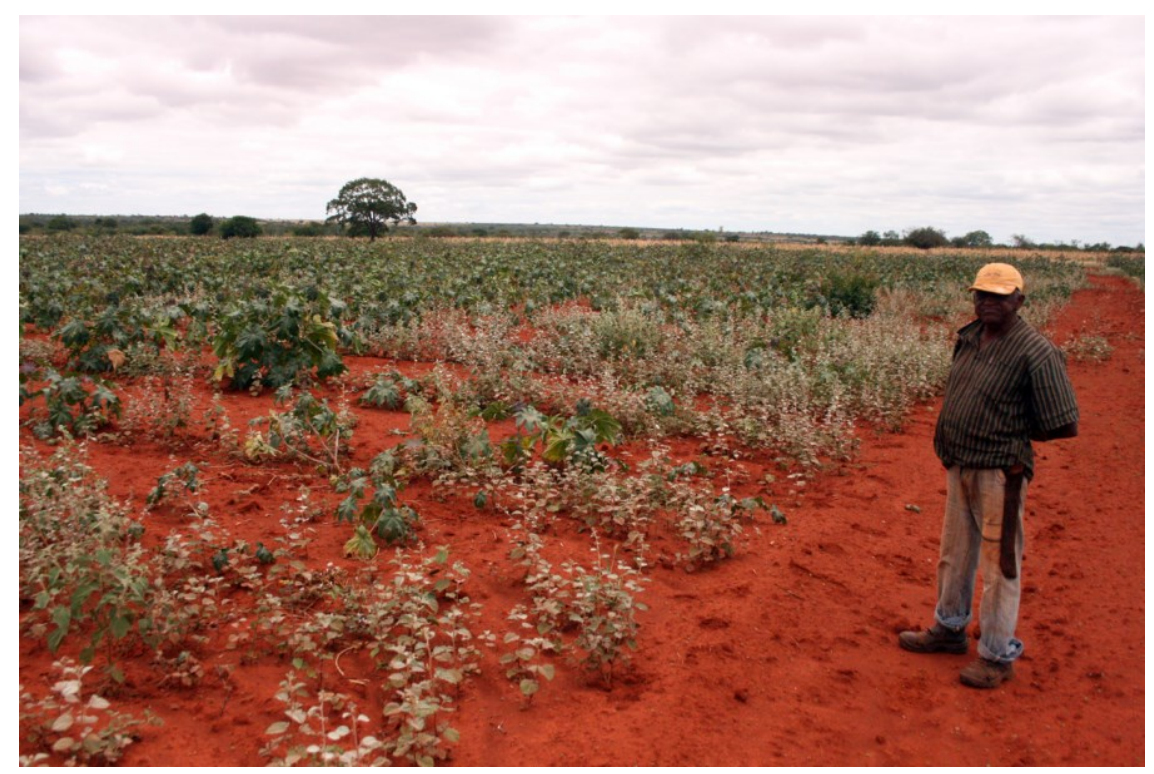

Figura 4.2.1 - José Barbosa de Jesus na lavoura de mamona plantada na propriedade da esposa, no Icó. Foto: Vinicius Morende, em 21/02/2012.

Atualmente, a propriedade de 16 hectares da família de Zé Capoeira está praticamente toda ocupada com a mamona. Outras áreas são destinadas ao cultivo do 
feijão e aos cuidados com as criações do agricultor. A área do criatório possui os objetos técnicos mais elaborados da propriedade, como casa para manter ferramentas, dois tanques para armazenamento de água e é limitada por uma cerca de Quiabenta ${ }^{47}$. José Barbosa se lembra da falta de interesse dos produtores em plantar a mamona por conta do baixo valor antes do programa do biodiesel.

O cara que plantava 20 tarefas, 10 tarefas, pegava e vendia uma roça dessa de
mamona por uma mixaria de dinheiro. O cara só comprava por aquele preço. E
todo dia ele baixava. E quando a cooperativa entrava não. O preço era aquele
legal, tranquilo, garantido e o povo danou de plantar mamona. Eles forneciam a
mamona para a gente plantar. Tinha tempo aqui que ninguém tinha um caroço
de mamona pra plantar. Tá, essa mamona aqui, a cooperativa forneceu para
todo mundo plantar aí (José Barbosa de Jesus, 2011, propriedade do
entrevistado).

Além do fornecimento de sementes adaptadas ao clima semi-árido, desenvolvidas e certificadas pela Embrapa, para os agricultores familiares de Morro do Chapéu e da região, contratos firmados entre a Coopaf e órgãos públicos e, posteriormente, entre a cooperativa e a PBio, previam, além da comercialização da produção, a assistência técnica rural aos produtores de mamona. A implantação de técnicas de plantio e o acompanhamento das etapas de cultivo por técnicos agrícolas familiarizados com as localidades produtoras podem ser sido os principais fatores para o aumento da produtividade da cultura no município a partir de 2007.

Foi a partir deste ano que, de acordo com os dados da série histórica do SidraIBGE para o município, a produtividade anual da mamona passou a ultrapassar a média histórica da região, que é de 600 quilos por hectare. Em 2008, a agricultura do município registra a maior produtividade da mesma série histórica, quando são produzidos 1.080 quilos de mamona por hectare colhido em Morro do Chapéu.

Mesmo a produtividade dos anos de 2009 e 2010 tendo sido abaixo da média histórica e este fato estar associado às perdas na produção e aos fatores climáticos, a média anual da produtividade no período entre 2007 e 2011 ainda é superior à média histórica da região ${ }^{48}$. Neste período de cinco anos foram produzidos 648 quilos por

\footnotetext{
47 Ou Jumbeba (PEIXOTO, 2002, p.192). A cerca, formada apenas pelos galhos espinhosos da planta impede a passagem de animais e pessoas e custa mais caro que o arame farpado e estacas. A forma costuma limitar áreas de criatórios ou casas na zona rural dentro do espaço maior da propriedade rural, esta sim, limitada com arame farpado.

${ }^{48}$ Sistematizando a comparação da média da produtividade da mamona no município em períodos de cinco anos, a produtividade obtida entre 2007 e 2011 só não é maior que as dos períodos entre $2004 \mathrm{e}$ 2008 e entre 2005 e 2009.
} 
hectare e o preço da mamona manteve-se elevado em relação ao padrão de negócios anterior ao PNPB.

Além de dedicar ao PNPB a retomada da produção da mamona em Morro do Chapéu e ressaltar a importância das novas tecnologias aplicadas para tanto, o presidente do STR-MC, Fábio Pinto afirma que foi o programa do biodiesel "que ensinou o produtor a plantar com o espaçamento correto, buscar novas variedades" (Fábio Pinto, 2011, STR-MC).

\footnotetext{
Hoje, três variedades que não eram produzidas aqui, a Energia, a Paraguaçu e a Pernambucana, são as principais produzidas no município. Muita coisa mudou no preparo do solo e tudo isso veio através do programa do biodiesel. Aliado a tudo isso o agricultor passa a conseguir melhor remuneração, a partir do momento que você tem mais competitividade na compra, a tendência é que o produtor comece a ganhar mais (Fábio Pinto, 2011, STR-MC).
}

Na maioria dos casos, a percepção de que a produtividade da lavoura de mamona aumentou é difícil de ser mensurada pelos agricultores familiares. João Medeiros, de Fedegosos, por exemplo, afirma que após receber a assistência técnica dos trabalhadores da Coopaf passou a produzir mais mamona. No entanto, a atual contagem de sacas por hectare - 10 sacas de 60 quilos por hectare seria o indicativo de alcance da média histórica - não era utilizada anteriormente, o que impede a comparação. "Eu não fazia aquele controle. Tinha vezes que eu estava batendo, tinha a precisão e vendia. Nunca tinha a base certa de quantas sacas eu batia do que havia plantado. Mas que [a produtividade] aumentou, aumentou" (João Medeiros da Silva, 2011, barbearia do entrevistado).

O aumento da concorrência no mercado da mamona por conta da atuação da PBio e a consequente variação nos preços da saca alterou também as práticas de comercialização dos agricultores familiares. Após o PNPB, estes deixaram de realizar várias quebras e vender a cultura em pequenas quantidades e passaram a acumular volumes à espera do melhor preço para, então, comercializarem a produção. Isso acontece, especialmente, com quem vende para os atravessadores.

Antes do PNPB a mamona era tida como a "feira do agricultor", isso porque os agricultores que tinham pequenas roças da cultura realizavam diversas quebras do produto ao longo da safra, comercializavam uma ou duas sacas e utilizavam o dinheiro para realizar as compras da semana nas feiras livres da região. 
Todo mundo ia para a feira, levava um, dois sacos de mamona pra voltar com a alimentação garantida. Hoje ela é tratada como negócio. Não é mais para fazer a feira. Hoje é o principal orçamento das famílias rurais que moram nesta região. Antes, a mamona ia produzindo e você ia vendendo, gastando, se mantendo. Hoje, ela é comercializada de uma vez. Há três quebras principais da mamona, uma ali no meio [da safra] e duas mais pro final. Hoje as pessoas estão guardando a produção para entregar de uma vez. Isso quem vende para o atravessador (Fábio Pinto, 2011, no STR-MC).

A necessidade de repassar a mamona para garantir a alimentação da semana levava os agricultores a ficarem até mesmo sem volumes para semear a propriedade na época do plantio. Com a distribuição de sementes pela Coopaf e, posteriormente, por outras cooperativas, o problema foi temporariamente remediado.

Porque ninguém tinha [sementes]. E na hora que você batia uma mamona, você vendia. Quando tirava um pouquinho, não dava pra nada e a cooperativa (Coopaf) deu umas mamonas selecionadas para o povo aí. Então hoje, todo mundo tem sua rocinha de mamona e a cooperativa aí (José Barbosa de Jesus, 2011, propriedade do entrevistado).

Luciano Bernardo de Brito, do Velame, que, como fora visto anteriormente, quando era criança, colhia a mamona e trocava um quilo de sementes por duas balinhas, compara a valorização que a cultura teve, principalmente, a partir de 2007, e a diferença representada para a renda do agricultor. "Hoje um quilo de mamona está cotado a R\$ 1,50. Você compra sete pãezinhos" (Luciano Bernardo de Brito, 2011, propriedade do entrevistado).

Após passarem por experiências como a de 1997, quando sobrou mamona nas roças, e sem qualquer informação prévia sobre a variação de preços da cultura, os agricultores se acostumaram a vender o produto independente do valor obtido. "Cabia era trocar com os caras (atravessadores) de qualquer jeito" (Jaílson Rosa Rodrigues, 2011, propriedade do entrevistado).

Depois do PNPB, além de adotarem práticas distintas de comercialização, os agricultores também passaram a armazenar a colheita da mamona, como João Medeiros da Silva, de Fedegosos. O agricultor passou pelo menos sete meses no ano de 2011 "apurando" os "caroços" (João Medeiros da Silva, 2011, barbearia do entrevistado) de mamona à espera da melhor cotação.

Da mesma forma, as sete sacas de mamona colhidas na propriedade de Maria Aparecida, a Nena, no mesmo povoado, durante o ano de 2011 não haviam sido comercializadas até o final do mês de fevereiro do ano seguinte. Nesta época, com o 
valor da saca a R\$90, Nena pretendia solicitar a um dos filhos para levar os volumes e vendê-los ao principal atravessador da região, situado no município vizinho de Várzea Nova (Maria Aparecida Leite Cardoso, 2012, residência da entrevistada).

Vale ressaltar que o novo padrão de armazenagem e comercialização manteve-se enquanto a Coopaf deixou de comercializar a produção, por conta da interrupção no contrato com a PBio, e é válido para o comércio realizado com os atravessadores. Durante o período em que a cooperativa realizou a compra da produção de mamona da agricultura familiar em Morro do Chapéu e na região - até o segundo semestre de 2010, quando a PBio teria deixado de adquirir a mamona da Coopaf (Jaílson Rosa Rodrigues, 2012, residência do entrevistado) -, o volume negociado exigiu que parcerias fossem estabelecidas em algumas oportunidades, a exemplo da associação comunitária da Malhada de Areia, para o armazenamento temporário de parte da produção.

Neste exemplo, citado como um "caso bem isolado" pelo presidente do STRMC, Fábio Pinto, a cooperativa teria contribuído com a recuperação dos armazéns da associação (Figura 4.2.2), localizados em frente à propriedade da família de Jaílson Rosa Rodrigues. "Em troca utilizou [os armazéns] por um período" (Fábio Pinto, 2012, STR-MC). De acordo com Jaílson Rosa Rodrigues, com os armazéns, a comunidade da Malhada de Areia tem a possibilidade de estocar e vender volumes de até 150 toneladas de mamona.

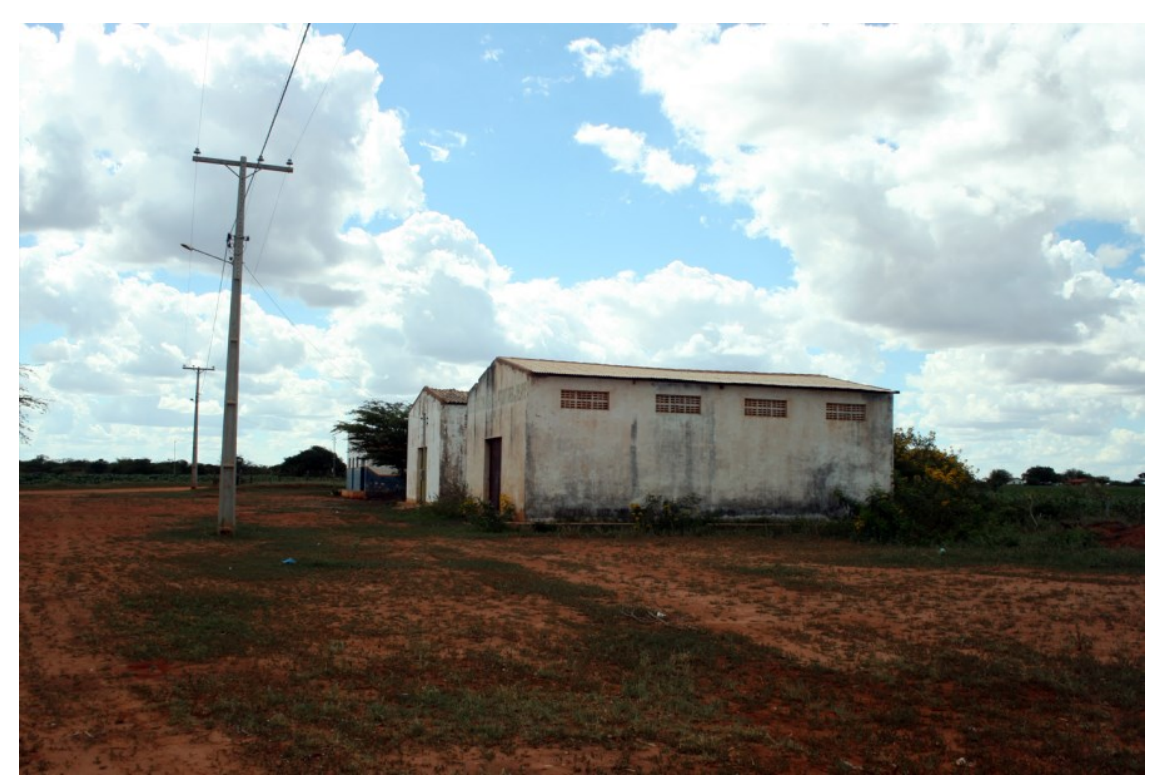

Figura 4.2.2 - Armazéns comunitários da associação de moradores da Malhada de Areia reformados com apoio da Coopaf e utilizados para armazenar a mamona destinada ao PNPB produzida na localidade e nas localidades próximas. Foto: Vinicius Morende, em 27/02/2012. 
No entanto, o presidente do STR-MC pondera que, no geral, o agricultor familiar ainda não possui capacidade financeira, de infra-estrutura, de logística, nem cultural para estocar mamona e alterar o cenário de mercado no qual a cultura está inserida. Apesar de afirmar que a mamona está se tornando o principal produto de algumas áreas do município, enquanto anteriormente desempenhava um papel "secundário e complementar", o sindicalista afirma que o agricultor ainda depende dos atravessadores, que estão "financiando a cultura da mamona" (Fábio Pinto, 2012, no STR-MC). Fábio Pinto ressalta ainda a falta de financiamento bancário destinado à cultura como fator prejudicial à capacidade da agricultura familiar de influenciar os preços praticados pelo mercado.

Considerando a variedade de fatores que influenciam os valores da mamona no longo prazo, é possível afirmar que no início de 2012 os atravessadores tinham a vantagem do estoque para barganhar o preço cobrado à indústria. Fábio Pinto analisa a situação.

\footnotetext{
Precisa entender que o atravessador tem estoque. Com o preço de estoque caro, no preço de R $\$ 70$ ele não consegue passar. Porque quando o preço estava de R\$ 130 e eles continuaram comprando e estocando, a indústria não absorveu neste preço e ele acabou ficando com o produto estocado. E ele agora não pode passar porque como eu compro por $\mathrm{R} \$ 120, \mathrm{R} \$ 110, \mathrm{R} \$ 90$ e vou passar por $\mathrm{R} \$$ 70 ? Então o estoque existe, está aí. Eu acredito que na mão dos atravessadores tenha mais estoque do que na mão das indústrias. [...] Quem tem as cartas na manga é quem tem o produto. E quem tem o produto são eles. Então, ou hoje, ou amanhã, a indústria vai precisar deste produto. Então, quem consegue vai segurar (Fábio Pinto, 2012, no STR-MC).
}

Mais difícil seria tentar refletir sobre o destino das variações dos preços pagos ao produto da agricultura familiar que acumula, além destas, outras variáveis conforme fora visto.

\subsection{Interrupção de contrato e declínio de preços}

Da mesma forma que o PNPB gerou expectativas em relação ao aumento da renda de milhares de famílias no sertão baiano também trouxe incertezas conforme alguns fatores se consolidaram. $\mathrm{O}$ alto custo do óleo de mamona para aproveitamento no programa do biodiesel e os boatos de que a PBio estaria revendendo o óleo produzido para a indústria ricinoquímica, são aspectos que preocuparam os próprios 
agricultores. A interrupção do contrato de comercialização da PBio com a Coopaf, a interrupção na compra da produção da agricultura familiar pela cooperativa, a escassez de chuvas, os atrasos nos salários dos técnicos e trabalhadores da cooperativa, entre outros fatores colocaram em dúvida as previsões de sucesso da iniciativa.

Embora a Coopaf não tenha negociado mamona nas safras anteriores, o que fez o preço da saca do produto cair, até 2012 os agricultores continuavam vendendo a produção para os atravessadores a preços superiores àqueles praticados antes do PNPB. Mesmo assim, fatores como o avanço do agronegócio e da soja no oeste da Bahia e a possibilidade do grão e dos empresários dominarem completamente o fornecimento de óleo para o mercado de biocombustíveis, põem mais incertezas nas perspectivas da agricultura familiar.

Entre os visitantes interessados em saber mais sobre o PNPB que Jaílson, da Malhada de Areia, cooperado da Coopaf, já recebeu na propriedade da família estão executivos da PBio. De acordo com o agricultor, autodenominado um otimista em relação ao futuro do programa do biodiesel, os próprios representantes da empresa já demonstraram preocupações em relação ao aumento dos custos para a produção do óleo de mamona.

\footnotetext{
Neste ano a gente (Coopaf) não comprou mamona. A PBio, a Petrobras, não comprou mamona devido ao preço alto. A mamona foi de R \$ 120 e tantos. E segundo eles é complicado comprar porque como é que vai fazer biodiesel a este preço. Para nós o medo do preço estar alto é amanhã a Petrobras parar de comprar e nós voltarmos para as garras do atravessador de novo. Não pode nem pensar, não vamos falar nisso não. [...] $\mathrm{O}$ [programa do] biodiesel não pode nem falar em acabar. Se falarem isso nós não dormimos, porque aí nós perdemos toda a nossa expectativa. (Jaílson Rosa Rodrigues, 2011, propriedade do entrevistado na Malhada de Areia)
}

Sem a participação da PBio, representada pela atuação da Coopaf, os atravessadores voltaram a ser os atores hegemônicos para a definição dos preços da mamona no mercado local. Num curto período o valor da saca da mamona variou de $\mathrm{R} \$$ 130 para R\$ 70. Os agricultores foram os principais prejudicados pela interrupção da comercialização pela PBio e a desvalorização da cultura no campo, já que os custos de produção da mamona não diminuíram no mesmo período (Rosemiro José da Silva, 2012, residência do entrevistado), pelo contrário.

Outro efeito provocado pelos incentivos à produção de mamona por meio do PNPB em Morro do Chapéu foi a criação de novas cooperativas de comercialização na região e na sede do município. Pelo menos outras duas se instalaram recentemente na 
cidade. Nenhuma delas, até o momento, conseguiu atingir o nível de influência da Coopaf, tampouco ganharam a confiança de agricultores para a intermediação da comercialização da mamona.

Rosemiro, do Icó, afirma ter sido procurado por uma destas organizações que sugeriu que ele "desistisse" da Coopaf e se cadastrasse "na Petrobras" (Rosemiro José da Silva, 2012, residência do entrevistado). "Eu disse não. Eu fico onde estou. Eu comecei lá, eu fico lá" (Rosemiro José da Silva, 2012, residência do entrevistado). Já Zé Capoeira, do mesmo povoado, afirmou que uma destas novas cooperativas distribuiu sementes de mamona na localidade. Na lógica do agricultor, "na hora que entrarem comprando as duas cooperativas de uma vez (Coopaf e a outra recém-criada), uma compra, a outra compra, aí segura o preço da mamona" (José Barbosa de Jesus, 2012, propriedade do entrevistado no Icó).

Antes da interrupção de contrato com a PBio a Coopaf havia passado a investir em outros empreendimentos. Entre eles, a fundação, em 2008, de uma organização para fornecer crédito aos agricultores, a Cooperativa de Crédito Rural da Agricultura Familiar (Creditag), também sediada em Morro do Chapéu. Um galpão numa das saídas da cidade passou a ser utilizado para a estocagem de produtos. A cooperativa ainda construiu um laticínio numa propriedade rural próxima à sede de Morro do Chapéu, iniciativa que tinha como objetivo produzir derivados do leite para atender o PNAE e abastecer o comércio regional. No entanto, em meio aos problemas administrativos que a Coopaf enfrentou, o laticínio foi desativado.

É possível estabelecer relações entre a limitação da atuação das atividades vinculadas à Coopaf, inclusive a interrupção do contrato com a PBio, e os problemas administrativos enfrentados pela cooperativa. Zé Capoeira relaciona a interrupção na comercialização da mamona aos problemas da Coopaf. "O povo andou reclamando muito, que teve umas fraudes na cooperativa. Mas quando foi de agosto, de setembro pra cá, teve uma eleição lá e nomeou outro presidente" (José Barbosa de Jesus, 2012, propriedade do entrevistado no Icó).

A assembleia para a votação das contas da Coopaf do ano de 2010, realizada em junho de 2011, havia definido o afastamento da diretoria e eleito uma nova diretoria constituída pelo ex-diretor de agricultura da EBDA, Luiz Bacelar Barata, na presidência, o engenheiro agrônomo, Fabrício Amorim, na direção operacional, Leandro Martins, na direção financeira, e Fábio Pinto, do STR-MC, como conselheiro de administração (OLIVEIRA, 2011, p. 4). 
Para o agricultor Jaílson Rosa Rodrigues, da Malhada de Areia, a movimentação de grandes volumes financeiros, a hesitação de pessoas ligadas à administração da cooperativa e o envolvimento político-partidário de integrantes da Coopaf estavam relacionados aos problemas da organização.

\begin{abstract}
Meteram política. Uma das coisas que a gente vai sentar com o presidente, com Barata, é: não queremos política [partidária]. Nem de um lado nem do outro. Porque o associativismo, o cooperativismo não depende de religião, facção política. É todos falando a mesma língua, o mesmo intuito. Buscar caminhar no mesmo sentido e não um para um lado e outro para outro (Jaílson Rosa Rodrigues, 2012, residência do entrevistado).
\end{abstract}

O agricultor está dentro da parte cooperados que não passou a apoiar o grupo político ligado à Coopaf após o início da atuação da cooperativa. Isso porque Jaílson já tinha apoio definido a outro político e não teve a opinião alterada pelo período de sucesso da organização. Ainda de acordo com ele, os próprios agricultores não estavam preparados para tomar o controle da situação e haviam errado em não se organizarem para se informarem sobre os detalhes administrativos da Coopaf.

A solução para não passarem pelo mesmo problema no futuro estaria no acesso à informação. "Agora nós temos carta branca pra falar direto com o presidente da Petrobras [Biocombustíveis] para saber onde está investimento, o que a cooperativa está recebendo. Não precisaremos ir na Coopaf para saber essas informações” (Jaílson Rosa Rodrigues, 2012, residência do entrevistado).

O sentimento de perda dos agricultores pela ausência dos técnicos agrícolas orientando a produção nas roças foi precedido pela desmotivação destes (Jaílson Rosa Rodrigues, 2012, residência do entrevistado na Malhada de Areia). Rosemiro do Icó questionava-se sobre a falta do técnico agrícola da Coopaf responsável pela localidade. "Mas dai ${ }^{49}$ pra cá eu nunca mais vi Fabrício [Falcão], que é sempre quem orienta nós aqui. Vai lá na roça, quer me ver, renovar meu cadastro. Olhar a situação de minha roça” (Rosemiro José da Silva, 2012, residência do entrevistado).

João Medeiros da Silva, de Fedegosos, que cultiva a mamona há doze anos, perdeu parte de uma roça de mamona em 2011 e em outros anos por conta de doenças que ele, sem assistência, não soube tratar. "Essa daí eu não quebrei quase nada, ela deu uma doença e aí quando ela veio começar a soltar o cacho foi do mês de agosto em diante. Aí pegou um tempo quente e pronto, não deu” (João Medeiros da Silva, 2011,

\footnotetext{
${ }^{49}$ Desde que recebera a visita do representante de outra cooperativa de comercialização do município.
} 
barbearia do entrevistado). As dez sacas produzidas numa área de algumas tarefas só não haviam lhe rendido prejuízo porque teve "muita gente aí que vendeu de R\$ 60 [a saca]. Era batendo e vendendo em bocadinho. Aí eu bati, fui ajuntando, quando ela acabou, eu vendi, estava de R\$ 80" (João Medeiros da Silva, 2011, barbearia do entrevistado).

Mesmo assim, de acordo com o agricultor, o aumento da renda a partir da mamona representa um recurso que dificilmente seria obtido da mesma forma por meio de outra cultura. "Quem plantou em quantidade, melhorou mais um pouco. Mas não são todos que ficaram plantando. Porque a mamona você planta, mas se ela não tiver a assistência certa ela morre. Muitos não querem mais plantar” (João Medeiros da Silva, 2011, barbearia do entrevistado).

É possível considerar que a falta de preparo tanto dos agricultores familiares para participarem ativamente das decisões dentro do esquema cooperativista, quanto dos administradores da Coopaf em gerir a iniciativa adequadamente foi determinante para o período de retrocesso das atividades da cooperativa. Ao mesmo tempo, a Coopaf também é fruto das articulações desenvolvidas pelo PNPB através da figura do governo federal, que falhou em acompanhar de perto iniciativas como a de Morro do Chapéu e prestar o devido apoio à consolidação da cooperativa. A conseqüência é a fragilização da situação do agricultor familiar que, sem assistência técnica, vê a produção de mamona ser prejudicada.

\subsection{Programa de Aquisição de Alimentos e alteração nos preços dos alimentos}

Além da mamona, o leite e o café são considerados os produtos agropecuários mais influentes em Morro do Chapéu atualmente. Há localidades cafeicultoras no município e o leite é considerado um produto de primeira necessidade. "O agricultor familiar tem por característica a diversidade, então, todo mundo tem uma vaquinha em casa" (Fábio Pinto, 2011, no STR-MC). Há ainda outra série de gêneros alimentícios produzidos na zona rural do município.

Foi apoiada na diversidade agrícola de Morro do Chapéu que a Coopaf passou a adquirir parte da produção e destiná-la às famílias beneficiadas pelo PAA. O programa 
ofereceu regularidade na produção e comercialização de uma variedade de produtos da agricultura familiar. De acordo com o presidente do STR-MC, Fábio Pinto, o principal efeito do PAA para os agricultores do município foi a valorização da produção e o conseqüente aumento da renda familiar. Vale recordar do caso de como o programa fez aumentar o valor do milho na região, citado anteriormente, além do mel.

Como a iniciativa garantia a compra pelo preço mínimo estabelecido pela Companhia Nacional de Abastecimento (Conab), no caso do mel, foi necessária a articulação da cooperativa para que a companhia pública definidora de preços aumentasse os valores pagos pelo produto tanto na Bahia quanto em Sergipe, considerados defasados pelos responsáveis pelo programa na Coopaf. "Aumentou R\$ 1,5. O mel estava R\$ 5 e agora estão pagando R\$ 6,50 o quilo, já envasado, com selo" (Zene Vieira, 2011, residência da entrevistada).

Em Morro do Chapéu, por exemplo, produtores de duas localidades forneceram mel de abelha para o PAA. Além de um grupo da comunidade de Umburaninhas, povoado localizado na área de caatinga do município, a Associação dos Pequenos Produtores da Chapada Diamantina (APPC) forneceu o produto para o programa público. A produção ocorria em caixas para abelhas mantidas na área coletiva do assentamento da associação. O PAA foi a forma de comercialização mais regular que a APPC teve para o mel.

O aumento de preços de produtos ou a sobrevalorização do valor local em relação ao definido pela Conab fizeram a cooperativa substituir nas cestas doadas, em alguns casos, itens cujos preços de mercado na região estavam muito acima daqueles estabelecidos pelo Programa de Garantia do Preço Mínimo para os Produtos da Agricultura Familiar (PGPAF). Isso aconteceu com o feijão, doado às comunidades carentes do município durante apenas um mês de execução do programa (Zene Vieira, 2011, residência da entrevistada). A queda vertiginosa da produção da cultura, que marcou a formação territorial da área do antigo distrito de Caraíbas, atual Irecê, ligada à questão climática e de trabalho, por "cinquenta anos de trator em cima deste solo descoberto, sem preparo" (Jaílson Rosa Rodrigues, 2011, propriedade do entrevistado na Malhada de Areia), encareceu o preço da saca do feijão.

Maria Aparecida, a Nena, de Fedegosos, fez parte do grupo de mulheres da localidade que forneceu beiju para a Coopaf por cerca de dez meses para o PAA durante o ano de 2008. Além de realizar os cuidados diários na propriedade que possui nas 
imediações do povoado, a agricultora extrai a farinha de tapioca da mandioca da própria roça e produz o beiju para vender na feira livre do povoado.

Para a agricultora, o PAA teve a função de complementar a renda. "A gente estava com um dinheirinho da gente na mão. O que a gente queria comprar, comprava com aquele dinheiro" (Maria Aparecida Leite Cardoso, 2011, residência da entrevistada). No período em que a produção era garantida pelo programa Nena produzia 62,5 quilos do produto por mês. Para isso, dedicava dois ou três dias inteiros de trabalho para uma atividade que antes só fazia para atender a demanda da própria família. Com o rendimento obtido com o programa, Nena (Figura 4.4.1) reformou a casa, trocou algumas portas velhas, comprou um guarda-roupa, comprou roupas, calçados e comida "para o consumo dentro de casa" (Maria Aparecida Leite Cardoso, 2011, residência da entrevistada).

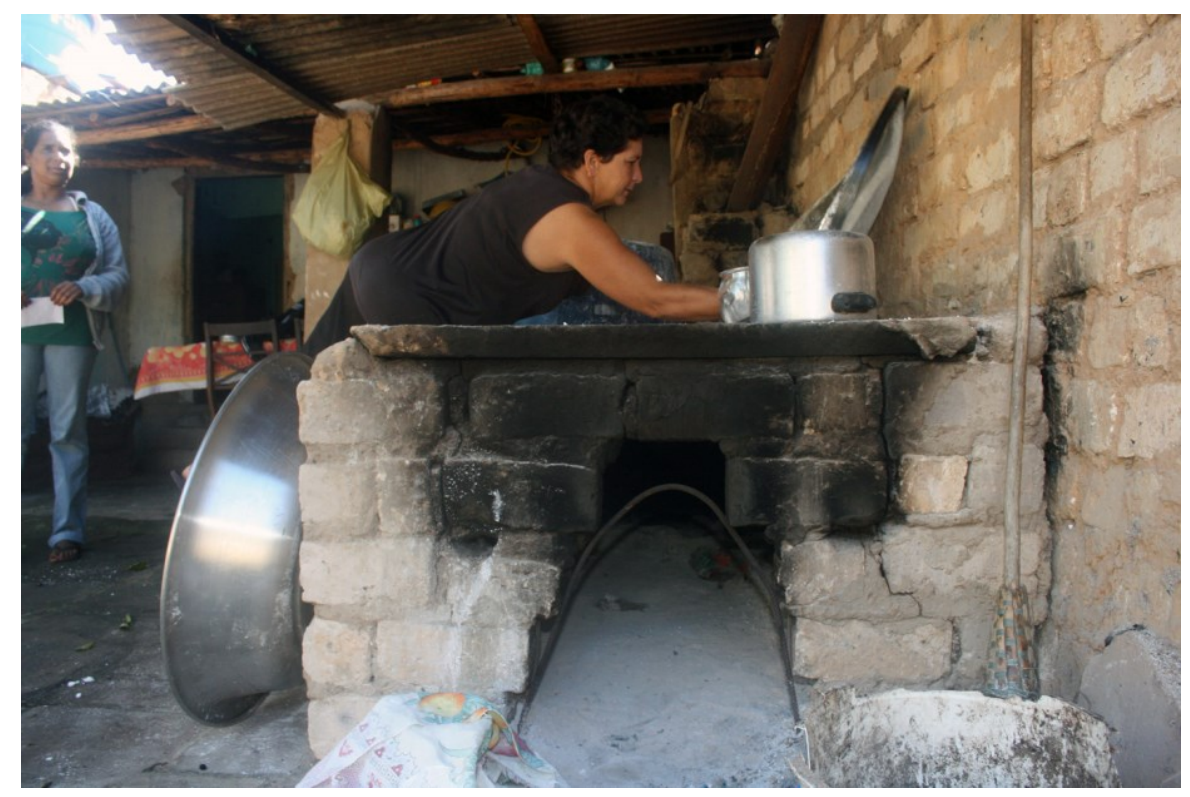

Figura 4.4.1 - A agricultora Maria Aparecida Leite Cardoso arruma o forno de barro construído nos fundos da casa no povoado de Fedegosos para fornecer beiju para o PAA. Foto: Vinicius Morende, em 03/07/2011.

Uma das companheiras de Nena no grupo de mulheres de Fedegosos que participaram da iniciativa foi Simone dos Santos Souza. Foi por meio de uma amiga conhecida da agrônoma Zene Vieira que Simone soube da oportunidade de fornecer para o PAA. Simone já havia trabalhado como atendente do posto telefônico de Fedegosos, ajudado o pai na pequena propriedade da família próxima ao povoado, e na época da oportunidade do PAA, com 33 anos, estava desempregada. 
Após entrar em contato com a agrônoma, ajudou a organizar o grupo que passou a fornecer o beiju para o programa público. A mãe de Simone, dona Heronildes, que começou a trabalhar ralando mandioca nas casas de farinha do povoado aos 11 anos de idade, em 1955, ensinou e ajudou a filha a produzir o alimento. Por ser a única do grupo que possuía um telefone na residência - ainda hoje o povoado não tem acesso ao sinal de telefonia móvel -, além da tarefa comum de buscar lenha, comprar ou extrair tapioca e produzir o beiju, Simone acabou se tornando a integrante do grupo responsável por organizar a produção e estabelecer o contato entre trabalhadoras e cooperativa.

O grupo começou produzindo o beiju na casa de farinha da associação comunitária de Fedegosos, mas logo algumas integrantes, como Nena e a família de Simone, construíram fornos de pedra nas próprias casas do povoado para facilitar a produção. Simone (Figura 4.4.2) também revela que o principal benefício de ter participado do PAA em 2008 foi a renda obtida.

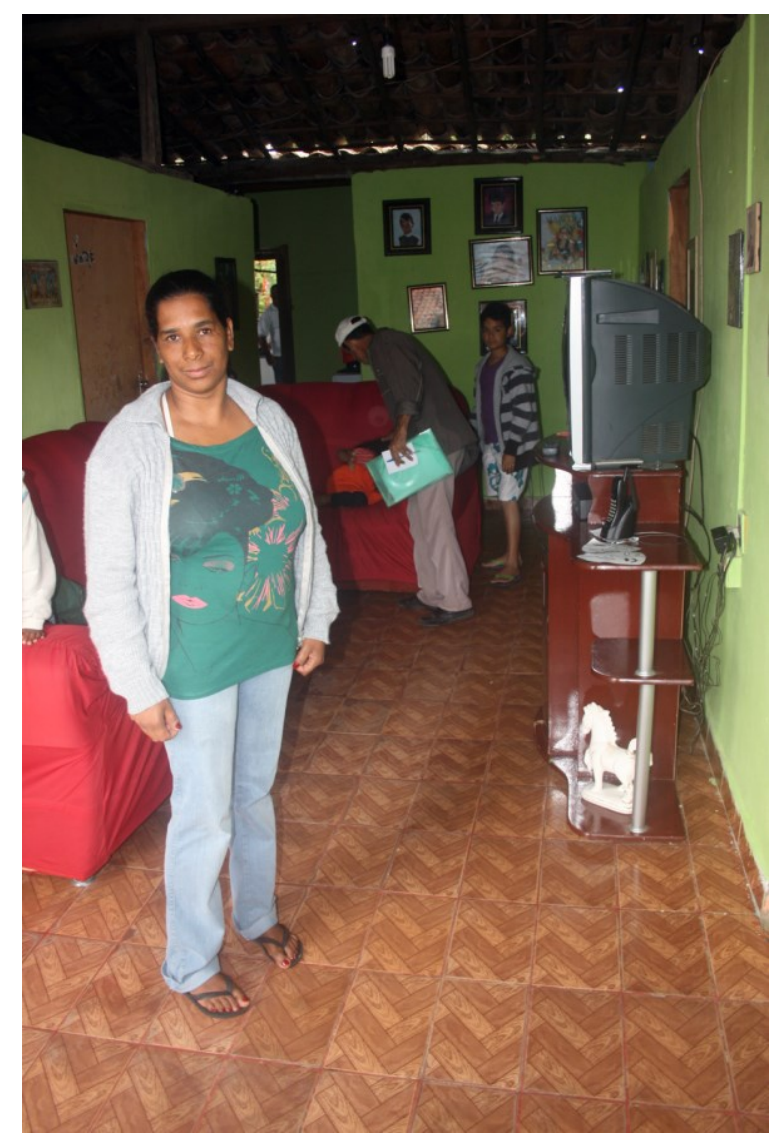

Figura 4.4.2 - Merendeira de uma escola em Fedegosos, no Morro do Chapéu, Simone dos Santos Souza posa para a fotografia ao lado da televisão que comprou com o dinheiro do PAA, dentro da casa em que vive com a família no povoado. Foto: Vinicius Morende, em 03/07/2011. 
No primeiro mês não deu pra tirar nada não. Foi só pra pagar lenha, a tapioca mesmo, essas coisas. Depois melhorou, sobrava um pouco, uns R\$200. Dava pra fazer alguma coisa. Isso foi por 10 meses. [...] O forno (de pedra na casa da família) a gente fez com o dinheiro do beiju. Esta televisão eu comprei e gostei. Deu pra pagar conta, comprar mais roupa, pra mim, pro meu filho (Simone dos Santos Souza, 2011, residência da entrevistada)

Após a Coopaf deixar de executar a modalidade do "Compra Direta" do PAA e mesmo com um forno na própria casa, dona Heronildes, a mãe de Simone, continuava indo algumas vezes durante o mês ralar mandioca na casa de farinha da associação comunitária de Fedegosos. Não por necessidade financeira, mas pela convivência com as amigas de atividade. "É bom demais, eu gosto" (Heronildes dos Santos, 2012, residência da entrevistada em Fedegosos). No início de 2012 eram pagos R $\$ 13$ para o serviço de um "diarista" nas casas de farinha do povoado.

Assim como o PAA tem no aumento da renda dos participantes um dos principais efeitos econômicos gerados em Morro do Chapéu, o mesmo aconteceu com o PNPB. O agricultor Jaílson Rosa Rodrigues (Figura 4.4.3), da Malhada de Areia, reflete que apesar de viver numa das regiões mais pobres da Bahia, hoje possui melhores condições de se alimentar.

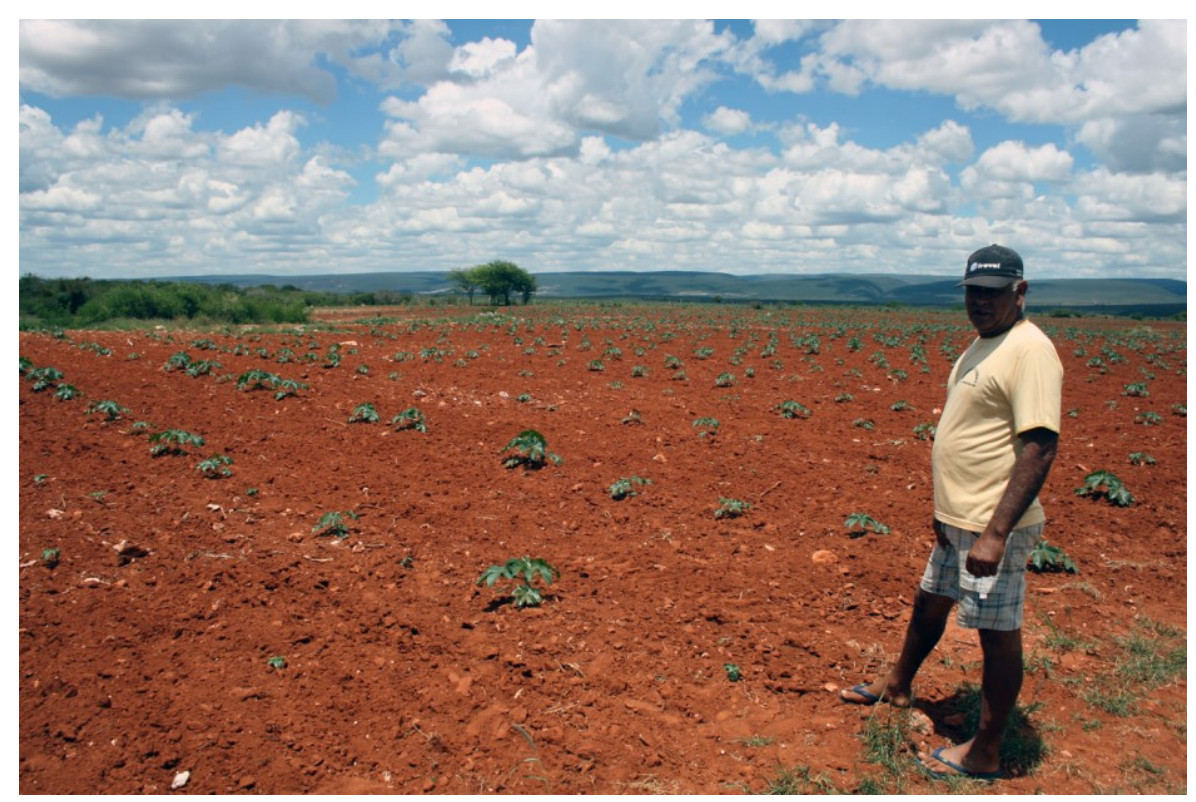

Figura 4.4.3 - O agricultor Jaílson Rosa Rodrigues em uma das propriedades que arrendou na Malhada de Areia para o cultivo da mamona. O preparo da área para o plantio havia sido realizado com a ajuda do trator de um familiar. Ao fundo estão as áreas da vereda Romão Gramacho e as serras do Parque Estadual de Morro do Chapéu (PEMC). Foto: Vinicius Morende. em 27/02/2011. 
Hoje, não temos vergonha de convidar pra almoçar. Porque com dois sacos de mamona aqui nós fazemos uma feira. Um cara como eu, com família pequena, com R\$ 180 na semana, compra sua carne, sua verdura. Coisas que o pobre nunca comeu está comprando hoje, comprando muito. O nível de compra da cesta básica para o pobre aqui do semi-árido aumentou e ninguém quer mais comer o feijãozinho de corda com ovo de galinha caipira. Quer comer é filé, macarrãozinho, salada, tudo. Mas antes nós passávamos era fome. Trabalhava com fome (Jaílson Rosa Rodrigues, 2011, propriedade do entrevistado).

De acordo com Fábio Pinto, o aumento da renda é indissociável do aumento no volume de postos de trabalho gerados a partir do programa do biodiesel no município. "É o que a gente diferencia mais: [geração de] empregos diretos e indiretos. O que mais empregou nestes últimos cinco anos foi o biodiesel. Técnicos, locadores de transportes, diarista, funcionário mesmo, locação de máquinas" (Fábio Pinto, 2011, STR-MC). A geração de emprego citada pelo sindicalista também revela mudanças em aspectos relacionados à organização da divisão do trabalho no meio rural.

Aquele cara trabalha aí pra mim, está vendo ali (Figura 4.4.4)? Ele trabalha para mim, mas é como se estivesse trabalhando para ele. Ele faz o que ele quer, na hora que ele quer. $\mathrm{O}$ dinheiro da feira dele não falta e ele tem outra coisa (terra) dele para lá. Sabe onde ia trabalhar? Naquele alto lá. Tinha que ir e voltar a pé. Sete horas tinha que estar lá. Cinco horas eu saía, chegava aqui cinco, seis horas da noite, a pé. É como nós vivíamos (Jaílson Rosa Rodrigues, 2011, propriedade do entrevistado). 


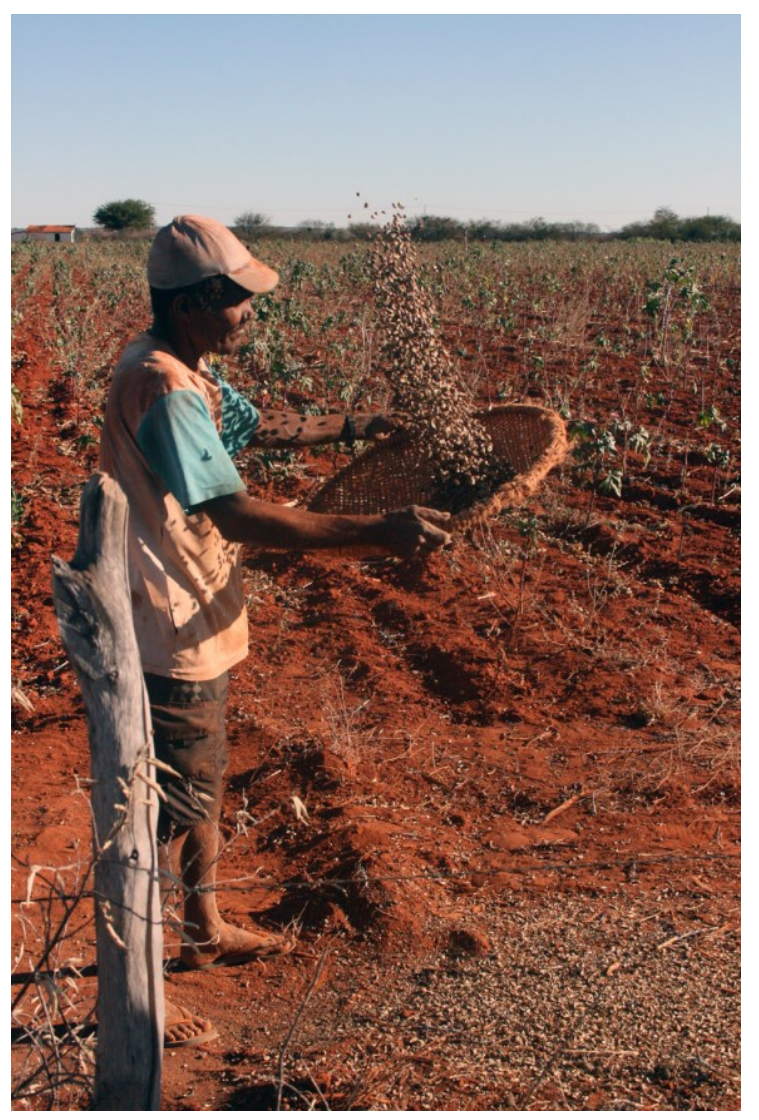

Figura 4.4.4 - O agricultor Florisvaldo Bispo Souza separa a palha da mamona na propriedade de Jaílson. Foto: Vinicius Morende, em 07/07/2011

O agricultor Florisvaldo Bispo Souza trabalha com Jaílson Rosa Rodrigues, da Malhada de Areia, possui uma propriedade próxima da localidade e é um exemplo de pequeno proprietário que também exerce a função de diarista, aqueles que "vendem" o dia de trabalho para outros proprietários. Como o volume de trabalho aumentou em diversas localidades por conta da intensificação da produção da mamona pelo PNPB e de alimentos pelo PAA houve mais oportunidades de trabalho, tanto para aqueles que pretendiam complementar a renda obtida com a roça própria quanto para aqueles que não possuíam propriedades.

No entanto, a propriedade, condição inerente aos entrevistados desta pesquisa, difere os agricultores familiares dos trabalhadores que são apenas "diaristas", que não possuem a posse da terra. Esse fator é determinante para que o pequeno proprietário possa receber a concessão da Declaração de Aptidão ao Pronaf (DAP), ser reconhecido como agricultor familiar e possa ser beneficiado por programas como o PNPB e o PAA. Os trabalhadores que não possuem a propriedade da terra estão sujeitos a mais variáveis, como a escassa oferta de emprego nos períodos de baixa produção da mamona. 
Rosemiro José da Silva, do Icó, afirma que depois da chegada da Coopaf e do aumento de preço da mamona, a categoria passou a ter uma condição financeira melhor. De acordo com ele as melhorias não beneficiaram só os agricultores. Os fluxos comerciais também se intensificaram. "Se o comércio teve uma melhora, foi por causa da renda da lavoura. Porque o comerciante só vai à frente se o consumidor tiver condição para ajudar o comércio" (Rosemiro José da Silva, 2011, residência do entrevistado).

Com a lavoura deu para nós resolvermos nossos problemas e fazer compras. Com essa ajuda, nós pegamos mais dinheiro e ajudamos o comércio. Melhorou para tudo. Se a mamona não desse um valor para pagar o trabalhador, a não ser aquele precinho baratinho, eu, nem ninguém podia pagar o trabalhador, nem a despesa particular da roça (Rosemiro José da Silva, 2011, residência do entrevistado).

O agricultor compara ainda as condições de vida em 2010, quando houve boa safra e a cooperativa estava comercializando a produção de mamona, e em meados de 2011, após a falta de chuvas ter afetado as safras e sem a participação da Coopaf na disputa pela compra da cultura.

\footnotetext{
No ano passado e no ano anterior, em que nós tivemos safra, tinha ajuda da roça, a gente tinha condição de manter as responsabilidades da gente e ajudar os outros. [...] Só tem muito trabalho quando chove, quando tem muita lavoura. Este trabalho, limpando o pé de cerca, quebrando a mamoninha, eu é que venho fazendo. Tem vezes que me aparece um pai de família. '- Moço, me paga um dia ou dois de trabalho que eu não tenho condição de fazer a feira'. Moço eu não tenho trabalho. Tenho um dinheirinho quando tem a lavoura (Rosemiro José da Silva, 2011, propriedade do entrevistado).
}

Quando a lavoura é prejudicada, Rosemiro, assim como outros agricultores, recorre à aposentadoria e à pequena criação de animais que possui para prover o sustento da casa e ajudar um ou outro conhecido. "Tem vezes que para servir um pobre coitado numa situação pior que a minha, eu pago um dia ou dois de trabalho. Então, quando é época boa não precisa disso" (Rosemiro José da Silva, 2011, propriedade do entrevistado). Ou seja, apesar dos avanços dos programas públicos analisados, em alguns períodos, não há garantias de que somente o trabalho na roça promova o sustento da maior parte das famílias. 


\subsection{Aumento dos fluxos entre zona rural e sede}

De acordo com Fábio Pinto o aumento da renda após o programa do biodiesel, a pressão popular para que se consertassem as estradas e convênios com o governo do Estado para a recuperação das estradas vicinais do município contribuíram para o melhoramento do transporte da zona rural para a sede do município. "Quando você tem dinheiro pra gastar, você começa a frequentar mais a área urbana do município, a sede do município. Isso gerou mais emprego. Tem muito taxista fazendo linha das roças para a sede do município, sobretudo de sexta-feira, que é o dia de feira" (Figura 4.5.1) (Fábio Pinto, 2011, STR-MC).

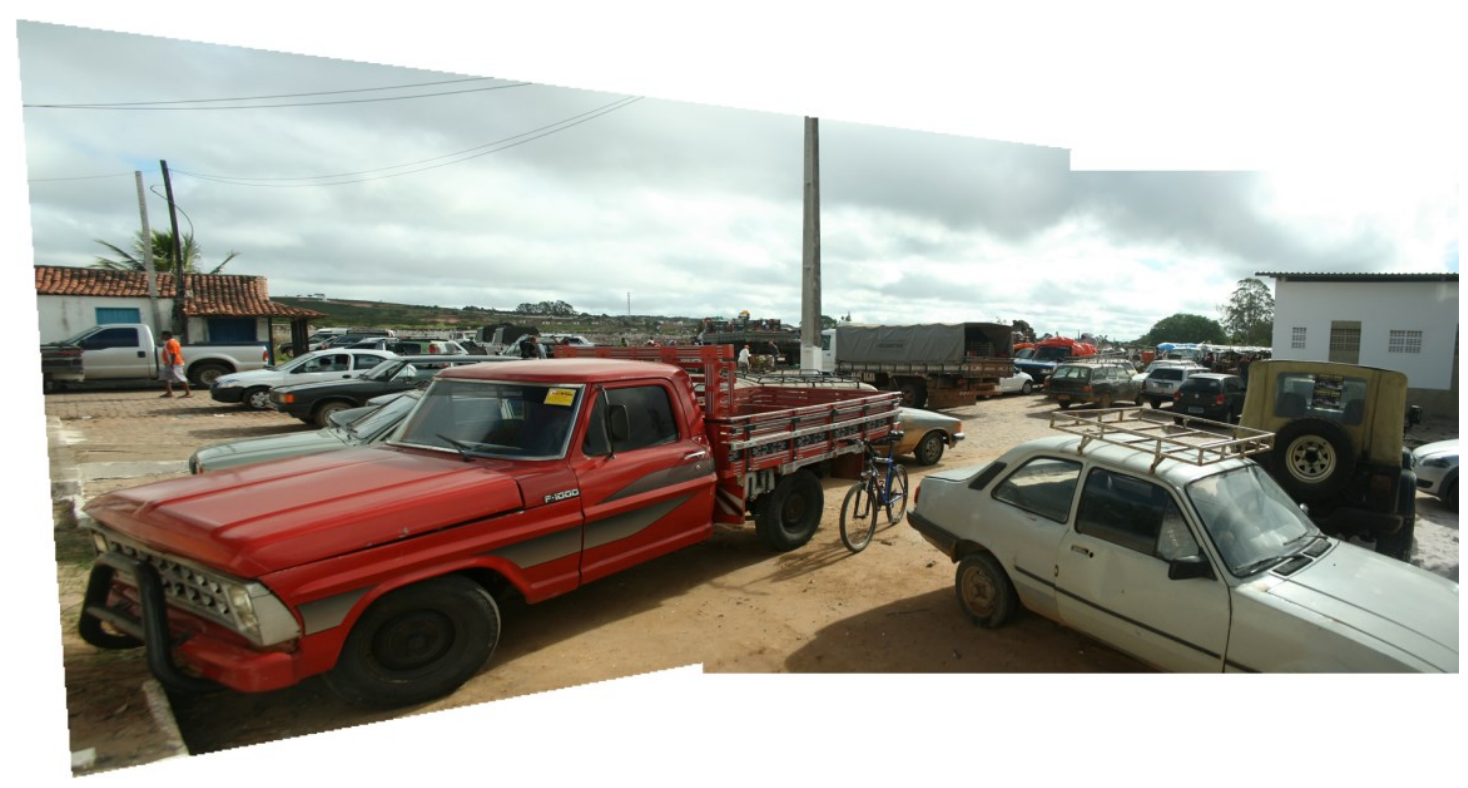

Figura 4.5.1 - Fotomontagem da área do estacionamento da feira livre de Morro do Chapéu numa sexta-feira. No local são estacionados, principalmente, veículos trazendo mercadorias da zona rural para a sede. Foto: Vinicius Morende, em 24/02/2012.

A influência de uma série de avanços relacionados à infraestrutura do município e do sertão em geral durante o processo de formação territorial que se deu em Morro do Chapéu a partir de 2007 contribuiu para a intensificação dos fluxos de pessoas, mercadorias e informações. O maior acesso ao dinheiro fez também os fluxos serem intensificados entre as propriedades rurais e os povoados e dos povoados para a sede ou para as principais cidades vizinhas. Seja porque os agricultores tenham passado a possuir renda para adquirir o próprio veículo, o que facilitou as viagens, ou pagar pelos 
serviços particulares de transporte com regularidade, com a melhoria das estradas, o tempo para percorrer as distâncias foi reduzido.

É possível identificar o aumento nos fluxos entre a zona rural e a cidade como um dos principais efeitos do aumento da renda, principalmente, após 2007. Neste caso, houve tanto a modernização da frota como o aumento do número de veículos circulando. Para o presidente do STR-MC o transporte é o setor que mais evoluiu e o plantio da mamona, aliado à influência da produção de café, mudou a cara da zona rural do município nos últimos anos. Isso também justificaria a chegada de duas revendas de motocicletas e de uma série de lojas de peças para motos nos últimos dois ou três anos na sede de Morro do Chapéu. "Moto é um transporte mais barato e todo mundo que tem condições está comprando" (Fábio Pinto, 2011, STR-MC).

O aumento da renda incentivou a aquisição de veículos pelos habitantes da zona rural. "Agora todo mundo tem sua moto, tem seu carro" (Jaílson Rosa Rodrigues, 2011, propriedade do entrevistado). Quando precisava resolver algum problema, principalmente, de ordem burocrática Jaílson pagava tarifas de R $\$ 15$ para ir até a sede de Morro do Chapéu "no carro dos outros” (Jaílson Rosa Rodrigues, 2011, propriedade do entrevistado).

$\mathrm{O}$ agricultor ressalta que ele próprio conseguiu comprar um carro depois do PNPB. O bem foi adquirido depois de receber mais de R 5.000 da Coopaf pela venda da produção de mamona. "Comprei o carro por R\$4.500, ainda sobrou um troco, uns R\$ 700 e pouco e eu ainda fiz uma roça" (Jaílson Rosa Rodrigues, 2011, propriedade do entrevistado).

\footnotetext{
Você está vendo aí que todo mundo tem sua moto. Tem um vizinho meu aqui que tem um carro e uma moto. Antigamente era uma bicicleta e um jegue, há uns oito, dez anos atrás. O nosso sucesso foi depois do biodiesel, da garantia de preço e venda. [...] Este vizinho meu aí, agora mesmo, ele bateu quase 70 sacas de mamona. Ele foi a Feira de Santana e comprou um carrinho. Ele vendeu um carro velhinho que ele tinha por R $\$ 1.500$ e comprou um melhor (Jaílson Rosa Rodrigues, 2011, propriedade do entrevistado).
}

Ao afirmar que a melhoria da qualidade de vida proporcionada após a criação do programa do biodiesel é uma das principais mudanças ocasionadas pela iniciativa, Lula, do Velame, revela que, além de geladeira e fogão, muitas famílias que vivem na região também conseguiram adquirir o automóvel. "Isso mudou bastante" (Luciano Bernardo de Brito, 2011, propriedade do entrevistado). 
Esses fluxos podem ser sinais da evolução do nível das relações econômicas de uma maneira geral no meio rural e na sede no município. A evolução técnica nas propriedades rurais, o crescimento do comércio e a disponibilidade de serviços na sede de Morro do Chapéu nos últimos anos também podem ser considerados variáveis da condição econômica que contribuíram para o aumento dos fluxos.

No caso do comércio, o crescimento do volume financeiro em circulação, exposto por uma série de estabelecimentos criados nos últimos anos, se deu tanto por conta das mudanças estruturais que influenciaram a região quanto pela instalação da Coopaf na sede do município. A atividade em geral evoluiu conforme a cooperativa contratava profissionais e negociava mamona e regrediu quando a PBio interrompeu a compra e os salários dos trabalhadores atrasavam. O presidente do STR-MC confirma este processo.

\footnotetext{
Hoje, a participação da mamona no programa do biodiesel passa por um momento de indefinição. O preço da saca da mamona está alto, $\mathrm{R} \$ 90, \mathrm{R} \$ 95$. A Petrobras recuou na compra. E por incrível que pareça o comércio local sentiu o efeito. Por quê? Para explicar isso é um negócio um pouco complicado, mas no caso do biodiesel, o dinheiro fica no município. Quando você vende para o mercado do óleo, esse dinheiro já não fica no município. Quem ganha mais são os atravessadores. O próprio comércio hoje aí sente. O maior contrato da cooperativa é com a Petrobras, $80 \%, 90 \%$. Se a Petrobras deixa de comprar e operar esse contrato, o próprio comércio hoje já sente e os comerciantes falam que o grande problema para eles no momento é que a Coopaf deu uma parada no ritmo de produção que vinha tendo. Eu digo, a Coopaf por ser a principal cooperativa de comércio aqui e estar instalada no município (Fábio Pinto, 2011, STR-MC).
}

O agricultor José Barbosa de Jesus se mostrava impressionado com a evolução da oferta de crédito ao consumidor nos últimos anos na sede de Morro do Chapéu. "Eu vejo tanta coisa que não tinha. Vejo mercado, a gente anda naquela feira, nas lojas todo mundo fica lhe chamando. Se o cara é da roça, chega, você tem crédito pra comprar. Ninguém tinha crédito para comprar nada" (José Barbosa de Jesus, 2011, propriedade do entrevistado).

Mesmo o engenheiro agrônomo Fabrício Amorim, que passou a viver em Morro do Chapéu a partir de 2008, consegue identificar mudanças relacionadas ao PNPB para a sede da cidade desde então.

Mudou bastante, neste período mesmo de compra de mamona, que é o período que gera muito recurso, a circulação de recurso no município é grande. A Coopaf consegue mexer com muito recurso mesmo dentro do município. Pegando só a questão de imposto que a cooperativa paga para a prefeitura, de serviços que ela presta. [...] É emprego que gera dentro do município, é a 
aquisição de materiais e tudo mais. A própria cooperativa cria empregos, que geram recursos também (Fabrício Amorim, 2011, residência do entrevistado).

O comércio nos povoados e na sede de Morro do Chapéu e das cidades próximas também foi influenciado, principalmente, pelo avanço das atividades do PNPB e se intensificou. Novos estabelecimentos foram abertos, o acesso ao crédito foi facilitado e, com mais recursos financeiros, o consumo aumentou. Pequenas empresas prestadoras de serviços, como de informática, despachantes, entre outros se instalaram em Morro do Chapéu. A própria Coopaf passou a tentar investir em outras cadeias produtivas agrícolas como a do sisal, que possui histórico de produção na região do Icó e Brejões.

Um dos povoados onde é possível identificar a evolução após o início do PNPB é o do Icó. O agricultor José Barbosa de Jesus, o Zé Capoeira, afirma que nos últimos anos o povoado passou por mudanças que beneficiaram, principalmente, quem tem a propriedade da terra.

O comércio aí [no Icó] é bom. Porque a pessoa que tem um armazém, um depósito, ele não para de vender não. Tem uma cidade aqui, Várzea Nova, o povo vai fazer a feira no dia de hoje. Todo mundo vai pra lá. Quem é do sisal, quem é da roça, vai todo mundo. Quando dá cedinho, você vê, sai dez, 12 carros cheios de gente. Vão pra lá. E aqueles que não ficaram aqui foram embora pra Goiás, porque não tinham porque ficar. Foram embora porque não tinham uma roça (José Barbosa de Jesus, 2011, propriedade do entrevistado no Icó).

Por outro lado, a valorização da produção de mamona também gerou efeitos relacionados à maior fixação do homem na zona rural em Morro do Chapéu. Para o sindicalista Fábio Pinto "o número de pessoas que deixou de sair no campo, que ainda é alto", diminuiu bastante (Fábio Pinto, 2011, no STR-MC). "O homem fixou-se no campo e deixou-se de vender tanta terra quanto estava se vendendo. Passou-se a investir na recuperação de várias propriedades que estavam abandonadas" (Fábio Pinto, 2011, no STR-MC).

Jaílson, da Malhada de Areia, também afirma conhecer muitas pessoas que deixaram a região nos últimos anos e que voltaram para trabalhar. "Tem amigo meu que saiu daqui, gente de pai que é até bem de vida, mas foi obrigado a ir embora para São Paulo e voltou. E está no intuito de plantar mamona. Porque ficou bom. Voltou pra plantar" (Jaílson Rosa Rodrigues, 2011, propriedade do entrevistado).

Apesar de alguns avanços técnicos e a geração de novos postos de trabalho a partir da valorização da mamona, a história da agricultura em Morro do Chapéu ainda é 
semelhante à da maioria dos municípios do sertão nordestino. A constante migração da população, especialmente dos jovens que atingiram a fase adulta e cujas famílias não possuem terras, ou as possuem em espaço insuficiente para todos os descendentes, fazia a cidade ser fornecedora de mão-de-obra para outras regiões do país.

A pesquisa de doutorado do geógrafo Rogério Haesbaert da Costa esbarrou neste problema quando este pesquisava o sertão da Bahia. Ao citar a possibilidade da existência de aglomerados de exclusão tanto na mobilidade atroz e sem direção definida quanto na quase completa imobilidade (HAESBAERT, 2007, p. 329), o pesquisador utiliza o exemplo de uma família de sertanejos que conheceu na cidade de Barreiras no início da década de 1990. Após terem passado muito tempo "presos à terra", "numa condição de extrema miséria", numa situação de territorialização precária, se tornaram alvo fácil de uma “desterritorialização na mobilidade” (HAESBAERT, 2007, p. 329).

Na prática, convivendo com a fome e a sede no interior do Rio Grande do Norte, a família havia fugido da seca e migrado até a cidade do oeste baiano onde acampava junto a outras famílias de origens semelhantes na beira da BR-242, que liga Salvador à Brasília. Para chegarem a Barreiras haviam viajado 1.500 quilômetros por 20 dias a pé ou de carona em caminhões. No caminho, "passaram por Juazeiro, onde a seca era ainda mais grave e Morro do Chapéu, uma das cidades mais altas da Bahia, onde afirmam ter passado muito frio" (HAESBAERT, 2007, p. 330).

A condição de flagelo na qual Haesbaert (2007, p. 330) encontrou tal família é semelhante à da maior parte das famílias que vivem em Morro do Chapéu e não possuem propriedades rurais. Um caso simbólico das perspectivas para a juventude do lugar é o de um rapaz de pouco mais de 20 anos, filho da terra. Em meados de 2008, o jovem, sem emprego, tinha nas costas a promotora pública e diferentes ex-amantes lhe cobrando a pensão de cinco filhos e no currículo uma fuga de uma propriedade rural no interior de Goiás. Fugira após passar alguns meses trabalhando em condições análogas à escravidão. Em 2011, passou a atuar como técnico da Empresa Baiana de Águas e Saneamento (Embasa) no município com um contrato temporário, arranjado com o apoio de conhecidos na prefeitura.

Devido à acumulação histórica, e não resultado dos recursos "naturais" que dispõem (AGNEW, 2011, p. 6), a relativa estagnação econômica das localidades analisadas, principalmente, até o desenvolvimento das dinâmicas do PNPB, prejudica as classes menos favorecidas da sociedade. As condições impostas ao território de Morro do Chapéu ao longo da história pós-colonização fizeram, em alguns períodos, as secas 
provocarem a fragmentação quase total da estrutura social de áreas do município baiano.

No caso de Morro do Chapéu, o chefe político Jubilino Cunengudes ressalta uma das épocas de crise hídrica no município, entre 1930 e o início de 1933 "não havendo por isto, produção" (CUNEGUNDES, 1981, p. 35). "Os pequenos agricultores já sem recursos, com a perda da lavoura, seus pequenos estoques de gêneros alimentícios esgotados [...] em desordem foram abandonando os campos, em busca das Cidades" (CUNEGUNDES, 1981, p. 35).

No início de 2012, Morro do Chapéu também estava há sucessivos meses sem chuvas regulares. A situação, porém, castigava algumas localidades com mais intensidade, provocando a migração temporária ou definitiva dos trabalhadores. As criações eram as últimas a resistir antes das pessoas. De acordo com o presidente do STR-MC, na época, a falta de chuva escasseava a pastagem e a alimentação do "bovino, caprino, os animais" (Fábio Pinto, 2012, no STR-MC).

Como a situação na área urbana do município era "ainda pior" (Fábio Pinto, 2012, no STR-MC), os pequenos agricultores migravam para Minas Gerais e São Paulo para trabalhar em colheitas e lavouras. As áreas mais afetadas pelo problema no município eram as que abrangiam os povoados de Lagoa Nova e Ouricuri, este, próximo ao do Velame. De acordo com o sindicalista, nas outras regiões também não havia chovido, mas por tradição, aquelas eram as áreas mais afetadas. "A região de Lagoa Nova por conta da cultura do café. Na região de Ouricuri, a mamona e o feijão e o milho que também não produziram nada" (Fábio Pinto, 2012, no STR-MC).

É importante considerar a irregularidade da distribuição das chuvas que ocorrem no município. "Acontece que nós temos aqui 200 milímetros de chuva em um dia e passa 200 dias sem chuva" (Jaílson Rosa Rodrigues, 2012, residência do entrevistado). Mesmo em espaços mais amplos, que agrupam diversas localidades, a incidência de pluviosidade varia. Enquanto na área de Ouricuri ocorreu a perda quase total da safra, no Velame e na Malhada de Areia a perspectiva de colheita da mamona era positiva na mesma época.

De acordo com Jaílson, da Malhada de Areia, as chuvas no início de 2012 eram poucas, mas regulares. "Choveu, de Irecê, da região, pra cá, choveu tudo. Choveu bastante. E aqui está bom. Por sinal a mamona está muito boa” (Jaílson Rosa Rodrigues, 2012, residência do entrevistado). Por outro lado, em comunidades próximas a seca havia impossibilitado até mesmo o plantio. "No povoado de Boa Hora ali, aqui perto de 
Cafarnaum, divide com o Morro do Chapéu, não deu chuva ainda. Está seco, está terrível" (Jaílson Rosa Rodrigues, 2012, residência do entrevistado). Mesmo em Fedegosos, localidade situada numa região relativamente mais úmida do município, a seca também marcava as formas espaciais no início de 2012 (Figura 4.5.2).
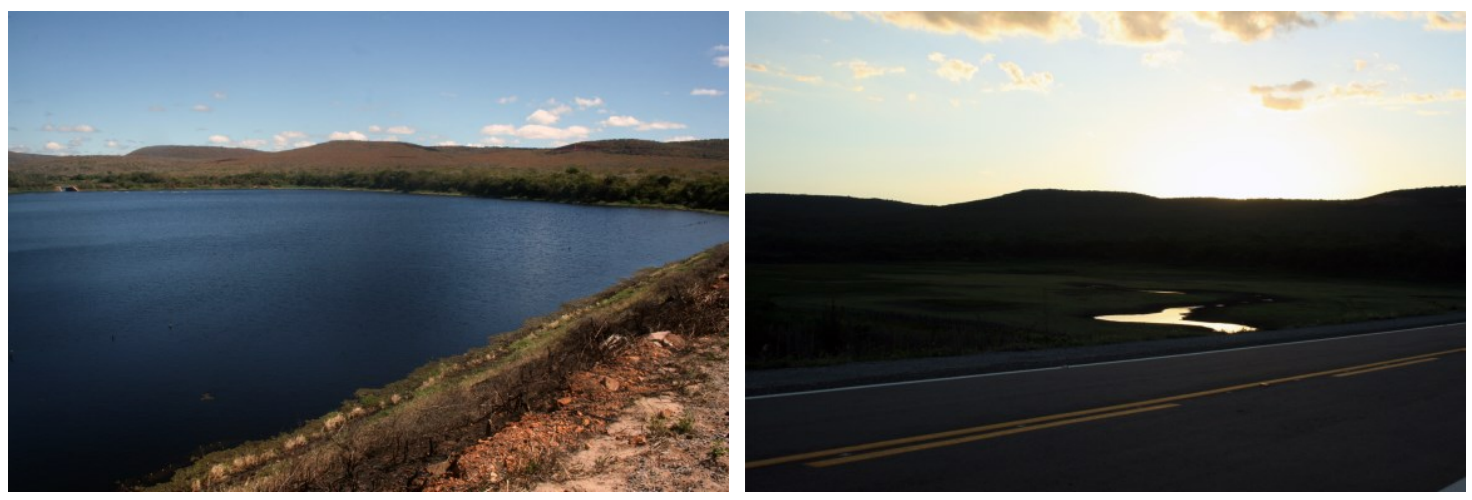

Figura 4.5.2 - Imagens comparativas da barragem do Angelim, em Morro do Chapéu, em 03/07/2011 (esq.), vista da margem esquerda da rodovia BA-052, e em 28/02/2012, da outra margem da estrada. Localizada na interseção da rodovia com o rio Preto, ou do Ventura, um dos afluentes do rio Jacuípe, o nível da barragem em 2012 era o menor desde 2007. Fotos: Vinicius Morende

\subsection{Mecanização e intensificação técnica}

A valorização da cultura da mamona também intensificou a mecanização da agricultura em Morro do Chapéu, especialmente no oeste do município. "Trator era uma máquina que ninguém queria. As duas revendedoras de tratores que tem aqui da Valtra e da Massey Ferguson, em Irecê, batem recordes de venda. Foi o programa que, aliado à questão da irrigação, começou a trazer de novo esta prática para cá” (Fábio Pinto, 2011, no STR-MC).

O agricultor Jaílson, da Malhada de Areia, utiliza o exemplo de um trator adquirido pelo tio dele para demonstrar a melhoria de vida proporcionada pelo programa do biodiesel. O familiar do agricultor recentemente adquiriu o maquinário para cultivar mais de 200 tarefas de várias culturas com o filho. "Aqui nunca teve um trator" (Jaílson Rosa Rodrigues, 2011, propriedade do entrevistado).

De acordo com o agricultor, após vender 300 sacas de mamona, o parente estava prestes a adquirir o segundo trator no início de 2012. Só não o fizera antes, pois era avalista de um conhecido que havia se endividado com o cultivo do feijão. "O sucesso 
da gente é o biodiesel. Nossa vivência aqui era sofrimento" (Jaílson Rosa Rodrigues, 2011, propriedade do entrevistado). O próprio Jaílson contou com o apoio do maquinário do familiar para realizar o preparo do solo para o plantio de mamona, o que permitiu ao agricultor arrendar terrenos vizinhos e ampliar o espaço cultivado. Para tanto, Jaílson, que trabalha com irmãos e cunhados, pagou cerca de R\$ 1.000 pelo serviço que o familiar também passou a prestar a outros produtores da vizinhança.

Isso aconteceu, pois a intensificação técnica representada pela mecanização alterou também a temporalidade relacionada ao plantio de diferentes culturas produzidas pela agricultura familiar. De acordo com Zé Capoeira, do Icó, quando o serviço de plantio do feijão era realizado de forma manual, por exemplo, era necessária uma semana para plantar uma saca do produto em duas ou três pessoas, numa época em que se semeavam dez, doze sacos de feijão por vez. "Aí o povo está lutando aí. Tem o trator, chega, você paga, dá plantadinho. O trator bateu, você bota na carroça, vai pra casa. Quem vem bater o feijão quer mais dez, 15 sacas, vem com a caminhonete, bateu, botou em riba, ele ganhou o dinheiro, fez tudo" (José Barbosa de Jesus, 2012, propriedade do entrevistado).

\footnotetext{
Hoje em dia, tem muito proprietário que tem trator na rua. Aluga. Eles ganham dinheiro para arar uma terra por hora. Para gradar uma terra, por hora. Tem uma roça de 10 tarefas, ele dá duas, três horas, gradou, ligeirinho. Em duas horas, três, você gradou 10 tarefas de terra. '- De tardezinha venha plantar meu feijão'. Tardinha ele chega com uma plantadeira, já sai plantado. No dia de cultivar, a gente tem uma capinadeira, todo mundo tem um animal. Em dois ou três dias cultiva todinha na capinadeira as carreirinhas de feijão, pronto. Olha o feijão limpo aí, acabou. Naquele tempo era na enxada (José Barbosa de Jesus, 2012, propriedade do entrevistado).
}

A temporalidade do feijão pode ser considerada mais curta que a da mamona, que possui um ciclo maior de cultivo, ocupando, consequentemente, por mais tempo o espaço das roças dos agricultores. Para Rosemiro, do Icó, o tempo gasto com esta cultura seria desperdiçado caso atores como os atravessadores voltassem a dominar completamente o controle dos preços da cultura. Na lógica do agricultor, os atravessadores não comercializam a mamona para a indústria ricinoquímica por um preço menor do que aquele praticado entre agricultores e cooperativa. Além disso, os atravessadores dedicam pouco trabalho à cultura comparado ao tempo ou dinheiro investido pelos agricultores nas roças. 
Ele tem o transporte próprio, não sei quantos. Ele compra e conduz direto pra firma (ricinoquímica), sem despesa nenhuma. Nós trabalhamos um ano, um ano e tanto e quando nós colhemos ela, que dá no ponto de nós vender, toda a despesa está metade do preço dela. Então nós já vendemos por metade do preço. O que nós estamos fazendo? Perdendo tempo não é? (Rosemiro José da Silva, 2012, residência do entrevistado).

Outro aspecto relacionado à expansão da ocupação da cultura da mamona em Morro do Chapéu e à recuperação de propriedades rurais no município é exatamente a falta de áreas mantidas em "pousio", ou repouso, que promovam a recuperação dos solos e o posterior cultivo. Luciano Bernardo de Brito, o Lula, ressaltava a qualidade da mamona plantada na propriedade do pai no Velame numa área que ficou "abandonada durante alguns anos" (Figuras 4.6.1 e 4.6.2).
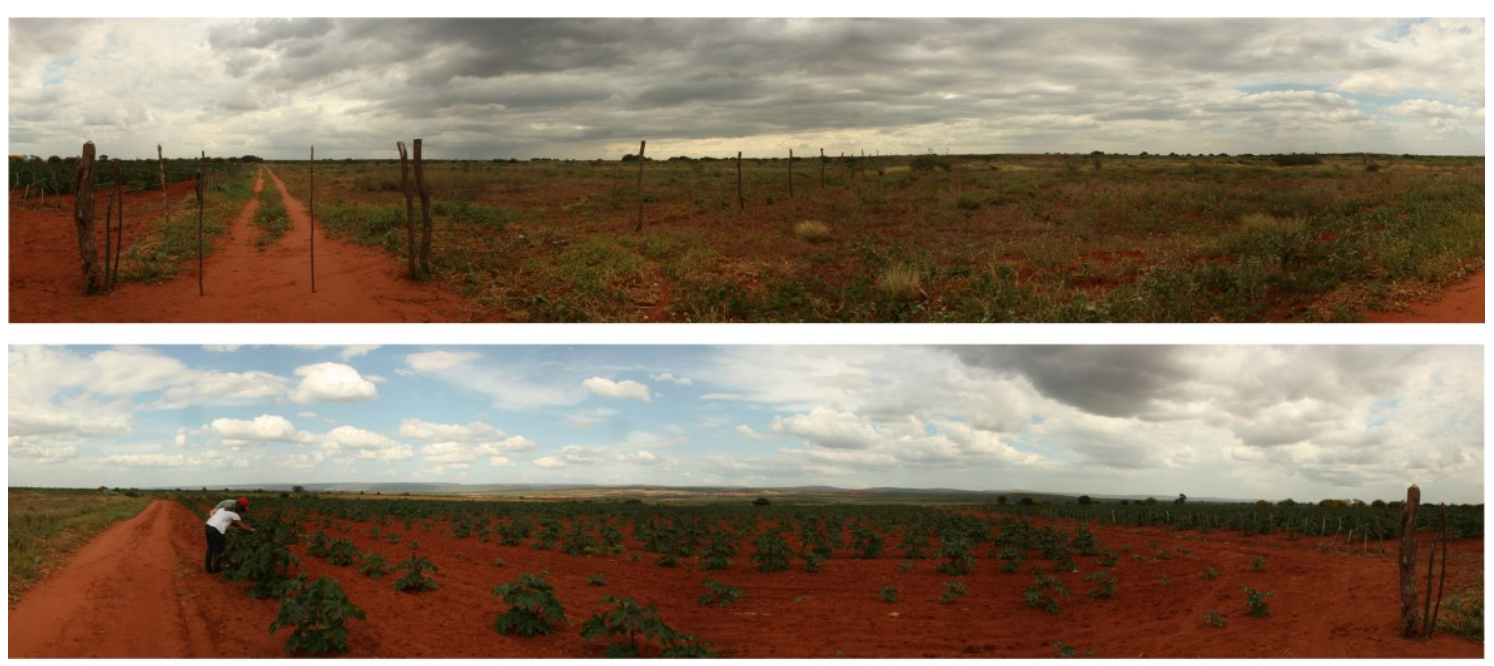

Figura 4.6.1 - Montagem de fotos com vista panorâmica $\left(360^{\circ}\right)$ da propriedade da família de Luciano Bernardo de Brito, do Velame, em meados de fevereiro de 2012, quando as chuvas atingiram algumas localidades da região após meses de estiagem. A parte de cima da montagem mostra a área da propriedade mantida em repouso por alguns anos e, no horizonte, a chuva que caiu sobre algumas áreas. A imagem de baixo mostra a área que ficou em repouso e que havia sido plantada com mamona algumas semanas antes. Fotos: Vinicius Morende, em 24/02/2012. 


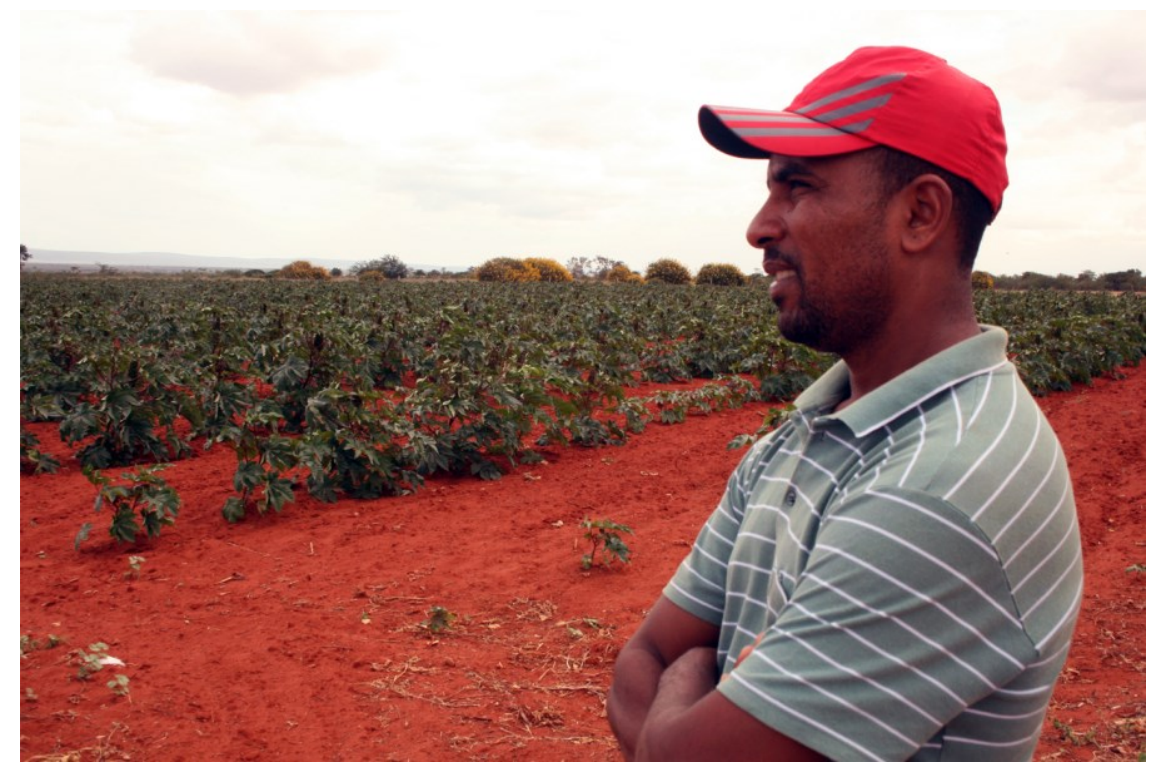

Figura 4.6.2 - Luciano Bernardo de Brito, o Lula, do Velame observa a lavoura na área que fora mantida em repouso na propriedade da família. Foto: Vinicius Morende, em 24/02/2012.

Deixou de plantar, empastou, deixou o mato tomar conta e agora ele voltou. O que deixa nítido e claro a necessidade de se fazer a rotatividade de culturas. Ele plantava só mamona, só mamona e a mamona chegava a não produzir. Dava os primeiros cachos, mas depois morria. Abandonou uns quatro anos e agora que ele voltou com a mamona. Está um espetáculo, na mesma área (Luciano Bernardo de Brito, 2012, residência do entrevistado).

A questão da rotatividade de solo, no entanto, se torna problemática para a agricultura familiar em Morro do Chapéu, que em geral possui propriedades rurais não muito extensas. Pelo menos não o suficiente para abrir mão da possibilidade de obter renda com alguma cultura, como a mamona, ao invés de manter áreas em repouso. "É o que acontece com as áreas dos meus tios. Tem que plantar e só tem aquela área pequena. Não tem mais onde plantar. E continuam plantando sempre a mesma cultura. Porque é a única cultura que ainda dá alguma coisa. Acaba matando a terra aos poucos" (Luciano Bernardo de Brito, 2012, residência do entrevistado).

O problema de ordem fundiária é evidente na localidade do Velame, um povoado de remanescentes quilombolas. Apesar do reconhecimento da comunidade ter sido realizado em 1997, até hoje a propriedade na qual os antepassados dos atuais habitantes viveram não passou por processo de regularização fundiária. De acordo com o pai de Lula, André de Brito, o seu Dezinho, a área da família era muito mais ampla do que a atual, mas passou por um processo intenso de grilagem ao longo das décadas. Restou para cada integrante da família de Seu Dezinho menos de dois hectares para cultivar. 
Nós até fomos no Morro do Chapéu, eu, um tio meu que tem na América [Dourada], Gervásio, para nós tentarmos tomar providência pra ver se nós conseguíamos estes terrenos, mas não tinha jeito. Nesta época, do finado Jubilino [Cunegundes], o que fizesse tava feito. Ô velho danado. Aí eu sei que nós perdemos tudo. Nossas terras. Era muita terra (André de Brito, residência do entrevistado no Velame).

A intensificação do meio técnico, representada por fatores como a mecanização da lavoura, por outro lado, também gerou novos postos de trabalho e a qualificação de alguns trabalhadores. Além dos operadores de maquinário e fretadores, o aumento da renda promoveu também serviços de empresas de perfuração de poços artesianos em Morro do Chapéu. Os filhos de Zé Capoeira, do Icó, por exemplo, “aprenderam a furar poço e estão trabalhando com maquinário" (José Barbosa de Jesus, 2012, propriedade do entrevistado).

As mudanças que passaram a acontecer com mais intensidade na escala local após 2007, advento da evolução do meio técnico-científico-informacional em Morro do Chapéu, expõem as contradições do atual esquema de participação da agricultura familiar em programas públicos. Isso porque, quanto mais o sertanejo começa a prestar serviços fora de sua propriedade, ou seja, quanto maior for a "renda extra-rural", menor é a possibilidade de ele manter-se dentro de um dos critérios básicos para ser considerado agricultor familiar pelo poder público federal e de ser beneficiado por programas como o PNPB e o PAA.

De acordo com Fábio Pinto o movimento sindical defende outros critérios para a concessão da Declaração de Aptidão ao Pronaf (DAP), que possibilita a participação nos programas citados e que determina um limite desta renda extra-rural obtida. Uma das incoerências atuais do sistema seria a de que enquanto esta renda é totalmente contabilizada, apenas metade da "renda rural", proveniente de atividades na propriedade do agricultor, é válida.

A gente entende que o agricultor familiar deve explorar a área com a família, mas não necessariamente em período integral. A maior parte do tempo daquela família deve estar vinculada ao estabelecimento, mas os integrantes podem ter outras atividades extra-rurais (Fábio Pinto, 2011, STR-MC).

Isso abre o debate para a discussão de se o PNPB e o PAA representam o aumento da autonomia dos agricultores familiares em relação à influência de outros 
atores de mercado ou apenas a inserção gradual da categoria dentro da sociedade de consumo numa escala mais ampliada.

De antemão, é importante considerar que um dos únicos fatores que representam poder para os agricultores familiares é a propriedade da terra. Ao contrário, como fora visto, a migração é a perspectiva menos desesperadora. Sem a propriedade da terra e sem dinheiro para pagar o arrendamento da terra é raro o agricultor que tem o poder de escolher o que vai plantar.

Conforme visto por meio dos efeitos econômicos e também políticos dos programas públicos analisados em Morro do Chapéu, a expectativa de mudança social para uma situação mais alentadora é maior quando além da propriedade, há existência de formas de organização social. "O espaço social, delimitado e apropriado politicamente enquanto território de um grupo, é suporte material da existência e, mais ou menos fortemente, catalisador cultural-simbólico - e, nessa qualidade, indispensável fator de autonomia" (SOUZA, 2011, p. 107).

Ainda assim, é importante considerar que mesmo com a articulação social e o envolvimento de movimentos, como o sindical, como aconteceu para a implementação do PNPB e o PAA em Morro do Chapéu, as alterações, as rupturas promovidas pelo "efeito cumulativo complexo" (SOUZA, 2011, p. 108) em dado espaço dependem de outra série de fatores para se tornarem representativas.

a questão do desenvolvimento, mesmo quando balizada pela plena autonomia como horizonte essencial (e longínquo), se apresenta, sob a forma de pequenos e grandes desafios, quotidianamente e nas mais diferentes escalas, das mais modestas às menos acanhadas (SOUZA, 2011, p. 108).

Apesar dos indícios de que o aumento da renda e do nível de emprego por meio dos programas públicos tenham gerado, em alguns casos, a independência financeira ${ }^{50}$ de agricultores em Morro do Chapéu, a rede de relações que envolvem a principal cultura motivadora das mudanças - a mamona -, dificulta a previsão do futuro da iniciativa. Dada a instabilidade de perspectivas, é possível considerar que, até agora, a "autonomia" da categoria da agricultura familiar na escala local, possivelmente, sofreu

\footnotetext{
${ }^{50} \mathrm{O}$ agricultor Jaílson Rosa Rodrigues afirma que deixou a situação de miséria para se tornar pobre após o programa do biodiesel e que o mesmo teria acontecido com os vizinhos que trabalham com a mamona. "A nossa independência foi o biodiesel, agora todo mundo planta. Todo mundo trabalha para si próprio. Antigamente nós éramos escravos. Quando não estava trabalhando para você tinha que angariar diária, tinha que trabalhar para o outro, para os chefões. Trabalhar o dia todo parecendo um escravo" (Jaílson Rosa Rodrigues, 2011, propriedade do entrevistado).
} 
apenas uma transformação por conta de dinâmicas do "regime de classes" (FERNANDES, 2008, p. 69) que ocorreram em escala nacional.

Considerando que a lógica econômica do "capitalismo dependente" brasileiro “interfere e restringe, normalmente” (FERNANDES, 2008, p. 74), as funções do regime de classes - neste caso, da classe do campesinato - e que a "articulação de estruturas arcaicas e modernas", junto com a "modernização do campo" (FERNANDES, 2008, p. 72), são requisitos do capitalismo dependente, o que pode ter ocorrido em Morro do Chapéu após 2007 foi a melhoria das condições de vida, por conta do aumento do emprego e da renda. No plano da "constituição das condições apropriadas ao funcionamento e desenvolvimento de uma economia fundada na apropriação privada dos meios de produção, na mercantilização do trabalho e na organização das relações de produção e do mercado" (FERNANDES, 2008, p. 73), é possível considerar que:

ao pressionar as estruturas sociais preexistentes, o regime de classes tende a transformar ou eliminar formas de concentração social da renda, do prestígio e do poder típicas de sociedades estratificadas estatalmente. O que significa que essa pressão tende concomitantemente a alterar a posição relativa dos estratos baixos $^{51}$, melhorando, elevando e intensificando os níveis dentro dos quais eles participam da renda, do prestígio social e do poder (FERNANDES, 2008, p. 69).

Assim, é possível afirmar que os efeitos do PNPB em Morro do Chapéu atingiram uma escala de influência maior do que aquela alcançada pelo PAA. Apesar da comparação dos efeitos dos programas para o contexto político local ter aspectos mais difusos, por conta da influência da ação de outros atores, como o STR-MC, a comparação dos efeitos econômicos torna mais nítida a relação. O próprio presidente do STR-MC avalia que os efeitos do PNPB tornaram o impacto do programa no município mais "forte" (Fábio Pinto, 2011, no STR-MC) que o do PAA.

Apesar disso, o PAA parece interferir menos na autonomia de agricultores do que o PNPB. Enquanto a dedicação a este tem potencial de prejudicar até a segurança alimentar dos agricultores, no caso de ampla ocupação da mamona e produção escassa, o PAA apenas garante a venda de produtos tradicionais da cultura sertaneja no município a preços considerados justos. Ambos, por outro lado, favoreceram a articulação de organizações sociais.

\footnotetext{
${ }^{51}$ Formados pela "classe baixa urbana, a classe dependente urbana e o campesinato" (FERNANDES, 2009, p.70).
} 
Considerando que o maior fator de poder para o agricultor familiar é exatamente a posse, a propriedade da terra, aqueles trabalhadores que não têm poder sobre algum espaço rural estão sujeitos a muito mais influências e incertezas. Mesmo aqueles que podem escolher o que plantar sem oferecer parte da produção ou algum rendimento ao proprietário da terra, são influenciados por iniciativas como os programas públicos, que favorecem algumas culturas em detrimento de outras.

\subsection{Subsistência e perspectivas em Morro do Chapéu}

Admitindo-se as informações destacadas nos tópicos precedentes, é possível afirmar que mesmo os agricultores que possuem a posse da terra em Morro do Chapéu não têm garantias plenas de que a renda obtida com a produção rural atenderá plenamente as necessidades familiares. $\mathrm{O}$ fator climático e a assistência técnica, por exemplo, influenciam diretamente o sucesso das safras. Fontes de rendas adicionais contribuem para garantir a presença de parte da população na zona rural. Entre as mais comuns estão os programas públicos de transferência de renda e as aposentadorias.

O agricultor Jaílson Rosa Rodrigues ressalta a diferença entre os efeitos do PNPB na localidade de Malhada de Areia e os do Bolsa Família, um dos programas de transferência de renda mais influentes para a região.

\footnotetext{
Eu agradeço ao Bolsa Família, mas eu acho que não é 1\%. Não dá pra resolver nosso problema não. Veja bem, as maiores famílias aqui ganham $\mathrm{R} \$ 120$ por mês. Como vai pagar alimentação, educação, transporte, saúde e remédio? Com a mamona você garante isso. Se você adoecer, ao invés de gastar os R\$ 120 para a alimentação você vende 10 sacas que dá $\mathrm{R} \$ 900$. O nosso sucesso é por causa do biodiesel. O Bolsa Família foi bom, alguma coisa, mas não deu independência para o produtor (Jaílson Rosa Rodrigues, 2011, propriedade do agricultor).
}

As relações financeiras estabelecidas por meio dos pagamentos de benefícios em agências bancárias e postos de atendimento nas sedes dos municípios promovem a intensificação do fluxo de pessoas, mercadorias e veículos e, ao necessário, a melhoria das condições de circulação. Do mesmo modo, as aposentadorias são um dos principais benefícios sociais que garantem a existência humana no sertão. Em meados de 2011, por exemplo, sem chuvas, Rosemiro José da Silva dependia financeiramente da aposentadoria. 


\begin{abstract}
Agora, você está vendo esta roça aqui? Como nós podemos dizer que estamos sobrevivendo desta roça? Eu estou vivendo é de aposentadoria. Eu e quem é aposentado. Quem não é está sofrendo. O meu filho não é, mas se vira de segunda a domingo. Tem rocinha. No ano passado ele passou folgado, tinha o comercinho dele, tinha muita mamona, plantou feijão. Deu para sobreviver e ainda ajudar alguns. Neste ano, para ele sobreviver, não ganha um dia de serviço, mas tem que trabalhar muito, de segunda a sexta-feira. Tem que vender o leite de dia de semana, tem que trabalhar para aqui, para acolá, vender um bode, uma criação. E os outros coitados? Eu aqui não tenho precisão de pagar um trabalhador porque a renda não está dando e a roça não é suficiente. Só tem muito trabalho quando chove, que tem muita lavoura (Rosemiro José da Silva, 2011, propriedade do entrevistado).
\end{abstract}

Sete meses depois o agricultor estimava em $\mathrm{R} \$ 800$ a renda vinda da propriedade rural obtida entre setembro de 2011, quando Rosemiro iniciou o preparo do solo, até o final de fevereiro de 2012, à custa de trabalho "sol a sol” (Rosemiro José da Silva, 2012, residência do entrevistado). O valor representava as oito sacas de feijão reservadas na sala da casa do agricultor. "Esse [feijão] aí está baratinho agora, está sem preço" (Rosemiro José da Silva, 2012, residência do entrevistado).

No exemplo de Rosemiro é possível verificar que ao contrário da mamona, o feijão não teve a forma de armazenamento alterada nos últimos anos. De acordo com o presidente do STR-MC, antes do PNPB, enquanto a mamona era vendida para prover o consumo semanal, o volume da produção de outras culturas das roças, a exemplo do feijão, "ficava mais reservado, guardado, estocado, ou até quando não se produzia. $\mathrm{Na}$ maioria das vezes não se produzia" (Fábio Pinto, 2012, no STR-MC).

Rosemiro afirma também contar com a ajuda financeira das filhas a quem ele e a mulher dedicaram a vida de trabalho para conseguir educar, arcando com os custos de transportes até as sedes de Várzea Nova e Morro do Chapéu e acomodação nas cidades. Para tal, o agricultor trabalhava em sua propriedade e nas de outras pessoas no mesmo dia e a esposa comercializava confecções como ambulante. "Então, eu sofri muito pra criar minha família, porque como pobre, muita gente admira dizer: eu vi um pobre trabalhar pela vida e educar as filhas" (Rosemiro José da Silva, 2011, propriedade do entrevistado).

Duas filhas de Jaílson, da Malhada de Areia, fazem faculdades em Morro do Chapéu em centros de ensino superior à distância. "Eu nunca pensei nisso porque eu não podia nem andar na feira. Com R \$ 120 [do Bolsa Família] ia dar? Ia me dar a garantia de comprar o fubá, o feijão de corda" (Jaílson Rosa Rodrigues, 2011, 
propriedade do agricultor). O agricultor dedica o recente aumento do poder de consumo ao PNPB.

João Medeiros da Silva, de Fedegosos, até 2010, antes da aposentadoria, trabalhava na roça de segunda a sábado e prestava serviço como barbeiro (Figura 4.7.1) no povoado para complementar a renda, daí ser conhecido João Barbeiro. Após passar a receber o benefício da Seguridade Social, não abandonou a tarefa e ainda passou a pagar diárias para trabalhadores lhe ajudarem na lavoura, ampliando a capacidade de produção.

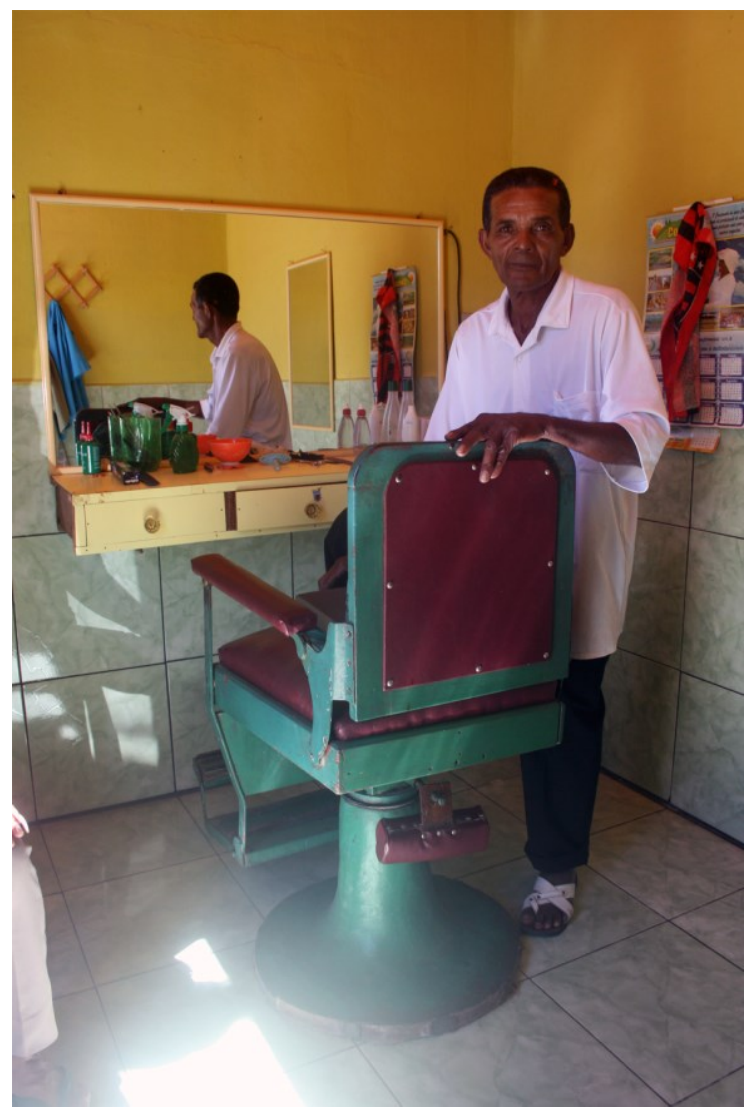

Figura 4.7.1 - O agricultor João Medeiros complementa a renda rural trabalhando no salão da barbearia que mantém em Fedegosos. Foto: Vinicius Morende, em 03/07/2011.

Outro aspecto da intensificação do meio técnico-científico-informacional no sertão baiano, especialmente nas localidades das áreas mais áridas de Morro do Chapéu, promovido pelo aumento do padrão de consumo dos agricultores, é a expansão da irrigação. Houve até a mudança de irrigantes de outras áreas da região - como do perímetro irrigado de Mirorós, em Ibipeba (BA), e do município de Lapão - para localidades próximas ao Velame, por exemplo, principalmente, nos municípios vizinhos 
de América Dourada e João Dourado. Além disso, habitantes dos locais que se beneficiaram com o aumento da renda promovido pela mamona também passaram a cobiçar a tecnologia.

\begin{abstract}
Muitas pessoas que ganham alguma coisa com a produção de mamona, principalmente, investem na perfuração de poços artesianos. Já tem algumas pessoas que irrigam, melhorando a qualidade de vida. Estão trazendo empregos diretos e indiretos para dentro da comunidade e isso eu vejo como um ponto favorável porque é a manutenção da família no campo, na sua propriedade e a possibilidade de expandir outras culturas também. Por que antes da mamona não se tinha. É por isso que eu digo, foi a mamona? É? Não. Foi a mamona e vai ser a mamona. Antes não tinha (Luciano Bernardo de Brito, 2011, propriedade do entrevistado).
\end{abstract}

A família de Lula possui uma área irrigada de mais de quatro hectares no Velame. O patriarca, seu Dezinho, no entanto, não abre mão de cultivar no esquema de sequeiro, dependente apenas dos fatores climáticos. Obviamente, entre uma forma de produção agrícola e outra há diferença considerável no aumento dos gastos financeiros dedicados. É importante considerar que parte considerável dos agricultores de diversas localidades da região não possui acesso ao crédito, principalmente, por conta do processo de endividamento bancário posterior à queda na produção do feijão, ocorrida a partir da década de 1980, dada de forma generalizada na região de Irecê.

$\mathrm{O}$ ator financeiro nesta situação, representado pelo sistema bancário, se mostrou determinante para a estagnação econômica da agricultura. Foram programas públicos de anistia concedidos a favor dos agricultores que amenizaram o problema. Neste contexto é que a mamona chega a ser considerada como uma alternativa à falta de produtividade regional do feijão.

A questão climática também se mostrou como um fator atual de desvantagem para os agricultores em relação às décadas anteriores. Isso pode ser visto até pelo desaparecimento de culturas de algumas áreas, como a cana-de-açúcar em São Rafael ${ }^{52}$, localidade que já possuiu dois engenhos.

Parece haver uma sensação em diversas localidades de que as chuvas atualmente são mais escassas que há três ou quatro décadas. Os agricultores mais velhos relacionam a influência de um clima mais chuvoso na época em que havia mais matas e árvores em Morro do Chapéu e na região (Abiderman Bernardo de Brito, 2012, residência do

\footnotetext{
${ }^{52}$ De acordo com o patriarca da família de Luciano de Brito Souza, os engenhos da fazenda a qual, supostamente, os escravos teriam deixado e formado o povoado do Velame passavam "dois, três meses moendo (cana-de-açúcar) direto. Fazia muita rapadura, mel. [...] Mas hoje não se produz mais. De sequeiro, cana não" (Abiderman Bernardo de Brito, 2012, residência do entrevistado).
} 
entrevistado; Rosemiro José da Silva, 2012, residência do entrevistado no Icó). Esta situação ajudaria a justificar o fato da mamona já ser considerada uma alternativa viável para agricultores de áreas tradicionalmente mais úmidas do município, como Fedegosos, onde também há relatos de chuvas mais escassas (João Medeiros da Silva, 2012, propriedade do entrevistado). A irrigação entra nesta dinâmica como um elemento problematizador.

De acordo com Luciano Bernardo de Brito, o Velame é uma das localidades da área da bacia do rio Jacaré, que limita a maior área da parte ocidental do território de Morro do Chapéu, nas quais a irrigação chegou em menor intensidade. Há três poços artesianos em uso em propriedades da família do agricultor e outros dois próximos. "Existem comunidades bem próximas daqui que tem poços a cada 200 metros. Comunidades menores do que o Velame que têm 20, 25 poços perfurados. De certa forma ajuda, tem o emprego, mas tem o custo, o ônus que é a falta de água no futuro" (Luciano Bernardo de Brito, 2011, propriedade do entrevistado).

De acordo com Lula a situação no início de 2012 estava "descontrolada". "Os poços estão cedendo. Daqui do lado mesmo, a seis quilômetros daqui, o colega já reclamou, que já tirou a bomba, porque não tem água. Ele sozinho tem dois poços, são três da família. Tem o vizinho, outra família. Está como tábua de pirulito" (Luciano Bernardo de Brito, 2011, residência do entrevistado). O próprio agricultor admite, no entanto, que a vontade dos agricultores familiares é manter um poço artesiano na propriedade a depender da viabilidade geográfica das áreas, das condições financeiras para arcar com o serviço ou do poder de reivindicação para perfurar um poço com o apoio do poder público. Nem que para este expediente tenha que recorrer ao auxílio de políticos e a força de organizações da sociedade civil, como as associações comunitárias e as entidades de classe, como o STR-MC.

Isso ocorreu no caso da área da Varginha, localidade rural próxima ao povoado do Icó na qual se localiza a propriedade rural da família do agricultor Zé Capoeira. No caso, a solicitação para a perfuração de dois poços com o apoio do poder público, representado pelo deputado federal Edson Pimenta, já marcados "pelo Estado" (José Barbosa de Jesus, 2012, propriedade do entrevistado no Icó) atenderia uma estimativa de cem proprietários vizinhos. Zé Capoeira já possuía dois tanques para armazenamento de água, um deles mais antigo, obtido por meio da associação comunitária do "bairro" da Varginha. 
Enquanto a evolução do transporte no município diminuiu o tempo das viagens e alterou a relação espaço-temporal, principalmente, após a melhoria das condições dos caminhos e estradas, a ampliação das redes de energia elétrica também se mostra condicionante para as dinâmicas espaciais do avanço da irrigação. Combinada com o aumento da renda dos agricultores, a irrigação se fez presente em novas localidades.

O presidente do STR-MC, Fábio Pinto defende que o avanço da irrigação deveria receber a atenção do poder público. De acordo com o sindicalista, a prática tem contribuído para a disseminação do plantio de espécies de mamona adaptadas à irrigação na região e estes fatores têm provocado a valorização das terras no município.

Ao tempo que a mamona irrigada se apresenta como uma possibilidade de renda para a agricultura familiar, caso os preços da matéria-prima se mantenham relativamente valorizados, também representa fator determinante para a territorialidade em Morro do Chapéu, especialmente para o padrão de alimentação sertanejo. Isso aconteceria por conta do estímulo à cultura agrícola em detrimento dos gêneros que garantem a abalada autonomia alimentar da agricultura familiar no sertão.

Sem assistência técnica adequada, o que requer investimento financeiro, já que o PNPB e a PBio não favorecem o cultivo da mamona irrigada, a produtividade da cultura se mostra tão instável quanto o cultivo de sequeiro. Exemplo disso foi uma associação mal sucedida da mamona com a abóbora realizada na área irrigada de Lula, agricultor do Velame. "Eu esperava ter [uma produção] em torno de 120, 150 sacas. Até agora eu não bati cinco sacas por tarefa. Foi terrível. Foi pior que de sequeiro" (Luciano Bernardo de Brito, 2012, residência do entrevistado).

Isso é, enquanto a PBio promove a intensificação da base técnica com o uso corporativo do território (PEREIRA, KAHIL, 2010, p. 295), no caso de Morro do Chapéu, por meio da mamona, a própria empresa impõe normas em relação à regulação da atividade nas localidades. Afinal, não interessa à firma se fazer envolver publicamente com o uso das reservas subterrâneas de água no semi-árido para a produção de biocombustível. Obviamente, isso não impedirá que atores como os intermediários da indústria ricinoquímica absorvam a produção de mamona irrigada.

A disseminação da irrigação compreendida como um "fenômeno técnico" nas localidades pode ser considerada ação constitutiva do "espaço geográfico" e pressupõe o estabelecimento de novas normas, na relação do estudo do "direito à geografia" (ANTAS, 2005, p. 186), que não necessariamente estão se dando na escala local. 
Posta em exercício, a norma passa efetivamente a produzir transformações e, do grau de interdependência da referida norma com o território, resultam diferentes demandas por novas normatizações, pois, uma vez alterado um contexto territorial, em seus processos e funcionamentos, novos usos se impõem, novas práticas, e consequentemente necessidades novas de regras. Esse movimento não se encerra num mecanismo simples de ação e reação (ANTAS, 2005, p. 187).

O risco ambiental promovido pela intensificação da irrigação já era formalmente reconhecido, pelo menos, desde 1997, quando um estudo do CPRM (Serviço Geológico do Brasil) recomendou cuidados relacionados aos "aspectos hidrogeológicos da área" (ROCHA, 1997, p. 122). O documento recomendava que se evitasse a perfuração de “poços [artesianos] mal localizados e construídos (Figura 4.7.2), além de sistema de abastecimento [humano] deficientes" (ROCHA, 1997, p. 122), a recuperação de poços obstruídos e a perfuração de poços em áreas carentes, "tendo em vista que mais de $80 \%$ da população não dispõe de suprimento de água superficial durante os períodos de seca" (ROCHA, 1997, p. 122).
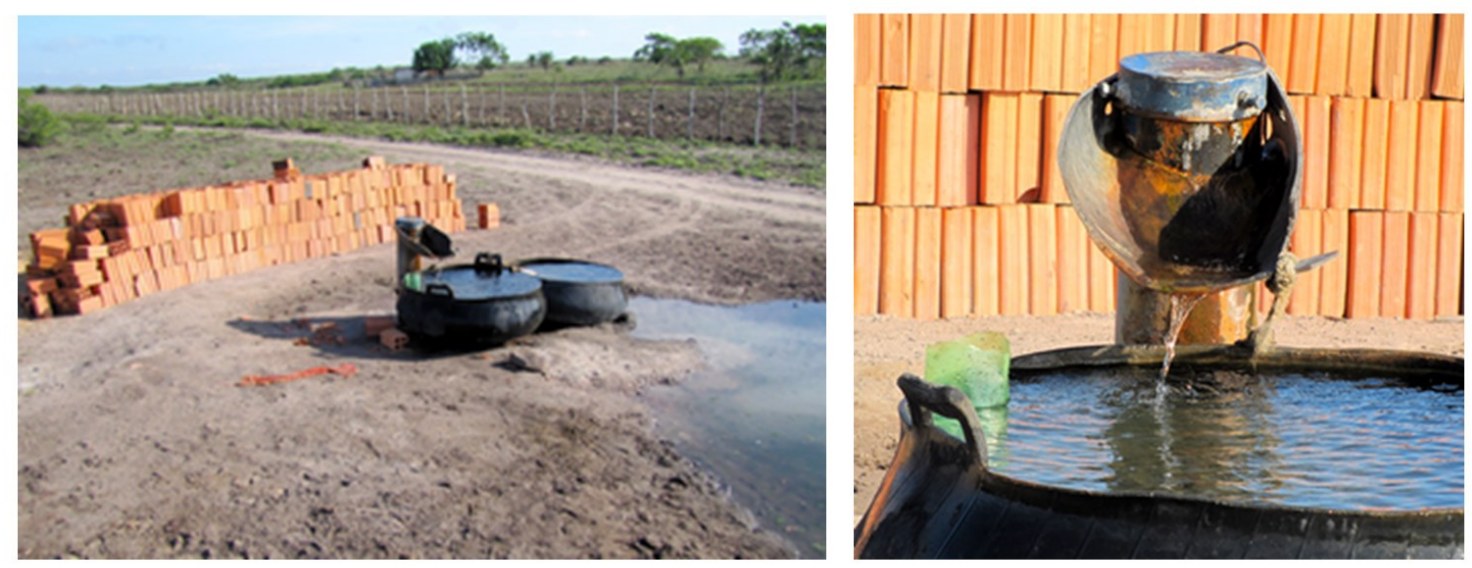

Figura 4.7.2 - Poço artesiano irregular próximo de comunidade na proximidade do PEMC, com extravasamento de recursos hídricos. Foto: ACVMC (Associação de Condutores de Visitantes de Morro do Chapéu).

Além disso, o estudo também alertava para o desmatamento desordenado, "responsável pela alteração dos processos de erosão, com assoreamento de rios e barragens, causando também a aridez e a desertificação" (ROCHA, 1997, p. 122), que já é evidente na região do antigo distrito de Caraíbas, atual Irecê, que pertencia à área da freguesia de Morro do Chapéu. 
Caso não haja a regulação do poder público frente os processos de intensificação da base técnica em localidades do sertão baiano, como aquelas próximas ao Velame, é possível que nos próximos anos estas áreas experimentem dinâmicas de retração econômica como aquelas que o antigo distrito de Caraíbas enfrentou após a decadência da produção do feijão a partir da década de 1980.

Se a intensificação da irrigação, por exemplo, não representar um processo estruturado de emergência social no sertão, baseado na estabilidade dos recursos ambientais das localidades, possivelmente, servirá apenas para que lugares como o Velame sejam utilizados até a exaustão dos recursos disponíveis, pelos interesses de atores hegemônicos, servindo ao "adversário global, concentrador e anti-democrático" (OLIVEIRA, 2001, p. 19). Portanto, não terão significado novas formas autônomas de desenvolvimento local.

Neste caso, programas públicos como o PNPB terão servido apenas para facilitar a incorporação de áreas por atores com vínculos mais estreitos com os interesses do mercado globalizado. Outro problema é que aqueles agricultores que permanecerem nessas áreas e incorporarem a intensificação da base técnica nas propriedades podem acabar perdendo as características de agricultores familiares, o que também entra em contradição com o objetivo do programa de promover o fortalecimento do campesinato.

Para evitar isso, seria necessário que o poder público federal, um dos principais responsáveis pelas dinâmicas relacionadas ao PNPB na escala local, atuasse a favor do fortalecimento da agricultura familiar em aspectos que não foram suficientemente considerados até então, como o apoio à diversificação da produção, uma característica histórica da categoria. A intensificação das atividades de programas como o PAA e o PNAE (Programa Nacional de Alimentação Escolar) e o desenvolvimento de outros programas relacionados ao fortalecimento das cadeias produtivas de diversos gêneros agropecuários poderia representar também um maior poder de influência dos pequenos agricultores sobre os territórios nos quais vivem.

Do mesmo modo, seria exigido um maior poder de organização dos agricultores, com a criação de novas organizações de comercialização e representação ou o fortalecimento das já existentes, com o devido acompanhamento e assistência necessária por parte do poder público. Este parece ser um dos modos de fazer a agricultura familiar nas localidades equilibrar a disputa frente aos atores de mercado globalizados do setor agropecuário e ao agronegócio e tornar mais balanceados os efeitos de iniciativas como a do próprio PNPB. 


\section{Considerações finais}

A partir das informações apuradas este estudo verificou como e em quais dimensões se deram as contradições geradas por meio do Programa Nacional de Uso e Produção do Biodiesel (PNPB) e do Programa de Aquisição de Alimentos (PAA) no município de Morro do Chapéu. Buscou-se também relacionar o espaço de atuação das iniciativas às esferas nacional e internacional de influência, evidenciando as relações entre a escala local e a realidade cada vez mais globalizada. A apresentação das comunidades e povoados visitados de Morro do Chapéu, no entanto, não expõe apenas condições de existência específicas dos locais, mas sim um padrão de vida inerente ao município, à região e, talvez, ao semi-árido brasileiro.

Para que isso pudesse acontecer foi necessário dar voz aos habitantes destas localidades e valorizar histórias, discursos e significados. As citações dos entrevistados, no entanto, foram tratadas não como opiniões individuais, mas sim discursos que se desenvolveram a partir de experiências coletivas, no caso, na maior parte, relacionadas à produção de gêneros agrícolas para atender ao PNPB ou o PAA.

Estas informações, junto com aquelas obtidas por meio de levantamentos bibliográficos, foram relacionadas a categorias analíticas socioespaciais para desvendar a formação territorial do município ao longo dos séculos e durante o processo em destaque. Para tanto, uma série de ações que caracterizaram a ocupação sertaneja, como a passagem de colonizadores, o desenvolvimento da pecuária, da agricultura, $o$ surgimento das fazendas, os fluxos de escravos, o apogeu e declínio da mineração de pedras preciosas, entre outros, foram considerados. Os processos relacionados a estas atividades ainda marcam a estrutura social local e, neste sentido, influenciam novas ações como as do PNPB e PAA.

A compreensão da influência da pecuária, mineração e agricultura contribuiu para a avaliação de como as formas espaciais de Morro do Chapéu foram modificadas ao longo dos séculos até hoje. Estas atividades ajudaram a explicar, por exemplo, como os vastos tabuleiros do município se transformaram em propriedades particulares, como o cerco de pequenas áreas para o encurralamento de animais deu lugar às cercas dividindo terras de diferentes donos e como porteiras passaram a cruzar trilhas e caminhos antes contínuos. 
O exercício de organização dos processos de formação territorial do município abrangeu, principalmente, as áreas rural e urbana, mas também considerou as sedes das cidades vizinhas, entre elas aquelas que se emanciparam a partir da antiga área da freguesia de Morro do Chapéu. Foram verificadas territorialidades destes lugares e como a mamona, de uma condição de cultura agrícola secundária, se transformou na principal fonte de renda de algumas localidades.

A Cooperativa de Produção e Comercialização da Agricultura Familiar do Estado da Bahia (Coopaf), na função de executora das atividades do PNPB e do PAA em Morro do Chapéu, a partir das iniciativas, promoveu novas dinâmicas nas esferas econômica, política e social no município. As mudanças integraram o processo de intensificação da ação pública federal e a evolução da infraestrutura em escala regional ocorridos, principalmente, na última década.

A análise de algumas etapas da construção do poder formal na escala local ajudou a verificar as reminiscências de processos históricos na estrutura política no período entre 2007 e 2012, quando ocorre o fortalecimento dos conceitos associativista e cooperativista após a emergência das ações do PNPB e do PAA. As relações entre as escalas municipal, estadual e federal de poder, a emergência de associações que representam as comunidades tradicionais e os moradores de localidades e o poder de organização dos trabalhadores rurais por meio do movimento sindical também se traduziram de variadas maneiras na esfera local.

A ascensão de um novo grupo político apoiado na expansão da capacidade de atração de recursos financeiros da Coopaf provocou novas dinâmicas dentro da estrutura política do município. É possível visualizar isso na análise dos resultados apurados em seções eleitorais de Morro do Chapéu nos pleitos realizados entre 2008 e 2012. Algumas localidades do município onde a atuação da cooperativa e do movimento sindical se deu com maior intensidade foram importantes para a eleição de representantes ligados a ambas as instituições à câmara de vereadores municipal.

Uma análise sobre a importância da comunicação e da circulação das informações na escala local, o uso político dos meios de comunicação e manipulação do eleitorado, baseada, em especial, na invasão de uma rádio comercial de Morro do Chapéu por um grupo de militantes de um grupo político, acontecimento de repercussão nacional, ajudam a compreender a situação política do município.

A análise de dados do Instituto Brasileiro de Geografia e Estatística (IBGE) fundamentou os relatos de agricultores familiares de que o PNPB teria produzido um 
processo de valorização financeira da mamona no período, processo que se intensificou com a criação e a entrada da Petrobras Biocombustíveis (PBio) no mercado. Isso teria provocado também a expansão da ocupação e da influência da cultura em diversas localidades de Morro do Chapéu e da região. A mamona deixou de servir apenas aos produtores situados nas caatingas do município, por conta da adaptação histórica ao clima semi-árido e à baixa pluviosidade, e passou a ocupar espaços mais amplos em propriedades da zona mais úmida de Morro do Chapéu.

A análise permitiu refletir sobre a importância dos atores e forças que influenciam o mercado da mamona e quais as perspectivas da cultura dentro das dinâmicas do programa do biodiesel. Além do papel exercido pela PBio, a função dos atravessadores, representados por uma extensa rede de negociantes na escala local, também foi relacionada ao histórico de produção e de variação dos preços da saca da mamona em Morro do Chapéu.

Do mesmo modo ocorreram mudanças motivadas pelo PAA no município, como o incentivo à produção de gêneros agrícolas, o aumento na renda de famílias e o aumento do valor de algumas culturas. Foi possível relacionar os efeitos promovidos pelo programa em relação àqueles do PNPB a partir da diferença entre as escalas de ação de ambos.

Entre 2007 e 2012, a circulação de pessoas e mercadorias entre a zona rural e a sede do município baiano também passou por um processo de intensificação, influenciada pelos programas públicos citados. A dinamização dos fluxos em Morro do Chapéu é baseada no crescimento da renda de agricultores e das relações financeiras, principalmente, aquelas motivadas pelos programas públicos, entre eles o PNPB e o PAA. A melhoria das condições de negociação fez a mamona se tornar a principal geradora de empregos no município no período analisado e provocou alterações nas relações de trabalho e no padrão de armazenamento e comercialização da cultura.

O estudo revelou ainda que a maior inserção da agricultura familiar na lógica capitalista promoveu também dinâmicas relacionadas à mecanização da produção. Do mesmo modo, a expansão da eletrificação na zona rural do município favoreceu a intensificação da perfuração de poços artesianos e a ampliação das áreas irrigadas. As restrições hídricas históricas provocadas por prolongados períodos de estiagem em algumas localidades e o risco ambiental por conta do uso extensivo dos lençóis freáticos expuseram uma das contradições dos efeitos provocados pelos programas públicos em Morro do Chapéu. 
Por outro lado, a evolução dos modos de obter renda, o aumento do emprego e do volume de trabalho também pode ter favorecido a maior de fixação do homem no campo. A função da agricultura familiar de promover a evolução social de comunidades da zona rural de Morro do Chapéu, provavelmente, apresentou condições mais favoráveis a partir do período de influência dos programas públicos. No entanto, outra contradição deste processo, destacado nesse trabalho, foi o desaparecimento gradual de áreas em repouso e a impossibilidade de realizar a rotação de solo, um dos principais fatores que promoveram a queda da produção de outras culturas na região na qual o município está inserido.

As dinâmicas analisadas entre 2007 e 2012 também podem provocar a redução da margem de ação da própria agricultura familiar. Os pequenos produtores podem deixar de serem enquadrados neste conceito e de serem beneficiados pelos programas públicos a partir do maior envolvimento de integrantes das famílias em atividades extra rurais, como o aluguel de tratores ou a operação de maquinário agrícola. Além de verificar a melhoria das condições de renda e de vida dos agricultores, a análise permitiu também a reflexão sobre a influência das ações promovidas pelo governo federal em relação à conquista de autonomia pelos agricultores familiares.

Finalmente, este estudo procurou apresentar, sem querer esgotar o assunto, a complexa relação entre a intensificação da base técnica, as características naturais no sertão nordestino brasileiro e a autonomia da agricultura familiar. A partir da realidade exposta em Morro do Chapéu é possível afirmar que o aumento da renda de agricultores familiares que possuem acesso e a propriedade da terra, cooperados a partir do cultivo da mamona, trouxe como conseqüência a mecanização da produção e o aumento das áreas irrigadas por poços artesianos. Esses fatores foram alavancados, principalmente, pelo Programa Nacional de Produção e Uso do Biodiesel (PNPB). Ao lado do Programa de Aquisição de Alimentos (PAA), o PNPB foi o principal responsável pela dinamização das atividades socioeconômicas na área estudada.

Da mesma forma que esta dinamização exigiu a regulação por meio de normas, ditadas tanto pelo Estado como pelo mercado, a fim de controlar as atividades dentro de um padrão de crescimento adaptável ao semi-árido, expôs a necessidade de geração de novas normas de regulação. A intensificação do uso de recursos hídricos de forma exaustiva no semi-árido exige até mesmo a necessidade de estudos da capacidade do meio em prover o novo padrão de demanda hídrica. $\mathrm{O}$ atendimento das exigências tem 
caráter de urgência no caso de uma região que enfrenta a desertificação de territórios antes produtivos.

Ao mesmo tempo, a imprevisibilidade de sustentação do modo de produção da agricultura familiar na região, sobretudo por conta da habilidade do camponês do sertão nordestino em se adaptar às mudanças das circunstâncias em Morro do Chapéu, e mesmo com a intensificação da base técnica do sertão, sugere que se deva garantir a permanência do incentivo de programas como o PNPB e o PAA. Isso porque, embora estes programas não tenham feito o agricultor desenvolver um grau de autonomia que o tornasse independente do apoio do poder público federal, promoveram níveis de renda nunca antes conquistados.

Contudo, as atuais regras para a concessão da Declaração de Aptidão ao Pronaf (DAP) e a restrição ao desenvolvimento econômico das famílias de agricultores a partir de atividades relacionadas ao meio rural representam riscos para o desenvolvimento em algumas comunidades. Sem o apoio do governo federal qualquer nova função destinada às localidades, por qualquer ator, pode representar alterações naquilo que é o principal poder do agricultor familiar: a propriedade da terra.

Consequentemente, tal fato pode contribuir para alterações nas diversas localidades, principalmente ligadas ao êxodo rural, por meio das migrações temporárias ou definitivas. Isso pode tanto acontecer de maneira legal, a partir da decadência de funções econômicas, quanto ilegal, como é possível verificar em diversos casos da formação territorial de municípios como Morro do Chapéu.

Especificamente em relação ao PNPB, pelos dados apresentados, conclui-se que a finalidade dos biocombustíveis está associada ao mercado especulativo da economia capitalista, já que a mamona não é um substitutivo do petróleo, mas um complemento desta fonte de energia. Com isso, a função do programa como um motivador da evolução das bases sociais da agricultura familiar se torna questionável. A partir das informações apuradas neste trabalho, é possível inferir que a principal característica do PNPB seria a de um programa de capitalização ao invés de econômico ou social.

Assim, o apoio à produção da mamona pelo governo federal estaria de acordo com o processo histórico de investimento estatal nas culturas de interesse do setor industrial, como já demonstrado por outros pesquisadores ${ }^{53}$. Este aspecto estaria em contradição em relação ao objetivo do programa de favorecer a agricultura familiar. Além disso, apesar dos benefícios financeiros dos agricultores, obtidos com a

\footnotetext{
53 Veja por exemplo SUZUKI, 2007, p.93.
} 
valorização da mamona, é possível verificar que atores do capital comercial e industrial, entre eles, os atravessadores e a própria Petrobras Biocombustíveis (PBio), aproveitamse do PNPB para fazer o uso corporativo dos territórios, das culturas utilizadas para a produção de biodiesel, entre elas, a mamona.

Isso não acontece com o PAA, por exemplo, apesar de ser evidente a diferença entre os efeitos financeiros do programa em relação ao PNPB. O próprio volume de recursos administrados pela Coopaf voltados para o programa do biodiesel foi muito maior que aqueles destinados ao PAA. A diferença entre o tempo de execução das atividades de cada programa no município, exposta pelos períodos nos quais a cooperativa operou os contratos de um programa e de outro, é outra evidência de que o poder público federal oferecia mais atrativos à execução do PNPB do que do PAA em Morro do Chapéu.

Assim, o PAA exerceu uma influência menor sobre a estrutura do município do que o PNPB em Morro do Chapéu. Obviamente, deve ser considerado que a comparação neste caso é de um programa em relação a uma atividade de outro programa, no caso, o Fome Zero, concentrador de uma série de outras ações que se deram no sertão baiano.

Do mesmo modo que o incentivo à produção de alimentos pelo PAA não representou grandes volumes de ganhos financeiros para os participantes da iniciativa no município, também não representou a perspectiva de perda de autonomia dos agricultores. Ao contrário do que pode acontecer a partir dos investimentos em parte da agricultura familiar por meio do PNPB, da intensificação da base técnica em localidades da zona rural do município e da conseqüente pressão sobre o limite de renda extra-rural que caracterizaria o produtor como agricultor familiar.

Uma das soluções para este problema exige maiores níveis de organização dos trabalhadores e de representatividade da agricultura familiar dentro das esferas decisórias do governo federal relacionadas às questões rurais abordadas, especialmente, do PNPB e do PAA. Da mesma forma, é exigida a maior participação da agricultura familiar como ator decisório dentro da lógica de mercado da cultura da mamona. Para isso, seria necessário o controle maior dos trabalhadores sobre a produção, maior capacidade de armazenamento, o controle sobre os estoques, a negociação direta com as indústrias processadoras do óleo e maior influência sobre a definição dos preços do produto. 
Do contrário, a sojicultura continuará dominando quase que totalmente a produção de biodiesel e a expansão da sua produção impedirá o avanço de outras culturas dentro e fora do PNPB, resultando numa homogeneização de paisagens, representada pela monocultura da soja. Nessa situação, cada vez mais áreas de Estados como a Bahia deverão ser ocupadas por grandes fazendas de soja. O problema não só envolve a questão da destinação de gêneros alimentícios para a produção de combustível, como também o incentivo a este tipo de negócio em regiões nas quais muitas comunidades ainda sofrem com a falta de segurança alimentar. São dinâmicas completamente opostas ao objetivo do programa de beneficiar a agricultura familiar.

A partir dos efeitos de ambos os programas apresentados nesta pesquisa, tornase importante debruçar-se sobre alguns aspectos, entre eles a importância da mamona dentro da lógica do PNPB. Afinal, se a alta no preço da cultura é o principal fator que inviabilizaria o uso do óleo de mamona no programa público, esta também é uma questão de mercado. Assim, ampliando a produtividade e a produção seria possível reduzir o preço do óleo.

Os principais atores a serem envolvidos para solucionar esta equação são a PBio e os trabalhadores da agricultura familiar. Assim, o PNPB poderia fazer sua função social em Morro do Chapéu e os trabalhadores teriam consolidadas as perspectivas de aumento da renda. Além disso, o óleo de mamona poderia ser inserido no portfólio de produtos da PBio, empresa integrante do maior grupo brasileiro fabricante e distribuidor de combustíveis e lubrificantes. A própria firma utiliza o lubrificante oriundo da oleaginosa na prospecção de poços de extração de petróleo em grandes profundidades em plataformas marítimas.

Obviamente, repensar a lógica do uso de diferentes culturas agrícolas para o PNPB exigiria a elaboração de um novo marco regulatório para o biodiesel. As regras deveriam levar em conta a continuidade da orientação de apoio à agricultura familiar e à produção de mamona no Nordeste. O principal fator que deveria garantir essas características são os próprios efeitos sociais obtidos pelo programa em municípios como Morro do Chapéu.

Da mesma forma, as mudanças promovidas por conta do PAA, mesmo não tendo sido determinantes para o aumento da renda ou a intensificação técnica no município baiano, produziram dinâmicas que contribuíram diretamente para a valorização de diversas culturas agrícolas e a melhoria das condições de vida do 
agricultor familiar, sem representar riscos ao retrocesso das condições de existência do campesinato.

Para intensificar este processo seriam exigidos maiores investimentos públicos em benefício das diversas culturas agropecuárias tradicionais do sertão baiano e das referidas cadeias produtivas, a partir da evolução do modo de vida da agricultura familiar. Além de incentivar a organização do campesinato para tanto, seria necessário também destinar mais recursos ao desenvolvimento científico, técnico e informacional de cada uma destas culturas.

Seria possível até mesmo estimular a regulação para a atração de investimentos privados para tanto, desde que as práticas do comércio justo fossem respeitadas, a fim de minimizar, principalmente, a desigualdade de ganhos dos agricultores em relação a outros atores das cadeias de alguns produtos. Nesta perspectiva, também seria necessário que o poder público solucionasse as distorções nas normas de enquadramento da agricultura familiar dentro do padrão estabelecido para a concessão da Declaração de Aptidão ao Pronaf (DAP), especialmente aqueles fatores relacionados à obtenção da renda extra-rural.

A experiência do PNPB e do PAA em Morro do Chapéu permite considerar que a organização das cadeias tradicionais da região também permitiria reduzir o desequilíbrio entre os ganhos financeiros do produtor, dos intermediários e das indústrias processadoras do produto final, um dos principais fatores de desvantagem dos agricultores familiares na atual lógica de mercado. Neste caso, o investimento público na capacitação do potencial agroindustrial para a agricultura familiar, por exemplo, poderia representar outro fator de empoderamento do camponês.

É necessário investir, então, na valorização da produção em geral das localidades, criando condições melhores de remuneração para o agricultor. Do mesmo modo que o agronegócio e as principais safras recebem financiamentos e incentivos do governo, este deveria dar melhores condições para o cultivo em localidades como as do sertão baiano, ao invés de incentivar o cultivo de novas áreas do Estado pela soja, por exemplo. $\mathrm{Na}$ verdade, seria mais aceitável o apoio público ao desenvolvimento da agricultura familiar do que a um ator como o agronegócio, que possui um nível maior de autonomia financeira e influência política consolidada.

O PAA não é a solução para os problemas da agricultura familiar, assim como não o foi o Fome Zero. No entanto, é inegável que ambos tenham trazido benefícios para a melhoria das condições de vida de uma categoria que representa sérios desafios 
para a administração pública. Estes desafios se dão tanto pela situação de vulnerabilidade social em que este ator se encontra, quanto pelo potencial de seu fortalecimento evidenciar alternativas às limitações do atual modelo hegemônico de desenvolvimento do meio rural, relacionado ao avanço do consumo e do modo de produção capitalista de base intensiva.

Se a organização do agricultor for realizada efetivamente a partir das bases cooperativista e associativista será menor o potencial de exposição do agricultor familiar às influências do ator hegemônico representado pelo mercado cada vez mais globalizado. Consequentemente, haveria maior possibilidade de surgirem novas formas e funções para o espaço geográfico a partir das demandas do próprio local. Mesmo se o incentivo às novas dinâmicas viesse de outros lugares, as garantias provindas da propriedade da terra e a menor exposição às privações econômicas e sociais colocariam o agricultor numa situação mais confortável para definir seu destino.

A importância dada à participação do poder público nestes processos se dá justamente por conta da relevância dos governos federais, estaduais e municipais nos processos de formação territorial de áreas como Morro do Chapéu. Seja pela presença ou pela ausência da ação do poder público, a realidade a que está exposta a sociedade do lugar, de uma maneira geral, também é responsabilidade do ator público. Se este continua influenciando a formação territorial, deve ser orientado à realização de práticas mais adequadas às condições de existência humana no semi-árido.

Os atores mais vinculados às localidades, os agricultores que possuem a propriedade da terra, precisam ser mais envolvidos na tomada de decisões destes atores. Do contrário, a influência externa, seja ela regional ou internacional, ainda mais distante da realidade do local, pode se fazer hegemônica para as dinâmicas do território. A imposição de dinâmicas por atores alheios às condições de vida dos lugares, sejam vinculados ao Estado ou ao mercado global, pode significar prejuízos sociais e ambientais irreparáveis.

Torna-se importante refletir sobre as dinâmicas futuras dos programas públicos analisados em uma realidade em que o contexto global está cada vez mais presente nas localidades. Isso é visível em municípios aparentemente marcados por formas que evidenciam funções que pertencem a séculos passados, como é o caso da pecuária e da mineração em Morro do Chapéu.

Isso porque a emersão de novas formas e funções espaciais no município baiano parece ocorrer numa dinâmica cada vez maior de diferenciação espacial, ao invés de 
homogeneização do espaço. Isso é, ao invés de promover a inclusão da região de Morro do Chapéu em novas dinâmicas tecnológicas, com a devida atenção aos preceitos debatidos pelos movimentos ambientais transnacionais, a globalização tem aproveitado as características particulares de localidades de Morro do Chapéu para redefinir os interesses econômicos a partir de seus valores, fazendo-os pelo nível local e determinando as normas de uso dos lugares.

A força das dinâmicas do modo de produção capitalista e a forma como este se adapta à emergência de discursos como os do desenvolvimento sustentável, responsável pela criação de novas demandas e normas, pode ser visto em Morro do Chapéu na emergência de uma nova função econômica destinada às localidades situadas nas áreas mais altas do município. Esta função se dá a partir do interesse de empresas transnacionais e tem como objetivo a expansão das atividades relacionadas à energia eólica, não discutida neste trabalho.

Esta função parece representar um novo advento do meio técnico-científicoinformacional para a escala local, também incentivada pelo aumento da demanda por novas fontes de energia menos poluidoras. Aparentemente, a força dos atores que atuam em favor da energia eólica, cuja influência em Morro do Chapéu também se deu, principalmente, a partir do ano de 2007, parece ser mais eficiente em produzir dinâmicas e mudanças no território do que qualquer outro programa público.

Tento em vista o surgimento de novas dinâmicas no espaço de Morro do Chapéu e a experiência obtida pela Coopaf no município a partir do PNPB e do PAA também é relevante considerar que a falta de incorporação dos conceitos ideais de funcionamento de organizações cooperativistas faz com que estas acabem exercendo a mesma função de qualquer outro ator de mercado. É possível considerar que a atuação daquela cooperativa está de acordo com as organizações do gênero nas quais os principais beneficiados são os grupos internos de indivíduos que manifestam maior desenvoltura no relacionamento com as variadas esferas de poder e na gestão dos contratos de negócios ou de prestação de serviços.

A limitação do sucesso do caso de Morro do Chapéu é um exemplo da necessidade de empoderar as bases com maior representatividade na tomada de decisões, principalmente aquelas relacionadas aos investimentos realizados e à administração dos grupos. Do contrário, os cooperados alheios à burocracia administrativa ficam ainda mais expostos ao risco do endividamento financeiro. 
Historicamente, este panorama promove situações de vulnerabilidade social no campo e restrição dos agricultores em relação à participação em novas propostas de organização. 


\section{Referências bibliográficas:}

AB'SABER, A. N. et al. A época colonial. 14. ed. Rio de Janeiro: Bertrand Brasil, 2011. v. 2: Administração, Economia, Sociedade.

AGNEW, J. Mastering space: hegemony, territory and international political economy. New York: Taylor \& Francis e-Library, 2003.

, J. Geopolitics: re-visioning world politics. 2nd ed. New York: Taylor \& Francis e-Library, 2004.

ANDRADE, M. C. A terra e o homem no Nordeste: contribuição ao estudo da questão agrária no Nordeste. 6. ed. Recife: Editora Universitária da UFPE, 1998.

ANTAS JR., R. M. Território e regulação: espaço geográfico, fonte material e nãoformal do direito. São Paulo: Associação Editorial Humanitas/Fapesp, 2005.

ANTONIL, A. J. Cultura e opulência do Brasil. 3. ed. Belo Horizonte: Itatiaia/Edusp, 1982. (Coleção Reconquista do Brasil)

ARAÚJO, J. P. (org.). Um retrato do Brasil: balanço do governo Lula. 1. ed. São Paulo: Editora Fundação Perseu Abramo, 2006. (Coleção Brasil urgente)

BAHIA (Estado). Conselho Estadual de Desenvolvimento Social. Resolução Cedeter $\mathrm{n}^{\mathrm{o}}$ 3 de 25 de fevereiro de 2011. Dispõe sobre a normatização e critérios para reconfiguração dos limites e toponímias dos Territórios de Identidade do Estado da Bahia, estabelecidos na Lei $\mathrm{n}^{\mathrm{o}} 10.705$ de 14 de novembro de 2007. Diário Oficial do Estado, Salvador, BA, 26 e 27 fev. 2011.

BANDEIRA, R. L. S. B. Chapada Diamantina, história, riquezas e encantos. 2. ed. Salvador: Onavlis Editora, 1997.

BECKER, B. K. A Geopolítica na Virada do Milênio: Logística e Desenvolvimento Sustentável. In: CASTRO, I. E., GOMES, P. C. C.; CORREAA, R. L. (org.). Geografia: Conceitos e Temas. 14. ed. Rio de Janeiro: Bertrand Brasil, 2011, p. 271-306. 
BRASIL. Ministério Extraordinário para a Coordenação dos Organismos Regionais. I Plano Diretor de Desenvolvimento Econômico e Social do Nordeste 1961-1963. Recife: Sudene, 1966.

Conselho de Desenvolvimento: Grupo de Trabalho para o Desenvolvimento do Nordeste. Uma política de desenvolvimento econômico para o nordeste. 2. ed. Recife: Sudene, 1967.

Casa Civil. Lei $\mathrm{n}^{\circ} 11.097$, de 13 de janeiro de 2005. Dispõe sobre a introdução do biodiesel na matriz energética brasileira. Diário Oficial da União, Brasília, DF, ano 142, n. 10, 14 jan. 2005. Seção 1, p.8-9.

. Tribunal de Contas da União. (2 $2^{\text {a }}$ Câmara). Acórdão no 2092/2010. Processo TC-007.606/2005-0. Sobre a condenação do senhor Sr. Aliomar da Rocha Soares, exPrefeito do Município de Morro do Chapéu/BA, em decorrência da omissão no dever de prestar contas relativas aos recursos repassados ao município por meio do Convênio 55195/98, objetivando promover o atendimento aos alunos matriculados na educação pré-escolar e no ensino fundamental das zonas urbana e rural com pelo menos uma refeição diária, à conta do PNAE (Programa Nacional de Alimentação Escolar). Diário Oficial da União, Brasília, DF, 20 mai. 2010. Seção 1, p. 116.

. Ministério da Integração Nacional. Plano Regional de Desenvolvimento do Nordeste. Recife: Sudene, 2011.

CANCLINI, N. G. Consumidores e cidadãos: conflitos multiculturais da globalização. 4. ed. Rio de Janeiro: Editora UFRJ, 1999.

CANDIDO, A. Os parceiros do Rio Bonito: estudo sobre o caipira paulista e a transformação dos seus meios de vida. 11. ed. Rio de Janeiro: Ouro sobre Azul, 2010. (1. ed.: 1964).

CASTELLS, M. A sociedade em rede: a Era da informação. Cheltenham: Edward Elgar, 2004.

CASTRO, I. E. O problema da escala. In: ; GOMES, P. C. C.; CORRÊA, R. L. (org.). Geografia: Conceitos e Temas. 14. ed. Rio de Janeiro: Bertrand Brasil, 2011. p. 117-140.

, I. E. Geografia e política: território, escalas de ação e instituições. Rio de Janeiro: Bertrand Brasil, 2005. 
, I. E. O Mito da necessidade: discurso e prática do regionalismo nordestino.

Rio de Janeiro: Bertrand Brasil, 1992.

CHAGAS, A. O Chefe Horácio de Matos. Salvador: EGBA, 1996.

CHAUÍ, M. Simulacro e poder. São Paulo: Fundação Perseu Abramo, 2006.

CHRISTOFFOLI, P. I. A luta pela terra e o desenvolvimento local. In: DOWBOR, L.; POCHMANN, M. (org.). Políticas para o desenvolvimento local. 1. ed. São Paulo: Fundação Perseu Abramo, 2010. p. 231-273.

CONFERÊNCIA NACIONAL DE BIOENERGIA, 2007, São Paulo. Bioenergia. COSTA, F. (org.). São Paulo: USP-CCS (Coordenadoria de Comunicação Social), 2008.

CORREARD, L. A. (2008a). Coopaf fecha contratos com Petrobras. Jornal Vanguarda, Morro do Chapéu, jan. 2008a, p. 1.

, L. A. (2008b). Coopaf fecha contrato com a Petrobras e renova com Brasil Ecodiesel. Jornal Coopaf, Morro do Chapéu, jan. 2008b, p. 1.

COSTA, W. M. O Estado e as políticas territoriais no Brasil. 3. ed. São Paulo: Contexto, 1991.

W. M. Geografia Política e Geopolítica: Discursos sobre o Território e o Poder. 2. ed. 1. reimpr. São Paulo: Editora da Universidade de São Paulo, 2008.

W. M. O Brasil e a América do Sul: cenários geopolíticos e os desafios da integração. Confins Online. França-Brasil, out. 2009. Disponível em:

$<$ http://confins.revues.org/6107>. Acesso em: 16 dez. 2011.

CUNEGUNDES, J. Morro do Chapéu. Salvador: Edição do autor, 1981.

DIEGUES, A. C.; ARRUDA, R. S. V. Saberes tradicionais e biodiversidade no

Brasil. Brasília: Ministério do Meio Ambiente; São Paulo: USP, 2001. 
FACÓ, R. Cangaceiros e fanáticos: gênese e lutas. 7. ed. Rio de Janeiro: Civilização Brasileira, 1983.

FARIAS, B. Produtos Orgânicos têm mercado até no exterior: morango da Chapada. Jornal A Tarde, Salvador, 20 set. 2001. Economia, p. 3.

FERNANDES, B. M. Movimentos socioterritoriais e movimentos socioespaciais. Revista NERA, Presidente Prudente, ano 8, n. 6, p. 14-34, jan./jun. 2005.

, B. M., MARQUES, M. I. M., SUZUKI, J. C. (orgs). Geografia agrária: teoria e poder. 1. ed. São Paulo: Expressão Popular, 2007.

, B. M.; WELCH, C. A.; GONÇALVES, E. C.; Agrofuel policies in Brazil: paradigmatic and territorial disputes. The Journal of Peasant Studies, London, v. 37, n. 4, p. 793-819, oct. 2010.

FERNANDES, F. Sociedade de classes e subdesenvolvimento. 5. ed. rev. São Paulo: Global, 2008.

FOUCAULT, M. Microfísica do poder. Rio de Janeiro: Edições Graal, 1979.

FURTADO, C. Seca e poder: Entrevista com Celso Furtado. São Paulo: Editora Fundação Perseu Abramo, 1998.

FREITAS (2011a), R. C. F. Fadada ao fracasso: Safra da mamona tem queda em 2011, mas este é apenas mais um capítulo na história de poucas vitórias dessa cultura no Brasil. Revista BiodieselBR, Curitiba, n. 25, p. 38-41, out./nov. 2011 a.

FREITAS (2011b), S. M. Programa Nacional de Produção de Uso de Biodiesel: a transição para um estilo de desenvolvimento sustentável. Textos para discussão. São Paulo: USP-IEA, n. 27, p.1-51, 2011 b.

GOMES, P. C. C. Geografia fin-de-siècle: O discurso sobre a ordem espacial do mundo e o fim das ilusões. In: CASTRO, I. E.; ; CORRÊA, R. L. (org.). Explorações geográficas: percursos no fim do século. Rio de Janeiro: Bertrand Brasil, 1997. p. 1342 . 
GOLDEMBERG, J.; VILlANUEVA, L. D. Energia, Meio Ambiente \&

Desenvolvimento. Tradução André Koch. 2. ed. rev. São Paulo: Editora da Universidade de São Paulo, 2003.

GOMES, M (Coord.). O Brasil dos agrocombustíveis: impactos das lavouras sobre a terra, o meio e a sociedade: soja e mamona. São Paulo: ONG Repórter Brasil, 2009. Disponível em:

$<\mathrm{http}$ :/www.reporterbrasil.org.br/documentos/o_brasil_dos_agrocombustiveis_v4.pdf $>$. Acesso em: 26 dez. 2011.

GUANZIROLI, C. E. Agronegócio no Brasil: perspectivas e limitações. Textos para discussão, Niterói: UFF/Economia, n. 186, p. 1-59, 2006.

C. E.; BUAINAIN, A. M.; DI SABBATO, A. Dez anos de evolução da agricultura familiar no Brasil: (1996 e 2006). Revista de Economia e Sociologia Rural, Piracicaba, v. 50, n. 2, abr./jun. 2012, p. 351-370.

HAESBAERT, R. C. O mito da desterritorialização: do "fim dos territórios" à multiterritorialidade. 3. ed. Rio de Janeiro: Bertrand Brasil, 2007.

HASHIZUME, Maurício. Cosan e mais 11 empregadores entram para a lista suja: Inclusão da gigante sucroalcooleira e de outros 11 empregadores envolvidos em casos de escravidão foi confirmada nesta quarta-feira (31) pela atualização semestral do cadastro mantido pelo MTE (Ministério do Trabalho e Emprego). São Paulo: ONG Repórter Brasil, 2009. Disponível em: $<$ http://reporterbrasil.org.br/2009/12/cosan-emais-11-empregadores-entram-para-a-quot-lista-suja-quot/>. Acesso em: 14 fev. 2013.

HESPANHOL, R. A. M. A adoção da perspectiva territorial nos projetos de desenvolvimento rural. Campo-território: Revista de Geografia Agrária, Uberlândia, v. 5, n. 10, 2010. p. 123-147.

INSTITUTO BRASILEIRO DE GEOGRAFIA E ESTATÍSTICA. Histórico de Várzea Nova. Disponível em:

$<$ http://biblioteca.ibge.gov.br/visualizacao/dtbs/bahia/varzeanova.pdf $>$. Acesso em: 18 out. 2012.

Histórico de Cafarnaum. Disponível em:

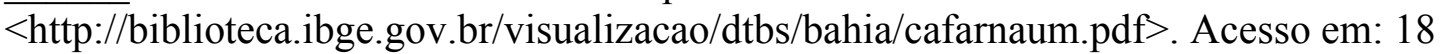
out. 2012.

LOPES, L. C. S. O Correio do Sertão e o fim do coronelismo em Morro do Chapéu.

Salvador: Núcleo de Estudos da História dos Impressos da Bahia, 2006. 
MASSEY, D. Um sentido global de lugar. In: ARANTES, O. (org.). O espaço da Diferença. Campinas: Papirus, 2000. Brasil, 2009.

, D. Pelo espaço: uma nova política da espacialidade. Rio de Janeiro: Bertrand

MARTINS, J. S. O vôo das andorinhas: Migrações temporárias no Brasil. In: Não há terra para plantar neste verão: o cerco das terras indígenas e das terras de trabalho no renascimento político do campo. 2. ed. Petrópolis: Vozes, 1988.

MEIHY, J. C. S. B.; HOLANDA, F. História Oral: como fazer, como pensar. São Paulo, Contexto, 2007.

MORAES, W. Jagunços e heróis: a civilização do diamante nas Lavras da Bahia. Rio de Janeiro: Civilização Brasileira, 1963.

MORAES, A. C. R. Bases da Formação Territorial do Brasil: o território colonial brasileiro no "longo" século XVI. São Paulo: Hucitec, 2000.

MORENDE, V. N. Fazendo política no sertão baiano. Centro de Mídia Independente, Brasil, 15 out. 2008. Disponível em:

$<$ http://www.midiaindependente.org/pt/red/2008/10/430881.shtml?comment=on>. Acesso em: 25 dez. 2012.

NEVES, D. P. Agricultura familiar: quantos ancoradouros! In: Geografia agrária: teoria e poder. FERNADES, B. M., MARQUES, M. I. M., SUZUKI, J. C. (orgs.). 1. ed. São Paulo: Expressão Popular, 2007.

NYE, J. Compreender os conflitos internacionais: Uma Introdução à Teoria e à História. 3. ed. Lisboa: Gradiva, 2002.

NOGUEIRA, L. A. H. Biocombustíveis na América Latina. São Paulo: Fundação Memorial da América Latina, 2007.

OLIVEIRA, F. Aproximações ao enigma: o que quer dizer desenvolvimento local? São Paulo: Pólis; Programa Gestão Pública e Cidadania/EAESP/FGV, 2001. 
OLIVEIRA, P. G. Contas da Coopaf são aprovadas por unanimidade na Assembléia Geral. Jornal Correio do Sertão, Morro do Chapéu, n. 3.060, p. 4, 15 jun. 2011.

Cobertura da assembleia da cooperativa.

PAGANINI, S. Combate à fome nas grandes cidades. In: Segurança Alimentar: um desafio para acabar com a fome no Brasil. ROCHA, M. (org.). 1. ed. São Paulo: Editora Fundação Perseu Abramo, 2004. (Coleção Cadernos da Fundação Perseu Abramo)

PEIXOTO, A. M. Enciclopédia Agrícola Brasileira. São Paulo: Editora da Universidade de São Paulo, 2002. v. 4.

PEREIRA, M. F. V.; KAHIL, S. P. A lógica corporativa do uso do território em Rondônia: o agronegócio da soja na região de Vilhena. In: Campo-Território: Revista de Geografia Agrária, Uberlândia, v.5, n.10, p. 288-311, ago.2010.

PINTO, L. C. G. O Programa de Compra de Alimentos da Agricultura. In: Segurança Alimentar: um desafio para acabar com a fome no Brasil. ROCHA, M. 1. ed. São Paulo: Editora Fundação Perseu Abramo, 2004. (Coleção Cadernos da Fundação Perseu Abramo)

POLACK, M. Memória e Identidade Social. In: Estudos Históricos, vol. 5, n. 10, 1992, p. $200-212$.

QUEIROZ, C. O. O sertão que eu conheci. Salvador: Fundação Cultural do Estado da Bahia, 1985.

RAFFESTIN, C. Por uma geografia do poder. São Paulo: Ática, 1993.

RICARDO, J. Presidente inaugura a maior fábrica de biodiesel das Américas. Jornal Coopaf, Morro do Chapéu, 25 fev. 2007, p. 1.

RIBEIRO, D. O povo brasileiro: a formação e o sentido do Brasil. 1. ed. 6 reimp. São Paulo: Companhia das Letras, 2006. (Companhia de Bolso)

ROCHA, A. J. D. Programas Levantamentos Geológicos Básicos do Brasil: Morro do Chapéu. Brasília: CPRM, 1997.

A. J. D.; PEDREIRA, A. J. Projeto Geoparques: Geoparque Morro do Chapéu (BA) (Proposta). Brasília: CPRM, 2009. Disponível em: 
$<$ http://www.cprm.gov.br/geoecoturismo/geoparques/morrodochapeu/informacoesadici onais.html>. Acesso em: 23/04/2012.

RODRIGUES, E. Nota de retificação de matéria relacionada ao Deputado Federal José Carlos Araújo. Chapada Online, Morro do Chapéu, 10 nov. 2011. Disponível em: $<$ http://www.chapadaonline.com/plantao/nota-de-retificacao-de-materia-relacionada-aodeputado-federal-jose-carlos-araujo>. Acesso em: 25 dez. 2012.

RODRIGUES, R. A. et al. Relatório Final do Grupo de Trabalho Interministerial encarregado de apresentar estudos sobre a viabilidade de utilização de óleo vegetal: biodiesel como fonte alternativa de energia. Brasília: Casa Civil, 2003.

SAMPAIO, M. O. O coronel negro: coronelismo e poder no norte da Chapada Diamantina. Jacobina: Uneb, 2009.

SANTOS, J. A. Estrutura de custos de produção de mamona: estudo de caso da região de Irecê/BA. Piracicaba: Universidade de São Paulo, 2009.

SANTOS, M. A natureza do Espaço: Técnica e Tempo, Razão e Emoção. 4. ed. 5. reimpr. São Paulo: Editora da Universidade de São Paulo, 2009.

, M. Por uma Geografia Nova: da Crítica da Geografia a uma Geografia Crítica. 6 ed. 1 reimpr. São Paulo: Editora da Universidade de São Paulo, 2008.

, M. Da Totalidade ao Lugar. 1. ed. 1. reimpr. São Paulo: Editora da Universidade de São Paulo, 2008.

, M. Espaço e Método. São Paulo: Nobel, 1985.

SECRETARIADO ESTADUAL DO PCDOB. PCdoB se posiciona sobre a saída de Edson Pimenta. Portal Vermelho, São Paulo, 15 abr. 2011. Disponível em: $<$ http://www.vermelho.org.br/ba/noticia.php?id_secao=58\&id_noticia=152067\&sms_ss $=$ blogger\&at_xt=4da8ef7f92ec5c5e\%2C0>. Acesso em: $11 \mathrm{dez} .2012$.

SILVA, J. G. Abertura do Seminário Nacional de Segurança Alimentar e Nutricional do Partido dos Trabalhadores. In: Segurança Alimentar: um desafio para acabar com a fome no Brasil. ROCHA, M. (org.). 1. ed. São Paulo: Editora Fundação Perseu Abramo, 2004. (Coleção Cadernos da Fundação Perseu Abramo) 
, J. G.; TAKAGI, M. Fome Zero: Política Pública e Cidadania. In: Segurança

Alimentar: um desafio para acabar com a fome no Brasil. ROCHA, M. (org.). 1. ed. São Paulo: Editora Fundação Perseu Abramo, 2004. (Coleção Cadernos da Fundação Perseu Abramo)

SOUZA, M. J. L. O território: sobre espaço e poder, autonomia e desenvolvimento. In: CASTRO, I. E., GOMES, P. C. C.; CORREAA, R. L. (org.). Geografia: Conceitos e Temas. 14. ed. Rio de Janeiro: Bertrand Brasil, 2011, p. 77-116.

SUZUKI, J. C. Modernização, território e relação campo-cidade: Uma outra leitura da modernização da agricultura. Agrária, São Paulo, n.6, p.83-95, 2007.

WANDERLEY, M. N. B. Raízes históricas do campesinato brasileiro. In: Encontro Anual da ANPOCS, 20., 1996, Caxambu. Anais... Caxambu: ANPOCS, 1996.

Disponível em: <comunidades.mda.gov.br/o/899445>. Acesso em: 23 out. 2012.

M. N. B. Agricultura familiar e campesinato: rupturas e continuidade. Estudos Sociedade e Agricultura, Rio de Janeiro, n. 21, outubro, 2003, p. 42-61.

WILKINSON, J. A agricultura familiar ante o novo padrão de competitividade do sistema agroalimentar na América Latina. In: Estudos Sociedade e Agricultura, Rio de Janeiro, n. 21, out. 2003, p. 62-87.

WOORTMANN, E.; WOORTMANN, K. O trabalho da terra: a lógica e a simbólica da lavoura camponesa. Brasília: Editora da UnB, 1997. 


\section{Mapas:}

BAHIA (Estado), Secretaria de Meio Ambiente e Recursos Hídricos. Território de Identidade: Bahia. Salvador: Coordenação de monitoramento ambiental e geoprocessamento, 2007. 74,72 $\mathrm{cm} \mathrm{x} \mathrm{89,1} \mathrm{cm.} \mathrm{Escala:} \mathrm{1:1.500.000}$

BRASIL, Ministério dos Transportes. Mapa Rodoviário: Bahia. Brasília: Departamento Nacional de Infraestrutura de Transportes, 2002. 98,4 cm x 68,5 cm. Escala: 1:1.700.000

ROCHA, A. J. D.; COSTA, I. V. G. (1995a). Projeto Morro do Chapéu: Mapa de Infra-Estrutura e Pontos Turísticos. Salvador: Superintendência Regional do CPRM, 1995a. 69,5 cm x 86,5 cm. Escala: 1:200.000.

(1995b). Projeto Morro do Chapéu: Mapa Planimétrico. Salvador: Superintendência Regional do CPRM, 1995b. 69,5 cm x 86,5 cm. Escala: 1:200.000.

(1995c). Projeto Morro do Chapéu: Mapa de Capacidade de Uso das Terras. Salvador: Superintendência Regional do CPRM, 1995c. 69,5 cm x 86,5 cm. Escala: $1: 200.000$.

(1995d). Projeto Morro do Chapéu: Mapa de Temperatura/Pluviometria. Salvador: Superintendência Regional do CPRM, 1995d. 69,5 cm x 86,5 cm. Escala: $1: 200.000$. 